
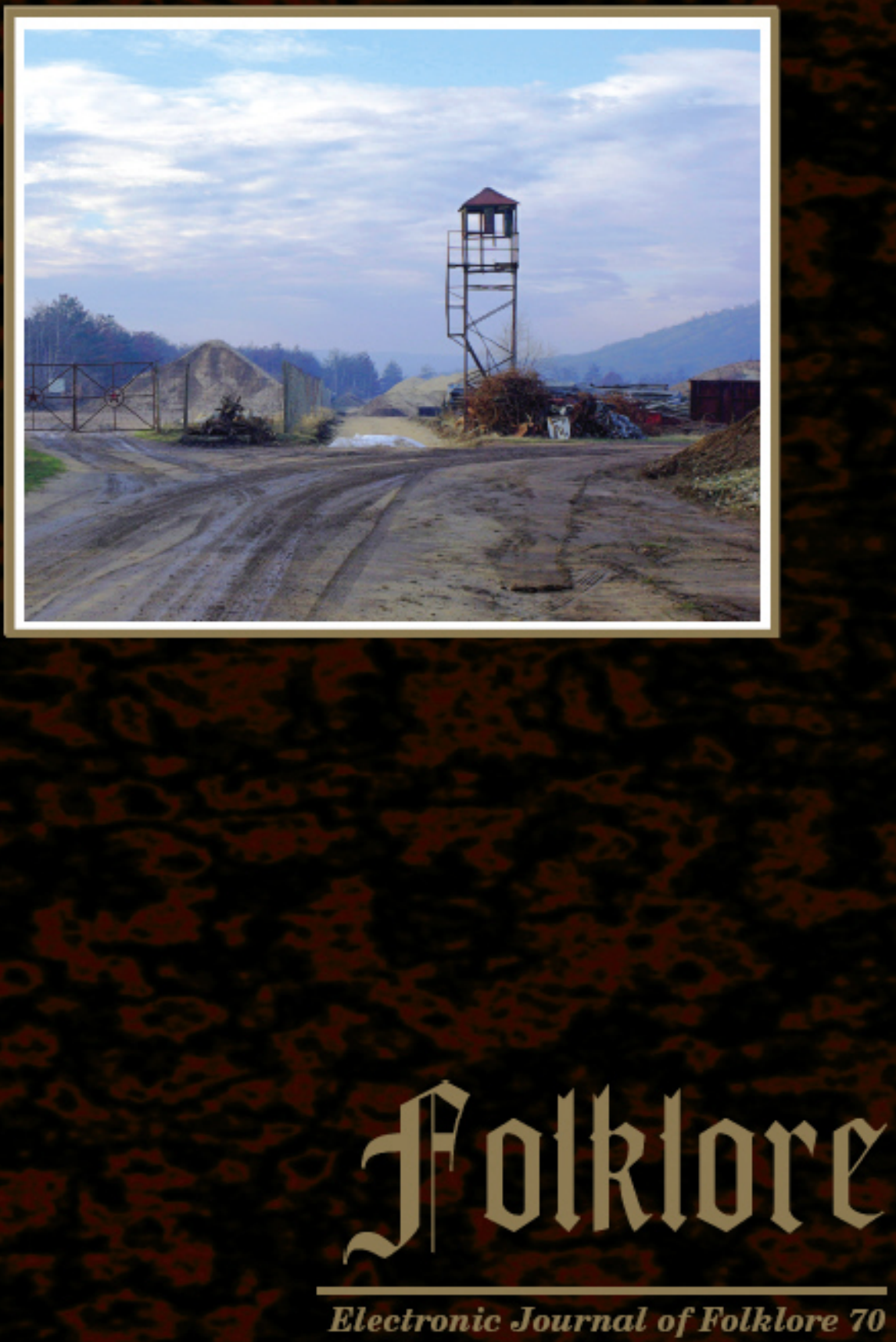


\section{Folklore}

Electronic Journal of Folklore

http://www.folklore.ee/folklore Printed version

Vol. 70

2017 
Folk Belief and Media Group

of the Estonian Literary Museum

Estonian Institute of Folklore

\section{Folklore}

Electronic Journal of Folklore

Vol. 70

Edited by Mare Kõiva \& Andres Kuperjanov

Guest editors: Elo-Hanna Seljamaa,

Dominika Czarnecka, Dagnosław Demski

ELM Scholarly Press

Tartu 2017 


$\begin{array}{ll}\text { Editor in chief } & \text { Mare Kõiva } \\ \text { Co-editor } & \text { Andres Kuperjanov } \\ \text { Guest editors } & \text { Elo-Hanna Seljamaa, Dominika Czarnecka, } \\ & \text { Dagnosław Demski } \\ \text { Copy editor } & \text { Tiina Mällo } \\ \text { Language editor } & \text { Richard Adang } \\ \text { News and reviews } & \text { Piret Voolaid } \\ \text { Design } & \text { Andres Kuperjanov } \\ \text { Layout } & \text { Diana Kahre }\end{array}$

Editorial board 2015-2020: Dan Ben-Amos (University of Pennsylvania, USA), Larisa Fialkova (University of Haifa, Israel), Diane Goldstein (Indiana University, USA), Terry Gunnell (University of Iceland), Jawaharlal Handoo (University of Mysore, India), Frank Korom (Boston University, USA), Jurij Fikfak (Institute of Slovenian Ethnology), Ülo Valk (University of Tartu, Estonia), Wolfgang Mieder (University of Vermont, USA), Irina Sedakova (Russian Academy of Sciences).

The journal is supported by the Estonian Ministry of Education and Research (IUT 22-5), the European Union through the European Regional Development Fund (Centre of Excellence in Estonian Studies), the state programme project EKKM14-344, and the Estonian Literary Museum.

This special issue was supported through baseline funding for the Estonian National Sciences (project: Belonging in Estonia from a Folkloristic Performance Studies Perspective) and the Estonian Research Council (Institutional Research Project “Tradition, Creativity and Society: Minorities and Alternative Discourses” IUT2-43).

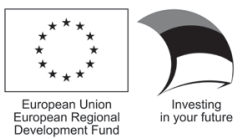

Indexed in EBSCO Publishing Humanities International Complete, Thomson Reuters Arts \& Humanities Citation Index, MLA International Bibliography, Ulrich's Periodicals Directory, Internationale Volkskundliche Bibliographie / International Folklore Bibliography / Bibliographie Internationale d'Ethnologie, Open Folklore, C.E.E.O.L., Scopus

\section{Editorial address:}

Folklore: Electronic Journal of Folklore

Vanemuise 42-235

51003 Tartu

Estonia

phone: $\quad+3727377740$

fax: $\quad+3727377706$

e-mail: folklore@folklore.ee

home page: http://www.folklore.ee/folklore

All rights reserved

(C) Estonian Literary Museum

Estonian Institute of Folklore

Authors

Design Andres Kuperjanov

According to Creative Commons licence BY-NC-ND 4.0

ISSN 1406-0957

doi:10.7592/FEJF2017.70 


\section{CONTENTS}

"Small Places, Large Issues": Between Military Space and

Post-Military Place

Elo-Hanna Seljamaa, Dominika Czarnecka, Dagnosław Demski

After the End of "Little Moscow": Memories, (Re)Construction, and Appropriation of Space in Wünsdorf

Christoph Lorke

German Democratic Republic of the 1970s-1980s

through the Eyes of Soviet Officers (Oral Stories)

Evgeny V. Volkov

"Invisible Places, Hidden History": The Role of the Former

"Russian Airport" in Telling Stories about the Front

in the South Vértes Region

István Sántha

Life with Soviet Troops in Czechoslovakia and after

Their Withdrawal

Prokop Tomek

The "Degraded" Landscape of a Post-Soviet Military Base

121

in Poland: Outside vs. Inside View

Dominika Czarnecka

Mārciena - between Legacy and Nostalgia

Ilze Boldāne-Zeḷenkova

Values, Substantiality, and Passage of Time: Representations and

Reinterpretations of Military Heritage

Dagnosław Demski

From the Borderland of the Iron Curtain to European and

World Cultural Heritage

Melinda Harlov-Csortán 


\section{Discussion}

Contemporary Transformations of Ethnology/Anthropology

in Russia: An Invitation to Further Discussion

Dmitriy Funk, Irina Nam

\section{In Memoriam}

Christie Davies

News IN BRIEF

The 29th International Society For Humor Studies Conference in Montreal, Canada.

Piret Voolaid, Liisi Laineste

Nikolai Anisimov Defended His Doctoral Thesis on the Udmurts' Birth and Burial

Customs. Aado Lintrop

Book Reviews

Contemporary Legends in Slovenia. Saša Babič

Still Ecological Migration? An Ewenki Case. Dmitriy Funk, Seil Djanyzakova

An Anthropology of Outer Space: Planetary Imagination and Placemaking 


\title{
"SMALL PLACES, LARGE ISSUES": BETWEEN MILITARY SPACE AND POST-MILITARY PLACE
}

\author{
Elo-Hanna Seljamaa \\ Department of Estonian and Comparative Folklore \\ University of Tartu, Estonia \\ e-mail: elo-hanna.seljamaa@ut.ee
}

\section{Dominika Czarnecka}

Institute of Archaeology and Ethnology

Polish Academy of Sciences, Poland

e-mail:d.czarnecka@hotmail.com

\section{Dagnostaw Demski}

Institute of Archaeology and Ethnology

Polish Academy of Sciences, Poland

e-mail:d.demski2@gmail.com

The exploration of the complicated cultural and social landscapes of post-Cold War military bases in Central and Eastern Europe (CEE), offered by this special issue of Folklore: Electronic Journal of Folklore, has its starting point in Borne Sulinowo in the north-western part of Poland. In the 1930s, this one-time German fishing and farming village became a military training area of the Third Reich and later, during World War II, a transitory camp and then a prison camp for officers. Following the takeover by the Red Army in 1945, the whole area was turned into a "closed city": a secret military settlement that constituted one node in the intricate web of military objects woven by the Soviet Union across the CEE during the Cold War years. Borne Sulinowo, the Polish civilian town, has been in the making since the departure of the military forces of the Russian Federation from Poland in 1993 (Demski \& Czarnecka 2015; Czarnecka 2015).

Characterised by layers of military presence inscribed on the built environment and instilled in local lore, Borne Sulinowo captures many of the conundrums facing former Soviet/Russian ${ }^{1}$ military bases and their civilian neighbours or inhabitants. As a result, it is exceptionally suited to host and inspire comparative research on this topic. The articles presented in this special 
issue build on presentations delivered during a seminar in Borne Sulinowo in May 2016, ${ }^{2}$ which was dedicated to post-Cold War military zones and brought together scholars from Visegrád countries, Baltic states, Germany, and the Russian Federation.

The cultural anthropologists, folklorists, (military) historians, and researchers of cultural heritage involved in this project share an interest in lived realities of post-Cold War military spaces as they emerge from resources mined in archives and created by means of ethnographic fieldwork methods. The participants' diverse disciplinary backgrounds testify to the complexity of the phenomenon under scrutiny, as well as to its growing relevance in academia and beyond. ${ }^{3}$ Rather than going into the specifics of political history or chronicling the presence of Soviet/Russian troops in the entire region, ${ }^{4}$ contributions to this special issue concern individuals and local communities caught in the Cold War, in transformations initiated by the fall of the Iron Curtain ${ }^{5}$ and the subsequent withdrawal of the Russian Federation forces from the CEE.

Borrowing from Thomas Hylland Eriksen (2009), this special issue focuses on people living in "small places", in which both in the past and at present "large issues" have taken place and continue to unfold, shaping, though not determining, life and meaning making on the ground. The empirical data presented and analysed in this volume come from the Czech Republic (article by Prokop Tomek), Germany (Christoph Lorke), Hungary (Melinda Harlov-Csortán and István Sántha), Latvia (Ilze Boldāne-Zeḷenkova), Poland (Dominika Czarnecka and Dagnosław Demski), and the Russian Federation (Evgeny V. Volkov). Much of it concerns everyday life in private, familial or communal settings influenced by the presence of the Soviet/Russian military or by memories and material traces of this presence. Often absent from state-level memory politics, this quotidian "stuff" points to the bias of public, officially endorsed discourses about the past. ${ }^{6}$ While it cannot be erased from peoples' memories or from landscapes, it also cannot be easily included in the narratives of resistance and collective victimhood that most CEE countries have been telling about themselves since the end of the Cold War. Approached from this angle, civilians' intimate familiarity with Soviet/Russian military presence can be said to constitute "negative heritage" (Meskell 2002), "difficult heritage" (Macdonald 2009) or a legacy (Noyes 2016): a past or a marker of a past that is problematic, threatens the present, but is also meaningful and cannot be "killed off" (Noyes 2016: 388), at least not easily (cf. Tunbridge \& Ashworth 1995 on "dissonant heritage").

By approaching (post-)Cold War military bases from the perspective of the everyday, this special issue seeks to contribute to a more nuanced and diversified understanding of the nature and effects of the Soviet/Russian military presence in the CEE, and how this period and remnants thereof have been 
and could be recycled and mobilised for new purposes; how the Cold War as it was lived east of the Iron Curtain is remembered and narrated under the present circumstances, which are both radically different and unsettlingly similar. Several military objects erected by the Soviet Union in its sphere of influence during the Cold War years have been recently returned to military use, modernised and enlarged in response to the altered international security situation. ${ }^{7}$ Revamping former Soviet/Russian infrastructure for NATO allies protecting the CEE states from the unpredictable behaviour of the Russian Federation may come across as an ironic twist of history, yet it also testifies to the importance of trying to understand the Cold War and its consequences from multiple perspectives.

Before turning to recurrent themes and insights emerging from contributions to this special issue, a brief overview is offered of Soviet/Russian troops' presence in and withdrawal from the CEE.

\section{FROM THE ESTABLISHMENT OF MILITARY PRESENCE TO THE WITHDRAWAL OF TROOPS}

Following World War II, the Soviet Union created four military formations or groups of forces in its sphere of influence, which corresponded to military districts within the USSR. The largest and best equipped peacetime administrative unit of this kind was located in the German Democratic Republic and underwent several name changes: established in 1945 as the Group of Soviet Occupation Forces in Germany, it was renamed the Group of Soviet Forces in Germany in 1954, and the Western Group of Forces in 1988 (see articles by Lorke and Volkov in this issue). The boundaries of the Northern Group of Forces (1945-1993) overlapped the Polish borders (Czarnecka and Demski in this issue), while the Southern Group of Forces was stationed first in Romania and Bulgaria (1945-1947), and later in Hungary (1957-1992) (Sántha and HarlovCsortán in this issue). The first Central Group of Forces (1945-1955) was based in Austria and Hungary until the former regained independent status in 1955 (Harlov-Csortán in this issue). The second Central Group was formed in 1968 in Czechoslovakia (Tomek in this issue).

It is obvious from these dates and the changing locations of the formations that besides counterbalancing the armed forces on the western side of the Iron Curtain, these formations were instrumental in keeping the satellite states in check and suppressing democratisation processes in the region. ${ }^{8}$ This is witnessed by the fact that no Soviet troops were stationed in Czechoslovakia until the 1968 Prague Spring (Tomek in this issue). 
The Baltic states and their inhabitants were in a different situation, belonging as they did to the Soviet Union rather than its sphere of interest and influence. ${ }^{9}$ The Baltic Military District, with headquarters in Riga, was formed as early as 1940, after the Soviet annexation of Lithuania, Latvia, and Estonia (Beyrle 1996; on Latvia, see Boldāne-Zel,enkova in this issue). In case of a potential conflict with the West, forces located in the Baltics could be redeployed quickly to Poland and Germany (Golon 1999: 54; Laaneots 2015).

The dynamic grid of Soviet military objects in the CEE took shape gradually. While some objects were built from scratch, many larger bases utilised the infrastructure erected by tsarist Russia in the 18th and 19th centuries or by the Third Reich before and during World War II, or infrastructure built under the Habsburg Empire. The objects could assume the form of closed towns, sectioned-off town districts or single objects, and varied in their significance and level of specialisation, constituting extensive multilevel structures at both national and supranational levels.

While the establishment and functioning of Soviet military bases was a "large issue", which shaped local landscape and influenced the life of people living in "small places", so was the departure of troops. More often than not, long, complicated, and tense negotiations preceded and accompanied the withdrawal (Beyrle 1996). The Central Group of Forces pulled out of the Czech territory in 1990-1991 (Tomek in this issue). The withdrawal of the Western Group of Forces from Germany constituted the largest relocation of Russian troops ever during peacetime and consequently took several years, from 1991 to 1994 (Lorke and Volkov in this issue). The departure of the Northern Group of Forces from Poland began in 1991 and was completed in 1993 (Czarnecka in this issue). The process of withdrawing the soldiers of the Southern Group of Forces from Hungary, initiated in 1989, ended in 1991 (Sántha and Harlov-Csortán in this issue; Bowers 1991: 61).

More so than in Central Europe, the Russian Federation sought excuses to prolong its military presence in the newly independent Baltic states, especially in Latvia and Estonia, where the withdrawal of troops was tangled up with issues of citizenship, as well as other legislation concerning the large Russianspeaking population residing in these countries. While the withdrawal of troops from Lithuania was completed by August 31, 1993, it took a year longer in Latvia and Estonia. Moreover, some strategically important military objects remained under the control of and inhabited by the Russian military until 1995 in Estonia and until 1999 in Latvia (Trei 2015 and Boldāne-Zeḷenkova in this issue, respectively). Both countries also agreed to give permanent residence permits and social guarantees to military pensioners (see Kadak 2015: 68, and Jundzis 2014: 12-13). ${ }^{10}$ 


\section{MAKING SENSE AND USE OF WHAT WAS LEFT}

The withdrawal of Russian troops from the CEE brought about an unprecedented demilitarisation of land and property. Abandoned training areas and formerly crowded garrisons turned into ghost towns evoke their extraordinary, indeed, extraterritorial, status in the past, as do the costly, often feeble topdown attempts to integrate this infrastructure into the surrounding civilian life. Success stories seem to be rare and to hinge on the availability of affordable housing, public services and transport connections to nearby bigger centres with better employment opportunities, as is demonstrated by Wünsdorf and Milovice, the former headquarters of Soviet/Russian troops in Germany and Czechoslovakia, respectively (Lorke and Tomek in this issue).

The cases of Ralsko in the Czech Republic and Mārciena in Latvia, examined here by Tomek and Boldāne-Zeḷenkova, show how former Soviet military bases can become symbols of emptying countryside. Deserted apartment blocks and communal buildings in the middle of nowhere emerge as indexes of the end of the Cold War and of the failure of communism. Local residents who remember rural life as it used to be, however, may view these same structures as signifiers of the failure of capitalism and the nation-state, and give way to nostalgia for bygone days (Boldāne-Zel̦enkova in this issue; cf. Dzenovska 2011).

The destruction of the Iron Curtain and the break-up of the Soviet Union prompted groups and individuals alike to reinvent themselves. For Soviet/Russian servicemen stationed in the CEE, the collapse of the USSR meant not only many practical and economic difficulties but also a decline in their social status (Volkov in this issue). The same holds true for many Russian-speakers in the Baltic states, as well as for those individuals and communities throughout the CEE who had lived in symbiosis with foreign troops and profited from their presence (see, for example, Lorke, Boldāne-Zel̦enkova, and Sántha in this issue).

One of the recurring, if not overarching, themes in this volume is the efforts by both individuals and collectives to make sense of the local past and of themselves in the flow of time against the backdrop of national narratives that tend to be built on the negation and condemnation of the socialist era. From the point of view of states that lost their independence or full control over their internal matters and territory to the Soviet Union, the Soviet/Russian military presence and its consequences serve as painful and sometimes also shameful reminders of events that should not have happened. The experiences and memories of the inhabitants of "small places" are more diverse and particular, sometimes also self-contradictory, and expressing them serves functions different than the large narratives forged by nation-states. 
Almost every "small place" explored in this special issue is characterised by a multi-layered military presence, containing elements and traces left behind by the armies of different powers, waves of settlements and in many cases (see the contributions by Czarnecka, Demski, Harlov-Csortán, and Tomek) also by changing national borders. The multi-layered character of the military presence on the former Soviet/Russian bases is revealed not only in the built environment and ruins but also in locals' memories and narratives of displacement, deportations, unwanted neighbours, and acts of violence. However, there also are stories of illicit trafficking in fuel, vegetables, and other goods, attending cultural events, and shopping in well-equipped army stores. Objects associated with the Soviet military, such as the "Russian airport" in the Hungarian region of South Vértes, analysed by Sántha, can serve as mnemonic devices or points of references that generations of narrators use to recount their own lives or those of others and to comment upon other, more distant or recent events that they associate with World War II and interactions with foreign soldiers.

More often than not, interactions and encounters between the military and local civilians crossed - and sometimes transgressed - ethnic and ethno-cultural boundaries, and entangled relationships between ethnically marked military and civilian realms form another recurrent theme in contributions to this special issue (see, in particular, the articles by Lorke, Volkov, Czarnecka, Demski, Sántha, and Tomek; cf. Satjukow 2005). When discussing official and organised, as well as spontaneous and private, occasions for inter-ethnic and inter-cultural communication, it is important to include the perspective of Russian/Soviet servicemen stationed in the CEE: their perceptions of these encounters, of their mission in the CEE, and of the places they were forced to leave (Volkov in this issue). Online networks and archives created by former servicemen and their family members, a topic touched upon by both Boldāne-Zelenkova and Lorke, open different windows through which to explore Cold War military bases in the CEE, the military's interactions with the local population and landscapes, and the void created by their departure.

\section{THE (BROKEN?) PROMISES OF TOURISM}

In the present era of "experience economy" (Pine \& Gilmore 1999), tourism is often presented as the means for maintaining life in peripheral rural areas. Many of the post-military landscapes are rich in natural beauty and rare species. The decades-long presence of the Soviet/Russian military in the CEE caused serious ecological damage, the assessment and elimination of which could only begin after the withdrawal of troops, but it also contributed to nature conser- 
vation by means of creating "green belts" or large territories closed off from ordinary utilisation of land and natural resources (see contributions to Sepp 2011). This paradox of simultaneous purity and contamination seems to have played a role in making post-military landscapes susceptible to diametrically opposed interpretations motivated by particular goals. While lakes and forests attracted settlers to Borne Sulinowo in the early 1990s, national media and the political elite constructed this area as a degraded landscape hazardous to human beings. This image of Borne Sulinowo as a place damaged by Soviet/ Russian troops helped to legitimise the new regime, while also serving the business interests of competing tourist destinations (Czarnecka in this issue).

Vast military training areas are used for paintball, treasure hunts, races of military vehicles, reenactments, and other bodily and sensory activities tourists can immerse themselves in (Tomek and Lorke in this issue; see also Pohunek 2015). Former military bases and other objects have become destinations for tourists interested in particular historical eras or events, architecture, industrial heritage or in military history in general (see Demski in this issue). Inhabitants of former Soviet/Russian garrisons face the dilemma of how to renovate and modernise the built environment around them, while striving to preserve the original military features and aesthetics that attract tourists.

While tourism is a source of income for some, it directly or indirectly influences everybody's life, making it less comfortable and contributing to selfmusealisation (Pickering \& Westcott 2003: 4-5). Touristification is based on careful choices, not all of which are of the locals' making. Decisions to renovate certain buildings and not others are often made at the national level, in Brussels, in the offices of transnational banks or other places removed from "small places" and their inhabitants. Several contributors to this special issue (e.g. Harlov-Csortán and Boldāne-Zeḷenkova) draw attention to the tendency to prioritise the more distant, pre-socialist past at the expense of preserving military objects from the Cold War era. Depending on the context and point of view, this may indicate a refusal, failure or inability to touristify the intimate relationship to the Soviet/Russian military past. Submitting it to external examination requires distance. While this can be built up over time, is it desirable? For individuals or localities, at a national or international level, what is at stake in remembering or forgetting?

The contributions to this special issue suggest that the process of making sense of the Soviet/Russian military presence in, and its consequences for, "small places" and their inhabitants is very much an on-going process closely connected with national memory politics and various interpretations of past and current "large issues". What may be deemed shameful or painful and silenced, or overlooked at the national level, focused on generalisations, is 
conspicuously present at the local level and needs to be dealt with for successful self-identification to take place.

\section{NOTES}

1 When the Soviet Union ceased to exist in December 1991, it had a significant military presence in the CEE. Moreover, as contributions to this special issue demonstrate, "Soviet" and "Russian" were often perceived to be interchangeable categories in everyday parlance. The expression "Soviet/Russian" is used in the introduction in an effort to capture these complexities.

2 The Seminar on the Post-Cold War Military Zones in Central and Eastern Europe was held on May 26 and 27, 2016, in the Cultural and Educational Center in Borne Sulinowo. Organised by the Institute of Archaeology and Ethnology of the Polish Academy of Sciences in Warsaw, the Department of Estonian and Comparative Folklore at the University of Tartu, and the Museum Chamber of Borne Sulinowo, it was attended by fourteen scholars from eight CEE countries. See, e.g., http://www. gawex.pl/wiadomosci/wydarzenia/11347/W-Bornem-Sulinowie-naukowcy-debatowalio-powojennych-bazach-wojskowych, last accessed on November 27, 2017.

This special issue was supported through baseline funding for the Estonian National Sciences (project: Belonging in Estonia from a Folkloristic Performance Studies Perspective).

3 For example, see information about the 2018 conference Military and Post-Military Landscapes, organised by Czech scholars: http://www.historickageografie.cz/cechg2018, last accessed November 27, 2017.

4 Regarding Soviet/Russian troops' presence in and departure from various CEE countries, see, for example, Anušauskas 2015 (Lithuania), Haud 2015 (Estonia), Hoffmann \& Stoof 2013, and Kowalczuk \& Wolle 2010 (Germany), Krogulski 2001 (Poland), Pataki 2000 (Hungary), Pecka 1996a and 1996b (Czechoslovakia), Upmalis et al. 2006 (Latvia).

5 Until 1955, the Iron Curtain ran through the middle of Austria. After the Soviet forces withdrew from Austria, the Iron Curtain moved to the borders of Austria with Hungary, Czechoslovakia, and Yugoslavia.

6 Scholars engaged in memory studies have in recent years drawn attention to changes in the ways the period of late socialism (mid-1950s or 1960s to late 1980s) has come to be remembered and represented in autobiographical accounts, as well as various genres of popular culture, emphasising the emergence of the everyday as a point of entry into making sense of and representing the past (Jõesalu 2017; Koleva 2012; Klumbytė \& Sharafudtinova 2013 [2012]; Kõresaar 2016; Kruszyński \& Osiński 2016; see also the articles by Demski, Harlov-Csortán, and Volkov in this issue).

7 The annexation of Crimea by the Russian Federation in the early spring of 2014 in particular prompted NATO to take additional collective defence measures, including the deployment of multinational battle groups in the Baltic states and Poland. 
8 In this context it is necessary to mention the Warsaw Pact signed in Warsaw in 1955. The Warsaw Pact, which formed a reaction to the integration of West Germany into NATO in 1955, was a political and military alliance of the states forming the Eastern Bloc, with the dominant role played by the USSR. The Pact was to function for thirty years, but in 1985 it was extended for another twenty years. It was declared disbanded as of July 1, 1991. Army headquarters of individual member states were subject to the Tenth Directorate of the General Staff of the USSR Armed Forces, performing the role of the General Staff of the United Armed Forces, with headquarters in Moscow (Sowa 2011: 208).

9 One crucial difference that derived from this fact was that like other male citizens of the USSR, men from the Baltic republics were obliged to serve in the Soviet Army.

${ }^{10}$ While the withdrawal of foreign troops removed one obstacle from the Baltic states' path to NATO and the European Union, the Russian Federation has since developed a compatriot policy that both targets and instrumentalises Russian-speaking populations in the Baltics and beyond (Simonsen 2001; Conley \& Gerber 2011). Even though it has not led to noticeable organised movements of Russophones in Latvia and Estonia, transnational cultural ties between Russian-speaking residents of these countries and Russia seem to have grown stronger in recent years (Kallas 2016 and references therein). The renewed individual and collective significance attached by Estonian and Latvian Russophones to Victory Day on May 9, marking the end of World War II, and its emergence as a vernacular holiday celebrated in public rather than within family circles, as was the case in the 1990s, can be seen as evidence of this emergent phenomenon (see Boldāne-Zelenkova in this issue; Kaprāns \& Seljamaa 2017, as well as other contributions to Gabowitsch \& Gdaniec \& Makhotina 2017).

\section{REFERENCES}

Anušauskas, Arvydas (ed.) 2015. Lithuania in 1940-1991: The History of Occupied Lithuania. Vilnius: Genocide and Resistance Research Centre of Lithuania.

Beyrle, John R. 1996. Case Study: The Withdrawal of Russian Military Forces from the Baltic States. Washington: National War College. Available at http://www.dtic. mil/dtic/tr/fulltext/u2/a441390.pdf, last accessed on November 27, 2017.

Bowers, Stephen R. 1991. Hungary: Soviet Forces Out, New Policies In. Faculty Publications and Presentations. Paper 61. Available at http://digitalcommons. liberty.edu/gov_fac_pubs/61, last accessed on November 23, 2017.

Conley, Heather A. \& Gerber, Theodore P. 2011. A Report of the CSIS Europe Program. Russian Soft Power in the 21st Century: An Examination of Russian Compatriot Policy in Estonia. Washington: Center for Strategic \& International Studies. Available at https://csis-prod.s3.amazonaws.com/s3fs-public/legacy_files/files/ publication/110826_Conley_RussianSoftPower_Web.pdf, last accessed on November 27, 2017.

Czarnecka, Dominika 2015. Making Sense of the Past: (Re)constructing the Local Memorial Landscape in a Post-Soviet Base in Poland. Journal of Ethnology and Folkloristics, Vol. 9, No. 2, pp. 21-40. Available at http://www.jef.ee/index.php/ journal/article/view/204, last accessed on November 27, 2017. 
Demski, Dagnosław \& Czarnecka, Dominika 2015. Mapping Meanings in the Post-Soviet Landscape of Borne Sulinowo. Latvijas Vēstures Institūta Žurnāls, No. 2 (95), pp. 96-120. Available at http://www.lvi.lv/lv/LVIZ_2015_files/2numurs/D_ Demski_D_Czarnecka_Mapping_LVIZ_2015_2.pdf, last accessed on November 27, 2017.

Dzenovska, Dace 2011. Notes on Emptiness and the Importance of Maintaining Life. Anthropology of East Europe Review, Vol. 29, No. 2, pp. 228-241. Available at https://scholarworks.iu.edu/journals/index.php/aeer/article/view/1248/1337, last accessed on November 27, 2017.

Eriksen, Thomas H. 2009. Mate miejsca, wielkie sprawy: Wprowadzenie do antropologii spotecznej $i$ kulturowej. [Small Places, Large Issues: An Introduction to Social and Cultural Anthropology.] Warszawa: Oficyna Wydawnicza Volumen.

Gabowitsch, Mischa \& Gdaniec, Cordula \& Makhotina, Ekaterina (eds.) 2017. Kriegsgedenken als Event: Der 9. Mai 2015 im postsozialistischen Europa. Paderborn: Ferdinand Schöningh.

Golon, Mirosław 1999. Północna Grupa Wojsk Armii Radzieckiej w Polsce w latach 1945-1956: Okupant w roli sojusznika. [The Northern Group of Forces of the Soviet Army in Poland in the years 1945-1956: The Occupant as the Ally.] Czasy Nowożytne, Vol. 6, pp. 37-115. Available at http://bazhum.muzhp.pl/media//files/ Czasy_Nowozytne_periodyk_poswiecony_dziejom_polskim_i_powszechnym_ od_XV_do_XX_wieku/Czasy_Nowozytne_periodyk_poswiecony_dziejom_ polskim_i_powszechnym_od_XV_do_XX_wieku-r1999-t6/Czasy_Nowozytne_ periodyk_poswiecony_dziejom_polskim_i_powszechnym_od_XV_do_XX_wiekur1999-t6-s37-115/Czasy_Nowozytne_periodyk_poswiecony_dziejom_polskim_i_ powszechnym_od_XV_do_XX_wieku-r1999-t6-s37-115.pdf, last accessed on November 27, 2017.

Haud, Jaak (comp.) 2015. Vene vägede lahkumine Eestist. Nii nad läksid! [Withdrawal of Russian Troops from Estonia: So They Left!] Tallinn: Eesti Eruohvitseride Kogu.

Hoffmann, Hans-Albert \& Stoof, Siegfried 2013. Sowjetische Truppen in Deutschland und ihr Hauptquartier in Wünsdorf 1945-1994: Geschichte, Fakten, Hintergründe. Berlin: Köster.

Jõesalu, Kirsti 2017. Dynamics and Tensions of Remembrance in Post-Soviet Estonia: Late Socialism in the Making. Dissertationes Ethnologiae Universitatis Tartuensis 6. Tartu: University of Tartu Press. Available at http://dspace.ut.ee/ handle/10062/55781, last accessed on November 28, 2017.

Jundzis, Tālavs 2014. Krievijas karaspēka izvešana no Latvijas 1992-1994: Diplomātijas uzvara vai politiska piekāpšanās? [Removal of Russian Federation Armed Forces from Latvia: A Diplomatic Success or Political Concession?] Latvijas Zinātnuu Akadēmijas Vēstis, Section A, Vol. 68, No. 3-4, pp. 4-23. Available at http:// www.lza.lv/index.php?option=com_content\&task=view\&id=2263\&Itemid=400, last accessed on November 28, 2017.

Kadak, Jüri 2015. Nõukogude (Vene) vägede viibimise ja lahkumisega seotud probleemid, julgeolekualased riskid ja ohud Eesti Vabariigis aastatel 1944-1994. [The Problems, Security Risks, and Threats Connected to the Presence and Withdrawal of Soviet (Russian) Troops in the Estonian Republic 1944-1994.] In: Jaak Haud (comp.) Vene vägede lahkumine Eestist. Nii nad läksid! Tallinn: Eesti Eruohvitseride Kogu, pp. 49-70. 
Kallas, Kristina 2016. Claiming the Diaspora: Russia's Compatriot Policy and Its Reception by Estonian-Russian Population. Journal of Ethnopolitics and Minority Issues in Europe, Vol. 15, No. 3, pp. 1-25. Available at http://www. ecmi.de/fileadmin/downloads/publications/JEMIE/2016/Kallas.pdf, last accessed on November 28, 2017.

Kaprāns, Mārtiņš \& Seljamaa, Elo-Hanna 2017. Momentaufnahmen einer Erinnerungsgemeinschaft. Die Feiern am 9. Mai in Tallinn und Narva. In: Mischa Gabowitsch \& Cordula Gdaniec \& Ekaterina Makhotina (eds.) Kriegsgedenken als Event: Der 9. Mai 2015 im postsozialistischen Europa. Paderborn: Ferdinand Schöningh, pp. 172-202.

Klumbytè, Neringa \& Sharafudtinova, Gulnaz (eds.) 2013 [2012]. Soviet Society in the Era of Late Socialism, 1964-1985. Lanham: Lexington Books.

Koleva, Daniela (ed.) 2012. Negotiating Normality. Everyday Lives in Socialist Institutions. New Brunswick, NJ: Transaction Publishers.

Kõresaar, Ene (ed.) 2016. Baltic Socialism Remembered: Memory and Life Stories since 1989. Special issue of Journal of Baltic Studies, Vol. 47, No. 4. Available at http:// www.tandfonline.com/toc/rbal20/47/4, last accessed on November 28, 2017.

Kowalczuk, Ilko-Sascha \& Wolle, Stefan 2010. Roter Stern über Deutschland: Sowjetische Truppen in der DDR. Berlin: Links.

Krogulski, Mariusz L. 2001. Okupacja w imię sojuszu: Armia Radziecka w Polsce 19561993. [Occupation in the Name of Alliance: The Soviet Army in Poland 1956-1993.] Warszawa: Wydawnictwo von Borowiecky.

Kruszyński, Marcin \& Osiński, Tomasz (eds.) 2016. Szkice o codzienności PRL. [Sketches About Everyday PPR.] Lublin: IPN.

Laaneots, Ants 2015. Vene väed Baltikumis ja Eestis 1990-92. [Russian Forces in the Baltic States and in Estonia 1990-92.] In: Jaak Haud (comp.) Vene vägede lahkumine Eestist. Nii nad läksid! Tallinn: Eesti Eruohvitseride Kogu, pp. 195-203.

Macdonald, Sharon 2009. Difficult Heritage: Negotiating the Nazi Past in Nuremberg and Beyond. Abington \& New York: Routledge.

Meskell, Lynn 2002. Negative Heritage and Past Mastering in Archaeology. Anthropological Quarterly, Vol. 75, No. 3, pp. 557-574. Available at https:// www.jstor.org/stable/3318204?seq=1\#page_scan_tab_contents, last accessed on November 28, 2017.

Noyes, Dorothy 2016. Heritage, Legacy, Zombie: How to Bury the Undead Past. In: Dorothy Noyes. Humble Theory: Folklore's Grasp on Social Life. Bloomington \& Indianapolis: Indiana University Press, pp. 371-409. Available at https://muse. jhu.edu/book/49082, last accessed on November 28, 2017.

Pataki, István 2000. A Magyarországon állomásozó szovjet csapatok létszáma, állomáshelyei és teljes kivonása. [The Number, Positions, and Total Withdrawal of Soviet Troops Stationed in Hungary.] Múltunk, Vol. 45, No. 2, pp. 222-252.

Pecka, Jindřich 1996a. Odsun sovětských vojsk z Československa 1989-1991: Dokumenty. [Transfer of Soviet Forces from Czechoslovakia 1989-1991: Documents.] Prague: Ústav pro soudobé dějiny Akademie věd ČR.

Pecka, Jindřich 1996b. Sovětská armáda v Československu 1968-1991: Chronologický prehled. [Soviet Army in Czechoslovakia 1968-1991: Chronological Overview.] Prague: Ústav pro soudobé dějiny Akademie věd ČR. 
Pickering, Paul A. \& Westcott, Robyn 2003. Monuments and Commemorations: A Consideration. Humanities Research, Vol. 10, No. 2, pp. 1-8. Available at https://www.researchgate.net/publication/237207105_Monuments_and_ commemorations_A_consideration, last accessed on November 28, 2017.

Pine, B. Joseph II \& Gilmore, James H. 1999. The Experience Economy. Work Is Theatre \& Every Business a Stage: Goods and Services Are No Longer Enough. Boston, Massachusetts: Harvard Business School Press.

Pohunek, Jan 2015. Odraz archeologizovaných krajinných prvků $v$ etnografických pramenech. [Reflection of Archaeologized Landscape Elements in Ethnographic Resources.] Diss. (PhD Thesis). Univerzita Karlova. Available at http://www. academia.edu/31086650/Odraz_archeologizovan\%C3\%BDch_krajinn\%C3\%BDch prvk\%C5\%AF_v_etnografick\%C3\%BDch_pramenech, last accessed on November 28, 2017.

Satjukow, Silke (ed.) 2005. 'Die Russen kommen!' Erinnerungen an sowjetische Soldaten 1945-1992. Erfurt: Landeszentrale für politische Bildung Thüringen.

Sepp, Kalev (ed.) 2011. The Estonian Green Belt. Tallinn: The Estonian University of Life Sciences. Available at http://citeseerx.ist.psu.edu/viewdoc/download?doi=10 .1.1.465.5277\&rep=rep1\&type=pdf, last accessed on November 28, 2017.

Simonsen, Sven Gunnar 2001. Compatriot Games: Explaining the 'Diaspora Linkage' in Russia's Military Withdrawal from the Baltic States. Europe-Asia Studies, Vol. 53, No. 5, pp. 771-791. Available at https://www.jstor.org/stable/826369?seq=1\#page_ scan_tab_contents, last accessed on November 28, 2017.

Sowa, Andrzej L. 2011. Historia polityczna Polski 1944-1991. [Political History of Poland 1944-1991.] Kraków: Wydawnictwo Literackie.

Trei, Jüri 2015. Paldiski endise allveelaevnike õppekeskuse tuumaobjekti üleandmine Eestile. [Handing Over to Estonia of the Nuclear Object of the Former Submarine Training Facility in Paldiski.] In: Jaak Haud (comp.) Vene vägede lahkumine Eestist. Nii nad läksid! Tallinn: Eesti Eruohvitseride Kogu, pp. 119-120.

Tunbridge, J. E. \& Ashworth, Gregory J. 1995. Dissonant Heritage: The Management of the Past as a Resource in Conflict. Chichester \& New York: John Wiley.

Upmalis, Ilgonis \& Tilgass, Ēriks \& Dinevičs, Jānis \& Gorbunovs, Anatolijs 2006. Latvija - PSRS karabāze. 1939-1998: materiāli un dokumenti par Padomju armijas atrašanos Latvijā un tās izvešanu. [Latvia - the USSR Military Base. 1939-1998: Materials and Documents on the Presence of the Soviet Army in Latvia and Its Withdrawal.] Riga: Zelta grauds. 


\title{
AFTER THE END OF "LITTLE MOSCOW": MEMORIES, (RE)CONSTRUCTION, AND APPROPRIATION OF SPACE IN WÜNSDORF
}

\author{
Christoph Lorke \\ Department of History \\ Westfälische Wilhelms University, Münster, Germany \\ e-mail: christoph.lorke@uni-muenster.de
}

\begin{abstract}
This article focuses on the context and lasting consequences of the withdrawal of the Russian troops from the small town of Wünsdorf in East Germany (Brandenburg region) in 1994. The headquarters of the high command of the Soviet forces in Germany had been located in Wünsdorf since 1954. The locals lived in close proximity to the Russians. In the German Democratic Republic, the (limited) real and imagined encounters, interactions, and perceptions of the "other" were highly determined by traditional images, and were most likely influenced by the tabooed official discourse of "occupiers" vs. "friends". This ambivalent potpourri of different memorial dimensions has strongly shaped negotiations of the past and remembrance of the transition period (1989/1990-1994), as well as of the post-Soviet/Russian phase up to the present. By analyzing individual and collective modes of handling a problematic and highly conflictual military force, as well as the German Democratic Republic's past, different ways of (re)constructing and appropriating the post-military space become apparent.
\end{abstract}

Keywords: Cold War, German Democratic Republic's past, German reunification, identity, (contested) memory, military heritage, otherness, space

On August 31, 1994, Matvei Prokopevich Burlakov, the last Commander-inChief of the Group of Soviet Forces in Germany, reported to President Boris Yeltsin: "The intergovernmental treaty regarding the conditions of the temporary residence of Russian troops and the withdrawal modalities are fulfilled.... Today was the last day of the past" (König 2010). According to Article 4 of the "Two Plus Four Treaty" "Treaty on the Final Settlement with Respect to Germany", September 12, 1990), the Soviet Union was obliged to withdraw its troops stationed in East Germany within four years, i.e. by the end of 1994. On August 31, the largest relocation of troops during peacetime in history, which brought about an unprecedented demilitarization of land and property, was realized four months earlier than originally planned. The Western Group of 
Forces ${ }^{1}$ was considered an elite unit of the Soviet Army and included 550,000 people, of whom 380,000 were members of the army and 170,000 were civilians (among whom there were 90,000 children). The troops were based in more than one thousand locations all over East Germany. The country was considered an immensely important geostrategic, military, and, not least, symbolic-political forward post, located right on the Iron Curtain. ${ }^{2}$ There were many important military bases, ${ }^{3}$ and many of them ${ }^{4}$ in the immediate vicinity of East Berlin. One of the main reasons for this military cordon was to be ready to quell potential riots, as happened when the Group of Soviet Forces in Germany helped suppress the Uprising of 1953 in East Germany (Fig. 1).

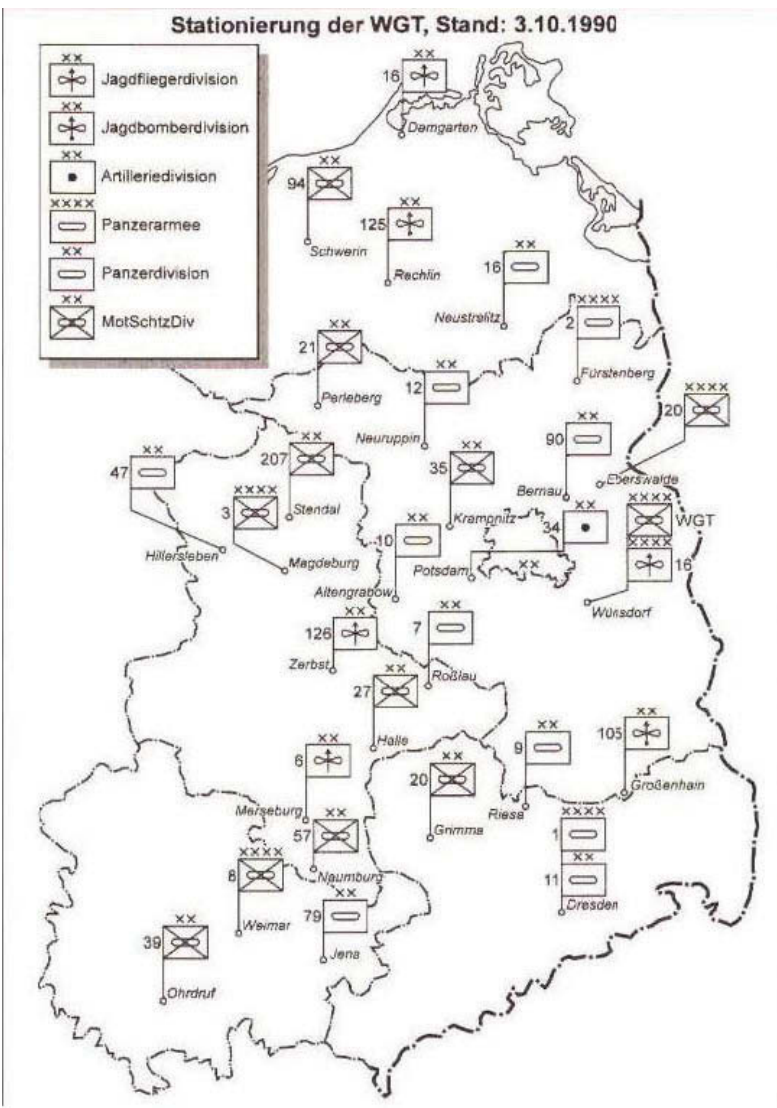

Figure 1. Western Group of Forces in the German Democratic Republic, October 3, 1990 (Naumann 1996 [1993]: 345). 
Figure 2. General Matvei P. Burlakov and Manfred Stolpe. Wünsdorf, June 11, 1994 (Gehrke 2008: 74).

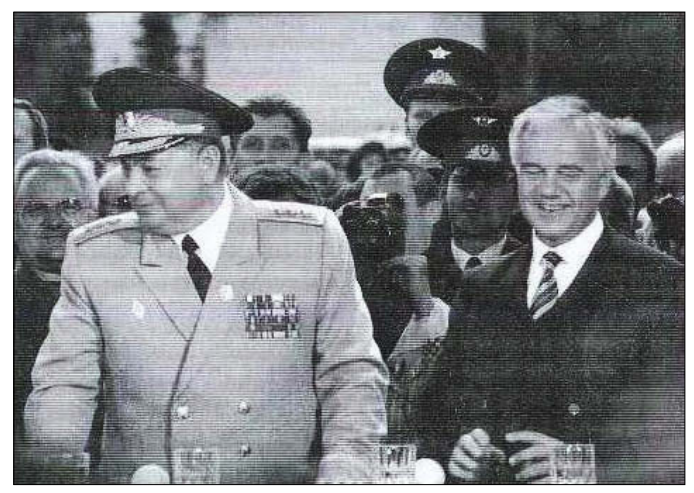

By far, the largest number of troops were based in Wünsdorf. Since 1954 the headquarters of the high command of the Soviet Forces in Germany had been situated in this small town, less than fifty kilometers south of Berlin. Wünsdorf was a divided - military and civilian - location during the Cold War. The figures vary, but it can be assumed that between 40,000 and 70,000 soldiers and civilians were living and working there. Thus, the place was an immensely important strategic outpost and, because of its location close to the Cold War's geographical border, the Western Group of Forces were regarded as the "chosen ones", "the proud and favorite children" of the entire Soviet Army. ${ }^{5}$

When the last soldiers left in 1994, a 600-hectare area with tens of thousands of rounds of ammunition and explosive ordnance remained, including almost 680 buildings, 45,000 cubic meters of rubbish, waste oil, paint, chemicals, batteries, used tires, and asbestos, as well as 404 cats, twenty-six dogs, one goat, and one wild sheep (Kaiser \& Herrmann 2010 [1993]: 199-200). In the common parlance of the locals, the military area of Wünsdorf was generally known as "Little Moskwa" or the "Forbidden City" (Verbotene Stadt). With few exceptions, natives were not allowed to enter this zone and the whole settlement, including the daily life of the Soviet families, was taboo. Nevertheless, living in close proximity led to the fact that the Russians were omnipresent in the daily lives of the German residents before the transition period (1989-1994). The result was the emergence of conflictual situations and memories, which - as has been discussed regarding other examples of Soviet military bases in the German Democratic Republic (GDR) - have often lasted until the present time (e.g. von Wrochem 2003). As a consequence, noteworthy tensions between the collective and communicative memory, on the one side, and the public commemorative culture, on the other, could be observed (for definitions of the collective and communicative memory, see Assmann 1997 [1992]; Welzer 2002; Erll 2005). By far the largest base of Soviet/Russian soldiers prior to 1994, the military 
district of Wünsdorf appeared in many respects to be a "non-place", with its distorted, inconclusive relationship between history and identity (Augé 1992).

This article discusses the memorial dimension of the Soviet/Russian past in Wünsdorf, as well as the symbolic (re-)construction and the collective and individual appropriation of this particular space after the Soviet/Russian withdrawal in 1994. By analyzing hegemonic forms of public (primarily involving politics and the media) and individual remembrance of the "foreign" Soviet/ Russian past within the (post-)socialist GDR society (Obertreis \& Stephan 2009), the social, discursive, and symbolic (re-)shaping of space and its symbolic (pre-)determination can be illustrated (Assmann 2009; Keller 2016). Focusing on these aspects, Wünsdorf exemplifies double-layered, closely intertwined negotiations with a conflictual "problematic" past with regard to 1) the GDR as a whole and 2) the Soviet/Russian occupiers as "foreign" forces. This contribution deals with the different modes of managing conflictual and dissonant heritage in the individual and broader political and public dimensions (Tunbridge \& Ashworth 1996; for the relation between cultural heritage and war, see Sörensen \& Viejo-Rose 2015) by focusing on the following questions: how did the long-standing presence of the "foreign" shape the remembrance of Wünsdorf's recent past? How do certain layers of memory interact with each other? What kind of "master narratives" of that time were (and are) dominant, and why? How can German and Russian perspectives be integrated when dealing with the still "smoking" past (Tuchman 1964)?

To answer these questions, I analyzed research, scholarly and popular publications on the matter, and media narratives since 1990. Furthermore, in spring and summer 2016, I conducted twenty interviews with German contemporary witnesses. I contacted the interview participants through a press call that was distributed via local media. ${ }^{6}$ The call explicitly asked for witnesses who remembered not only the process of withdrawal but also the time before. Thus, most of the interviewees were - and, in most cases, still are - local residents. The guided telephone interviews usually lasted one or two hours. ${ }^{7}$ The oldest interviewee was born in 1929, and the youngest in 1954. This range allowed for further insights regarding the relationship between generations and space, ${ }^{8}$ its different symbolic constructions, performances, and acquisitions, as well as the generational temporalization of the space in question (Grothusen 2014). Significantly, nineteen of the twenty people who answered the call were male; this obvious gender imbalance requires explanation (Leydesdorff 1996). It seems that the topic of (military) history and its aftermath is much more interesting for men. Due to traditional, dualistic gender stereotypes and corresponding attributions regarding "male" and "female" spheres of interest and awareness, it is also possible that men consider themselves "more important" and "more 
competent" witnesses of this time period. The tabooed topic of rape also may have influenced the willingness of people to answer the call (von Wrochem 2003: 67-68). ${ }^{9}$ Thus, the "voluntary" aspect of the call significantly distorted the sample. However, this article does not claim to be a representative survey, but rather a glimpse into the widely encountered patterns of memory and their presence today. Therefore, a gendered perspective on the story is built into the study. After a quick glance at the military history of Wünsdorf in the twentieth century, the paper discusses the circumstances and forms of remembrance of the process of withdrawal from today's perspective. In the last chapter, I will outline the most common ways of dealing with the Soviet/Russian past in the context of the "conversion" after 1994.

\section{FROM WÜNSDORF TO ВЮНСДОРФ AND BACK: A GARRISON TOWN AND ITS MILITARY HERITAGE}

The history of Wünsdorf as a military site is suspenseful, as well as full of fractures and new beginnings (for an overview, see Kaiser 1998). Wünsdorf was a small village with less than 900 inhabitants when an Infantry School was opened in 1910. During World War I the first mosque on German territory was built there at the request of the Office for Foreign Affairs, when a camp for prisoners of war was opened in Wünsdorf. The "Half Moon Camp" housed up to at least 15,000 Muslim prisoners of war until 1918, mainly Tatars, Indians, Moroccans, Algerians, and Senegalese. After the end of the war, the camp served as a shelter for Russian emigrants, mostly Muslim Tatars, many of whom had decided not to go back to their home country. The camp was finally closed in 1922 and the mosque was torn down two years later because of dilapidation (Abdullah 1984: 18-20; Höpp 1997). During the Third Reich, the area served as a military gymnastics school, and was used as a training camp for athletes to prepare for the Olympic Games in Berlin in 1936. There was an enormous barracks area, a military training area, and a firing range. Beginning in 1938, the headquarters of the Supreme Command of the Armed Forces (Oberkommando der Wehrmacht) was situated in Wünsdorf. On April 20, 1945, the area was occupied by Soviet troops; the command staff and Marshal Georgy Zhukov stayed there during the final battle of Berlin. Beginning in 1946, the area was used by the 1st Belorussian Front.

In February 1954, the place became the headquarters of the High Command of the Soviet Forces in Germany, and the Soviet military housing rapidly expanded: 175 local families, 800 people in total, had to leave their houses, apartments, and property, and were resettled to make way for the Soviet Army 
and its personnel (Kaiser \& Herrmann 2010 [1993]: 138). Elderly citizens still remember this time as a deep disruption of their personal mobility and lives. ${ }^{10}$ At this point, the highway $\mathrm{F} 96^{11}$ - by then the longest highway within the GDR and the most important direct connection to its capital, Berlin - was closed to transit traffic until 1994, dividing Wünsdorf into two. Ordinary people who did not have authorized transit permission (propusk) had to make a laborious detour of more than ten kilometers (Fig. 3).

Henceforth, the military area was closed to GDR civilians, and even the Socialist Unity Party of Germany's (Sozialistische Einheitspartei Deutschlands, SED) ruling elite was not allowed to enter until 1960, when Willi Stoph, the then Minister of National Defense and subsequently Deputy Prime Minister of the GDR (1964-1973), paid a visit to the troops. Most GDR citizens were not aware of the existence, size, and importance of Wünsdorf as a military site and a control center of the Soviet Army during the Cold War. From there not only was armored protection organized during the construction of the Berlin Wall under Marshal Ivan Konev, but also aviation security for the entire GDR airspace was guaranteed. Both the suppression of the Prague Spring in 1968 and the change in the GDR government in 1971, when Walter Ulbricht was replaced by Erich Honecker as the General Secretary of the Central Committee of the ruling

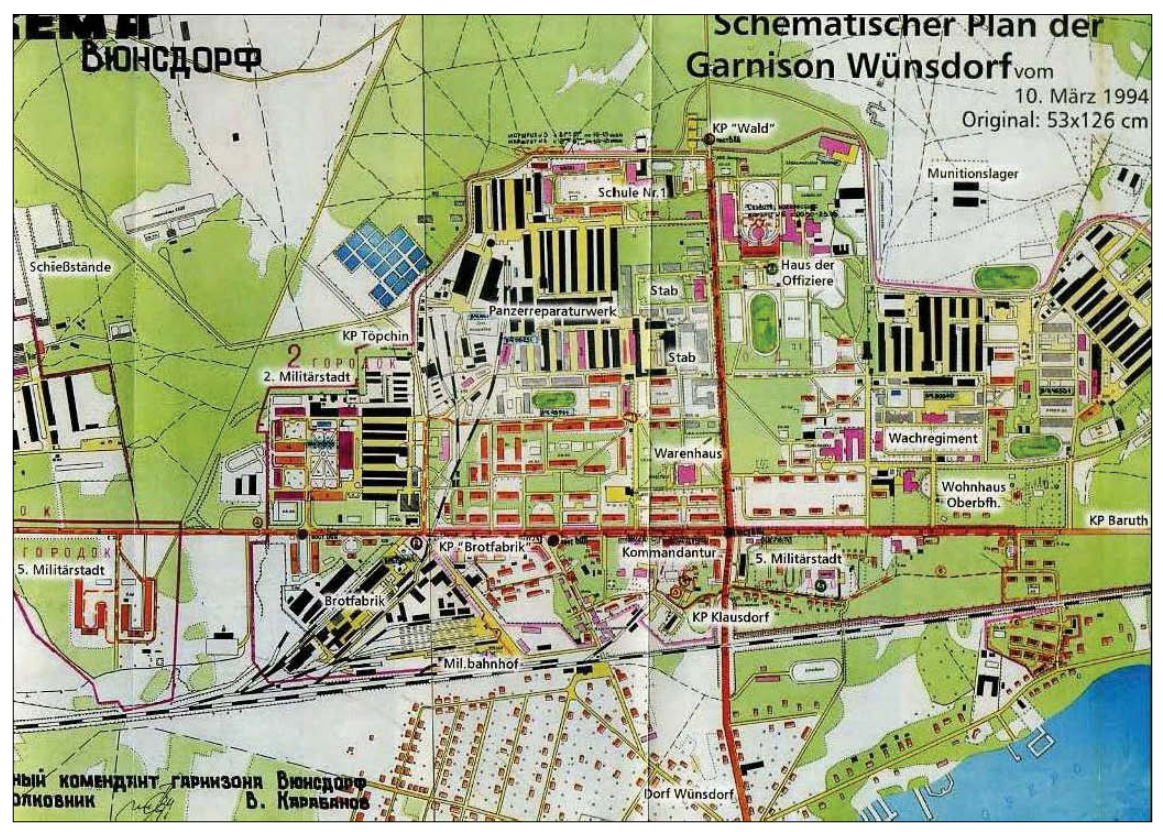

Figure 3. Map of Wünsdorf. Garnisonsmuseum Wünsdorf, March 10, 1994. 
party, were coordinated and commanded from Wünsdorf. Doubtless, this place could be regarded as the fist of Soviet policy in the GDR (Kowalczuk \& Wolle 2010: 126; for the circumstances of the occupation, see Satjukow 2008; for the broader context, see Loth 1998). There was a daily military train to Moscow for Soviet soldiers and their families at 8 pm every evening, which departed from what was called Russen-Bahnhof ('Russians' Station').

The closed doors of the "Forbidden City" - also a popular term to describe other Soviet military places in the GDR, such as Hillersleben, Neuruppin, Naumburg, and Weimar - stimulated speculation, and not only in regard to the quantity of troops and civilians stationed in Wünsdorf, which was a proper city with schools and kindergartens, medical care, a theater, sport facilities, and its own hairdressers and shops. In this context, the ideologically justified and politically imposed "friendship" between the occupants and the natives was full of suspense and was decisively influenced by 1) the former ideas of the highly ideologically and racially connoted image of the "Bolsheviks" and 2) the perception of the Russenkasernen ('Russian barracks') in daily life. As the historian Silke Satjukow asserted (2004: 237-240; 2005; 2009: 57-58), many residents did not perceive the barracks as places of safety, but rather of unpredictability and hidden danger due to unpleasant noises and odors, incoming and outgoing tanks and helicopters, damage along public roads or agricultural areas, explosions, aviation noises and resulting impairments. Furthermore, because of traffic accidents, "unnatural deaths", brawls in restaurants, robberies, and sexual attacks, the barracks became places of danger and foreignness (Behrends 2003; Müller 2011: 163-189). This refers to specific modes of inclusion, exclusion, and fixation of the "foreign" within a certain space, in this case the "Forbidden City" (with reference to Georg Simmel: Geenen 2002: 223-239).

On the other hand, the forbidden zone also had considerable appeal, which the Wünsdorf locals experienced notably in the area of consumption. It is significant that almost half of the interviewees mentioned several aspects which referred to a well-functioning partnership of convenience, especially in later decades. The special Russenmagazine ('Russians' stores') sold many sought-after products. Party functionaries and a few people who were working within the restricted area were holders of propusks, entry tickets into the restricted area, and they described how they benefited from certain privileges. Popular, but usually very rare products, such as building materials, Czech beer, Hungarian ham, tropical fruits, tinned fish, confections, and even smoked eels from the Baltic sea were sold, and thus represented another dimension of encountering the "foreign": culinary delights and accouterments. In retrospect, such ex-post constructed imagined behavior patterns could obviously also evoke the aftertaste of unjustified, "conspicuous consumption" (Veblen 1899), which is very evident in 
the example of Gerhard Dombritz (born in 1942). He was a local political activist in the 1990s and described himself as "not a Russian whisperer". Dombritz stated, "more by hearsay than by personal experience", that, in his memory, the lifestyle of the officers was exorbitant. Furthermore, the high-ranking officers' food and supplies were even "more snobbish"12 than in the secure housing zone for leading functionaries in Wandlitz, about thirty kilometers northeast of Berlin. Senior party members of the Socialist Unity Party of Germany lived there; the area remained off-limits to ordinary East Germans until 1990.

This statement illustrates that, in terms of more than boarding and lodging, the interviewees remember a massive discrepancy between German and Soviet higher ranks. In addition, the differences and prosperity gaps between the military ranks - and thus, inevitably, between the locals and the lower ranks - were also immense. Hence, there was self-ghettoization of the Soviet troops, which was not surprising since it helped to limit the soldiers' "Western experience", especially with regard to consumption. In the eyes of many ordinary Soviet soldiers and in comparison with their own situation after the end of World War II, the Germans lived "off the fat of the land" (Satjukow 2004: 225-249). Thus, rigorous spatial isolation, poor accommodations, low salaries, strict regulations regarding contact with the locals, and prohibitions against fraternization were implemented by the military administration, as those seemed to be the safest means of avoiding disciplinary violations (Bassistow 1994: 46-48).

However, in the case of Wünsdorf, as everywhere else, German-Soviet contact could never be prevented entirely, exceeding the usual scope of highly formalized, prepared and stage-managed official encounters, and not only because of the approximately 1,000 Germans who worked in the garrison at the end of the GDR; instead, "friendships" or "friendly relations" - terms frequently used in the interviews - and even a few love affairs developed. Nonetheless, the Waffenbrüderschaft ('comrades-in-arms') were, just like everywhere else in the GDR, apparently limited to the officer corps (Müller 2005: 128-132). While the lower ranks lived in comparatively meager accommodations - although flush toilets, washbasins, and showers were not standard in the Soviet Army - service in the GDR forces was particularly advantageous for officers and generals: between 800 and 1,000 marks per month, a family allowance of up to 250 marks, and a significantly better range of products available. Four or five years in the GDR forces made it possible to procure goods and clothes, and even to save some money. In short, service in Wünsdorf was regarded as an honor for the "favored few" Soviet Army soldiers, in particular in terms of living standard (Bassistow 1994: 49-50; Kaiser \& Herrmann 2010: 144). For the locals, the image of Wünsdorf was strongly marked by the presence of soldiers. Hence, they resigned themselves to living in a city of "occupiers"; for many, living 
with the Russians became a part of the everyday routine, eventually not only in Wünsdorf, but in other Soviet military bases, too. This routine was suddenly and unexpectedly shaken by the fall of the Berlin Wall in the autumn of 1989.

\section{TIMES OF CHANGES, TIMES OF UNCERTAINTY: THE INTERIM PHASE, THE WITHDRAWAL, OLD AND NEW CONFLICTS}

In many respects, the early 1990s in reunified Germany can be characterized as a transition period, although the break was usually much more abrupt and intense for East Germans than for West Germans (Danyel 2015). The presence (and later, withdrawal) of the Russian troops is one of the many different, overlying, and partially interwoven passages between the "old" and the "new". After the fall of the Berlin Wall and the reunification of Germany in October 1990, the Russian military command initially regarded the desire of many Germans for unity, freedom, and sovereignty as ingratitude. Little by little, understanding grew, while at the same time concerns increased with regard to the period after the withdrawal. Uncertainty and psychological stress among the soldiers increased (Arlt 1998: 619).

The majority of the East Germans, however, welcomed the withdrawal as a "second" or even "real liberation", since now there was a way to express longrepressed sentiments. Sensationalist press articles and simple stigmatizations supported a shift in liability, a deflection of responsibility regarding the failures and the end of the GDR, which served as mental exculpation. The Russians, who were previously praised, were in this emotionally charged phase defamed as "uncivilized occupiers" (Satjukow 2009: 62) and thus represented the "other", anti-civilization, now in contrast to the West. Emphasizing a narrative of wild upheaval, the media landscape was full of lurid articles dealing with crime, corruption, and immorality, half-barbaric behavior, a shadow economy, mafia-type actions, bribes, the flourishing "black market", drug trafficking, unexplained murders, and contract killings. The "flogging" of all manner of things - including food, cars, and guns - from which both the Russian and (West and East) German traders had benefited, was one of the main topoi. Wünsdorf was especially pointed out as an important trading center. Other sensationalist comments involved the Russians' lax handling of environmental problems. ${ }^{13}$ By appealing - both intentionally and unintentionally - to anti-Soviet prejudices and feelings, these media narratives enjoyed great popularity among the reunified German public.

These discourses seem to have strongly influenced, shaped, and strengthened individual perceptions and imaginations. The same applies to the debates about 
the GDR as a "Stasi state" or Unrechtsstaat ('illegitimate state'), which for many East Germans involved a symbolic general devaluation of their biographies and overlapped with the discourses regarding the Russians (for an overview, see Großbölting 2010; Kollmorgen 2010; Sabrow 2012). After 1990, opinions and prejudices regarding the Russians, which had been taboo due to the propagandaimposed glorification of the Soviets as heroic liberators, were able to emerge directly. It seems that very soon after 1990 many East Germans - and thus, of course, Wünsdorf locals - regarded the Russians as a complementary element of the new society, which helped to strengthen a new specific, occasionally ostentatious, and confidently performed East German sense of unity (Satjukow 2009: 65). In contrast, others saw the derogatory judgments regarding the Russians as personal attacks on themselves. Provided this brief sketch of a conflictual and contested scenario, many Wünsdorf residents remember feeling joy and relief, as well as compassion and uncertainty, when the Russian troops left. Probably because they knew that the end of the transition period was near and, at the same time, recognizing the importance of the armed forces to the local economy, they felt a certain empathy with the soldiers. Local businessmen in particular were even very sad, as Günther Heisig (born in 1933), at that time the owner of a shoe store, remembered..$^{14}$

From a source-critical point of view, personal statements about the "Soviet occupiers" involved problems: whether the statements served as a subsequent smoothing, or reflected actually existing sentiments, varied from individual to individual. Quite a few respondents' descriptions of their experiences with Soviets/Russians were most probably affected by contemporary stereotypes or their opinions on present-day Russia. However, in Wünsdorf - as in many other military bases in East Germany - concerns about the remaining soldiers did arise, and with alarming openness. There were occasional demands, such as "Civilian Russians Go Home", "Leave, Russian Parasites" or, as residents painted in Cyrillic on the road to the department store: "Get Out, You Bastards". ${ }^{15}$ The environmental damage - in the end, a cost borne by the Federal Republic of Germany - in all likelihood strengthened such negative sentiments.

According to Arnold Klein (born in 1954), who felt melancholy after the withdrawal, thefts and vandalism were the order of the day, ${ }^{16}$ and even physical assaults targeting soldiers and their families were observed. Even though these were only scattered incidents, these years were characterized by wildness, confusion, and a new form of uncertainty. Ilse Bollman, who had worked for more than twenty years inside the "restricted zone", said with regard to crime and the attacks: "During this period, you could trust no one - neither Russians nor Germans". ${ }^{17}$ Both Winfried Bläse (born in 1950) and Bernhard Michel stated that after the withdrawal, Wünsdorf was dead, an utter ghost 
town. ${ }^{18}$ When the rising unemployment and the closing of businesses became more evident - after the initial phase of euphoria and relief - very quickly an atmosphere of disillusionment and uncertainty developed among many locals. They considered the period after 1994 a standstill or even a decline, and thus mourned in many respects the passing of the good old days. ${ }^{19}$ It is obvious that the assessments of those days were highly linked to the respective individual's perception and valuation of the Soviet/Russian troops.

A closer look at the "other" side reveals further insights: for the Russian soldiers, the shift was apparently even more radical. The psychological effects of the ideological collapse and the instability in their home regions, and the pronounced feeling of being unwanted and unwelcome guests undermined selfconfidence: for many of the soldiers, withdrawal meant social decline. They felt like "beaten winners", as the last Minister-President of the GDR, Lothar de Maizière, stated in Moscow in spring 1990. Due to the insecure future, a significant proportion - according to estimates, up to one-third - of all returned families split up (Locke 2014).

Another serious problem was the slow process of the housing program. Despite the eight-billion-mark support by the Federal Government, there were significant delays. Although 45,000 apartments were built in Russia, Ukraine, and Belarus between 1992 and 1996, 50,000 families had no suitable housing after their return (Foertsch 1994: 125-127). Preparing for their withdrawal, many soldiers bought household appliances, technological items, or second-hand cars in order to sell them in Russia. There were rumors of secret arms sales according to recent surveys, 81,000 tons of ammunition went unaccounted for (Kaiser \& Herrmann 2010 [1993]: 184) - and Kalashnikov for used car swaps (e.g. Liebold 1991). "Taking everything that was not nailed down" was a phrase often mentioned in the interviews. In contrast, Heinz Bremer (born in 1936), who generally pleaded for an "objective analysis" of those developments, expressed an explicit warning against a derogatory attitude toward the situation, especially by those who did not know the actual living conditions in their home countries very well. ${ }^{20}$

The official farewell celebration, which was initiated and orchestrated by the Russian commanders, was intended to symbolize the departure of Russian troops from all of Germany, and to make people forget any negative feelings. Thus, the narrative Heimkehr / Abschied in Würde ('Leave in Dignity') was established in bilateral contracts after 1990 in order to express caution, gentleness, and tact (Burlakov 1994; Foertsch 1994; Nawrocki 1994; Abschied in Würde 1994). However, even though the withdrawal was performed in a calm, formal atmosphere that could be considered a "logistical tour de force" (Gießmann 1992: 177-209; Kaiser \& Herrmann 2010: 182; for a meticulous chronological 


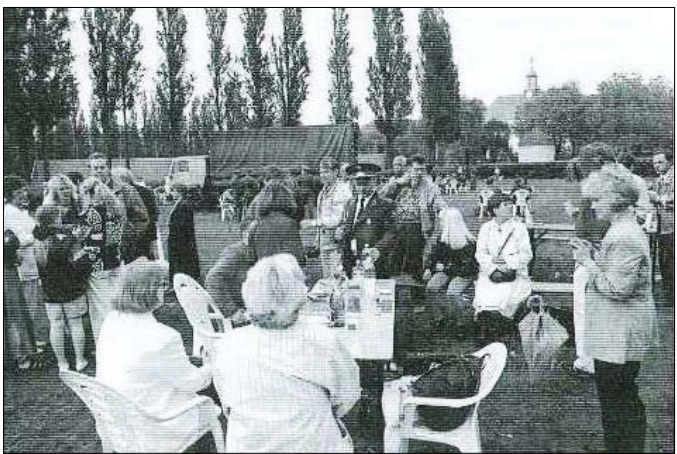

Figure 4. Open house in Wünsdorf, June 11, 1994. Civilians were given the opportunity to observe the 'inner life' of the former "Forbidden City" (Gehrke 2008: 74).

summary of the withdrawal, see Hoffmann \& Stoof 2013), the aim of a "worthy" final stage of the Russian troops in Germany was only partially successful. The farewell parade in Wünsdorf, broadcast live by the regional broadcaster Ostdeutscher Rundfunk Brandenburg (ORB), ${ }^{21}$ was an essential part of this project, and was meant to symbolically prove the new openness of the Russian troops. On June 11, 1994, thousands of people had the opportunity to observe the "inner life" of the former "Forbidden City". For an entrance fee of ten marks, most of the citizens of Wünsdorf could visit the inside area for the first time. In his farewell address, the Prime Minister at the time, Manfred Stolpe, thanked the Russian troops for their prudence in 1989 and 1990. "It was a folk festival, and everybody celebrated. We ate cake

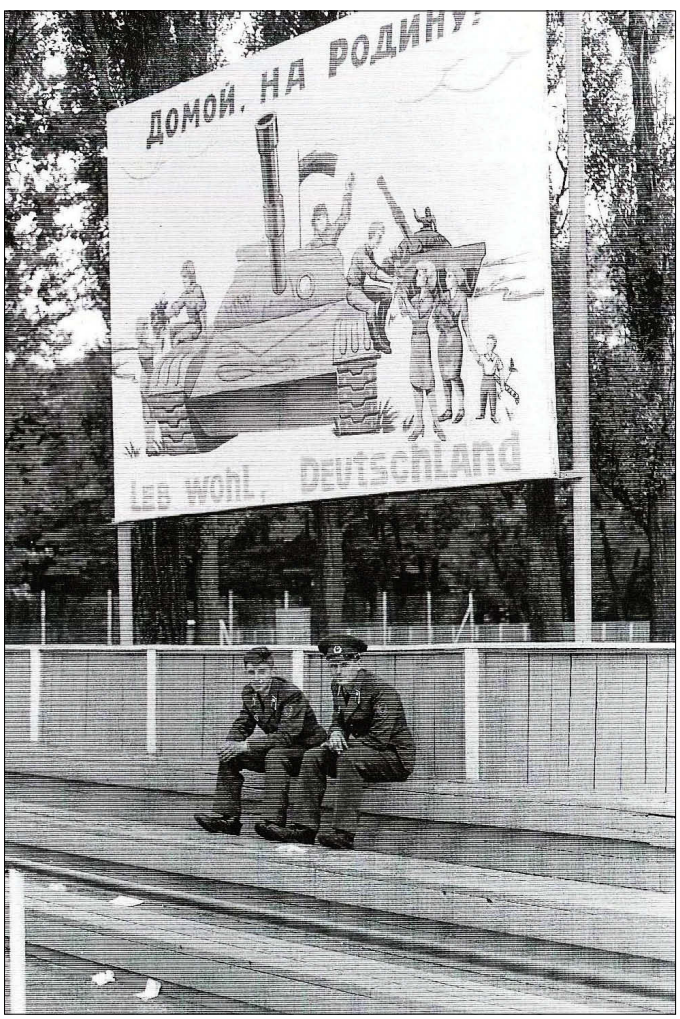
and solyanka, drank vodka, and I had tears in my eyes", Winfried Bläse, one of the interviewees, remembered. This observation sheds light on the perception of "foreign" food culture in the town with respect to the Russian "tradition" and its consequences of inter-cultural learning dynamics (for West Germany, see Möhring 2012). Born in 1950, Bläse had grown up with the Russians, and he and his family profited greatly from them. The period between 1990 and 1994 was, he added, "the best time of [his] life", ${ }^{22}$ not

Figure 5. The bilingual poster reads, "Homeward, to the motherland. Farewell, Germany!” Wünsdorf, June 11, 1994 (Gehrke 2008: 75). 
despite but rather because of the presence of the Soviet/Russian forces. The celebrations in summer 1994 were regarded as the symbolic culmination of a felicitous relationship.

While these festivities were remembered positively by some, they also evoked serious political inconsistencies, and this still plays a key role in many memories: on that day, politicians from the Brandenburg state government came, but no representatives from the federal government or the federal armed forces were present (Kampe 2009: 49). In most of the interviews, people mentioned their disappointment, describing how they interpreted this as a sign of arrogance, and thus a downgrading of the Russian troops by the Bonn government, which seemed to reflect an ongoing lack of respect for the Eastern Germans' lives, as well as for the Russian Army. Moreover, the Russian withdrawal was accompanied by different, either intended or unintended, forms of "tactlessness", misconceptions, and friction. One prominent example is the appointment of Hartmut Foertsch as the director of the liaison organization between the German and Russian Armies. Foertsch's father Friedrich had served as a general during the 900-day siege of Leningrad in 1941.

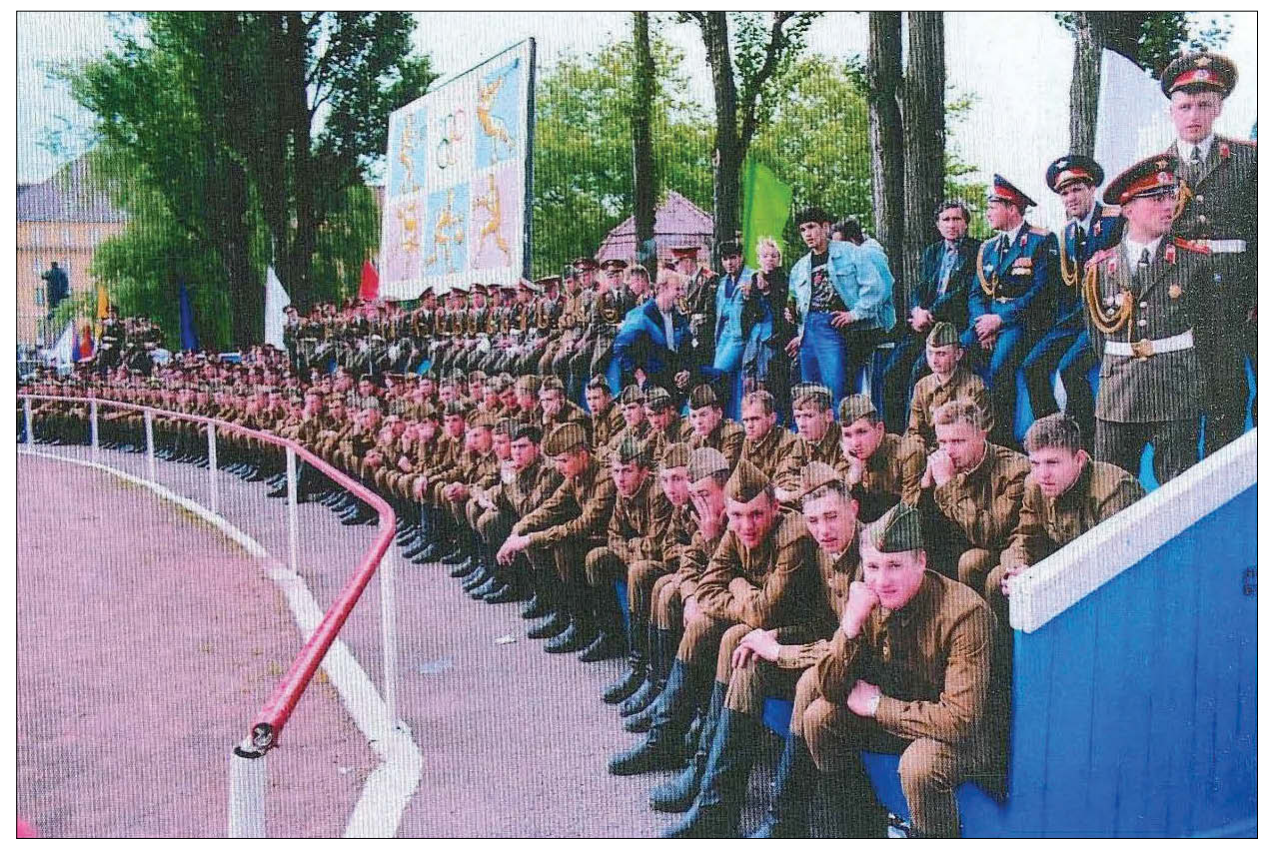

Figure 6. Spectators at martial arts performances in Wünsdorf. June 11, 1994 (Gehrke 2008: 61). 
In meetings with representatives of the German Federal Armed Forces (Bundeswehr), which were doubtless full of clear and mutual reservations, quite a few of the Russian commanders were dismayed at the fact that their property and goods had become (almost) valueless. Walter Meining, who took part in the negotiations with the Soviet Army, described the meetings as full of arrogance on the part of the Germans, "with only a few exceptions": Meining, for example, mentioned General Werner von Scheven, the Chief Officer of the Federal Armed Forces in the newly-formed German states, as a very fair-minded person who dealt with the Russians "eye to eye". ${ }^{23}$ Siegfried Marquart (born in 1947), a former high-ranking officer of the National People's Army (Nationale Volksarmee), remembered a "fundamental arrogant stupidity", intended to show the "other" (Russian) side that "we were back again". ${ }^{24}$ In the terms of the American sociologist Harold Garfinkel (1956), we may interpret these forms of (direct and indirect) encounters as "rituals of degradation" (for the administrative sphere, see Gravier 2003). These specific transitional rituals were typically associated with a discrediting of the past and thus indicated a revaluation of the past.

As the sociologist Nina Leonhard recently stated, these rituals were a fundamental condition for the negotiation of new identities among former members of the National People's Army after their integration into the Federal Armed Forces in October 1990. In this process, the label "army of unity" was invented (Leonhard 2016: 133-144). At that time, only a small number of soldiers were taken on permanently, which caused additional problems in accepting the new (military and societal) order. The views expressed above came from someone who spoke Russian fluently, spent several years in the Soviet Union, studied at the military academy in Moscow, and thus had countless encounters with Soviet/ Russian (civilian and military) citizens. These individual experiences shaped his perceptual patterns and may explain his feeling of being downgraded. Vice versa, this perceived devaluation most likely strengthened his already close attachment and solidarity with the former "brothers' army" further.

The circumstances of the parting ceremony evoked other notable moments of irritation, which had repercussions for the Wünsdorf locals and their remembrances, too. First, there was a great deal of astonishment over the idea of organizing the farewell ceremony for the Russian troops not as a common event with the British, American, and French military forces, but instead as a singular event held not even in Berlin, but in the National Theater in Weimar. "This is not our place", Matvei Burlakov said angrily, apparently referring to the liberation of the Buchenwald concentration camp in April 1945 by the American army and the following running of the camp by the People's Commissariat for Internal Affairs (Narodnyi Komissariat Vnutrennikh Del, NKVD). Until its 
dissolution in 1950, more than 7,000 people died of starvation, malnutrition, and disease in Special Camp No. 2.

It was not until the Social Democratic Party's (Sozialdemokratische Partei Deutschlands, SPD) leading politicians, including Wolfgang Thierse, Friedrich Schorlemmer, and Manfred Stolpe, sent a letter to Helmut Kohl asking him to change the location so as not to humiliate the Russians, that the chancellor settled on Berlin. Nonetheless, Bundeskanzler Kohl was still against a "joint and equal leaving of all allied forces in Germany" (Kaiser \& Herrmann 2010 [1993]: 185-186). Although according to a survey, 75\% of Germans supported a common celebratory ceremony, the German government opposed this idea, as they too deeply felt the ideological divide (ibid.). "Our soldiers do not leave as occupiers, but as partners and friends," Yeltsin stressed in his speech on August 31, 1994, during the official farewell ceremony in Berlin. But even the highly symbolic joint laying of a wreath at the Soviet memorial in BerlinTreptow and the emotional singing of the specially composed song titled "Lebe wohl, Deutschland, wir reichen dir die Hand" ('Goodbye Germany, We Reach Out Our Hands') could not hide the fact that the day was experienced and remembered as a "second class" leaving (Kaiser \& Herrmann 2010: 185-186). ${ }^{25}$

This symbolic and real distinction is also reflected in the interviews. The majority of the interviewees remembered the ceremonial dimension as being important and dignified because it symbolized gratitude, especially in the context of the Peaceful Revolution in 1989, when the Russian Army remained calm. In general, the interviewees would also have preferred a common ceremony with all four allied forces to prevent the Russian Army from appearing in an outsider role. However, four interviewees explicitly emphasized the importance of holding separate ceremonies. A separate event expressed the "hierarchy" among the occupying forces, with the Red Army being the least respected. Herbert Wüllenweber (born in 1951), who strongly supported separate ceremonies, explained his opinion via a biographical and generational experience: his father had been a front-line soldier on the Eastern Front, fighting against the Soviets. "I am in no way a friend of the Russians," he added, and he also mentioned the overly "arrogant and dolled-up Russian women" (Russenweiber) and not least the current political developments ("I am anything but a Putin whisperer" ${ }^{26}$ ). He clearly demonstrated that the interpretation of the past is always affected by knowledge of the present (Sabrow 2014: 36-37; for the context of the military transition, see Ehlert 2013; Thoß 2007). The feeling of cultural superiority may also have played a central role in retrospective descriptions and the reproduction of pejorative stereotypes like the ones discussed above (von Wrochem 2003: 62; for an overview, see Müller 2005). 
This mixture eventually also shaped the present-day perception and evaluation of Wünsdorf (and its desired future). In general, it is striking how the symbolic space of the former military base was influenced and dominated by a clear dichotomy regarding the images of the Soviets/Russians, which oscillated between idealizing descriptions and demonizing horror stories. While some of the interviewees tended to idealize the time with the Soviets and speak of it as the "most wonderful period of their lives" referring directly to the post-Russian time, which was in their eyes characterized by "disorder, decline, and dirt", and which transformed Wünsdorf into a dead ghost town, others did not even try to conceal their Russophobia. In the interviews, which were by no means free of polemics, a self-referential split was most clearly expressed via external and self-attribution and the categorization of "Russian friend", "whisperer", or "enemy", ${ }^{27}$ which very likely was not only the case in Wünsdorf but also in other former garrison towns, even outside Germany.

A noteworthy differentiation can be concluded regarding 1) the size and importance of Wünsdorf in the military network in the GDR and the whole Eastern bloc and, even more important, 2) the specific context of the reunited German society, which lies transversely to these processes of appropriation and negotiation and, subsequently, the (new/old, visible/invisible, open/subtle) borders which affect memories, narratives, and emotions. In this society different "arenas of transition" happened to occur: conflicting fields that represent problematic, conflictual, and often contradictory processes of merging, identification, and self-understanding (for a first draft of these "arenas", see Großbölting \& Lorke 2017).

As one example of an "arena", the case of Wünsdorf in its (Soviet/Russian) past and present clarifies the overlapping of current and long-lasting conflict situations in different dimensions: the military, political, social, cultural, memorial, collective, and individual. The Wünsdorf case represents not only how the different modes within the GDR past were negotiated repeatedly, but also how encounters with Russians (and references to them) before and after the period of 1989-1994 were highly determined by biographically acquired, available, and activated reservoirs of cultural and national clichés and stereotypes. Yet, there was also a recursiveness in the handling of the individual's past (Gallinat \& Kittel 2009; von Plato 2009) and in the negotiation of GDR and/or East German identity (Pollack \& Pickel 1998), which for many Wünsdorf locals even today is closely interwoven with the Soviet/Russian presence until 1994. 


\section{THE (LASTING) PROCESS OF CONVERSION: WÜNSDORF BETWEEN “HOBBYHORSE” AND "HUMBUG”}

When the last Russian soldier left Wünsdorf in September 1994, ownership of the property was assigned by the state of Brandenburg. The restructuring, renovation, and conversion of former military sites were great challenges financially, logistically, and symbolically. For Brandenburg, above all, the immense size of former military areas was a huge burden: about 120,000 hectares were transferred to the state by the federal government after the withdrawal in June 1994. In comparison to the other four New Länder, Brandenburg was the area most affected by military utilization of land and conversion. Thus, the importance of this task was codified in the Constitution of the Land of Brandenburg (Article 40; "Grund und Boden"). ${ }^{28}$ Quickly, the conversion of this intersection of German, European, and Soviet military history came to be a prestige project, the "hobbyhorse"29 of Prime Minister Manfred Stolpe (SPD), which took place under the heading Von der Konfrontation zur Kooperation ('From Confrontation to Cooperation'). But what can be done with an area six kilometers long and 800 meters wide, with a mix of contaminated soils and sites, approximately three million liters of kerosene, 300,000 tons of waste, ammunition, and a nature reserve, and how can the different layers of the past be integrated within a more or less "consistent" memorial narrative (Kaiser \& Herrmann 2010 [1993]: 204-205; Gießmann 1992: 199-206)?

One of the first major measures, aside from the return of property and houses, and one of the most notable elements of commemoration among the interviewees, was the reopening of federal highway B 96, which had been closed to through traffic since the 1950s. There are reasons why almost all of the interviewees mentioned the reopening. By 1991, several local initiatives had tried to reopen the highway, leading to an ongoing battle between the locals and the Russian troops. More than 1,000 applications arrived in the community's office. Eventually, the Russian commanders refused these requests on the grounds of possible noise pollution and the running out of goods in the Russian shops (Für die Wünsdorfer 1991). According to a journalist's observation, at that time the "German-Russian climate was extremely tense" (Liebold 1991). All the greater was the joy when the highway was eventually opened to public traffic in 1994. Many interviewees regarded this as a symbolic new beginning, ${ }^{30}$ and one of them even saw it as the "only positive effect of the withdrawal". ${ }^{31}$

The development company Landesentwicklungsgesellschaft (LEG) ${ }^{32}$ had ambitious plans, and in 1993 cited locational factors, such as its close proximity to Berlin, the labor potential, favorable traffic links, and landscape (Wieschollek 2005: 51-62). ${ }^{33}$ Eventually, nine development scenarios were proposed, 

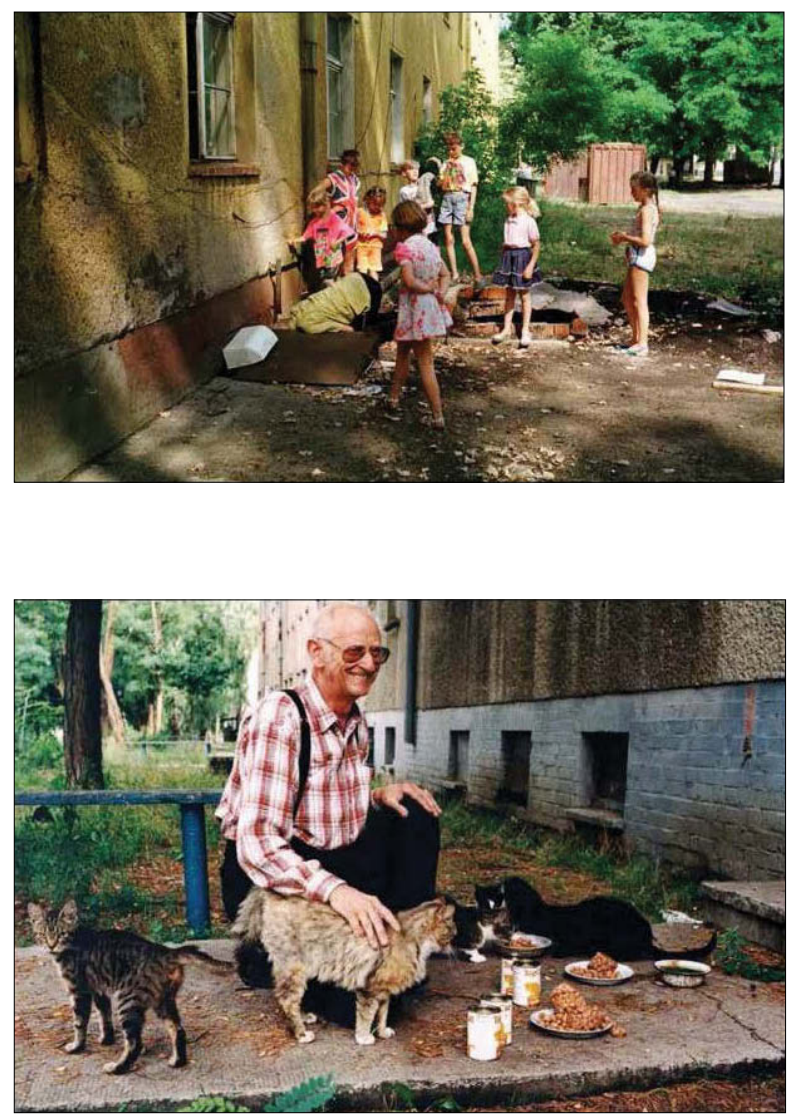

Figure 7-8. Glimpses of Wünsdorf after the withdrawal of Soviet forces in 1994. Garnisonsmuseum Wünsdorf.

ranging from a zero solution (i.e. renaturation), and an eco-city ("Architecture, Ecology, and Art”) to Germany's largest city for refugees (which, according to a documentary, led to many objections from the locals (see Richter 1993)), ${ }^{34}$ a leisure, service, technology, and innovation center like Silicon Valley, and a bureaucratic and satellite town with up to 20,000 inhabitants ("Good Night in Fresh Air”) (Kaiser \& Herrmann 2010 [1993]: 201-202; Brüske 1993; Hénard 1993). In April 1995, there was a cabinet decision to maintain the character of the area and, using the name Waldstadt ('Woody City'), which today is a part of the community of Wünsdorf, create a place for living, trading, administration, education, and working within an attractive environment. Furthermore, eighty million marks in aid money was made immediately available (Wieschollek 2005: 
70). In the end, none of the plans were realized. Considering the unemployment rate of up to $20 \%$ in Wünsdorf in the mid-1990s, the price of commercial spaces was presumably too high. On the other hand, there was no complete breakdown either, not least due to an immense amount of aid money from private initiatives and the European Union. Nowadays, there are approximately 6,500 inhabitants in Wünsdorf, half of whom live in Waldstadt.

By $2009,80 \%$ of the former military sites had been sold (Kaiser \& Herrmann 2010 [1993]: 204). However, as almost everywhere in East Germany, especially in rural areas, there is still a comparatively high number of empty properties in Wünsdorf, although that number has decreased slightly during the last ten years (for an overview, see Kratz 2003). Additionally, most likely as a strategic decision, the Brandenburg state agency for the road sector and the state office for the preservation of order are based in Wünsdorf and have several hundred employees.

The causes of this situation are complex and multilayered, as well as controversial: unused potential, conflicts over use, the lack of sufficient development, and the premature development of common visions, and missing or overestimated infrastructure are some of the general aspects which were mentioned regularly (Lohnes \& Kucera 1997; Wieschollek 2005: 131-160). Due to high expectations, the term "conversion" often has a negative connotation. In contrast, the interviewees were less squeamish, and they often used such phrases as utopian, unrealistic ideas, fantasies, "humbug", sinister and clandestine machinations and intrigues by third-class incompetent West German professionals, and unfeasible and useless ideas full of lobbying, trickery, and wheeling and dealing in the context of restructuring the former military property. ${ }^{35}$ For some of the interviewees, with the withdrawal of the Russians a part of the imagined GDR past left, too. Such statements may be interpreted as a delimitation of the "new time" and/or of the West Germans and, thus, a reaction to the perceived devaluation of the individual and collective life's work (Müller 2011: 368).

Today, there is a special focus on the touristic potential and European-wide important military history of Wünsdorf related to the Kaiser, Hitler, and the Russians, along with ties to the arts, culture, and nature. In September 1998, the first and only German "book town" was founded here, following a British model, in order to promote humanistic ideas, appreciation of books and the closed bunkers as symbols of peace, and to encourage a sensible approach to the past and present. ${ }^{36}$ The private limited company Bücherstadt-Tourismus GmbH organizes different thematic guided tours through the "Forbidden City", accompanied by campfires, the serving of stew from a field kitchen, military-historical seminars, encounters with military vehicles, an "underground Sunday" in the "zeppelin" signal bunker, and readings. Even though the book town project is regarded as 


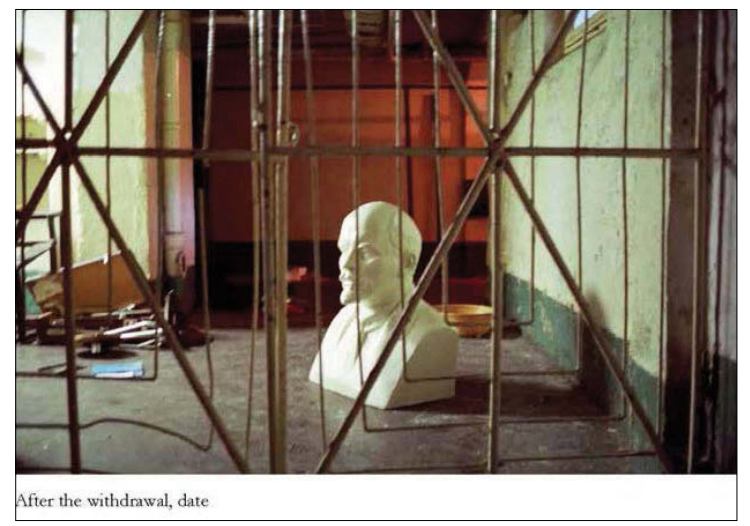

Figure 9-10. Glimpses of Wünsdorf after the withdrawal of Soviet forces in 1994. Garnisonsmuseum Wünsdorf.

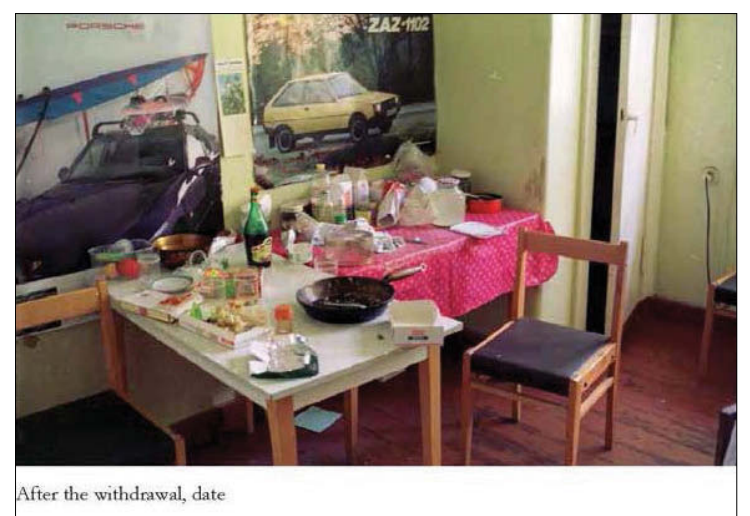

a success (e.g. Arlt 2010: 672), it is in a constant struggle for its existence: of the twenty original antiquarian booksellers, only three have survived, and there are 400,000 books waiting to be sold (Mallwitz 2015). There is also a garrison museum, Roter Stern ('Red Star'), which is supported by a local booster club and gives an interesting but quite uncritical overview of the Soviet/Russian stay in Germany, with both permanent and changing exhibitions showing the didactic and educational efforts to preserve the memory of Wünsdorf's military past (Fischer 2000; 2010).

It is evident that these developments shaped memorial representations as well as the practical aspects of managing the former military past. In Wünsdorf, there are still initiatives to deal with the military heritage in general and the withdrawal of the army in particular. In order to preserve the memory of the Soviet presence, a ring road in Wünsdorf was named after Pjotr Koschewoj, a former Soviet marshal who was based there for several years. The renaming 
Figure 11. A glimpse of Wünsdorf after the withdrawal of Soviet forces in 1994. Garnisonsmuseum Wünsdorf.

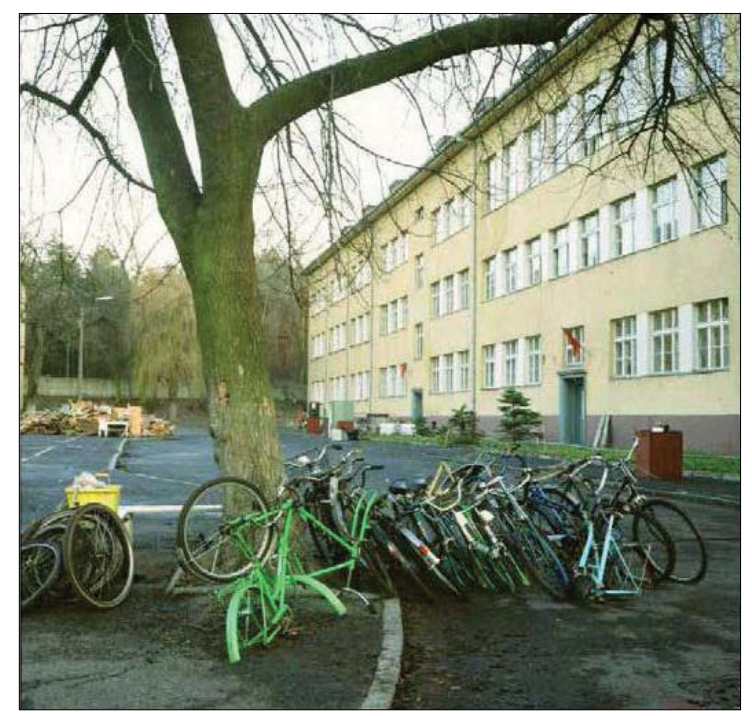

was a response to the failed initiative of the Freunde der Bücherstadt Wüns$\operatorname{dorf}$ ('Friends of the Wünsdorf Book Town') to rename another street after the controversial commander Burlakov (Degener 2014a). As a common initiative of the Bücherstadt Wünsdorf and the Russian embassy, on the 20th anniversary of the withdrawal, in 2014, Anton Terentjew, who was a colonel general in Wünsdorf in 1993 and 1994 and thus played a significant role in the process of the withdrawal, returned and thanked the locals for their "maintenance of tradition" (Die Rückkehr 2014; Degener 2014b). On that day, gratitude for Europe's liberation from fascism was expressed in Wünsdorf, including greetings from local and national politicians, although at that time the conflict between Russia and the Ukraine was underway.

Among Russians, there is significant interest in and willingness to visit Wünsdorf, and especially among the younger generation there is a vibrant online culture of commemoration, for example, in the social medium VK. ${ }^{37}$ The lively exchange of class photographs may not be merely a surrogate for remembering their "homeland", and many plan to visit the place of their childhood as potential "homesick tourists" (provided they have the financial ability to do so). ${ }^{38}$ This specific double perspective was also registered by the locals and emphasized in some of the interviews: for many Russians, Wünsdorf became their "homeland", as Dietrich Meyer (born in 1943) highlighted, and their withdrawal was "tantamount to a catastrophe". ${ }^{39}$ 


\section{CONCLUSION: REINTERPRETING THE MILITARY PAST IN WÜNSDORF}

As discussed above, the permanent presence of Soviets/Russians has left deep traces in Wünsdorf regarding the creation of (new) cultural and spatial, as well as social and individual, identities. The variety of the collective and individual handling of the legacies of the Cold War in Wünsdorf nowadays illustrates different forms of appropriating, updating, reinforcing, neglecting, and excluding certain elements of the Soviet/Russian past. Opinions about the Russians before 1990 are cross-generational and still present today, and they now stretch the full range from anti-Russian sentiments and the commemoration of a highly negative concept of "foreign domination" to feelings of belittlement and continuing melancholy.

This finding corresponds with a survey of East Germans by the Institut für Demoskopie Allensbach ('Allensbach Institute for Public Opinion Research') in 1994, when $32 \%$ of the respondents assessed the Russian troops as "mostly friends and allies", while $42 \%$ regarded them as "mostly an occupying power" (Müller 2011: 144). Even if one concedes that the sample of the present study represents a multiple skewed perspective - those who responded to the press call had "something to say" and a special "need for communication" - the conclusions strengthen the argument presented by historian Evemarie BadstübnerPeters, who claimed that the Soviet (Russian) influence was a constant and highly relevant factor in everyday life, to a far greater extent than assumed previously. Its impact is noticeable even today. The "difficult handling of the difficult foreignness" (Badstübner-Peters 1997a; 1997b) most likely not only influenced behavioral and orientation uncertainties after 1990, in regard to dealing with foreign cultures and lifestyles, but also led to different ways of coming to terms with the past, which reflects a highly ambivalent memorial landscape and current (geo)political and diplomatic developments. These findings can be classified as selected practices of "othering" in terms of a certain space, where "foreignness" can be interpreted as a result of everyday interaction, construction, identification, and irritation. This also reflects on both existing and obsolete ideas of social, economic, cultural and ethnic order within a certain space, and the embedded role of the "foreign" that over many years significantly influenced the local symbolic order (Geenen 2002: 245-247; Reuter 2002).

In terms of the future, many residents place plenty of hope in the completion of a major airport for Berlin. The Waldstadt page advertises a "space for visions", an "exceptional environment", the "best infrastructure and transport link", a place with a historical location, vivid culture, and "enchanting lake 
scenery", which is, however, still in a "deep sleep". The "very low commercial tax rate" and, above all, the proximity to the future Berlin airport would offer "unlimited opportunities". ${ }^{40}$ Many interviewees mentioned this scenario too, and not only the relocation of "noise refugees" (i.e. people escaping the noise of city life), but also the existence of a major Russian investor were mentioned. ${ }^{41}$

Taking a quick glance at its current status, in the past year approximately 1,500 refugees were admitted for the first time to live at the former military base in Wünsdorf (Fischer 2015). In May 2015, two local right-wing youths attacked the complex with fireworks. The local initiative Wünsdorf wehrt sich ('Defending Wünsdorf') organized several demonstrations last autumn, warning against crime, disease, and sexual assault. At the end of the event, the crowd loudly demanded the withdrawal of Chancellor Angela Merkel and sang the national anthem (Brockhausen \& Rohowski 2015). Their Facebook page has more than 3,100 likes (as of September 2017), much more than the 643 likes for the local refugee aid campaign from the same month, and notable statements by their followers include: "I really preferred the Russians much more", or "If only the Russians were still here". Statements like these again powerfully demonstrate how for many locals the unloved past can be updated (and upgraded) when new symbolic hierarchies are required and new borders have to be established. For the time being, the question must remain open, as an interviewee suggested, as to whether some of the residents have difficulties handling any type of foreignness: "Fear of Russians, fear of wolves, fear of refugees - this is a constant feature of Wünsdorf's history". ${ }^{42}$ The last statement indicates a divergent type of "foreignness", which privileges the Soviet/Russian past in Wünsdorf. It again proves that how to deal with former Soviet bases in Germany is strongly influenced by the different layers of the aftermath in the context of the German reunification and the lasting effects of the "power of unofficial memory" (Burke 1991: 300).

\section{ACKNOWLEDGEMENTS}

I would like to thank Sabine Kittel and Lilith Buddensiek for the first, unofficial proofreading. I would also like to thank the anonymous reviewers along with the editors for providing indispensable suggestions on how to more effectively structure this essay. 


\section{NOTES}

1 This was the name beginning in 1988. From 1954 the name was the Group of Soviet Forces in Germany. The Soviets stayed based on the "Treaty on Relations between the USSR and the GDR" (1955).

${ }^{2}$ For a summary of the locations, see the database edited by the Militärgeschichtliches Forschungsamt ('Military History Research Office'), available at http://www.mgfa.de/ html/standorte_einleitung.php, last accessed on August 23, 2017.

3 For example: Altengrabow, Karl-Marx-Stadt, Dresden, Grimma, Halle, Hillersleben, Jena, Magdeburg, Merseburg, Rostock, Schwerin, Stendal, Weimar, or Wittenberg.

4 Bernau, Cottbus, Dallgow, Eberswalde, Fürstenberg, Jüterbog, Perleberg, Potsdam, Neuruppin, Neustrelitz, Rathenow, or Vogelsang, to name only a few.

5 See the contribution by Evgeny V. Volkov in this volume.

6 In detail: "Märkische Allgemeine”, "Wochenspiegel”, "Blickpunkt", "Teltow-Kanal", "Stadtblatt Zossen", and the homepage of the community of Zossen (available at www. zossen.de, last accessed on August 23, 2017).

7 The questions were: 1) What part did the Soviet troops and the place of Wünsdorf play for you before the year 1989? 2) How would you describe or characterize the "interim phase" between 1989 (the fall of the Berlin Wall) and 1994 (the withdrawal of the troops)? 3) How did you experience the process of withdrawal: the mood in Wünsdorf among the local residents as well as among the soldiers? What has happened to this place since then? These open questions allowed enough space for additional remarks by the interviewees and also for further inquiries on my part.

8 This is not the place to propose a broader discussion of the term "generation". Very briefly, subdividing these people into generations (Ahbe \& Gries 2006), eight interview partners (40\%) belonged to the Aufbau-Generation ("Construction Generation"), born between 1920 and the mid-1930s, seven (35\%) to the funktionierende Generation ("Functioning Generation"), born from the mid-1930s until the end of the 1940s, and five (25\%) to the integrierte Generation ("Integrated Generation"), born in the 1950s. What is important here is the fact that the majority of my interview partners were from the Aufbau- and funktionierende Generation, which shows their interest as well as personal/emotional involvement.

9 The only interviewed woman mentioned that in the context of the end of World War II the locals were "frightened". Interview with Ilse Bollmann (born in 1929), February 26, 2016. To protect their privacy, all names of the interviewees have been fictionalized and created by the author.

${ }^{10}$ Interview with Ilse Bollmann, February 26, 2016.

11 "F" stands for Fernverkehrsstraße; in 1990, the name was changed to B 96 -Bundesstraße ('Federal Highway').

${ }^{12}$ Interview with Gerhard Dombritz, February 18, 2016. 
${ }^{13}$ Only a small selection: Sowjettruppen 1990; Schwelien 1991; Mafia 1991; Unsere Leute 1993; Habbe 1993; Militär 1994; Zwischenbilanz 1994.

${ }^{14}$ Interview with Günther Heisig, February 19, 2016; similar statements were mentioned in the interviews with Walther Meining (born in 1935), March 1, 2016, and Willy Tuchscherer (born in 1932), March 5, 2016.

${ }^{15}$ See, for instance, the following selection of media articles: Furman 1991; Lippold 1991; Schwelien 1991. Resentment was mentioned in detail in one interview, with Gerd Langer (born in 1931), March 3, 2016. These verbal attacks were addressed both to soldiers and the families of higher ranks.

${ }^{16}$ Interviews with Arnold Klein, February 25, 2016, and Bernhard Michel (born in 1939), March 19, 2016.

${ }^{17}$ Interview with Ilse Bollmann, February 26, 2016.

${ }^{18}$ Interviews with Winfried Bläse, March 3, 2016, and Bernhard Michel, March 19, 2016.

${ }^{19}$ For example, in the interviews with Werner Schmidt (born in 1933), February 28, 2016, and Harald Weber (born in 1951), March 3, 2016.

${ }^{20}$ Interview with Heinz Bremer, March 8, 2016; see also Kowalczuk \& Wolle 2010: 223.

${ }^{21}$ Die Russischen Truppen verabschieden sich. ORB, June 11, 1994; 02'20, Deutsches Rundfunarchiv Babelsberg, No. 9400834. See also a short extract available at https:// www.youtube.com/watch?v=ShYQFoh2290, last accessed on August 23, 2017.

${ }^{22}$ Interview with Winfried Bläse, March 3, 2016.

${ }^{23}$ Interview with Walther Meining, March 1, 2016.

${ }^{24}$ Interview with Siegfried Marquardt, March 7, 2016.

${ }^{25}$ See also Staatsfeiern 1994; Hénard 1994; Jelzin-Besuch 1994.

${ }^{26}$ Interview with Herbert Wüllenweber, March 15, 2016.

${ }^{27}$ Interview with Gerhard Dombritz, February 18, 2016.

${ }^{28}$ See https://bravors.brandenburg.de/de/gesetze-212792, last accessed on August 23, 2017.

${ }^{29}$ Hobbyhorse. Märkischen Allgemeine Zeitung. January 25, 2002.

${ }^{30}$ Interview with Walther Meining, March 1, 2016.

${ }^{31}$ Interview with Winfried Bläse, March 3, 2016.

${ }^{32}$ Landesentwicklungsgesellschaft (state development corporation). In June 1995 the LEG, which was operating in deficit, was succeeded by the Entwicklungsgesellschaft Waldstadt Wünsdorf/Zehrensdorf (EWZ). For further background information, see Wieschollek 2005. 
${ }^{33}$ Infrastructural and financial limitations (mainly, being far from Berlin's sphere of influence, a remarkable workforce potential that was concentrated only in a few economic sectors, and a lack of investor interest) were discussed, too.

${ }^{34}$ Following this article, observations could be made that Wünsdorf local residents occasionally stated that foreigners would be the least favorable new neighbors.

${ }^{35}$ Interviews with Günther Heisig (born in 1933), February 19, 2016; Winfried Bläse, March 3, 2016; Herbert Wüllenweber, March 15, 2016; and Bernhard Michel (born in 1939), March 19, 2016.

${ }^{36}$ Bücher und Bunkerstadt Wünsdorf. Bücherstadt-Tourismus GmbH. Available at www. buecherstadt.com, last accessed on August 23, 2017.

${ }^{37}$ For instance, see GSVG $\star \mathrm{ZGV} \star$ VIuNSDORF $\star$ WUNSDORF $\star$ GDR $\star$ DDR, available at https://new.vk.com/wunsdorf; Vse kto sluzhil v Viunsdorfe GSVG i ZGV (Everyone who served in Wünsdorf in the Group of Soviet Forces in Germany (GSFG) and in the Western Group of Forces (WGF)), available at https://new.vk.com/ club4598721; Shkola 89 GSVG/ZGV Viunsdorf (School No. 89 GSFG/WGF), available at https://new.vk.com/club156004; ZGV. Viunsdorf. Shkola №1 (WGF. Wünsdorf, School No. 1), available at https://new.vk.com/club58542; ZGV Viunsdorf NIKEL' p.p.35714 (WGF Wünsdorf Nikel p.p.35714), available at https://new.vk.com/club1056642; http:// wunsdorf.livejournal.com, all last accessed on August 23, 2017.

${ }^{38}$ Wunsdorf, DDR - Posledniaia osen' / / Letzten Herbst. Available at https://www. youtube.com/watch?v=LEOeTtfCigo, last accessed on August 23, 2017.

${ }^{39}$ Interview with Dietrich Meyer, March 10, 2016.

${ }^{40}$ Die Waldstadt Wünsdorf. Available at http://www.waldstadt-wuensdorf.de, last accessed on August 23, 2017.

${ }^{41}$ Interview with Bernd Holtzschke (born in 1939), March 8, 2016; see also van der Kraat 2014.

${ }^{42}$ Interview with Heinz Küstner (born in 1935), March 8, 2016.

\section{REFERENCES}

Abdullah, Muhammad S. 1984. Halbmond unter dem Preußenadler: Die Geschichte der islamischen Gemeinde in Preußen (1731-1934). Altenberg: Verlag für ChristlichIslamisches Schrifttum.

Abschied in Würde 1994 = Abschied in Würde: Die 'Westgruppe der Truppen' verließ Deutschland. Wehrtechnik, Vol. 26, No. 9, pp. 8-12.

Ahbe, Thomas \& Gries, Rainer 2006. Gesellschaftsgeschichte als Generationengeschichte: Theoretische und methodologische Überlegungen am Beispiel der DDR. In: Annegret Schüle \& Rainer Gries \& Thomas Ahbe (eds.) Die DDR aus generationengeschichtlicher Perspektive: Eine Inventur. Leipzig: Leipziger Universitätsverlag, pp. 475-571. 
Arlt, Kurt 1998. Sowjetische (russische) Truppen in Deutschland (1945-1994). In: Torsten Diedrich \& Hans Ehlert \& Rüdiger Wenzke (eds.) Im Dienste der Partei: Handbuch der bewaffneten Organe der DDR. Berlin: Links, pp. 593-632.

Arlt, Kurt 2010. Zossen. In: Kurt Arlt \& Michael Thomae \& Bruno Thoß (eds.) Militärgeschichtliches Handbuch Brandenburg-Berlin. Berlin: be.bra Wissenschaftsverlag, pp. 666-672.

Assmann, Aleida 2009. Geschichte findet Stadt. In: Moritz Csáky \& Christoph Leitgeb (eds.) Kommunikation - Gedächtnis - Raum: Kulturwissenschaften nach dem 'Spatial Turn'. Bielefeld: Transcript, pp. 13-27.

Assmann, Jan 1997 [1992]. Das kulturelle Gedächtnis: Schrift, Erinnerung und politische Identität in frühen Hochkulturen. München: Beck.

Augé, Marc 1992. Non-Lieux: Introduction à une anthropologie de la surmodernité. Paris: Le Seuil.

Badstübner-Peters, Evemarie 1997a. Über uns und über die 'Russen': Zur Alltagsgeschichte (ost)deutsch-sowjetischer Beziehungen. In: Ludwig Elm \& Dietmar Keller \& Reinhard Mocek (eds.) Ansichten zur Geschichte der DDR, Band 7. Eggersdorf: Verlag Matthias Kirchner, pp 251-275.

Badstübner-Peters, Evemarie 1997b. Ostdeutsche Sowjetunionerfahrungen: Ansichten über Eigenes und Fremdes in der Alltagsgeschichte der DDR. In: Konrad H. Jarausch \& Hannes Siegrist (eds.) Amerikanisierung und Sowjetisierung in Deutschland 1945-1970. Frankfurt am Main \& New York: Campus, pp. 291-311.

Bassistow, Juri W. 1994. Die DDR - ein Blick aus Wünsdorf. Persönliche Eindrücke eines russischen Offiziers. Jahrbuch für historische Kommunismusforschung, pp. 215-224.

Behrends, Jan C. 2003. Sowjetische 'Freunde' und fremde 'Russen'. Deutsch-sowjetische Freundschaft zwischen Ideologie und Alltag (1949-1990). In: Jan C. Behrends \& Thomas Lindenberger \& Patrice G. Poutrus (eds.) Fremde und Fremd-Sein in der DDR: Zu historischen Ursachen der Fremdenfeindlichkeit in Ostdeutschland. Berlin: Metropol, pp. 75-100.

Brockhausen, Stefanie \& Rohowski, Tina 2015. Wünsdorfer stemmen sich gegen 'fanatische Willkommenskultur': Aggressive Stimmung beim Infoabend $\mathrm{zu}$ neuem Flüchtlingsheim. https://www.rbb-online.de/politik/thema/fluechtlinge/ brandenburg/2015/11/buergerversammlung-erstaufnahme-fluechtlinge-zossenwuensdorf.html, last accessed on July 14, 2016; no longer available.

Brüske, Klaus 1993. Nach 100 Jahren endlich zivil: Wünsdorf spielt Nutzungsvarianten für das riesige GUS-Gelände durch. Berliner Zeitung, August 27.

Burke, Peter 1991. Geschichte als soziales Gedächtnis. In: Aleida Assmann \& Dietrich Harth (eds.) Mnemosyne: Formen und Funktionen der kulturellen Erinnerung. Frankfurt am Main: Fischer, pp. 289-304.

Burlakov, Matvei P. 1994. Wirverabschieden uns. Als Freunde:Der Abzug-Aufzeichnungen des Oberkommandierenden der Westtruppe der sowjetischen Streitkräfte. Bonn: InnoVatio-Verlag.

Danyel, Jürgen 2015. Alltag Einheit: Ein Fall fürs Museum! Aus Politik und Zeitgeschichte, Vol. 65, No. 33-34, pp. 26-35.

Degener, Peter 2014a. Sowjet-Marschall als Namenspatron: In Wünsdorf soll eine Umgehungsstraße 'Koschewoi-Ring' heißen. Märkische Allgemeine Zeitung, April 8. 
Degener, Peter 2014b. Festakt mit dem russischen Botschafter: Gedenken an Abzug der russischen Truppen in Wünsdorf. Märkische Allgemeine Zeitung, June 7.

Die Rückkehr 2014 = Die Rückkehr des Stabschefs: Generaloberst Terentjew besuchte das Museum 'Roter Stern'. Märkische Allgemeine, February 7. Available at http:// www.genios.de/presse-archiv/inhalt/MAER/20140207/1/maerkische-allgemeine. html, last accessed on August 24, 2017.

Ehlert, Hans 2013. Abgewickelt - Die Nationale Volksarmee der DDR im Vorfeld der deutschen Einheit. In: Christian Th. Müller \& Matthias Rogg (eds.) Das ist Militärgeschichte! Probleme - Projekte - Perspektiven. Paderborn: Ferdinand Schöningh, pp. 173-190.

Erll, Astrid 2005. Kollektives Gedächtnis und Erinnerungskulturen: Eine Einführung. Stuttgart: Metzler.

Fischer, Oliver 2015. Aufgeheizte Stimmung in Wünsdorf. Märkische Allgemeine Zeitung / Zossener Rundschau, November 27.

Fischer, Silvio 2000. Der frühere Militärstandort Wünsdorf - Ein Ort des Erinnerns? In: Burkhard Assmus \& Hans-Martin Hintz (eds.) Zum Umgang mit historischen Stätten aus der Zeit des Nationalsozialismus. Berlin: Bundesministerium für Bildung und Forschung \& Deutsches Historisches Museum, pp. 129-147.

Fischer, Silvio 2010. Der frühere Militärstandort Wünsdorf: Ein Ort des Erinnerns. Museumsblätter: Mitteilungen des Museumsverbandes Brandenburg, Heft 16, pp. 44-45. Available at http://www.museen-brandenburg.de/fileadmin/pdfs/ Museumsblaetter/Heft_16/k_16_Fischer.pdf, last accessed on August 23, 2017.

Foertsch, Hartmut 1994. Der Abzug russischer Truppen aus Deutschland: 'Keiner sagt: Jungs, kommt bald wieder'. Europäische Sicherheit, Vol. 43, No. 3, pp. 125-127.

Für die Wünsdorfer 1991 = Für die Wünsdorfer bleibt die B 96 weiterhin gesperrt: Gemeindevertreter gaben ihre Passierscheine zurück. Berliner Zeitung, May 18.

Furman, Alexander 1991. Zerrissen ist die russische Seele: Die Sowjetsoldaten leben schlecht zu Hause und einsam in Deutschland. Die Zeit, January 4. Available at http://www.zeit.de/1991/02/zerrissen-ist-die-russische-seele, last accessed on August 23, 2017.

Gallinat, Anselma \& Kittel, Sabine 2009. Zum Umgang mit der DDR-Vergangenheit heute: Ostdeutsche Erfahrungen, Erinnerungen und Identität. In: Thomas Großbölting (ed.) Friedensstaat, Leseland, Sportnation? DDR-Legenden auf dem Prüfstand. Berlin: Links, pp. 304-328.

Garfinkel, Harold 1956. Conditions of Successful Degradation Ceremonies. American Journal of Sociology, Vol. 61, No. 5, pp. 420-424. http://dx.doi.org/10.1086/221800.

Geenen, Elke M. 2002. Soziologie des Fremden: Ein gesellschaftstheoretischer Entwurf. Opladen: Leske \& Budrich.

Gehrke, Thilo 2008. Das Erbe der Sowjetarmee in Deutschland: eine Bild- und Textdokumentation. Berlin: Köster.

Gießmann, Hans-Joachim 1992. Das unliebsame Erbe: Die Auflösung der Militärstruktur der DDR. Baden-Baden: Nomos-Verlag.

Gravier, Magali 2003. Entrer dans l'administration de l'Allemagne unifiée: une approche anthropologique d'un rituel d'intégration (1990-1999). Revue française de science politique, Vol. 53, No. 3, pp. 323-350. Available at https://www.cairn.info/revuefrancaise-de-science-politique-2003-3-page-323.htm, last accessed on August 23, 2017. 
Großbölting, Thomas 2010. Eine zwiespältige Bilanz: Zwanzig Jahre Aufarbeitung der DDR-Vergangenheit im wiedervereinigten Deutschland. In: Thomas Großbölting \& Raj Kollmorgen \& Sascha Möbius \& Rüdiger Schmidt (eds.) Das Ende des Kommunismus: Die Überwindung der Diktaturen in Europa und ihre Folgen. Essen: Klartext-Verlag, pp. 61-75.

Großbölting, Thomas \& Lorke, Christoph (eds.) 2017. Deutschland seit 1990: Wege in die Vereinigungsgesellschaft. Stuttgart: Franz Steiner-Verlag.

Grothusen, Söhnke \& Morais, Vânia \& Stöckmann, Hagen (eds.) 2014. Generation und Raum: Zur symbolischen Ortsbezogenheit generationeller Dynamiken. Göttingen: Wallstein.

Habbe, Christian 1993. Jottwehdeh und Zaun drum. Spiegel Special, February 1. Available at http://www.spiegel.de/spiegel/spiegelspecial/d-52535779.html, last accessed on August 23, 2017.

Hénard, Jaqueline 1993. Allerlei Ideen für die Zukunft Wünsdorfs: Hauptquartier der Russen bei Berlin. Frankfurter Allgemeine Zeitung, July 16.

Hénard, Jacqueline 1994. Der Abschied der Alliierten aus Berlin hat schon begonnen. Frankfurter Allgemeine Zeitung, March 19.

Hoffmann, Hans-Albert \& Stoof, Siegfried 2013. Sowjetische Truppen in Deutschland und ihr Haupt-quartier in Wünsdorf 1945-1994: Geschichte, Fakten, Hintergründe. Berlin: Köster.

Höpp, Gerhard 1997. Muslime in der Mark: Als Kriegsgefangene und Internierte in Wünsdorf und Zossen, 1914-1924. Berlin: Das Arabische Buch.

Jelzin-Besuch 1994 = Jelzin-Besuch: Gute Nacht! Hände hoch! Der Spiegel, May 9. Available at http://www.spiegel.de/spiegel/print/d-13855499.html, last accessed on August 24, 2017.

Kaiser, Gerhard 1998. Sperrgebiet: Die geheimen Kommandozentralen in Wünsdorf seit 1871. Berlin: Links.

Kaiser, Gerhard \& Herrmann, Bernd 2010 [1993]. Vom Sperrgebiet zur Waldstadt: Die Geschichte der geheimen Kommandozentralen in Wünsdorf und Umgebung. Berlin: Links.

Kampe, Hans G. 2009. Das Oberkommando der GSSD in Zossen-Wünsdorf: Zentrum der sowjetischen/russischen Militärpolitik in der DDR. Berlin: Hoppegarten, Projekt + Verlag Dr. Erwin Meißler.

Keller, Reiner 2016. Die symbolische Konstruktion von Räumen: Sozialkonstruktivistischdiskursanalytische Perspektiven. In: Gabriela B. Christmann (ed.) Zur kommunikativen Konstruktion von Räumen: Theoretische Konzepte und empirische Analysen. Wiesbaden: Springer, pp. 55-78. Available at http://www.springer.com/ de/book/9783658008666, last accessed on August 24, 2017.

Kollmorgen, Raj 2010. Diskurse der deutschen Einheit. Aus Politik und Zeitgeschichte, Vol. 60, Nos. 30-31, pp. 6-13. Available at http://www.bpb.de/shop/zeitschriften/ apuz/32599/deutsche-einheit, last accessed on August 24, 2017.

König, Ewald 2010. Burlakows Westgruppe und der Osten. Available at http://www. euractiv.de/section/wahlen-und-macht/news/burlakows-westgruppe-und-derosten/, last accessed on August 24, 2017.

Kowalczuk, Ilko-Sascha \& Wolle, Stefan 2010. Roter Stern über Deutschland: Sowjetische Truppen in der DDR. Berlin: Links. 
Kraat, Marion van der 2014. Vor Sperrgebiet zum Alltag: Wünsdorfs schwieriges Erbe. 20 Jahre nach dem Abzug der sowjetischen Streitkräfte ringt die "verbotene Stadt" um ihre Zukunft. Märkische Allgemeine, August 29. Available at http:// www.genios.de/presse-archiv/artikel/MAER/20140829/vom-sperrgebiet-zumalltag-wuensdor/201408293834714.html, last accessed on September 28, 2017.

Kratz, Walther 2003. Konversion in Ostdeutschland: Die militärischen Liegenschaften der abgezogenen Sowjetischen Streitkräfte, ihre Erforschung, Sanierung und Umwidmung. Berlin: Trafo.

Leonhard, Nina 2016. Integration und Gedächtnis: NVA-Offiziere im vereinigten Deutschland. Konstanz: UVK.

Leydesdorff, Selma 1996. Gender and Memory. Oxford: Oxford University Press.

Liebold, Edda 1991. Jenseits der grauen Mauer: Die Rote Armee bläst zum Abmarsch eine alte Garnison ordnet sich neu. Die Zeit, June 21. Available at http://www. zeit.de/1991/26/jenseits-der-grauen-mauer, last accessed on August 24, 2017.

Lippold, Frank E. 1991. Im Schnelldurchlauf durch Küche und Quartiere: Bundesverteidigungsminister Stoltenberg bei Westgruppe der sowjetischen Truppen. Berliner Zeitung, April 27.

Locke, Stefan 2014. Niemand geht so ganz. Die Zeit, March 27. Available at http://www. zeit.de/2014/14/russen-soldaten-abzug-ddr, last accessed on August 24, 2017.

Lohnes, Patricia \& Kucera, Katerina 1997. Konversion ehemalig militärisch genutzter Liegenschaften in den neuen Bundesländern - am Beispiel des Militärstandortes Wünsdorf. Diploma thesis, University of Kaiserslautern, Germany.

Loth, Wilfried 1998. Stalin's Unwanted Child: The Soviet Union, the German Question, and the Founding of the GDR. London: Palgrave Macmillan. DOI: 10.1007/9781-349-26400-1.

Mafia 1991 = Mafia: Schweigen oder sterben. Der Spiegel, November 4. Available at http:// www.spiegel.de/spiegel/print/d-13490911.html, last accessed on August 24, 2017.

Mallwitz, Gudrun 2015. Einstige Russen-Stadt soll 1200 Flüchtlinge aufnehmen. Berliner Morgenpost, June 14. Available at https://www.morgenpost.de/brandenburg/ article142469462/Einstige-Russen-Stadt-soll-1200-Fluechtlinge-aufnehmen. html, last accessed on August 24, 2017.

Militär 1994 = Militär: Leichen im See. Der Spiegel, January 24. Available at http:// www.spiegel.de/spiegel/print/d-9275411.html, last accessed on August 24, 2017.

Möhring, Maren 2012. Fremdes Essen: Die Geschichte der ausländischen Gastronomie in der Bundesrepublik Deutschland. München: Oldenbourg.

Müller, Christian Th. 2005. 'O' Sowjetmensch! Beziehungen von sowjetischen Streitkräften und DDR-Gesellschaft zwischen Ritual und Alltag. In: Christian Th. Müller \& Patrice G. Poutrus (eds.) Ankunft - Alltag - Ausreise: Migration und interkulturelle Begegnung in der DDR-Gesellschaft. Köln \& Weimar \& Wien: Böhlau, pp. 17-134.

Müller, Christian Th. 2011. US-Truppen und Sowjetarmee in Deutschland: Erfahrungen, Beziehungen, Konflikte im Vergleich. Paderborn: Ferdinand Schöningh.

Naumann, Klaus 1996 [1993]. NVA: Anspruch und Wirklichkeit nach ausgewählten Dokumenten. Hamburg \& Berlin \& Bonn: Mittler.

Nawrocki, Joachim 1994. Abschied in Würde, Ankunft in Armut. Die Zeit, February 18. Available at http://www.zeit.de/1994/08/abschied-in-wuerde-ankunft-in-armut, last accessed on August 24, 2017. 
Obertreis, Julia \& Stephan, Anke (eds.) 2009. Erinnerungen nach der Wende: Oral History und (post)sozialistische Gesellschaften. Essen: Klartext.

Plato, Alexander von 2009. Oral History nach politischen Systembrüchen. Erfahrungen in Deutschland Ost und West: Einige Annäherungen. In: Julia Obertreis \& Anke Stephan (eds.) Erinnerungen nach der Wende: Oral History und (post)sozialistische Gesellschaften. Erinnerungen. Essen: Klartext, pp. 63-82.

Pollack, Detlef \& Pickel, Gert 1998. Die ostdeutsche Identität - Erbe des DDR-Sozialismus oder Produkt der Wiedervereinigung? Die Einstellung der Ostdeutschen zu sozialer Ungleichheit und Demokratie. Aus Politik und Zeitgeschichte, Nos. 41-42, pp. 9-23.

Reuter, Julia 2002. Ordnungen des Anderen: Zum Problem des Eigenen in der Soziologie des Fremden. Bielefeld: Transcript-Verlag.

Richter, Stefan 1993. Für Lenin ist es in Wünsdorf längst nach zwölf: Nach dem Abzug der Russen steht eine 2 700-Seelen-Gemeinde vor dem Problem, einen Militärriesen zu zivilisieren. Berliner Zeitung, September 4.

Sabrow, Martin 2012. 'Fußnote der Geschichte', 'Kuscheldiktatur' oder 'Unrechtsstaat'? Die Geschichte der DDR zwischen Wissenschaft, Politik und Öffentlichkeit. In: Katrin Hammerstein \& Jan Scheunemann (eds.) Die Musealisierung der DDR: Wege, Möglichkeiten und Grenzen der Darstellung von Zeitgeschichte in stadt- und regionalgeschichtlichen Museen. Berlin: Metropol-Verlag, pp. 13-24.

Sabrow, Martin 2014. Die DDR zwischen Geschichte und Gedächtnis. In: Christian Ernst (ed.) Geschichte im Dialog: DDR-Zeitzeugen in Geschichtskultur und Bildungspraxis. Schwalbach: Wochenschau-Verlag, pp. 23-37.

Satjukow, Silke 2004. Sowjetische Streitkräfte und DDR-Bevölkerung: Kursorische Phänomenologie einer Beziehungsgeschichte. In: Hans Ehlert \& Matthias Rogg (eds.) Militär, Staat und Gesellschaft in der DDR: Forschungsfelder, Ergebnisse, Perspektiven. Berlin: Links, pp. 225-249.

Satjukow, Silke (ed.) 2005. 'Die Russen kommen!' Erinnerungen an sowjetische Soldaten 1945-1992. Erfurt: Landeszentrale für politische Bildung Thüringen.

Satjukow, Silke 2008. Besatzer: 'die Russen' in Deutschland 1945-1994. Göttingen: Vandenhoeck \& Ruprecht.

Satjukow, Silke 2009. Die 'Freunde'. In: Martin Sabrow (ed.) Erinnerungsorte der DDR. München: Beck, pp. 55-67.

Schwelien, Michael 1991. Lieber reich als ruhmreich: Nichts fürchten die Sowjetsoldaten mehr als den raschen Marschbefehl nach Hause. Die Zeit, July 5. Available at http://www.zeit.de/1991/28/lieber-reich-als-ruhmreich, last accessed on August 24, 2017.

Sörensen, Marie L. S. \& Viejo-Rose, Dacia (eds.) 2015. War and Cultural Heritage: Biographies of Place. Cambridge: Cambridge University Press. Available at http://www.academia.edu/11723150/War_and_Cultural_Heritage_Biographies_ of_Place, last accessed on August 24, 2017.

Sowjettruppen 1990 = Sowjettruppen: Nerz und Matsch. Der Spiegel, December 24. Available at http://www.spiegel.de/spiegel/print/d-13503061.html, last accessed on August 24, 2017.

Staatsfeiern 1994 = Staatsfeiern: Die unendliche Geschichte. Der Spiegel, March 14. Available at http://www.spiegel.de/spiegel/print/d-13685769.html, last accessed on August 24, 2017. 
Thoß, Bruno (ed.) 2007. Die Geschichte der NVA aus der Sicht des Zeitzeugen und des Historikers. Potsdam: Militärgeschichtliches Forschungsamt.

Tuchman, Barbara W. 1964. Can History Be Served Up Hot? New York Times, March 8. Available at http://www.nytimes.com/1964/03/08/can-history-be-served-up-hot. html, last accessed on August 24, 2017.

Tunbridge, John E. \& Ashworth, Gregory J. (eds.) 1996. Dissonant Heritage: The Management of the Past as a Resource in Conflict. Chichester: Wiley.

Unsere Leute 1993 = Unsere Leute sind aggressiver: Spiegel-Interview mit Sicherheitsoffizier Anatolij Olejnikow über die GUS-Kriminalität in Deutschland. Der Spiegel, June 21. Available at http://magazin.spiegel.de/EpubDelivery/spiegel/pdf/13683264, last accessed on August 24, 2017.

Veblen, Thorstein 1899. The Theory of the Leisure Class: An Economic Study in the Evolution of Institutions. New York: Macmillan. Available at http://moglen.law. columbia.edu/LCS/theoryleisureclass.pdf, last accessed on August 24, 2017.

Welzer, Harald 2002. Das kommunikative Gedächtnis: Eine Theorie der Erinnerung. München: Beck-Verlag.

Wieschollek, Stefan 2005. Ein totgeborenes Kind in Wünsdorf-Waldstadt? Probleme der Umnutzung des ehemaligen Hauptquartiers der Westgruppe der Truppen zur zivilen Kleinstadt. Bonn: Bonn International Center for Conversion. Available at https://www.bicc.de/uploads/tx_bicctools/paper49.pdf, last accessed on August 24, 2017.

Wrochem, Oliver von 2003. Die sowjetischen Besatzer: Konstruktionen des Fremden in der lebensgeschichtlichen Erinnerung. In: Jan C. Behrends \& Thomas Lindenberger \& Patrice G. Poutrus (eds.) Fremde und Fremd-Sein in der DDR. $\mathrm{Zu}$ historischen Ursachen der Fremdenfeindlichkeit in Ostdeutschland. Berlin: Metropol, pp. 57-74.

Zwischenbilanz 1994 = Zwischenbilanz des russischen Abzugs: Verzögerungen beim Wohnungsbau/Zunehmende Kriminalität. Frankfurter Allgemeine Zeitung, January 26. Available at http://www.genios.de/presse-archiv/inhalt/ FAZ/19940126/4/f-a-z-frankfurter-allgemeine-zeitung.html, last accessed on August 24, 2017.

\section{INTERNET SOURCES}

Bücher und Bunkerstadt Wünsdorf. Bücherstadt-Tourismus GmbH. Available at www. buecherstadt.com, last accessed on August 23, 2017.

Die Waldstadt Wünsdorf. Available at http://www.waldstadt-wuensdorf.de, last accessed on August 23, 2017.

Militärparade in Wünsdorf 1994. Available at https://www.youtube.com/ watch?v=ShYQFoh2290, last accessed on August 23, 2017.

Stadt Zossen. Available at www.zossen.de, last accessed on August 23, 2017.

$V K$ (social medium). Available at https://new.vk.com/wunsdorf, last accessed on August 23, 2017.

Wunsdorf, DDR-Posledniaia osen' / / Letzten Herbst. Available at https://www.youtube. com/watch?v=LEOeTtfCigo, last accessed on August 23, 2017. 


\title{
GERMAN DEMOCRATIC REPUBLIC OF THE 1970s-1980s THROUGH THE EYES OF SOVIET OFFICERS (ORAL STORIES)
}

\author{
Evgeny V. Volkov \\ Department of Russian and Foreign History \\ South Ural State University, Russia \\ e-mail: evgeny-volkov@mail.ru
}

\begin{abstract}
This article is based on eight interviews with former officers who served in the Group of Soviet Forces in Germany (after 1989, the Western Group of Forces) during the $1970 \mathrm{~s}$ and $1980 \mathrm{~s}$. The aim of this research is to analyze the content and speech characteristics of Soviet officers' oral testimonies about their service in the German Democratic Republic (GDR). The main task of this research is to study information about the conditions of service of Soviet officers in the GDR, identifying key images of East Germany in the views of the respondents, and describing individual and general features of the respondents' discourse. The reminiscences about the GDR presented in the interviews reveal the different attributes of social memory of the former Soviet military personnel, who usually had positive stories to tell about their years spent in the country. The discourse of the respondents who were interviewed had some common features inherent in the identity of a "military man": efficiency and clarity of speech, emphasizing the positive characteristics of the Soviet Army, and the absence of criticism of the Soviet authorities. At the same time, many memories included negative evaluations of the policies of President Boris Yeltsin and feelings of nostalgia for life in the Soviet Union.
\end{abstract}

Keywords: German Democratic Republic, Group of Soviet Forces in Germany, intercultural communication, oral stories, Soviet officers, Western Group of Forces

\section{THE FORMULATION OF THE ISSUE}

Intercultural communication, the result of constructed representations about the people and cultures of other countries, helps to form opinions and evaluations and influences styles of behavior. The history of the Soviet troops in East Germany from 1945 to 1994 has recently become the subject of intense study for a number of German historians (Kowalczuk \& Wolle 2001; Satjukow 2008; Hoffmann \& Stoof 2008; Gehrke 2008; Lohmann 2010; Büttner \& Morre 2014). ${ }^{1}$ Modern Russian historiography on the subject is not as extensive and 
includes only a few works mainly created as political history and usually based on personal memoirs (Burlakov 1994; Boltunov 1995; Basistov \& Ezhova 2005). However, in my opinion, the most productive research can be undertaken by means of a historical-anthropological approach that addresses not only specific events and impressions of those events, but also the thoughts and emotions of people, their life practice. The most promising direction in the field of history is the study of intercultural communication (Satjukow 2003; Zdravomyslov 2003; Vershinin 2003; Tikhomirova 2008).

In this research, which is based on oral history interviews and several published memoirs, journalistic texts and documents of the Group of Soviet Forces in Germany (the Western Group of Forces), the following questions are raised: What were the conditions of service of Soviet officers in the German Democratic Republic (GDR)? What were the forms of international communication between the Soviet officers and Germans? What images of East Germany remained in the memories of Soviet officers? How did service in the GDR influence the opinions of Soviet officers?

I think such research will increase knowledge in the study of representations constructed by Soviet officers about East Germany during the Cold War.

The oral stories can be considered memory markers about the past. According to the theory of the German researchers Jan and Aleida Assmann, "collective memory" is a group of representations about the past, captured in images that are constructed in the form of social and cultural memory. Social memory is based on the communication of people as witnesses and contemporaries of the recent past (Assmann 2004: 14-91; Assmann 2014). From this point of view, oral stories are social memories as representations of a certain group of people about their recent past.

\section{HISTORICAL CONTEXT}

Relations between the Union of Soviet Socialist Republics (USSR) and the GDR were built in a more intensive manner than in other socialist countries of Eastern Europe. One major factor was the overall experiences, both negative and positive, of World War II (Eimermacher \& Volpert 2010). Military cooperation, in addition to economic and cultural cooperation, was most ambitious in the GDR. The biggest deployment of Soviet troops from 1945 to 1994 was in the territory of the GDR. During a period of almost fifty years 540,000 officers, 180,000 warrant officers, and 5,380,000 soldiers and sergeants served in the Group of Soviet Forces in Germany. We must add 416,000 workers and employees, as well as 1,500,000 members of officers' families. As a result, more than eight million Soviet citizens lived, served, and worked in East Germany from 1945 
to 1994 (Boltunov 1995: 100). The Group of Soviet Forces in Germany was like a small country, with its own supply system, equipment repair, schools, rest homes, and even a radio station and a theater (Basistov \& Ezhova 2005: 175).

The period from the second half of the 1960s to the middle of the 1980s was characterized by a great deal of activity in the relations between the Soviet Union and the GDR. At that time the Soviet leadership began giving more freedom to the GDR. The semi-enemy image of East Germany in Soviet propaganda gradually became more positive after the construction of the Berlin Wall (1961) (Vatlin 2009: 186-187).

We can point to a number of agreements signed between the Soviet Union and the GDR as important examples of cooperation. In 1969 a visa-free regime was introduced between the two countries (Zemskov 1981: 245-248). SovietGerman relations were even confirmed at the level of the new Constitution of the GDR in 1974, which said that East Germany "forever and forever is an ally of the Soviet Union" (Faulenbach 2009: 94). Perhaps this was the reaction of the GDR's leadership to the Kremlin's giving more freedom to East Germany.

On October 7, 1975, the agreement "Friendship and Mutual Assistance between the USSR and the GDR" was signed. On September 3, 1978, the joint space flight of Vladimir Bukovsky and Sigmund Yen ended, the latter being the first German to fly in space as part of the Soviet Intercosmos program. At the end of the 1970s several Soviet military divisions left East Germany (Boltunov 1995: 89).

In 1976, at the 11th Congress of the Socialist Unity Party of Germany, the aim was established to construct a developed socialist society as in the Soviet Union. At this point in the relationship between the two countries, an equal union was established, replacing the "teacher - disciple" scheme (Vershinin 2003: 348). However, beginning in the middle of the 1980s, the attitude of the Germans to Soviet citizens who were in their country became more negative and even hostile (Zdravomyslov 2003: 378). The GDR leadership reacted negatively to the policy of Perestroika introduced in the Soviet Union. The Socialist Unity Party of Germany was more conservative and orthodox than the Communist Party of the Soviet Union (Faulenbach 2009: 94). However, most of the GDR's population apparently supported the new Soviet policy.

\section{RESPONDENTS}

There are not many published memoirs of Soviet officers who served in the GDR, though several Internet sites focus on the life of Soviet military men in East Germany (e.g. Gruppa Sovetskikh voisk v Germanii; Bernau v/ch 47545). My interest is in new sources of information, and therefore I used oral stories 
for the research, together with published memoirs. The interviews that became the basis for this research were conducted in the Chelyabinsk and Kurgan regions of the Russian Federation from April 2011 to May 2014. These interviews were thematic and contained a list of questions that became the main structure for interviewing respondents. The interviewees, former officers, were selected randomly. They told their oral stories at home or at the Russian History Department of South Ural State University. Two people took part in each dialog: a researcher and a respondent. The conversation usually lasted one hour.

Eight respondents shared their reminiscences about their service in the GDR. They were retired Soviet officers: four colonels, two lieutenant colonels, one major, and a captain. The distribution of the interviewees according to their specialization was as follows: four military drivers, two gunners, one tank troop, and one border guard. According to their social origin, four of the respondents considered themselves to be of white-collar family backgrounds, while the others regarded themselves as descendants of blue-collar workers. Almost all of the respondents were born in the Urals or in Siberia, and only one in the Volga Region. The average age of the respondents at the time of the interviews was sixty years. Seven of them had served in the GDR in the 1970s and 1980s, immediately after graduation from military schools, and one served in East Germany when he was older, in the rank of colonel. They were in the GDR for five years, except for one respondent, who was there for three years. A reduced service period took place, as a rule, if an officer was not married or received a bad evaluation. ${ }^{2}$

The speaking style of many respondents was clear and loud, typical of those used to giving orders. As a rule, these people were conservative. They regretted the collapse of the USSR; their words reflected nostalgia for the Soviet past and negative attitudes to Michael Gorbachev's liberal policy, as well as to Boris Yeltsin. They said little about the shortcomings of the Soviet Army, and more about the army's achievements and positive sides.

Such rhetoric can be explained by the fact that each social group needs "legitimation", which is achieved, among other ways, by drawing on certain shared rules and principles of communication. Such "legitimation" is carried out, according to the German philosopher Jürgen Habermas, on two levels. Firstly, the rules and principles of the "legitimation" construct a certain system of values. Secondly, this set of rules and principles serves as a basis for distinguishing between "us" and "them": those who adhere to these rules, and those who reject them (Habermas 2015 [2011]; Sladkova 2015: 13-14, 18-19). 


\section{FEATURES OF SOVIET OFFICERS' SERVICE IN THE GDR}

The Group of Soviet Forces in East Germany (up to March 24, 1954, the Group of Soviet Occupation Forces in Germany) was established on June 9, 1945, on the basis of military units of the 1st Belorussian Front, with headquarters in Potsdam. In 1946, the headquarters moved to Wünsdorf. At first the Group consisted of nine land and one aircraft army, and by the early 1950s this was reduced to seven armies. In 1979 one army withdrew from East Germany. It should be noted that beginning in the 1960s the Group of Soviet Forces in Germany was armed with rockets with nuclear warheads (Basistov \& Ezhova 2005: 173).

The Group of Soviet Forces in Germany was subordinated to the Commander of the Western Direction and cooperated with the National People's Army of the GDR. By the end of the 1980s, Soviet troops in the country amounted to nineteen divisions (eleven tank and eight motorized infantry). There were about 337,000 soldiers, more than 4,000 tanks, 7,500 armored vehicles, 3,600 artillery systems, 940 airplanes, and 785 helicopters. The troops were located on 777 bases; they had 3,422 training centers and shooting ranges, 47 airfields, and 5,269 depots and warehouses. In 1989, under the conditions of crisis in the Soviet system, all Soviet troops were renamed the Western Group of Forces, and began a gradual withdrawal from the territory of the GDR, which ended on August 31, 1994 (Feskov \& Kalashnikov \& Golikov 2004: 15).

Usually Soviet officers got the chance to serve in East Germany due to a tsarist era tradition that the Soviet Army continued. The highest achieving graduates of the military schools received first choice in place of the service. ${ }^{3}$ Many of the respondents, having excellent educational results, chose the GDR as their initial duty station.

What determined their choice? According to those interviewed, many of them dreamed about military service for nastoiashchikh muzhchin ('real men'). In contrast to the Soviet Union, where there were many incomplete military units and military exercises were seldom conducted, the Group of Soviet Forces in Germany engaged in diverse high combat training because they were stationed in the immediate vicinity of the enemy - the troops of NATO. ${ }^{4}$

Contemporary propaganda bulletins published by the political management of the Group of Soviet Forces in Germany served as constant reminders to Soviet soldiers that they were "the sentinels of the front line", on the border with the "militaristic Western World" (Liubit' rodinu 1960; Na boevom postu 1975; XXIV s"ezd KPSS 1971).

In addition, lieutenants could opt to serve in the GDR in order to boost their military careers. As a rule, officers who had served in the Group of Soviet Forces 
in Germany, upon their return to the Soviet Union received appointments one degree higher than they would have under normal circumstances (Basistov \& Ezhova 2005: 174). Yet, none of the respondents mentioned these advantages when explaining their aspirations and motives for serving in East Germany.

Material interests were another reason for the service in East Germany. Soviet officers abroad received a double salary, one in German marks at the place of service, and the other in Soviet rubles deposited in a savings account back in the Soviet Union. At the same time, it was possible to buy and then take home commodities that were difficult or impossible to find in the Soviet Union. There was an unwritten rule that during their final year of service in the GDR, Soviet officers bought many such things. ${ }^{5}$

Upon entering East Germany, the Soviet administration usually exchanged thirty rubles for GDR marks (ninety marks at the rate of 1976). In addition, each new officer received 200 marks during the first month. ${ }^{6}$ The average monthly salary of junior officers (lieutenants and senior lieutenants) was about 700 GDR marks, and they also received 300 marks to support the accompanying family. Service in the GDR was thus economically very beneficial. ${ }^{7}$ At the time, the average monthly salary in the Soviet Union was around 150 rubles or 450 GDR marks. In addition, many people certainly wanted to go abroad, to see other countries and learn about other cultures. As one respondent put it, "I wanted to see the West".

Before the trip to East Germany almost all of the respondents, being young officers, received preliminary instruction from political officers on how to behave abroad in order not to undermine the honor and dignity of Soviet citizens. Officers were strongly advised to avoid shopping and to control their wives, to abstain from contacts with Germans, and to obey their superiors. Single officers received strict commands not to pay frequent visits to restaurants and Gaststätte, and were instructed to drink moderately. ${ }^{9}$

It is worth noting that officers had to turn in their passports after their arrival in the GDR. When moving around in East Germany, they only had their identity papers with them. ${ }^{10}$ This measure was aimed at restricting Soviet officers' entry to East Berlin, where there were plenty of foreigners. Any Soviet citizen with a foreign passport could move on to West Berlin, which was considered a hostile territory. However, group trips of senior officers to West Berlin were allowed once a month. At first, such groups had to be accompanied by a command retinue, but by the 1970s these "bodyguards" were no longer required (Tolmachev 2010: 338-339).

There was a counter-intelligence officer in every military unit. He was usually called a "kgbshnik", ${ }^{11}$ referring to the Komitét gosudárstvennoi bezopásnosti (Committee for State Security) or KGB, the main security agency of the Soviet 
Union. Counter-intelligence officers had the task of monitoring the behavior and "illegal talks" of Soviet soldiers and officers, and interrogated people who had violated orders. One respondent noted that the counter-intelligence officer "always kept to himself in a group of officers. ... Usually he did not go to meetings with higher military authorities. But I got the impression that he knew everything". ${ }^{12}$ One of the most common punishments was premature departure to the Soviet Union for further service in northern garrisons. As a rule, such a situation undermined a successful future military career.

Soviet troops in the GDR were located in separate military camps near German settlements. Such military bases either had long histories, having been used before by troops of the German Empire or the Wehrmacht, or had been built only recently on the basis of German model projects. ${ }^{13}$ One of the respondents expressed his awe of the old military German buildings: "Amazing, they did everything on the highest level". ${ }^{14}$ Some homes occupied by the Soviet military had stucco and sculptures with Nazi symbols that had to be covered.

All military garrisons were surrounded by high fences, which were usually painted green, leading Germans to informally call the Soviet troops RussischGrün or "Green Russians" (Basistov \& Ezhova 2005: 179, 181). Practically the entire period of service of Soviet officers in the GDR was filled with intensive military training. Regimental, divisional, and army training exercises took place annually. Twice a year, usually for ten to twelve days, the Group of Soviet Forces in Germany conducted training with the participation of Polish and GDR troops (ibid.: 175). General Valentin I. Varennikov, who served in the GDR in a high command post, explained:

The Group of Soviet Forces in Germany was actually a school for preparing many staff members in all units of the Armed Forces of the USSR. Military training was carried out by the Group of Soviet Forces in Germany, together with the forces of the National People's Army of the GDR, which was tense and took place all year round. (Varennikov 2001: 4)

One of the respondents said: "We had a very fun life and we were not bored. There was an increase in the alarm level two or three times a week...". ${ }^{15}$ Every morning started with sports activities, and on Sunday all military units ran cross-country courses. Then there were theoretical and practical trainings for military people. The whole schedule was strict. ${ }^{16}$

Soldiers and sergeants, as a rule, arrived at the Group of Soviet Forces in Germany well prepared for such demanding service, as they had already passed the selection and primary military training in the USSR (Basistov \& Ezhova 2005: 174). The national composition of Soviet troops was multi-ethnic, including representatives of the many nations of the Soviet Union (Fig. 1). However, 


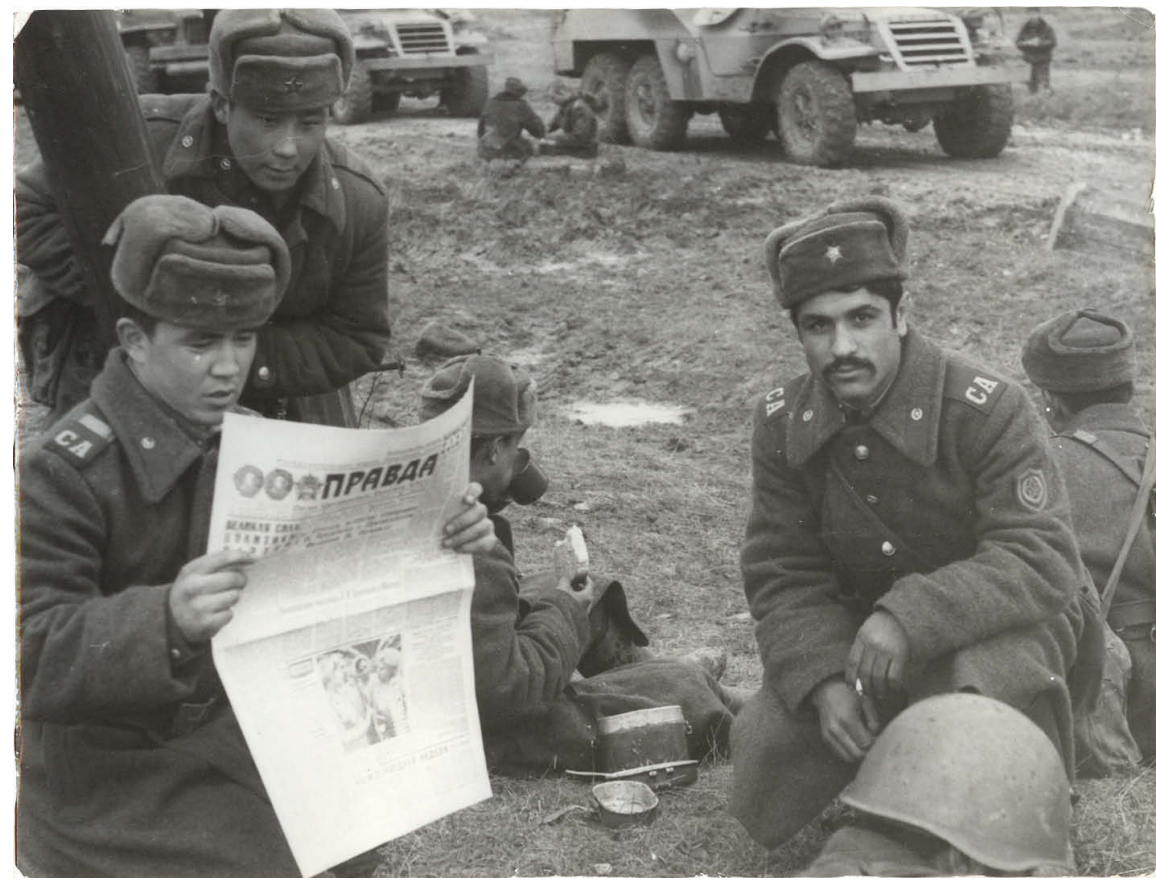

Figure 1. The multi-ethnic Soviet Army in the 1970s.

Photograph from the private collection of a respondent.

the largest groups were Russians and Ukrainians, followed by Armenians, Georgians, Azerbaijanis, Chechens, Tajiks, Uzbeks, and Latvians. ${ }^{17}$

Off-duty officers could go outside the military bases and communicate with the German population. Yet, this was discouraged and it was forbidden to move around in civilian clothes outside the bases (Basistov \& Ezhova 2005: 185). ${ }^{18}$ However, sometimes Soviet officers ignored it (Fig. 2). Individual trips by soldiers and sergeants in the GDR were forbidden. Except for certain cases, they were always on the military bases.

As for dedovshchina ('hazing'), many respondents admitted that it had taken place, although they discussed it with reservations and minimized this negative phenomenon in the Soviet Army. They pointed out that much depended on the commanders and how they controlled their soldiers. ${ }^{19}$ This is confirmed by the memoirs of one of the sergeants who served in the Group of Soviet Forces in Germany from 1984 to 1986 . His book contains facts that highlight "hazing with a slight touch of criminality" (Luchkin 2014: 20-22, 36-37, 43, 88-91). But some narrators noted that dedovshchina was not present in their military units and, on the contrary, experienced soldiers "had taken over all the hard work" and 
Figure 2. A Soviet officer in his free time in the GDR in the 1970s. Photograph from the private collection of a respondent.

taught young soldiers. ${ }^{20}$ Because of hazing and for other reasons, there sometimes were cases of desertion and crime among Soviet soldiers. However, such incidents were quickly suppressed in active cooperation with the GDR police.

Some respondents pointed out that some Soviet officers fled to the West, taking with them secret documents. But these incidents took place mainly at the end of the 1980s and the beginning of the $1990 \mathrm{~s}$, when there was a crisis in the Soviet system and in the

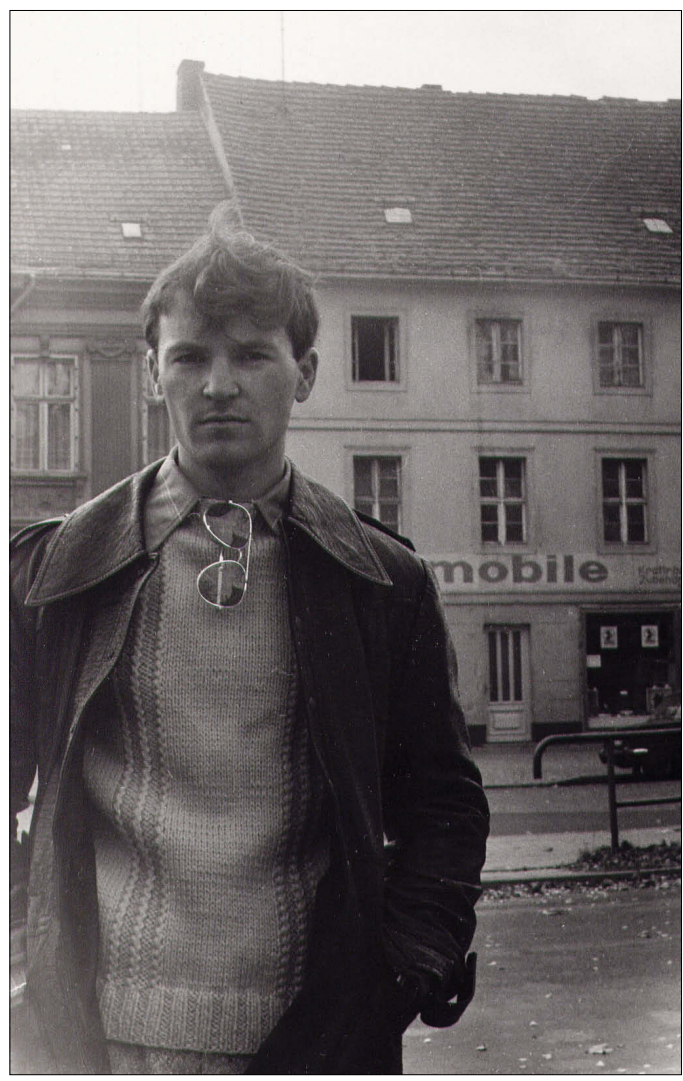
Soviet Army. ${ }^{21}$

Soviet officers usually spoke little about family life during their service in the GDR. Single lieutenants sought opportunities to get married quickly because this was a condition for extending their service abroad. There were also cases of adultery, but there were almost no divorces because they could lead to being sent back to the USSR. ${ }^{22}$ In general, many of the respondents had positive reminiscences about their service in East Germany. They had real combat training, improved their financial status, and got some knowledge of the German culture and the everyday life of Germans.

\section{THE FORMATS OF INTERCULTURAL COMMUNICATION}

According to the reminiscences of the interviewed Soviet officers, most of them were interested in getting to know East Germany, a country that was previously unknown to them. Only one of the interviewees was afraid to encounter Germans, who in Soviet war films were shown more as enemies than friends. ${ }^{23}$ 
Soviet military personnel could get information about Germans and their culture via formal channels, as well as informally, by engaging in direct contact with them. In the official discourse, firstly, there were propaganda texts. For example, beginning in 1961, every year a large collection of materials and documents about the GDR, designed specifically for Soviet officers, was published. It contained information about the economy, politics, and culture of the GDR, the main decisions of the Socialist Unity Party of Germany, excerpts from agreements between the Soviet Union and East Germany, and information about the National People's Army (Basistov \& Ezhova 2005: 179; Zhdanov 1975: 126).

In addition, twenty divisional newspapers and the central newspaper Red Army were periodically published in the Group of Soviet Forces in Germany. There was the radio station Volga, and a TV center was started in 1979 (Burlakov 1994: 228-229).

"The Room of German-Soviet Friendship" was another place where Soviet soldiers could find official information about the GDR. As a rule, such a room existed in each military unit and was used to display posters, photographs, albums, books, and pennants. It showcased everything about the GDR and friendly relations between Soviet citizens and Germans. Similar rooms were created in the military units of the National People's Army of the GDR. ${ }^{24}$

Informal communication with Germans took place mainly in shops, restaurants, Gaststätte, and in industries. Often, Soviet military men helped with agricultural labor on German cooperatives. ${ }^{25}$ German civilian builders worked on Soviet military camps and bases. A separate GDR construction company fulfilled the orders of the headquarters of the Group of Soviet Forces in Germany (Basistov \& Ezhova 2005: 176).

As mentioned above, joint military training exercises took place between the Soviet Army and the National People's Army of the GDR. There also were joint formal meetings and sports competitions (Khurbaev 1981: 52). ${ }^{26}$ Some officers pointed out the very high level of the Military Forces of the GDR (Varennikov 2001: 52-53). Soviet officers often went on excursions with their families and soldiers to see the most famous sights of East Germany.

Communication between the Soviet military and Germans was eased by the fact that many residents of East Germany knew the Russian language at the basic or intermediate level. One respondent said:

But I was convinced that language knowledge for me was not necessary, because the Germans already had great experience with our Russian people, and they perfectly understood everything we needed. And at any store, any Gaststätte, any restaurant, at the cashier, anywhere, if they saw that you were Russian, they were always ready to help. ${ }^{27}$ 
Many Germans were perceived as very friendly by Soviet military personnel. ${ }^{28}$ But perhaps this kindness was false and many Germans were simply fearful of the military power of the USSR. ${ }^{29}$

Soviet officers were not allowed to use their real last names in their dealings with Germans. Conversations with Western military personnel or with officers of foreign military missions in the GDR were strictly forbidden (Basistov \& Ezhova 2005: 186-187).

Although Soviet officers were not allowed to visit East Berlin on their own, there were a variety of loopholes in this prohibition. The interviewees had been there off duty and in civilian clothes and had seen many sights, including the Berlin Wall. ${ }^{30}$ Members of the Soviet military were advised not to leave their military units on days associated with the history of the Third Reich. One of these dates was April 20, the birthday of Adolf Hitler. On this day, as on other "Nazi holidays", noisy groups would gather in Gaststätte and restaurants, increasing the likelihood of acts of aggression against Soviet military personnel (Luchkin 2014: 201). ${ }^{31}$ One respondent remembered that a certain Gaststätte near his military base was notorious for being a "fascist place", as many former SS men frequented it. Of course, Soviet officers would not go there. ${ }^{32}$ According to the testimony of another respondent, there was hostility from German youth. One incident took place in the late 1970s, on the eve of Victory Day (May 9), when young German men defiled a cemetery for Soviet soldiers, throwing away wreaths and flowers, and painting swastikas on several monuments. ${ }^{33}$ Another interviewee recalled that during the second half of the 1980s the most negative reactions towards Soviet troops would come from German youth, although most young people were loyal to the Soviet military. ${ }^{34}$ But this was just the personal opinion of a former Soviet officer.

\section{IMAGES OF EAST GERMANY}

Certain images and recurrent tropes dominated respondents' oral accounts of East Germany. Firstly, German nature: well-groomed forests, fields and gardens, fruit trees growing everywhere along the roads. As one of the narrators noted, it was forbidden to pick fruit in public places. Exceptions were made only for pregnant women and children, and the police monitored the fruit trees closely. But sometimes Soviet soldiers would slyly drive their military trucks in such a way that the trucks would brush against the trees, causing fruit to fall into their vehicles. ${ }^{35}$

The forests in Germany, in comparison with the Soviet Union, were very clean, with no dead trees in sight and everything in perfect order. There were 
many living creatures, for example, rabbits and pheasants. Soviet officers often went into the forests near military units and hunted illegally. Sometimes it was possible to kill a wild boar. In order to fish on the rivers, lakes, and reservoirs of the GDR, one had to have a special permit, and even then one could only use fishing poles. However, Soviet officers and soldiers would fish with nets, sometimes during military trainings. ${ }^{36}$

Another recurrent image of Germany in the narratives of Soviet military men involved train stations. As a rule, Soviet officers would arrive in the GDR by train and they also often used trains to move around the country for service and personal travel. German train stations emerge from respondents' accounts as examples of German order. Many respondents pointed out the cleanliness and perfection of stations, the clarity of the whole system, and punctuality of the trains. For example, the Leipzig train station made a big impression on one of the respondents. ${ }^{37}$ Another person elaborated on the efficient work of the train station in Frankfurt on Oder. ${ }^{38}$ Some people were surprised that there were no sleeping cars on German trains. Typically, these trains were small, with only a few carriages. Soviet citizens would refer to them as "trams". The whole rail transport system was very different from that in the Soviet Union.

Another important attribute of Germany was the highway. Military vehicles were prohibited on such roads, but this rule was often violated. During military training exercises, Soviet convoys mostly used motorways to save time. ${ }^{39}$ This was illegal, but local German authorities looked the other way. The respondents noted the high quality of German roads built from gravel and asphalt. The signage was colorful and the roads were marked clearly. In general, it was hard to get lost on the roads of East Germany. Even so, the officers still bought and used road maps. ${ }^{40}$

Almost all of the respondents mentioned the main cultural attractions of the GDR: the Dresden art gallery, Goethe's museum in Weimar, the Sanssouci palace in Potsdam, the Brandenburg gate in Berlin, and the Leipzig zoo. They had visited these sights either alone or with their families. They also mentioned the former concentration camps Buchenwald, Sachsenhausen, and Ravensbrück. Soviet military personnel often took part in official ceremonies for memorials dedicated to Soviet soldiers who had fallen in Germany during World War II. ${ }^{41}$ This was, of course, due to the historical policy of Soviet authorities and the anti-fascist rhetoric of the socialist German state (Fig. 3). Many of the excursions organized for military personnel were to memorial places connected with the history of the Third Reich and the Holocaust. For example, soldiers and sergeants of the Group of Soviet Force in Germany would pay collective visits to museums built on the sites of German concentration camps. 
Figure 3. Soviet officers during a military parade in the 1970s. Photograph from the private collection of a respondent.

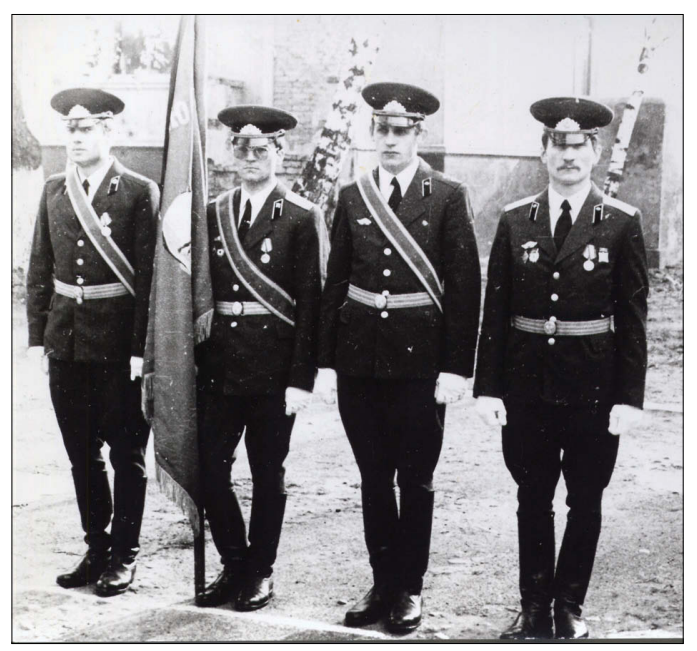

Another very significant image of the GDR in the minds of Soviet people concerned the shops and the abundance of goods, which stood in stark contrast to the situation in the USSR. The respondents talked about this in great detail. They noted the courtesy and friendliness of merchants, and the high level of service. German products and those of other foreign countries were of high quality, especially shoes and clothing. All of the products were available to officers of the Group of Soviet Forces in Germany and their family members. ${ }^{42}$ Some officers, according to one of the interviewees, were obsessed with shopping. ${ }^{43}$ At the same time, some Soviet people were amazed that Germans, who had been defeated in World War II, lived better than the Soviet victors. ${ }^{44}$

German cuisine was not particularly extolled by respondents. One of them negatively commented on "heavy" dishes and soups, which were more like sauces. ${ }^{45}$ However, many noted the excellent taste and variety of sausages with different spices. They also stressed the high quality of German beer, of which there was great variety. Under the influence of German cuisine, some officers even partially varied their diets while living in the GDR. For example, they drank more beer and Coca-Cola instead of the traditional tea. ${ }^{46}$

Formal and informal interactions with Germans led Soviet officers to form certain impressions of Germans and their culture. The respondents noted that Germans worked effectively and relaxed well. One of the narrators said that he heard from a German: "You live to work, and we work to live". ${ }^{47}$

The daily routine of the Germans was unusual for Soviet citizens. On the eve of working days, early in the evening, the streets and town squares were quiet. Germans stayed at home and went to bed early, because the next day 
they had to get up very early to go to work. At the same time, the working day ended at $4 \mathrm{pm}$, leaving Germans with plenty of free time before the evening. ${ }^{48}$

Since the respondents were men, they paid special attention to German women. They pointed out, for example, that Germans' attitudes towards sexual relations differed from that of the Soviet people. German women were said to be more relaxed in intimate relationships. The movies on the big screen and on TV very often showed erotic scenes, especially at night. While this might have been quite commonplace for Germans, it was unusual for Soviet citizens..$^{49}$ One of the respondents said that some Soviet citizens used the services of prostitutes.$^{50}$ Others spoke about the unenviable fate of officers who married German women, because this was detrimental to their military careers. ${ }^{51}$

A memorable figure representing East Germany was the policeman. The interviewees described him as a person the population was fond of, whom all inhabitants obeyed and who was always there to help. This situation contrasted sharply with the image of the police officer in the USSR. In the GDR, there was an efficient system whereby people could report information to the police and those who had committed crimes were, as a rule, quickly detained. In emergency situations, police patrols went out with dogs. Deserters from the Group of Soviet Forces in Germany were very often found by the German police. However, Soviet security police usually did not recommend that the Soviet military ask the German authorities for help..$^{52}$ The army did not inform the authorities of the GDR about criminals among Soviet soldiers. In their opinion, this could damage the prestige of the USSR. According to the interviewees, the police of the GDR consisted of specially selected and well-trained people. One respondent even said: "At that time people said that to become a policeman was as difficult as to fly into space". 53

Personnel of the National People's Army were closest in profession and spirit to Soviet officers (Fig. 4). Soviet and East German troops met through military training exercises and official celebrations, as well as sports competitions. GDR soldiers were attractive in the eyes of the respondents. They were usually dressed immaculately, clearly followed orders, and knew about complex military details. Even the equipment, weapons and uniforms of the National People's Army were aesthetically pleasing. The soldiers and officers of the GDR army seemed to have much more free time. After a day of work, they could go home and stay there till morning. ${ }^{54}$

These images of another country have been preserved in the memories of former Soviet military personnel, and we can assume that over time the memories have not been heavily distorted in the process of constructing reminiscences and biographical narratives. 


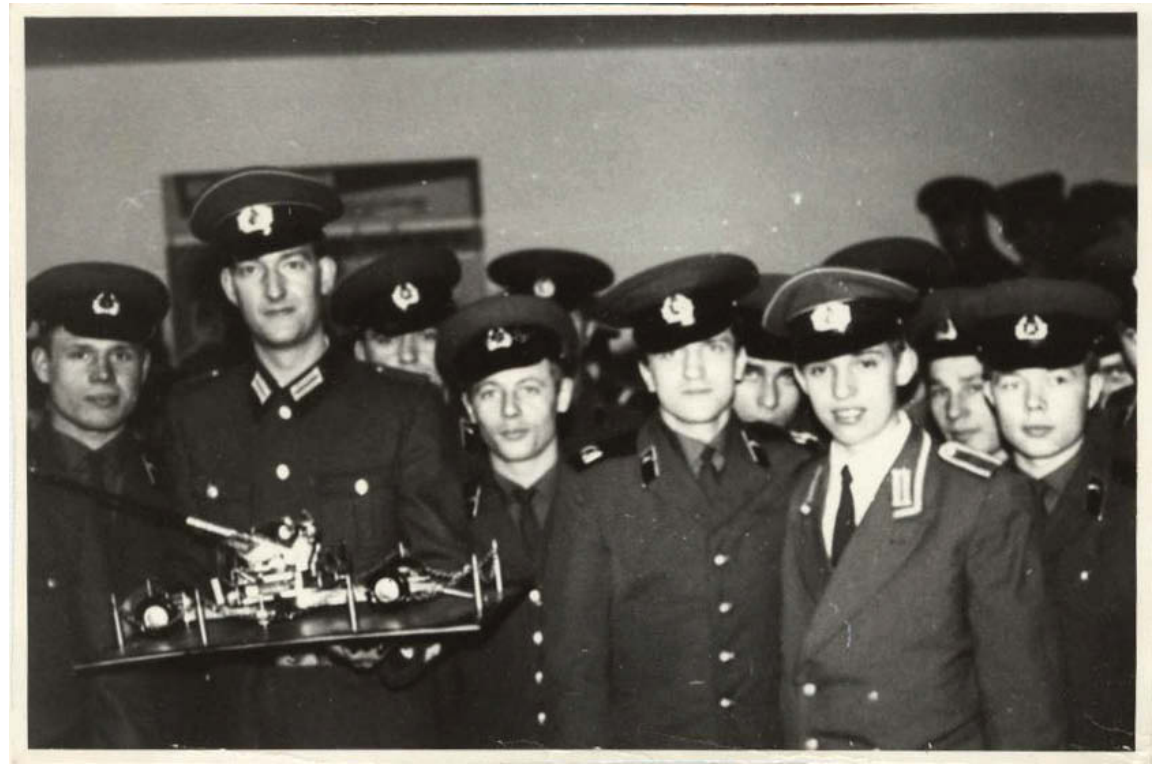

Figure 4. A meeting of soldiers from the USSR and the GDR in the 1970s. Photograph from the private collection of a respondent.

\section{CONCLUSION}

Oral stories told by eight former Soviet officers provided information on the life conditions of the Soviet military in the GDR and their views about the culture of East Germany. At the same time, these interviews demonstrated the attitudes and rhetoric of the respondents. They often emphasized the high efficiency of the Soviet Army, despite some of its shortcomings. They still believed in the positive mission of the Soviet Union in Eastern Europe during the Cold War. These oral stories included nostalgia for bygone times and youth in the "cozy and comfortable" ( $v$ uiutnoi i komfortnoi) East Germany. Images of Germans were often not the images of friends, but of people of another culture. However, the collective image of the "Other" constructed in the interviews was closer to the image of a friend than that of an enemy. But still, it was the image of a different culture. Representations of East Germany in these oral stories do not differ radically from written memoirs created by former officers and soldiers who served in the GDR (Tolmachev 2010).

These Soviet officers did not become active supporters of the democratic changes initiated in the Soviet Union during Perestroika, towards the end of the $1980 \mathrm{~s}$. On the one hand, there was the effect of the corporate conservatism 
of the military environment, and, on the other hand, these people saw in East Germany what might be called "socialism with a human face". The memories of the GDR, presented in oral stories, reveal the different attributes of the life world of former Soviet military personnel, which usually included positive biographical reminiscences about years spent in this country. They saw the Western world and learned something about Western culture. Many of them began their successful military careers in the GDR. It was a time of youth and the beginning of family relations. Their first children were born there. The families of these officers acquired many material goods in the GDR. The memories of these people included images of their service in the GDR, and on this basis they created a discourse about another country and a different culture. In many ways, these images were positive.

\section{NOTES}

1 See also the contribution by Christoph Lorke in this volume.

${ }^{2}$ Interview with Sh. V., May 2011.

${ }^{3}$ Interviews with K. G., April 2011, and Sh. V., May 2011.

${ }^{4}$ Interviews with A. S., November 2011, K. V., August 2011, and K. G., April 2011.

5 Interview with A. S., November 2011.

6 Interviews with K. G., April 2011, and A. S., November 2011.

7 Interview with S. V., May 2014.

8 Interviews with Sh. V., May 2011, and A. S., November 2011.

9 Interviews with K. G., April 2011, and A. S., November 2011.

${ }^{10}$ Interview with K. G., April 2011.

${ }^{11}$ Interview with K. V., August 2011.

${ }^{12}$ Interview with K. G., April 2011.

${ }^{13}$ Interviews with K. G., April 2011, K. V., August 2011, and Sh. V., May 2011.

${ }^{14}$ Interview with K. G., April 2011.

${ }^{15}$ Interview with A. S., November 2011.

${ }^{16}$ Interview with Sh. V., May 2011.

${ }^{17}$ Interview with K. G., April 2011.

${ }^{18}$ Interviews with K. G., April 2011, and Sh. V., May 2011. 
${ }^{19}$ Interviews with Sh. V., May 2011, K. V., August 2011, A. S., November 2011, and S. V., May 2014.

${ }^{20}$ Interview with E. V., December 2012.

${ }^{21}$ Interview with S. V., May 2014.

${ }^{22}$ Interview with K. V., August 2011.

${ }^{23}$ Interview with Sh. M., December 2012.

${ }^{24}$ Interview with Sh. V., May 2011.

${ }^{25}$ Ibid.

${ }^{26}$ Interviews with Sh. V., May 2011, and K. V., August 2011.

${ }^{27}$ Interview with K. G., April 2011.

${ }^{28}$ Interview with Sh. V., May 2011.

${ }^{29}$ Interview with Sh. M., December 2012.

${ }^{30}$ Interviews with K. G., April 2011, and Sh. V., May 2011.

${ }^{31}$ Interview with Sh. V., May 2011.

${ }^{32}$ Interview with K. G., April 2011.

${ }^{33}$ Interview with A. S., November 2011.

${ }^{34}$ Interview with S. V., May 2014.

${ }^{35}$ Interview with Sh. V., May 2011.

36 Ibid.

37 Ibid.

${ }^{38}$ Interview with K. G., April 2011.

${ }^{39}$ Interview with K. G., April 2011.

${ }^{40}$ Interview with A. S., November 2011.

${ }^{41}$ Interviews with K. G., April 2011, Sh. V., May 2011, K. V., August 2011, A. S., November 2011, E. V., December 2012, S. O., December 2013, and S. V., May 2014.

${ }^{42}$ Interviews with K. G., April 2011, Sh. V., May 2011, K. V., August 2011, and A. S., November 2011.

${ }^{43}$ Interview with K. G., April 2011.

${ }^{44}$ Interview with Sh. M., December 2012.

${ }^{45}$ Interview with K. V., August 2011. 
${ }^{46}$ Interviews with K. G., April 2011, Sh. V., May 2011, A. S., November 2011, and S. O., December 2013.

${ }^{47}$ Interview with A. S., November 2011.

48 Ibid.

${ }^{49}$ Interviews with Sh. V., May 2011, and K. V., August 2011.

${ }^{50}$ Interview with Sh. V., May 2011.

${ }^{51}$ Interviews with K. G., April 2011, K. V., August 2011, and A. S., November 2011.

${ }^{52}$ Interviews with Sh. V., May 2011, and A. S., November 2011.

${ }^{53}$ Interview with A. S., November 2011.

${ }^{54}$ Interviews with Sh. V., May 2011, K. V., August 2011, and A. S., November 2011.

\section{REFERENCES}

Assmann 2004 = Assman, Ian. Kul'turnaia pamiat': Pis'mo, pamiat' $i$ politicheskaia identichnost' $v$ vysokikh kul'turakh drevnosti. [Cultural Memory: Writing, Memory and Political Identity in the High Cultures of Antiquity.] Moscow: Iazyki slavianskoi kul'tury.

Assmann 2014 = Assman, Aleida. Dlinnaia ten' proshlogo: Memorial'naia kul'tura $i$ istoricheskaia politika. [The Long Shadow of the Past: Memorial Culture and Historical Policy.] Moscow: Novoe literaturnoe obozrenie.

Basistov \& Ezhova 2005 = Basistov, Iurii \& Ezhova, Galina. Pod znakom krasnoi zvezdy: Gruppa sovetskikh voisk v Germanii. 1945-1994 gg. [Under the Sign of the Red Star: The Group of Soviet Forces in Germany. 1945-1994.] St. Petersburg: Znanie.

Bernau v/ch 47545. [Bernau Military Unit 47545.] Available at http://bernau47545. com.ua/index.php?id=1, last accessed on September 12, 2017.

Boltunov, Mikhail 1995. ZGV: Gor'kaia doroga domoi. [WGT: The Bitter Way Home.] St. Petersburg: Shans. Available at https://www.e-reading.club/book. php?book=1009728, last accessed on September 12, 2017.

Burlakov, Matvei (ed.) 1994. Sovetskie voiska v Germanii 1945-1994: Pamiatnyi al'bom. [The Soviet Troops in Germany 1945-1994: Memorial Album.] Moscow: Molodaia gvardiia.

Büttner, Stefan \& Morré, Jörg 2014. Sowjetische Hinterlassenschaften in Berlin und Brandenburg. Berlin: Ch. Links.

Eimermacher \& Volpert $2010=$ Aimermakher, Karl \& Fol'pert, Astrid. Nemetskosovetskie / rossiiskie otnosheniia vo vremia 'kholodnoi voiny'. [German-Soviet / Russian Relations during the Cold War.] In: Karl Aimermakher \& Gennadii Bordiugov \& Astrid Fol'pert (eds.) Rossiia i Germaniia v XX veke, Tom. 3. Moscow: AIRO-XXI, pp. 9-11. Available at http://www.airo-xxi.ru/-2010-/315--------3---3\#01, last accessed on September 12, 2017. 
Faulenbach 2009 = Faulenbakh, Bernd. GDR mezhdu traditsiei "nemetskogo osobogo puti"' i sovetskim vliianiem. [The GDR Between the Tradition of Special German Path and Soviet Influence.] In: Roman Boldyrev (ed.) Vlast' $i$ obshchestvo $v$ usloviiakh diktatury: Istoricheskii opyt SSSR $i$ GDR 1945-1965. Materialy nauchnoprakticheskoi konferentsii. Arkhangelsk: Pomorskii universitet, pp. 90-99.

Feskov \& Kalashnikov \& Golikov 2004 = Fes'kov, Vitalii \& Kalashnikov, Konstantin \& Golikov, Valerii. Sovetskaia Armiia v gody 'kholodnoi voiny' (1945-1991). [The Soviet Army during the Cold War (1945-1991).] Tomsk: Tomskii universitet.

Gehrke, Thilo 2008. Das Erbe der Sowjetarmee in Deutschland: Eine Bild- und Texdokumentation. Berlin: Dr. Köster.

Gruppa Sovetskikh Voisk v Germanii. [The Group of Soviet Forces in Germany.] Available at http://www.gsvg.ru/vospomonania_veteranov/, last accessed on September 12, 2017.

Habermas 2015 [2011] = Khabermas, Iurgen. Ot kartin mira $k$ zhiznennomu miru. [From Pictures of the World to the Life World.] Moscow: Ideia-Press.

Hoffmann, Hans-Albert \& Stoof, Siegfried 2008. Sowjetische Truppen in Deutschland und ihr Hauptquartier in Wünsdorf 1945-1994: Geschichte, Fakten, Hintergründe. Berlin: Dr. Köster.

Khurbaev, Rustam 1981. Armiia - shkola moia. [Army - My School.] Moscow: DOSAAF.

Kowalczuk, Ilko-Sascha \& Wolle, Stefan 2001. Roter Stern über Deutschland: Sowjetische Truppen in der DDR. Berlin: Ch. Links.

Liubit' rodinu 1960 = Liubit' rodinu i nenavidet' ee vragov - patrioticheskii dolg sovetskikh voinov. [To Love the Motherland and to Hate Its Enemies - the Patriotic Duty of Soviet Soldiers.] Collection of articles. N.p.: Politicheskoe upravlenie GSVG.

Lohmann, Horst 2010. GSSD - Die Gruppe der Sowjetischen Streitkräfte in Deutschland 1945-1994: Ein historischer Abriss. Hoppegarten: E. Meißler.

Luchkin, Aleksei 2014. Davshie obeschanie ne davat'obeshchanii. [They Have Promised Not to Make Promises.] Shadrinsk: Shadrinskii Dom pechati.

Na boevom postu $1975=$ Na boevom postu: Kniga o voinah Gruppy sovetskikh voisk $v$ Germanii 1975. [On the Fighting Post: The Book about the Battles of the Group of the Soviet Forces in Germany.] Compiled by P. M. Rakitin \& V. B. Sias'ko. Moscow: Voenizdat.

Satjukow, Silke 2003. Sowjetische Streitkräfte und DDR-Bevölkerung: Tour d'horizon einer Beziehung. Deutschland Archiv, No. 3, pp. 414-428.

Satjukow, Silke 2008. Besatzer: 'Die Russen' in Deutschland 1945-1994. [Occupiers: The Russians in Germany 1945-1994.] Göttingen: Vandenhoeck \& Ruprecht.

Sladkova, Alena 2015. Problema sotsial'noi legitimatsii v zapadnoi filosofii vtoroi poloviny $X X$ - nachala XXI veka. [The Problem of Social Legitimation in the Western Philosophy of the Second Half of the 20th - Beginning of the 21st Century.] Dis. kand. filosof. nauk. Tverskoi Gosudarstvennyi Universitet. Available at http://avtoref.mgou.ru/new/d212.155.08/Sladkova/diss.pdf, last accessed on September 13, 2017.

Tikhomirova, Anna 2008. Ot Shraibikusa do 'indeitsev i kovboitsev': GDR v zhiznennom mire sovetskogo rebenka 1980-kh godov. [From Shraibikus to 'Indians and Cowboys': The GDR in Life World of the Soviet Child in the 1980s.] Neprikosnovennyi zapas, No. 2 (58), pp. 243-258. Available at http://magazines.russ.ru/nz/2008/2/ti21. html, last accessed on September 13, 2017. 
Tolmachev, Evgenii 2010. Nebesnyi strazh GSVG. [Heavenly Guardian of the GSFG.] Kaluga: Manuscript.

Varennikov, Valentin 2001. Nepovtorimoe. [Unrepeatable Past.] Vol. 3. Moscow: Sovetskii pisatel'.

Vatlin, Aleksandr 2009. Formirovanie obraza 'novoi Germanii' v sovetskoi propagande nachala 50-kh godov. [Formation of the Image of the 'New Germany' in the Soviet Propaganda of the Early 1950s.] In: Roman Boldyrev (ed.) Vlast' i obshchestvo v usloviiakh diktatury: Istoricheskii opyt SSSR i GDR 1945-1965. Materialy nauchnoprakticheskoi konferentsii. Arkhangelsk: Pomorskii universitet, pp.172-187.

Vershinin, Sergei 2003. Obraz GDR v sovetskom massovom soznanii: k postanovke problemy. [The Image of the GDR in the Soviet Mass Consciousness: To the Formulation of the Problem.] Nauchnyi ezhegodnik Instituta filosofii $i$ prava UrORAN, Vol. 4, pp. 336-353.

Zdravomyslov, Andrei 2003. Nemtsy o russkikh na poroge novogo tysiacheletiia: besedy $v$ Germanii. [Germans and Russians at the Threshold of the New Millennium: Conversations in Germany.] Moscow: ROSSPEN.

Zemskov, Igor N. (ed.) 1981. SSSR - GDR. 30 let otnoshenii, 1949-1979: Dokumenty $i$ materialy. [The USSR - the GDR. 30 Years of the Relations, 1949-1979: Documents and Materials.] Moscow: Politizdat.

Zhdanov, Nikolai 1975. Tsennoe posobie. [Valuable Guide.] Voennyi vestnik, No. 6, p. 126. XXIV s"ezd KPSS 1971 = XXIV s"ezd KPSS: Al'bom nagliadnykh posobii. [24th Congress of the CPSU: Album with Posters.] Wünsdorf: Politupravlenie GSVG. 


\title{
"INVISIBLE PLACES, HIDDEN HISTORY": THE ROLE OF THE FORMER "RUSSIAN AIRPORT" IN TELLING STORIES ABOUT THE FRONT IN THE SOUTH VÉRTES REGION
}

\author{
István Sántha \\ Research Centre for the Humanities \\ Hungarian Academy of Sciences, Hungary \\ e-mail: istvansantha@gmail.com
}

\begin{abstract}
The South Vértes is one of the regions in Hungary where the battles between the opposing Hungarian-German and Russian sides went on for the longest period of time and were the severest. The fates of the people living in the region varied, as every village had its unique history and played a different role in the war. Moreover, individual families expressed unique attitudes in their narratives about the front, depending on whether they survived the war without major losses or suffered great traumas. The article explores stories told by local people about the "Russian airport", the only Soviet barracks established in the region after World War II, and how it was linked to the violent events of the war. While the Russian barracks in general appeared to serve as a platform for the fear accompanying the comments on World War II, different generations of local people have different positions in relation to the front and rely on different techniques for telling stories about the war. The focus is on people who were born during or just before the war and consequently have limited personal experience of the front. Members of this generation unconsciously use the "Russian airport" and its residents as a parallel platform to talk about World War II and experiences involving their families, exemplifying the complexities of communicating about the war and emotions.
\end{abstract}

Keywords: emotions, Hungary, military airport, paradox, social anthropology, Soviet block, South Vértes region, storytelling, trauma, World War II

The South Vértes is one of the regions in Hungary where the battles between the opposing Hungarian-German and Russian sides went on for the longest period of time and were the severest. Although some of the Russian troops reached German territories in the middle of March, 1945, at that time there were still military operations in the South Vértes region. The front divided the region for three months but some months before that spying and sporadic military operations were going on in the South Vértes. However, the fate of various 
people living in this multiethnic region was not always the same, as every village had its unique history and played a different role in the war. Some villages were seized by one side or the other for months, while others changed hands five or even more times. Even people from the same village often had different experiences, depending on whether they were living at one or the other end of the village. While fieldwork conducted at the end of 2015 and the beginning of 2016 took us ${ }^{1}$ to several Hungarian and two Swabian villages, and we also encountered individual Jewish families everywhere in the South Vértes, little is known about whether this multiethnic picture of the region had any influence on the actions of Soviet soldiers ${ }^{2}$ against the inhabitants of these villages. When telling stories about the front, individual families expressed different views depending on whether they survived the war without major losses or suffered great traumas.

The aim of this article is to investigate the role of the former "Russian airport" in the life of the region and local people. ${ }^{3}$ The "Russian airport", to use the local term, was a military complex comprised of three objects: an airfield built during World War II, the Russian barracks, consisting of various buildings, and the "radar station", which was used for officers' and pilots' recreation and included sleeping quarters, a Russian sauna, and a landing area for helicopters. The significance of this research topic is emphasized by the fact that the "Russian airport" was the only Russian barracks in this war-stricken region. This will be of importance when examining the relations between the violent events of the war and the Russian barracks. While this connection may seem trivial, it deserves attention because it was introduced not by researchers, but by the local people who unconsciously pushed the conversation in this direction. Although the primary function of the barracks was to be invisible (and inaccessible), my fieldwork indicates that it existed in the lives and minds of local people and it has been part of the local cognitive map. Every day, when people took the road to the county seat, they passed by the barracks and saw signs of the Russian presence. This led to some people recalling World War II memories that they immediately had to suppress. In this way, the Russian barracks became a platform for the fear accompanying comments on World War II. ${ }^{4}$

Members of the older generation with first-hand experience of the front did not need a landmark that would make it easier for them to express their emotions: if they were willing to talk about events on the front, they could directly recall their own experiences and memories. In their case we could at most say that talking about the collective traumas caused by events on the front provided a way for them to talk about deeper individual traumas. Individuals born during or just before the war had fewer personal experiences and unconsciously used the Russian barracks (and their residents) as a platform to talk about World 
War II events and experiences involving their families. Members of this generation talked about the Russian barracks and the war events with the same intensity. To be able to find a framework for understanding these fundamental motivations, we need to know the unwritten history of these villages, the history that is only passed down orally. Members of the generation born between 1946 and 1956, who came into contact with the Russian barracks because of trade or for some other practical reason, were able to talk to younger generations and outsiders about the facts but not the emotions connected to the war experiences of their families.

\section{SOUTH VÉRTES CONTEXTS}

In the following section, I would like to briefly describe the history of the "Russian airport" and discuss some of the problems related to it. It must be pointed out that the significance of the presence of Russian troops in the region after World War II is difficult to explain, as it only became more discernible towards the time of their departure, in 1991. The beginning of the history of the "Russian airport" is rather obscure. Everyone (including József K., one of the local builders of the Russian barracks) has his or her own personal story and experience of when they met the Russian soldiers for the first time after World War II.

Significantly, the area had military functions even before the "Russian airport" was established, as it was used for military training between World War I and World War II. In terms of infrastructure, the area was then favorably located. Both the nearby bauxite mine and the narrow-gauge railway used for transporting the bauxite became strategically important in the course of the war. Moreover, during the war, the Hungarian state established a Polish camp near the later site of the "Russian airport" for Polish soldiers who had escaped from Poland after the beginning of the German occupation. To this day, maps refer to this valley as the "Polish camp" (Lengyel tábor). The airfield was established during World War II and became the reserve airport for the Budapest airports of Mátyásföld and Budaörs. Among others, the family of the Earl of South Vértes and the daughter-in-law of the governor of Hungary, Miklós Horthy, escaped through this airport and negotiators taking part in secret negotiations with the Soviet Union also left through it in August, 1944 (Romsics 2003 [1999]). After World War II the airport was out of operation for a while and only Hungarian signalers appeared there from time to time. Hungarian troops were said to have served at the airport until 1954. Thus, we should note that after World War II there was no permanent Russian military presence in the region until right before the Hungarian Revolution of 1956. 
This 1956 uprising, similarly to the 1968 events in Czechoslovakia, provided the Soviets with an excuse to reinstate and stabilize their military presence in Hungary. Occasional earlier post-war Russian appearances in the South Vértes region can be considered premonitory signs of the events of 1956. Similar trends occurred in 1968 and together they help us interpret changes triggered by these two historical events. Furthermore, before 1956, the reserve nature of the airport meant that it was in temporary use and occupied sporadically. After 1956, processes accelerated, and with the events of 1968 the need for a permanent presence was clear. From the point of view of the communist leaders, the events of 1956 and 1968 explained the usefulness and necessity of the Russian military presence in the region. Before 1968, the Russian barracks consisted of only one building, with soldiers living in tents. The other buildings, mostly still in existence today, were erected between 1966 and 1968 by the South Vértes ktsz, a small industrial co-operative. The radar station on the hill was established in 1968 and served mostly recreational purposes. Another sign of development and stabilization was that the runway was paved and a helicopter landing and parking area was also established. The "reserve" status of the airport, a continuation of the situation in World War II, was changed to a "combat" status during times of armed conflict. In 1956 nothing much was happening in the region. This apparent peace enabled forces in the area to leave for other regions, "hot spots" (as in 1968, when the airport was one of the military pooling bases in Hungary for transit to Czechoslovakia).

We can only briefly summarize the events of 1956 in the region, which is sufficient because others, such as Péter Antal Polgár (2007), have published thorough studies on this subject. Given the foci and anthropological methodology of the present paper, it is important to note that the prevailing mood in the region was characterized by moderation, opening up and establishing ties with the outside world and breaking out of isolation. There were two armed incidents in the region. Interestingly, in one of the Swabian villages it was foreign miners who generated revolutionary action (ibid.). In the other Swabian village, there was an armed conflict between people fleeing from Budapest and Russian forces who were helped by the Hungarian secret police force (ibid.; also my own research).

The peculiar nature of the region can be seen in connection with the events of 1956. In critical historical moments, a contiguous mountain range with its forests provided hiding places for those fleeing from persecutors. For example, people from Csákvár, once a residence of local earls and now a small city of regional significance, who took an active role in the militia in Székesfehérvár, the county seat, hid for months in the nearby vineyards (my own research). Beyond these historical events of local importance, villages of the region took 
part in supplying food to revolutionaries in Budapest. Any kind of long-lasting activity (such as involvement in the militia or in revolutionary committees) occurred only in the centers, i.e. in county seats. A scenario more typical for the villages of the area was to take advantage of the temporary situation by destroying Russian military memorials ${ }^{5}$ or, mostly in Swabian villages, to emigrate. Generally, the mood in the bauxite mines located in the region was moderate (Nagy 2002). The desire for revenge, which there was no trace of in recollections or documents, was suppressed and stayed underground. Two more comments should be made in connection with the situation. The first is that the effects of (criminal) atrocities and political motivations were elusive in the feelings of the local people. The other is that retaliations after World War II and 1956 were mixed in memory: people were not able or not willing to separate them in their recollections. ${ }^{6}$

\section{SOURCES AND THEORETICAL BACKGROUND}

An important feature of the present research is the complete lack of written sources. I could find neither Hungarian nor Russian archival (printed or handwritten) materials about the South Vértes barracks. This is not surprising, as the Russian barracks were secret military objects. Although there were no archival traces of the South Vértes barracks, some surprising material about the region can be found on some Russian websites (e.g. Obobshchennyi bank dannykh "Memorial"). ${ }^{7}$ This includes the most complete list of Russian soldiers who died in World War II, including the locations where they perished, their names, places and dates of birth, a list of Russian war memorials with photographs and information on how they were renovated, and the correspondence of former Russian soldiers who later, as tourists, returned to their former barracks to photograph and document any changes in the buildings and to refresh their memories of the distant past.

The lack of usable maps is a general problem, and this is also a consequence of the military nature of the region. The secrecy of a military training center or an airport is of utmost importance. Especially in times of war or military conflict, such as a revolution, counter-revolution, civil war or even the possibility of these actions, secret information becomes precious, even though in times of peace this secrecy might seem superfluous to members of the civilian population. ${ }^{8}$ That being said, it is obvious that the present research can only deal with collecting folklore and storytelling. The plan was to find local elders, witnesses and other people who took part in the events, and to persuade them to talk about their encounters with Russians. 


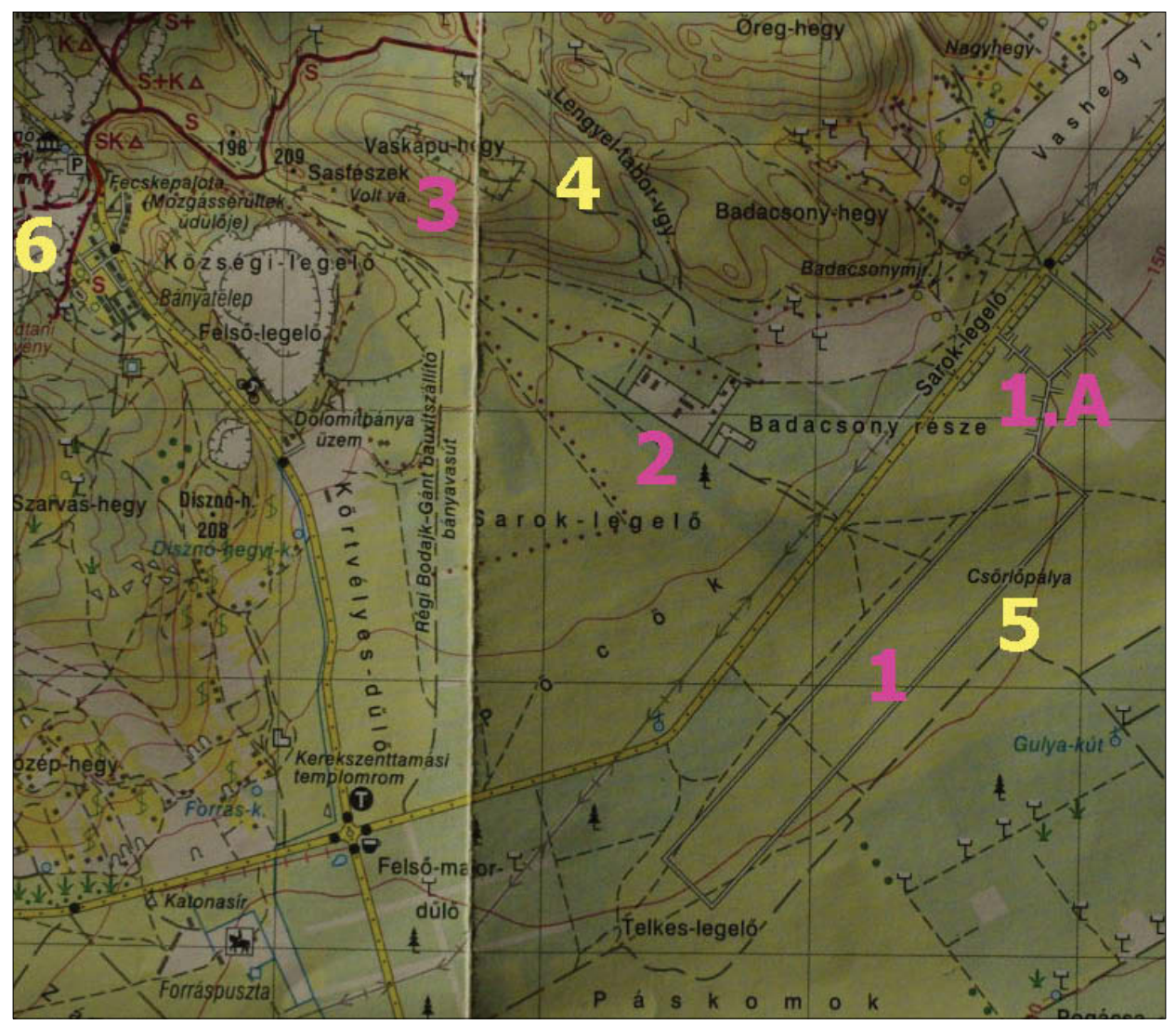

Figure 1. Map of the neighborhood of the former Russian military complex: 1 - airfield; 1 .A - helipad; 2 - Russian barrack; 3 - radar station; 4 - Polish camp; 5 - winch track; 6 - bauxite mine. Photograph by István Sántha, January 2017.

The object of this study, a former "Russian airport" that serves the local people as a symbolic space for working through their emotions, raises the significance of Marc Augé's notion of "non-places" (1995; 2002) (Fig. 2). The concept of non-places originates from Pierre Nora's idea of "places of memory" and in a more general sense from contemporary French philosophy and urban studies, reinterpreted by Augé by means of anthropological frameworks. Augé's philosophy of anthropology is in opposition to conventional history as well as to social science and anthropology. His concept is based on the crisis of meaning. According to his interpretation, there are places (he calls them "non-places") concerning which it is meaningless to attempt to build identity, create history, decode symbols or interpret relationships. Examples of non-places for Augé are the Paris subway, airports, and other modern places. 
The Role of the Former "Russian Airport" in Telling Stories about the Front

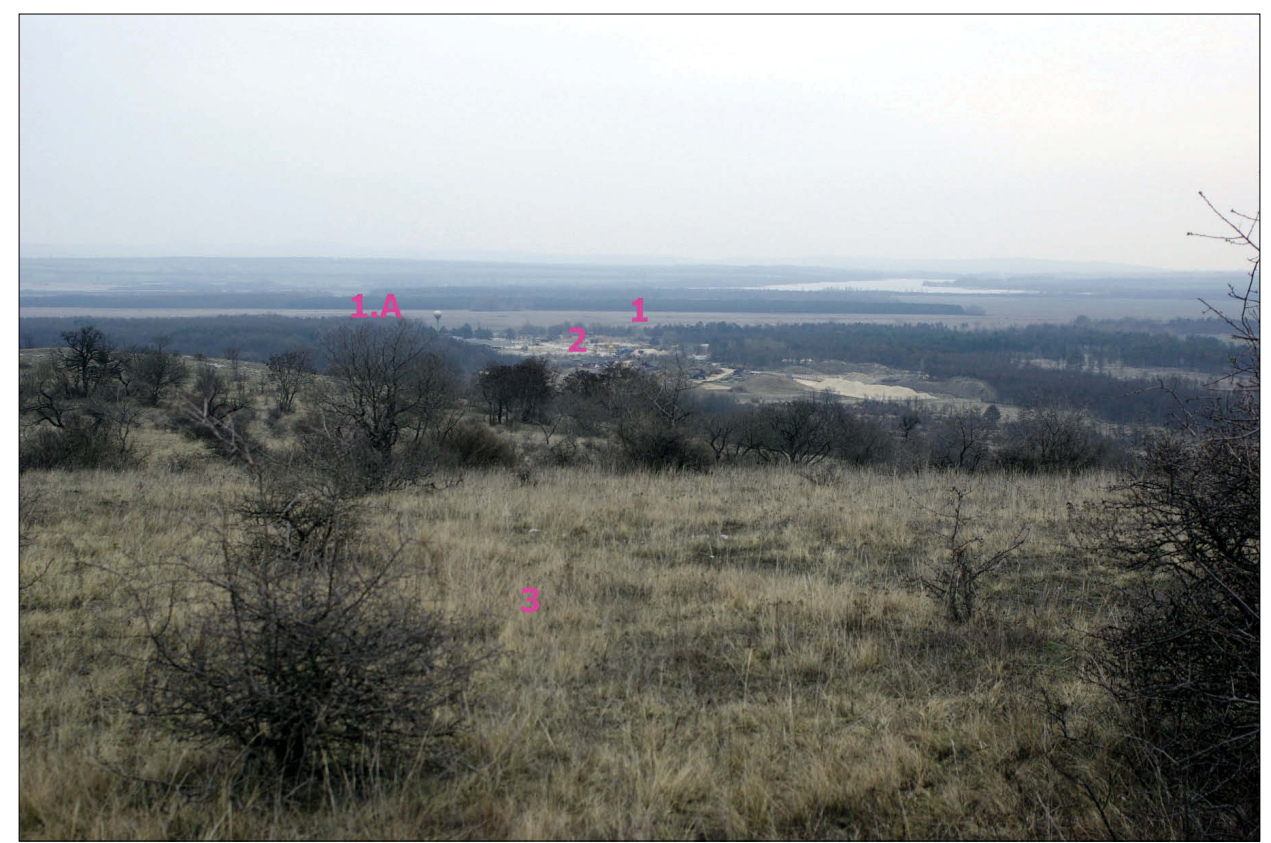

Figure 2. Landscape of the former Russian military complex: 1 - airfield; 1.A - helipad; 2 - Russian barrack; 3 - radar station. Photograph by István Sántha, March 2016.

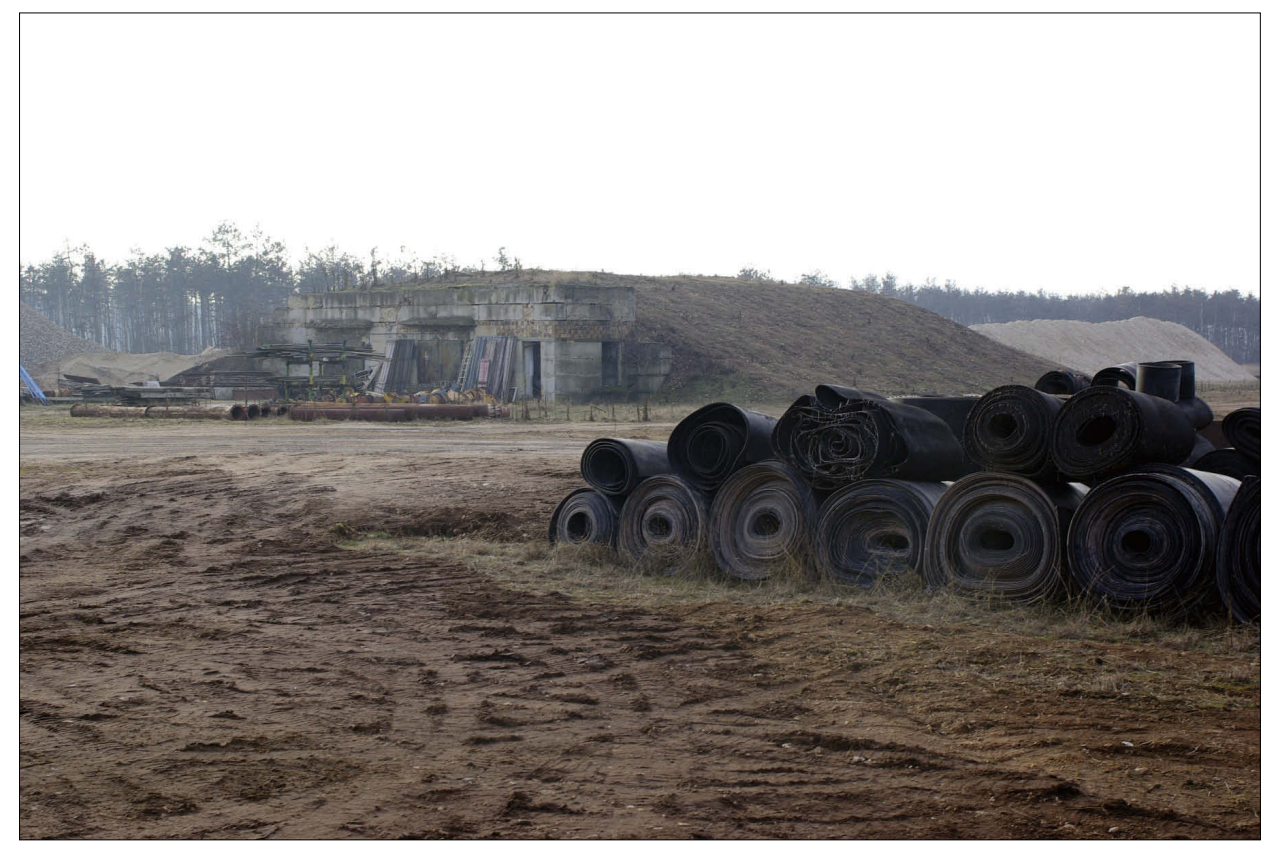

Figure 3. Bunker in the territory of the Russian barrack. Photograph by Istuán Sántha, November 2015. 
It should be noted that the lack of points of reference is significant because the object of this study is a secret military area. The question is how to construct history if there are no points of reference for storytelling. Yet, in the course of this research it was possible to find points of reference that might help us to apply historical infrastructural considerations. In this way we have the opportunity to create a "little history", a microhistory, of a particular place in a particular historical moment, without aiming to relate to the "big history". And yet, the question arises as to whether that makes sense at all, if due to the nature of the object (military, hidden, with an occupational function), invisibility and being outside of history were significant aspects of the Soviet military object. The airport was also invisible because it belonged to the military reserve; it did not belong to any of the larger barracks of the neighboring regions, but was directly subordinated to the Soviet Air Command, and this also meant that only a few soldiers served there (three officers and from ten to fifteen private soldiers). Of course, in practice things were somewhat different. Primarily hidden objectives were also revealed in 1956 and 1968, when the airport was changed from reserve to combat status, and, as a result, became more visible.

\section{LIZI'S STORIES}

The owner of the pub in the village nearest to the Russian barrack in the South Vértes region, the elderly Lizi (born in 1942), was sitting at the table across from the entrance when my friend and I, finding shelter from a heavy rain, entered the pub. The previous day, as I was doing research for a study exploring the history of a bauxite mine (Nagy 2002), I came across the unusual name of a friend from high school. When I called my friend's attention to this, he asked me if I could help him unravel the story of his grandfather, who had worked as a mining engineer in that mine before World War II. I thought that the best way to gain information about my friend's grandfather would be to see an elderly man who still lived near the site of the mine. When we tried to see him at his place, we learned that on Sundays he went to the village cemetery close to the mining site to visit the graves of his relatives. We went to look for him at the cemetery but found neither him nor his car. We decided to stay around, hoping he would turn up after the rain had stopped and that is how we ended up at the village pub.

My parents were acquainted with Lizi's mother. I first met Lizi personally in January 2016. Since then I have seen her from time to time when I visit the village. As we were inquiring about my friend's grandfather, she mentioned that she had personally known my friend's father, but she knew nothing about 
his grandfather. Seeing that the conversation would not provide any further information, and taking advantage of the opportunity, I asked Lizi and my friend if maybe we could talk about something else. I told Lizi that I had been doing research on World War II, and that I had visited the village recently. I even told her that, although more than half of the men living in the settlement belonging to the village were killed by the Russians (eleven adult males out of a total population of fifty-two), based on my experience so far, I had come to the conclusion that, compared to the surrounding villages, the village had survived the hardship of the war without major difficulties.

Lizi, however, saw it differently. She told us how Russians had taken away her aunt by force and kept her in a cellar for three days. After the war her aunt emigrated to the United States, but even as an old woman she was unable to get over the terrible things that had happened to her during the war. Lizi was very upset and her voice was shaking with anger while she was telling the story of her aunt.

Then, all of a sudden, Lizi started to tell stories about the Russian soldiers stationed in the region after World War II. There was the same anger in her voice when she spoke about the "ugly" ways the Russian officers treated the private soldiers. As an illustration, she told me two stories, both of which were in connection with her mother, Mári.

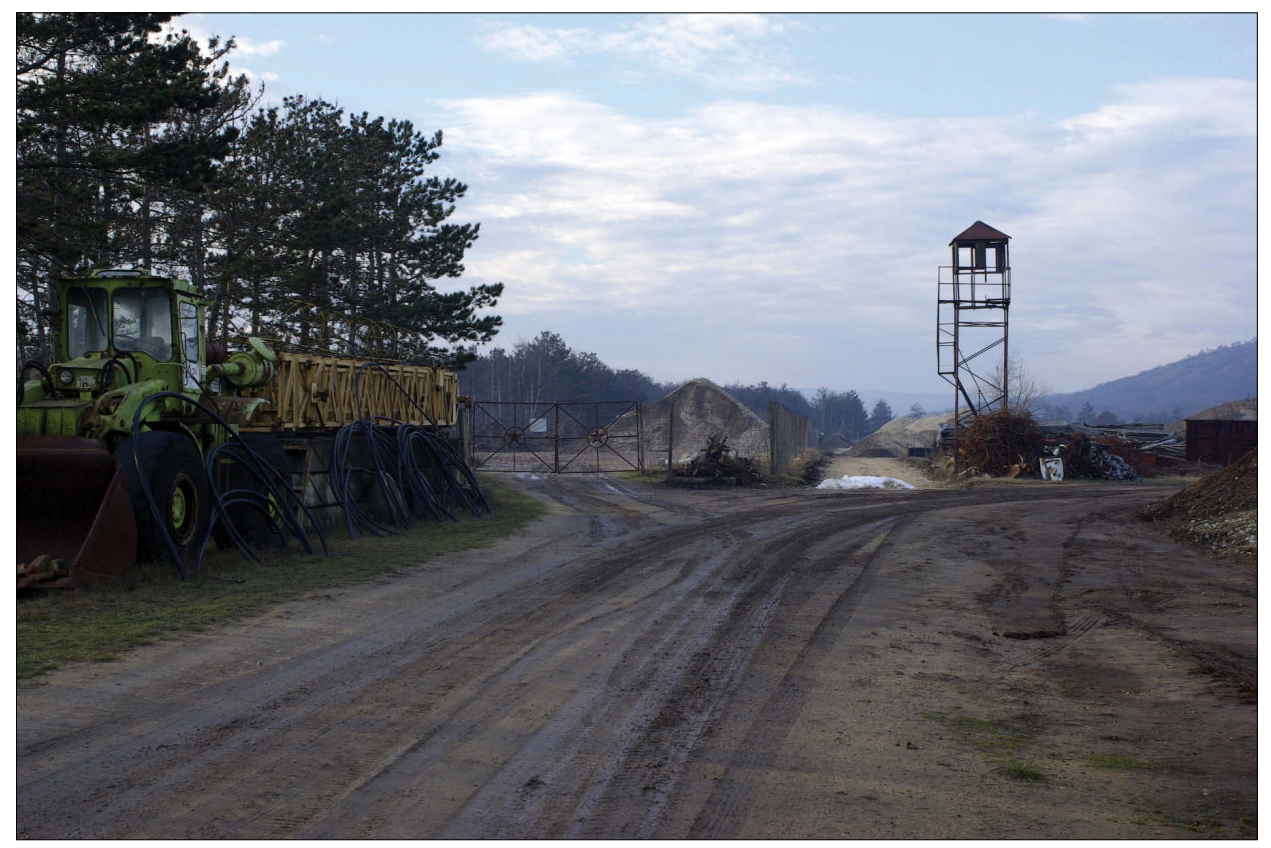

Figure 4. Russian barrack. Photograph by István Sántha, November 2015. 
In the first story, Mári felt sorry for a few soldiers standing outside in freezing temperatures and wanted to give them pastries. When the officers drinking in the warm village pub saw this, they did not like it. One of the officers, noticing that Mári was trying to outfox them, took the plate with the pastries, threw it on the ground and even stomped on it. "They are not human beings," said Lizi, reflecting her feelings about the atrocities committed against her whole family.

The second story is about a Russian soldier who once took a bedsheet to the village pub in order to exchange it for cigarettes. Seeing that the bedsheet was used and that it was probably the soldier's only one, Mári took pity on the soldier lad and gave him cigarettes without accepting anything in return. At this point, in the street she saw a Russian officer who was obviously chasing the soldier. Overcoming her fear, Mári hid the soldier in one of the rooms of the pub. The officer noticed the soldier's feet sticking out under a curtain. While Mári distracted the officer, the soldier escaped through the pub's back window and ran through the adjacent forest, straight to the barrack. The officer got into a UAZ (Russian military jeep) and taking the paved road around the forest, drove to the barrack. Mári could only hope that the soldier arrived there first. This event made Mári very upset.

After some time, a Russian officer came looking for Mári in the pub. Lizi insisted that her mother was ill and confined to bed. Realizing that the officer would not give up on the matter, they got very frightened. With the help of a translator, another Russian soldier, they learned that the officer had been re-assigned and so he had come to say goodbye and express his respect for Mári's bravery in helping the soldier escape.

Figure 5. Watchtower in the territory of the Russian barrack. Photograph by István Sántha, November 2015.

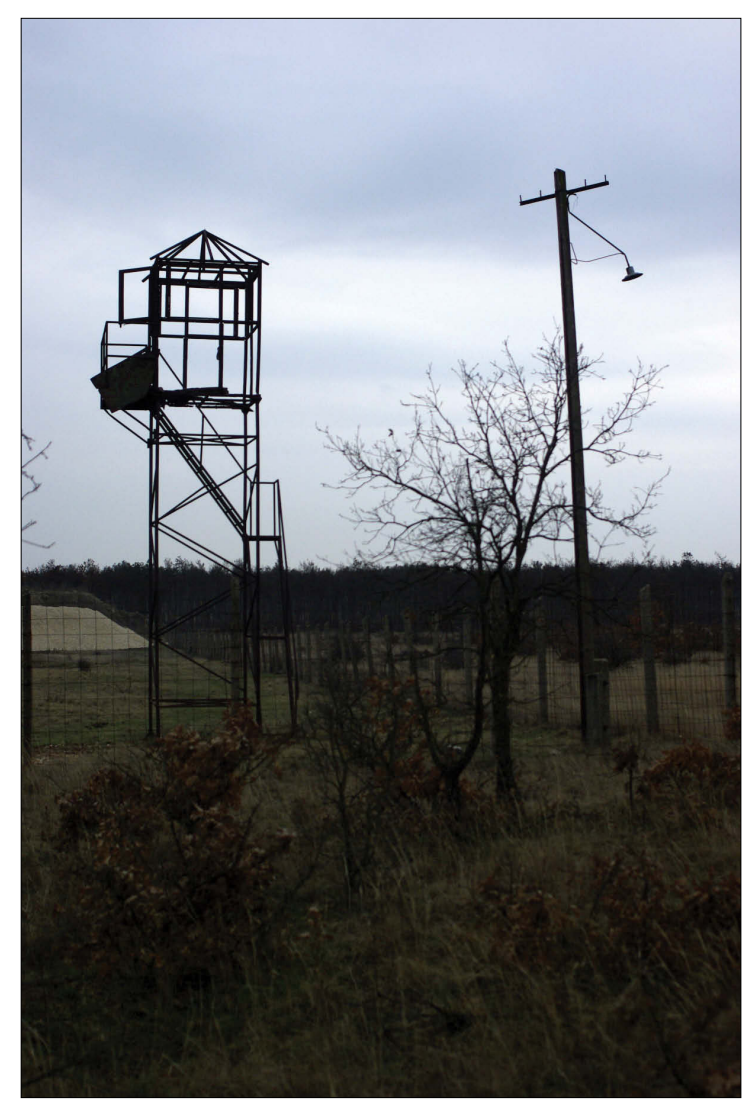




\section{STORYTELLING TECHNIQUE}

One of the main methodological approaches applied in the present research concerns storytelling. As Tatiana Safonova and I have already pointed out in our earlier research on Siberia (Safonova \& Sántha 2013), explaining communication is a complex task that requires a flexible approach. In order to interpret communication processes, we have to uncover those meta-messages that are involved in the communication process. In order to understand each other, we have to transmit not only content but also messages about how to interpret content: the meta-message is the information needed to interpret the framework. ${ }^{9}$ Passing on information about culture can happen not only through the transmitting of knowledge from one generation to another (i.e. in the form of storytelling) but also through developing the capability of telling stories. Only the successful transmission of these capabilities can ensure understanding (Sacks 1992). Telling and interpreting stories are two-way processes, based on how stories are experienced (Sántha \& Safonova 2011: 124).

Furthermore, it is worth considering what we experienced during our field trip to Siberia, namely that remembering and storytelling are complex processes that not everyone is capable of mastering. The shaman formulates what he sees through his own cultural concepts or through signs sent to him by his ancestors. The shaman's own experiences and his commentary are also part of the ritual (emotional involvement). The shamanic ritual is a practice that controls the process of remembering. The shaman is a specialist who can restore and interpret lost memories. From the shaman's perspective, storytelling is a shamanic ritual that serves practical considerations; it is the endless retelling of his own biography based on legends about the ancestors. The tragedies and dramas preserved in legends are supported by his own experiences of risky situations. During rituals, as a shaman he behaves according to the traits of his ancestors. It is the capacity of every shaman to present a personal biography through risky situations. Risky situations (traumas) need to be experienced and have to be talked about in order for them to intertwine through shamanic practices as, according to the Siberian Buryats, to talk about something does not entail less risk than to experience it in practice (Sántha \& Safonova 2011: 152-153).

Narratives about ancestors mainly revolve around risky situations, dramas, and tragedies (traumas). Incorporating a personal risk experience into knowledge about ancestors, narratives and storytelling boost an individual's reputation in the community. This emphasizes the importance of remembering as the essence of Buryat culture (Humphrey 1979). For Buryats, to remember means to integrate one's own experience into the legendary history. Historical knowledge about ancestors creates a filing system or catalog for people in the 
present to make sense of their experiences and stories. Thus, the greater the individual knowledge of ancestral history, the richer the repertoire of personal memories. Furthermore, only those with such knowledge can inherit the nature (characteristics) of ancestors and can relate an autobiography. The shaman interprets stories through the spirit helper of his family (one of the ancestors). He can remember and retell the whole story only because the situation has been resolved through the assistance of ancestors (this is a sign that the situation was dangerous). As the shaman possesses the most extensive filing system of knowledge about ancestors, he bears the richest autobiography in his local community. His "memories" are the basis upon which rituals are conducted for those who do not possess the needed knowledge and skill to construct their own biographies and to reflect on their personal experiences (Safonova \& Sántha 2010: 10).

When Lizi was interpreting family stories, this reminded me of the way Buryat shamans evoke stories about their ancestors. The fact that the stories in both cases are related to tragic events emphasizes the significance of the emotional aspect of storytelling. The knowledge of stories is not based on personal experiences, and the storytellers are emotionally involved in situations connected with relatives; these are common features in both cases. The emotional involvement in a story about which the teller does not have personal recollections (the teller was too young to remember) creates a special perspective to tell the story and analyze the teller's own biography through stories of others. These story appropriations and a form of knowledge transmission look similar in cases of shamanic narratives from the west side of Lake Baikal and recollections of war stories of inhabitants of South Vértes.

\section{THE STORY OF ANNUSKA}

Earlier, I did research on the large number of cases of sexual violence committed against minors during the war in the South Vértes region (Sántha 2016). In doing research on this topic, I was also motivated by the fact that there were fewer and fewer victims and witnesses of these incidents who were also willing to talk about their experiences and observations. While doing this research, I came to the conclusion that the front was the most serious trauma a person could experience in his or her life. However, I was wrong. The story of an old lady, Annuska (born in 1920), called my attention to the fact that talking about a certain trauma can open the door to talking about other traumatic events.

It was one of the family members who called my attention to the fact that the ninety-six-year-old Annuska was a victim, and they suggested that I should 
ask her about what she did and what happened to her during the period the frontline remained in the region. During our conversation, I could picture her as a young woman left alone by her husband who was away defending his homeland. She moved with her one-year-old son from settlement to settlement, fleeing from the Russian army. Annuska gave a detailed account of her horror when the Russians unexpectedly appeared in one of those places. And yet, she kept trying to find opportunities to change the subject and the context of the conversation to be able to talk about the fate of her son, how he was murdered at the age of forty. ${ }^{10}$ At first I tried to determine the connection, this shifting of the topic, but later I was impressed by the shifting itself as a storytelling technique. During our several encounters, Annuska used this technique several times to shift between the same topics. I thought then that the story of the rape, being a public one in the sense that it was a trauma shared by the greater public, opened up a path for talking about a very private personal trauma. Then I also started to pay attention to the use of the same shifting technique in the stories of others, but Annuska gave me the first lesson on shifting. As a next step, it seemed that it was not only possible to have connections between different traumas but a trauma could also be sustained through other topics not connected to any traumas. On second thought, we cannot ignore, as in the case of Lizi that, although for the outside listener the second traumatic event might not have appeared to be traumatic at all, it carried trauma for the victim; Mári fearfully hid from the Russian officer when he wanted to meet her in person.

\section{FRAMEWORKS FOR INTERPRETING LIZI'S STORIES}

Returning to the two stories told by Lizi, it should be noted that their content suggests that all kinds of contacts between the occupying Russian soldiers and the occupied Hungarian civilian population were forbidden. Still, in practice, the example of the Russian barrack indicates a hierarchically organized Russian society in which officers tried by all means to control the development of relations between the soldiers and the local civilians. We can apply this as an approach when interpreting the behavior of the Russian soldiers during the period the frontline remained in the region. For example, in the life of cellar communities $^{11}$ the presence of a Russian officer provided protection against the violence of soldiers.

This did not automatically mean that it was only the officers who could have had contact with civilians, even though the practices of the occupiers after World War II indicate this. The idea behind this way of organizing society could have been to reduce spying and to prevent people from obtaining any 
information about the operation of the Red Army. As I indicated in my previous study (Sántha 2016), this was the reason why between the Russian soldiers and the female population of the occupied territories any kind of relationship based on emotions, such as love or marriage, was prohibited, both for officers and soldiers (Mészáros 2014). ${ }^{12}$

The action in Lizi's two stories involving officers and soldiers serving in the nearby Russian barrack happened in the 1970s and 1980s. In connection with the soldier who escaped through the forest, we should note that Lizi knew the region around the airport because before World War I, like many other Swabian families in the village, her family had purchased land near the airport because of the scarcity of available land near the village. After the war, the land was confiscated from the family and to this day their descendants have not gotten it back.

In connection with the events that happened in the village during the period the frontline remained there, I would like to briefly note that the Swabian village nestled in the South Vértes suffered less during the war than other villages of the region. We could also add that naturally this varied from family to family, even if atrocities were committed only against one family member. As we saw in the case of Lizi, present-day descendants of some families experience and interpret these generalities differently. When I was introducing the subject of World War II and expressed my preconception that the Swabian village in the South Vértes did not suffer so severely during the war, to my surprise Lizi disagreed with this statement.

It turned out that through one family member Lizi was personally involved in suffering. While she was telling her story, Lizi automatically switched to talking about her own experiences in connection with the Russians. Her mother was the connection between the two situations she referred to. To be more precise, two members of a previous generation had had similar experiences with Russians. One was a victim and the other was a witness of the events. Lizi was too young to understand (or to remember) what was happening around her, what was happening to her relatives and neighbors. She only received impressions of the intensity of emotions. Intensity and passion created the continuity between different generations, between victims and witnesses.

The intensity of the storytelling, and the values and opinions of the storytellers were the same for family members of different generations. The decision of the aunt (who was a victim) to emigrate to Germany with the other deported Swabians ${ }^{13}$ was made partly because she believed she would be able to leave behind the things that had happened to her. Unfortunately, it did not turn out that way. Soon she decided to leave this émigré "community of witnesses" in Germany and moved on to the USA, where as an old woman she could not come 
to grips with her former experiences and broke down. In her absence, the former witness, the niece Mári (in other words, Lizi's mother) was the victim in the local community. With her values and morals, she was the one who created the connection between events of the present and the past. The present storyteller (the witness of the events of the recent past) commemorates the witnessing of terrible events and maintains the family tradition.

Lizi achieved continuity with the intensity of her opinion, which reflects the level of the terrible things committed against one of her family members. Through her storytelling, she sought continuity in the events of the family history and at the same time established a connection between two apparently different contexts. The case of Lizi made me consider the general presence of similar shifts as part of the storytelling technique. Below, I would like to discuss two more cases. In both cases, the storyteller, like Lizi, was a member of the generation born during the war but, lacking personal experiences and observations, they could authentically transmit only the experiences of other, older family members.

\section{THE CASE OF JÓZSEF K.}

I visited József K. (born in 1939) because, according to his former mason colleagues, as a technical inspector he participated in the construction of some of the buildings of the Russian barrack. As an introduction, I asked him to tell me about his first encounter with Russians. I thought that he would talk about his impressions when, as part of his job, he had first visited the Russian barrack. Quite unexpectedly, he started to talk about the war. He saw that I was surprised by this unexpected turn of our conversation. Slowly, with the help of his wife, he gathered his memories. It was difficult for him to separate his own experiences from those of other, older family members. He described how cruel members of the Ukrainian outpost were and how they did not respect anyone. He also mentioned that he remembered well the Russian soldiers (who followed the exhausted Ukrainians) relaxing in the soft grass of the embankment. Older Russian soldiers belonged to the Orthodox faith and they willingly participated in family Christmas events. Finally, he told me about an officer of Kirghiz origin who was quartered in his house and was extremely cruel to his servant, even whipping him.

I also found it strange that while I preferred the more colloquial term "Russians", József K. talked about the "Soviets". In his stories he mentioned Soviet soldiers and Soviet people. Presumably, this was important to him because in this way he could refer to Red Army soldiers of different ethnicities (Russian, 
Kirghiz, Cossack, and Ukrainian) passing through the village. It was only later that he started to talk about his actions and personal experiences at the, as he called it, Soviet barrack, which in common usage was referred to as the Russian barrack.

In his stories, József K. talked calmly and distinctly about the Soviet people, both with regard to the front and the barrack. An outsider who did not know anything about the family history would think that József $\mathrm{K}$. was unable to express his emotions and passions, and yet it was only because the family survived the war without any traumatic episodes that family matters during the war were described calmly. ${ }^{14}$

\section{DIVERSITY OF WAR TIME EXPERIENCES}

Almost every family in the region had its own trauma during the three months of the front in the region, between December 26, 1944, and March 16, 1945, when soldiers of the Red Army attacked the local population and environment. Every family, every village had its own particular position, experiences, atmosphere, and emotions connected with the front.

It is extremely important that although the region can be considered as uniform, every village had a peculiar story to tell about the front. It is important that while Lizi's family lived and still live in a small Swabian village nestled in the South Vértes, the kin of József K. lived and still live in a manor on the south-eastern slopes of the hills, a place that is now a small town of minor importance. During World War II his hometown was in a special situation as it was under Russian occupation from the first to the last day of the front, unlike other settlements that changed hands several times. On the other hand, although there were Russians in Lizi's village, the front stretched between the village and the puszta ${ }^{15}$ belonging to it. Apart from a few exceptions, the village suffered little, while terrible things happened in the pusztas. Families were often split between the village and the pusztas: some lived in the former, others in the latter. Thus family histories made and maintained a connection between the different fates of the village and the pusztas. ${ }^{16}$ In spite of the fact that life in the village was calm throughout the time of the front, several families recall their memories of the front in a tragic way because of family members who lived in the pusztas. As a result, the tragedy became a collective fate in many respects (connected with the front and deportations), even if tragic events did not occur everywhere. Some of the pusztas suffering tragedies gradually became depopulated after the war, as the part of the population that was not deported moved to the village. 
It is not only the location of a village that matters, since even within a village there were parts that suffered considerably during the front while other parts survived without significant losses. This could have happened, for example, if half of the village was evacuated by the Russians to the east and the other half by the Hungarians to the west, their respective hinterlands. In another village Russian troops invading it from the south-east caused enormous devastation in the part of the village inhabited by Lutherans. By the time the Russians arrived on the north-west side of the village, they calmed down and the Catholic population living there did not suffer or witness similar devastation. Moreover, not only villages and parts of villages (Csiga, Alvég, Tobán, Sík, Rigó, etc.) but also streets and, since sometimes a single street constituted almost the entire village, even parts of streets had their own histories. In other words, the situation varied even within villages. People had no knowledge about what happened to people at the other end of the village. Knowledge was generally restricted only to the immediate vicinity (two, three, at most five houses away) and possibly to the places where close relatives lived.

To what extent a given family suffered during the war was also determined by the location of their home, whether it was centrally or peripherally located. Another important factor was the infrastructural opportunities that the Russians saw in a certain place or object or how they thought they could make use of the individual capabilities of certain people. The central location of an "office" or the availability of a spacious room for the commander were important considerations for choosing a location for command. The hosts were expelled to the stable or the cellar, but in return all of the family members enjoyed protection. The camp kitchen was installed in a spacious yard and local people worked there for food and protection. A veterinary hospital for horses was established on the outskirts. Being an interpreter was also valuable. The life of many depended on their positions within the community of former World War I prisoners of war or whether they had been persecuted as possible holders of communist views.

It was not always the result of force when someone was helpful to the occupying troops. Experiences in the rural operation of the arrow-cross movement (the redistribution of valuables confiscated from the Jews) formed the behavioral mechanisms of some people.

There were some who, out of self-interest, were willing to serve the Russian troops. They hoped to get valuables (personal belongings, luxury clothing, etc.) confiscated by the Russians from others. Others were fearful of the dangers threatening their families, and sacrificed themselves and were willing to make compromises that they would have otherwise fiercely opposed. With these deeds, sometimes even unconsciously, they saved the lives, the health or the integrity of several family members and neighbors. 
Often these situations were so complicated that they can only be interpreted as "accidental", "luck" or "fate". One of the reasons for this is that details are generally known only to members of the local community. This local community can be an area, a village, part of a village, a street, part of a street or even a group of people or a family who found shelter in a cellar. In this connection, we can, for example, think of the fate of a settlement belonging to a Swabian village, where half of the male population perished on March 15, 1945, when the front passed through the region. Contrary to the public view propagated by local politicians, survivors' reports do not describe executions or deliberate destruction. We have to add that the above statements are also supported by the fact that the atmosphere created by deportations after the war and the permanent presence of Russian troops in the region suppressed any possible discussion of those events. On the other hand, very few people have survived who are knowledgeable members of these communities and could talk about these events in the region.

Only with the considerations of the diversity of war time experiences discussed above in mind can we interpret the motives of the three families and their feelings towards the Russians. Lizi's anger towards them was rooted in the humiliation suffered by one of her family members during the war. She used the same tone of voice when talking about the cruelty of the Russian officers towards the Russian soldiers. The Hungarian civilian population usually sympathized with the soldiers rather than the officers. It is also important to note that this was a balanced view that was usually typical of the mentality of the local population since their sympathy for the soldiers was balanced by their antipathy towards the officers. ${ }^{17}$ In contrast, József $K$. talked about the Russians in a moderate and neutral tone and this included events during the period the frontline remained in the region as well as those that he experienced later in the Russian barrack. László K. had no anger towards the Russians, as his father was a prisoner of war in France where he had a paid job working on a farm. He used his savings to buy a piece of land. In short, if there was positive talk at all about World War II, it was in his case, since the later success of his family was based on a transaction in which László K.'s father capitalized on his situation as a prisoner of war and made his fortune in a rural environment that suffered from shortages after the war. 


\section{THE CASE OF LÁSZLÓ K.}

My reason for visiting László K. (born in 1943) was that after the war his father established his own plant nursery by the airport, at the site of the future helicopter landing area. The plant nursery itself, as a form of private enterprise, was already interesting but I was also curious about the experiences of father and son during the times when the Russians got control of the airport, settled in, and even developed it further. At first, László K. told me about the natural conditions of the area, about the opportunities, and problems they and the Russians had to face in the proper maintenance of the airport. He told me about their work in the nursery and what he and his father grew there. He also told me about the circumstances under which they had to leave the area when the Russians appeared. They had to leave because it was felt that they could keep too close an eye on every movement of the Russians. Finally, he described in detail at what other places his father worked as a gardener later on. At this point he suddenly remarked that he had a collection of World War II artifacts that he would be pleased to show me. At first, I did not make much of this offer, even though this sudden change of topic took me by surprise.

Later, when I visited László K. to see his World War II artifacts, he filled the tops of two pig-slaughtering wooden tables with German, Russian, and Hungarian helmets, rifles, machine guns, mines, RPGs ${ }^{18}$ and other items. He added that he had more of these in the shed but he could fit only this many on

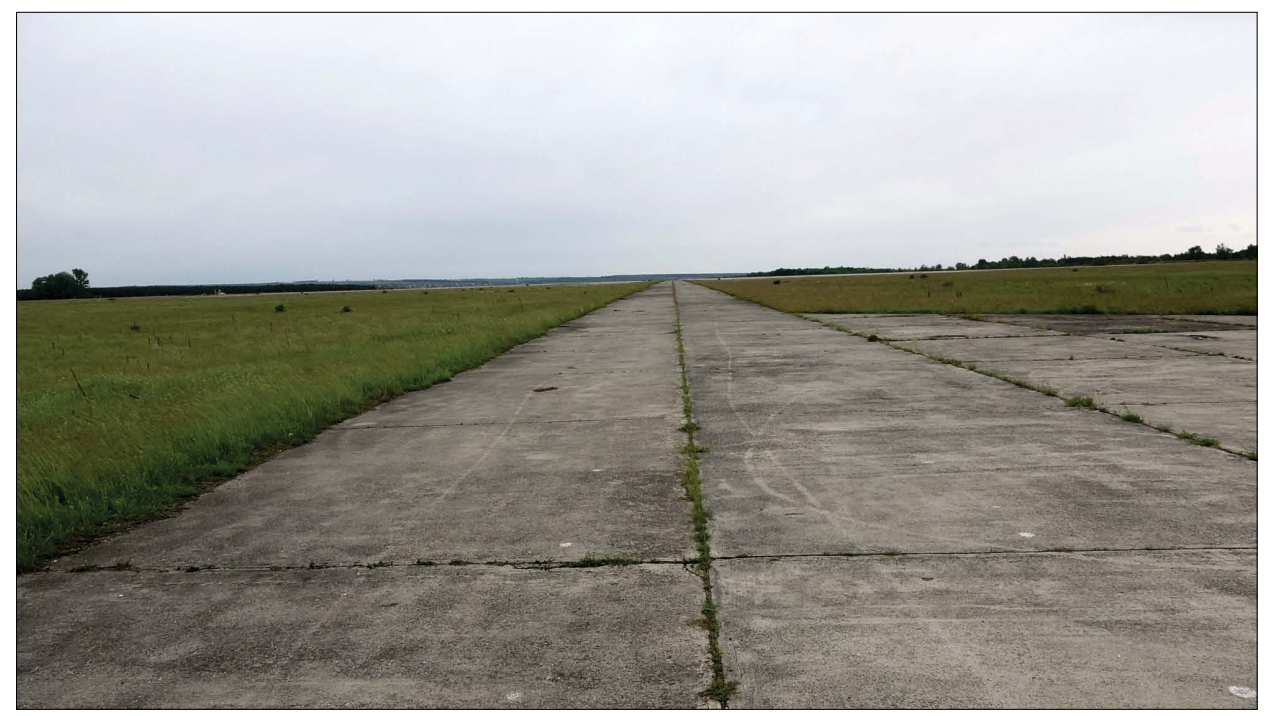

Figure 6. Airfield. Photograph by István Sántha, May 2016. 
the tables. He was telling me about the individual artifacts, which ones belonged together, and how and under what circumstances he had found them. He told me that after the $1990 \mathrm{~s}$, like some other men in the region, he had started to search the area with a metal detector in his spare time. In 2003 one of his friends asked for his help in searching for a still usable smoke mine, which they found. His friend transported the mine to his home in Csepel, in one of the southern districts of Budapest, where in his garage the mine exploded and his friend died.

Asked whether he was still acquiring new pieces for his collection, he replied that he had not gone digging for some time. After the above-mentioned tragedy, he also found a mine that started to go off at the place where he found it. He got lucky because only the fuse worked but not the explosive. The smoke and the loud sound frightened him. He promised himself he would give up his hobby and stop searching the area for war artifacts: he would rather live.

\section{STORYTELLING AND GENERATIONS}

As we can see, the connection between the two (Russian) contexts (Soviet soldiers in the war and after the war in the region) goes both ways, as storytellers can shift contexts in both directions. Even if they only want to describe the Russian barrack members of the same generation, they inevitably look for connections with the war. This was apparent when József K. recalled his faint memories of the war or when László $\mathrm{K}$. drew my attention to his war relics.

On the other hand, through these stories the folklore storytelling technique of a certain generation was revealed. An important characteristic of this storytelling is that members of the generation born during the war seek connection among different "Russian contexts". "Russian" becomes a buzzword referring to apparently very different contexts. This means that for other generations (the older generation can have conscious firsthand experiences, while younger generations have no experiences of their own and, as a result, there are no emotional effects, even indirect, in their storytelling) these barriers are either not present or these people do not need to overcome mental barriers because as the members of the post-war generation they did not live during or right after the war and could not have witnessed the destruction caused by the war, or because although they were members of the generation from before the war they did not suffer any traumas. In other cases (of the members of the generation from before the war), barriers to storytelling were almost impossible to overcome, and these people could not abandon themselves to the emotional flow of the process of storytelling. 
At this point, we have to mention the tragedy of the "generation" (if they can in fact be called a generation) of people whose very existence was connected to the events of the front: they were born from the (forced or voluntary) sexual relationships between local women and soldiers. I know of four cases in which the fathers were Russian soldiers, and some cases where local women had children with German soldiers. For some reason that is hard to determine, their mothers decided to keep the children, even though women who were raped were given the opportunity to have abortions. We can only guess the mothers' motivations for such a decision, and we cannot completely exclude the possibility that positive emotions also accompanied the otherwise sad situation. They might have hoped that their husbands and families would understand, and that they would accept the unpleasant situations since these women had suffered for their families, being subjected to the atrocities instead of them. Maybe these women did not choose to have abortions because of religious reasons or simply because their pregnancies had developed to a stage where abortion was not an option. The fact that the parents are not alive anymore makes any research on this topic hard. Family members can only pass on rumors or background information and often their emotional motivations are opposite to those of the people in question. Moreover, in the South Vértes region, people who had been born out of wedlock were rarely willing to give interviews. They ended up on the periphery of society, and sometimes they moved to locations several hundred kilometers away or lived in the local vineyard. The secrets were nearly impossible to completely uncover, as these people hesitated to talk, just as their mothers did not want to talk about the horrors they had suffered.

At this point we should emphasize the main mechanism shaping the attitude of the local population towards the Russians. Both during and after the war, the most important aspect seems to have been the rigid structure within the Russian military society. Another feature is that at both times the local population sided with one party or another. However, it is interesting that the roles switched. During the time of the front, the officers were usually positive figures; people could hope for protection from the officers from the unscrupulously devastating Russian military hordes. On the other hand, after the war it was the soldiers and not the officers with whom the local population sympathized. As in the case of Lizi, we see that the locals maintained a sort of conflict between these two strata of Russian society, even if only in their narratives, perhaps as a way to weaken the occupiers. In regard to the characteristics of this method, we also have to stress that this stratum of Hungarian society was not hostile towards the Russians: they noticed and talked about their positive features. 


\section{CONCLUSION}

In conclusion, referring to the title, and returning to Augés anthropological interpretation of Nora's concept of place of memory (lieux de mémoire), an important issue is the role of the anthropologist if there are obviously points of reference, but they are officially non-existent and undocumented, only existent in oral communication and discourse. ${ }^{19}$ It could be a good decision, which is also a frequent anthropological approach in such situations, to simply note paradoxes without aiming to resolve them (Navaro-Yashin 2012; Pedersen 2011). In our case this means that we work on a historical topic without creating a history. It cannot be our task as anthropologists to make history visible when the purpose of constructing the object was secrecy.

We can say that by using these contexts (historical, local, and military), discussed in detail above, for interpretation we could get a glimpse of the mechanism of handing down knowledge within a family. This could be used to share stories witnessed in a peculiar way by the storytellers. However, due to the age of the storytellers at the time of the events, they could not have possibly directly remembered the events; the stories were only part of the family folklore. Every family had its own attitude towards the front and the Russians, depending on where, in which village and how they survived the critical times. There are those, such as Lizi, whose families became victims of violence. Others, such as József K., did not suffer significantly. Some people were neutral and I even met people who had positive impressions in connection with the appearance of the Russians. These motives and emotions are reflected in the way different families told their stories about other topics involving the Russians, such as the Russian barrack operating in the region after World War II.

As a result of the Russian presence in the region, in an area where every family had its own history and experiences of the war, people are still not willing to talk about these events. On the other hand, absurdly, through their contacts with the Russians they could live out these emotions and later, when the Russians left the region, it was possible to talk about these emotions in a direct way. The bond between the different Russian contexts remained. In my opinion, the mechanism of storytelling is much more complex than just who talks about his or her war experiences or who does not talk about them. It is not possible to model the mechanism of storytelling in such a simple way, but we can still get a glimpse of the mechanisms at work in the case of members of a given generation, and also of how different epochs are connected to one another in order to conceal or live through traumas. 


\section{ACKNOWLEDGEMENTS}

This article was translated from Hungarian by Tímea Takács. The article is based on research conducted within the framework of the project "History of Hungarian Countryside 1944-1990", carried out in cooperation between the Research Centre for the Humanities at the Hungarian Academy of Sciences and the Committee of National Remembrance.

\section{NOTES}

1 Here I need to explain how I have used the "I" and "we" pronouns in this article. I have used "we" to refer to previous common fieldwork or to previous common publications in collaboration with Tatiana Safonova. I have used "I" when I describe a fieldcase in which I worked alone. I have used "we" generally to involve the reader in my text, to make it feel like our common product. And finally, sometimes I have also used "we" because I want to avoid using the passive voice.

2 There were also traumatic cases with German and Hungarian soldiers, although these cases remained hidden because of the Swabian and Hungarian local peoples' empathy and solidarity with the German and Hungarian armies and soldiers.

${ }^{3}$ Among others, this also holds true for the author, for whom this region was one of the important venues of his socialization, as his parents had owned and cultivated a small vineyard two kilometers from the Russian barracks.

4 This does not exclude the possibility that the connection can be regarded as almost trivial, since Russian troops stationed in Hungary were representatives of the victorious power, and maintainers of the newly established order. They were morally responsible for the events on the front if they connected themselves to those who took part in the events on the Russian side. This is the connection that is implicitly expressed with the use of the storytelling technique. This is equivalent to the silence of the members of the previous generation or to the fact that after the 1990 s members of the same prewar generation started to talk about the atrocities they had suffered.

5 It should be noted that cautious behavior was also observed in this case, for on almost every occasion there were some who tried to save these objects or calm people down to avoid revenge or lynching. These deeds were weighed positively when accounting for the crimes committed during the 1956 revolution.

6 At the end of the 1940s and at the beginning of the 1950s, trials were initiated by local communists or their relatives against local nationalists. These trials were based on accusations that "nationalists" attacked "communists" during World War II. These trials were sometimes delayed until 1956 and continued after 1956.

7 Obobshchennyi bank dannykh "Memorial"(OBD "Memorial”): a website for documents about soldiers of the Red Army who disappeared during World War II. Available at https://www.obd-memorial.ru/html/index.html, last accessed on September 21, 2017. 
8 See also some footnotes herein about similar questions concerning the withdrawal of the Russian troops in 1991 and the lack of land registry maps of the affected regions.

9 According to Gregory Bateson's anthropological terminology, "frame" and "metaframe" (Bateson 1972; Safonova \& Sántha 2013: 12-13).

10 The two apparently unrelated traumas may be connected by motifs. One motif might be aggression, since the boy was present when his mother was fleeing from the violence of the Russians. He might have been one year old at the time, so he can be considered to belong to Aunt Lizi's generation. The other connection between the two traumatic events might have been the sexual aspect. The boy was mentally disabled from his childhood but the extent to which this was caused by the traumas he had suffered during the war was unclear. He worked casual jobs; for example, for the forestry department together with his mother. On pay days he often disappeared and later he was found among dubious figures in the county seat. He had a wife, though they did not stay together for long and did not have any children. Then he became interested in his own sex. Under unclear circumstances he was strangled by his last partner after a sexual intercourse.

11 Neighbors and relatives hid from the Soviet soldiers in cellars. The members of cellar communities had symmetric or complementary positions as participant-sufferers or observer-witnesses; they and only they were truly able to understand the experiences, emotional involvements in events and atrocities.

${ }^{12}$ For similar reasons it was not a good idea if a Russian soldier captured by the enemy returned after he was released. Not only during but also after World War II, confidence in these soldiers was shaken. Former prisoners of war were not considered proper and useful members of society. People believed that they could only have stayed alive by betraying their fellows and their country, and that they may have been roped in by foreign secret services and in fact might still be working for them. This sort of suspicion was even stronger in the case of officers. When the war broke out, those who were considered dangerous to Russian society had to volunteer for service on the front, where they were used as "human shields" to provide temporary protection for other units fighting behind them. It was a general practice that victims of the Stalin repression who had been sent to gulags before the war had to return to their place of exile after their service at the front ended; they were released and could return to their families and loved ones only after Stalin's death in 1953 (see, among others, Aleksievich 2015 [1985]).

${ }^{13}$ According to presently available data, in 1946 nearly a thousand people from the village were deported. Today 600 people live in the village (Schmidt 2003).

${ }^{14}$ In connection with the absence of any atrocities in his family, when referring to the war I inquired when the first time was that he saw a dead man; it was not the war that he mentioned but the bombings before the war.

${ }^{15}$ A puszta in Hungary is the same as a steppe in Eurasia and a prairie in America. Nevertheless, the word also has another meaning: an economic farm owned by aristocrats. This connects with a more recent meaning: a couple of houses located outside the territory of the village (sometimes five to ten kilometers from each other); administratively a puszta is not an autonomous unit, but belongs to the village. 
${ }^{16}$ For example, some members of a big family lived in a puszta while other members lived in the village. Close relatives of puszta people could always be found in the village, which provided very practical opportunities for both sides. Gathering firewood and breeding animals (for example pigs) were easier from the puszta, while shopping and going to school were easier from the village.

17 The atrocities that occurred on the front were mostly committed by irregular forces, especially in the days after the occupation. In this situation, it was only the permanent presence of officers that could ensure some protection for the local population, if they were able, in some way, to gain the sympathy of an officer. This protection lasted only as long as the officer was stationed there and his authority among the soldiers was not damaged by, for example, getting wounded.

${ }^{18}$ Abbreviation in Russian for a hand-held armor-piercing grenade launcher.

${ }^{19}$ Here I need to express my special gratitude to Elo-Hanna Seljamaa, one of the editors of this collection, for supporting me in elaborating this idea.

\section{REFERENCES}

Aleksievich, Svetlana 2015 [1985]. U voiny ne zhenskoe litso. [War's Unwomanly Face.] Moscow: Vremja.

Augé, Marc 1995. Non-Places: An Introduction to Supermodernity. London \& New York: Verso.

Augé, Marc 2002. In the Metro. Minneapolis: University of Minnesota Press.

Bateson, Gregory 1972. Steps to an Ecology of Mind: A Revolutionary Approach to Man's Understanding of Himself. New York: Ballantine Books.

Humphrey, Caroline 1979. The Uses of Genealogy: A Historical Study of the Nomadic and Sedentarised Buryat. In: Equipe écologie et anthropologie des sociétés pastorales (ed.) Pastoral Production and Society / Production Pastorale Et Société. Proceedings of the International Meeting on Nomadic Pastoralism, Paris, Dec. 1-3, 1976. Cambridge \& New York: Cambridge University Press, pp. 235-260.

Mészáros, Márta 2014. A láthatatlan generáció 1-2. [Invisible Generation, series 1-2.] Budapest: Cameofilm.

Nagy, Béla 2002. A gánti bauxitbánya története. [The History of the Bauxite Mine in Gánt.] Unpublished manuscript.

Navaro-Yashin, Yael 2012. The Make-Believe Space: Affective Geography in a Postwar Military. Durham \& London: Duke University Press.

Obobshchennyi bank dannykh "Memorial". [Comprehensive Databank "Memorial".] Available at https://www.obd-memorial.ru/html/index.html, last accessed on September 13, 2017.

Pedersen, Morten A. 2011. Not Quite Shamans: Spirit Worlds and Political Lives in Northern Mongolia. Ithaca \& London: Cornell University Press.

Polgár, Péter A. 2007. Sorsom ezt így rótta ki... Történetek az 1945 és 1956 közötti idôszakból. [Inflicted by My Fate... Stories from the Period between 1945 and 1956.] Budapest: Kornétás kiadó. 
Romsics, Ignác 2003 [1999]. Magyarország története a XX. században. [History of Hungary in the 20th Century.] Budapest: Osiris.

Sacks, Harvey 1992. Lectures on Conversation, Volumes I \& II. Oxford: Blackwell.

Safonova, Tatiana \& Sántha, István 2010. Different Risks, Different Biographies: The Roles of Reversibility for Buryats and Circularity for Evenki People. Biography, Risk and Uncertainty. Forum Qualitative Sozialforschung / Forum: Qualitative Social Research, Vol. 11, No. 1. http://dx.doi.org/10.17169/fqs-11.1.1430.

Safonova, Tatiana \& Sántha, István 2013. Culture Contact in Evenki Land: A Cybernetic Anthropology of the Baikal Region. Leiden \& Boston: Brill \& Global Oriental. https://doi.org/10.1163/9789004254237.

Sántha, István 2016. A front emlékezete: A Vörös Hadsereg kötelékében tömegesen és fiatalkorúakon elkövetett nemi erôszak kérdése a Dél-Vértesben, elótanulmány. [The Memory of the Front: The Question of Mass Rape and Rape against the Youth Committed by the Soldiers of the Red Army in the South Vértes Mountain in Hungary, a preliminary study.] In: Gábor Csikós \& Réka Földváryné Kiss \& József Ö. Kovács (eds.) Váltóállitás: Diktatúrák a vidéki Magyarországon 1945-ben. [Dictatorships in Rural Hungary in 1945.] Budapest: MTA-BTK-NEB, pp. 119-154.

Sántha, István \& Safonova, Tatiana 2011. Az evenkik földjén: Kulturális kontaktusok a Bajkál-vidéken. [In the Land of Evenki: Culture Contact in the Baikal Region.] Budapest: Balassi Kiadó.

Schmidt, Helmut 2003. Unser Schicksal: Erinnerung an die Heimatvertriebenen aus Gánt / Ungarn und den umliegenden Dörfern im Vértesgebirge bzw. Schildgebirge (Stand). Unpublished manuscript. 


\title{
LIFE WITH SOVIET TROOPS IN CZECHOSLOVAKIA AND AFTER THEIR WITHDRAWAL
}

\author{
Prokop Tomek \\ Military History Institute Prague \\ Czech Republic \\ e-mail:prokop_t@yahoo.com
}

\begin{abstract}
The withdrawal of the Soviet Army from Czechoslovakia and dealing with its consequences has taken twenty-five years. Drawing mainly on archival sources, this contribution gives a short overview of the historical background, and the development and current situation of dealing with the difficult heritage of selected former military facilities. The foreign military presence deeply influenced the general attitude of the current Czech population towards foreign military presence. Among the many sites of Soviet military deployment, Milovice and Ralsko, discussed in this article, are distinctive examples, as they show both the opportunities for and limits of the recovery of former military sites.
\end{abstract}

Keywords: Czechoslovakia, military intervention 1968, Milovice, post-Soviet base, Ralsko, withdrawal

This paper is devoted to the Czech experience of the Soviet Army's over twenty years in Czechoslovakia and its consequences.

The Soviet occupation period of 1968-1991 represents an indisputably great trauma in the memory of the Czech society. Till now, Czech historiography has focused almost entirely on two key moments. The national resistance at the beginning of the occupation, in August 1968, has been celebrated as a moral victory and a time of national unity. The second event that has received considerable attention is the withdrawal of Soviet troops in 1991, which is likewise associated with liberation and victory (Macek et al. 1990 [1968]; Pecka 1996a). There is a general desire to forget about the time between these two moments because it is regarded as a period of weakness, progressive resignation, injustice, intimidation, and crime.

Research into the Soviet occupation years in the Czech Republic has been unsystematic, focusing almost entirely on the beginning and end of the Soviet military presence: 1968 and 1990-1991. At the beginning of the 1990s, the 
Institute of Contemporary History of the Czech Academy of Sciences carried out historical research on political, military, and historical aspects of the Soviet occupation. This undertaking resulted in the compilation of valuable documents. Several shorter studies dealt with casualties during the first months of the Soviet military presence in 1968 (Belda \& Benčík \& Pecka 1994a, 1994b, 1995; Benčík 1995; Benčík \& Pecka 1994; Benčík et al. 1995; Benčík \& Paulík \& Pecka 1999; Felcman 1995; Felcman \& Volková 1994). However, the period from 1968 till 1991 has hardly received scholarly attention, and only one postgraduate student in the last ten years appears to have chosen to examine the complete period of Soviet deployment in Czechoslovakia (Horák 2016). The main reason for this lack of interest has presumably been the scarcity of relevant open archival sources. There are also hardly any public sources (municipal chronicles, central and local media, etc.) that were not manipulated for propaganda purposes. But the reason could be partly due to Czech scholars' aversion to dealing with inconvenient and shameful aspects of their country's past.

This article, part of the research project "Czech society and the Soviet army 1968-1991", is based on a multi-year study of fatalities which occurred during the Soviet occupation that involved Soviet troops stationed in Czechoslovakia. I was able to access the documents of the plenipotentiary of the Czechoslovak government for temporary deployment of Soviet troops in Czechoslovakia, a valuable archival source that was made available only in 2012 . This material was used in a book focused on the description of fatalities and basic facts related to the Soviet military stay in Czechoslovakia (Tomek \& Pejčoch 2015).

While this study is primarily based on archival research, I have made two basic observational research trips to the Milovice area. On the first trip, I was there one day in September 2016, guided by a resident of Milovice, and I visited plenty of objects: ruins, reconstructed houses, and objects under repair. On the second trip, in May 2017, I was guided by a group of military heritage enthusiasts. Between my two visits, the ruins of at least two large objects were demolished: a large mess hall and an indoor swimming pool with remnants of special training equipment, including a pressure chamber and a facility for underwater rescue. I should also mention my actual first visit to Milovice. During the performance of my compulsory army service in 1986, I took a trip to the Soviet town of Milovice with my military unit as part of a friendship contact.

The research project "Czech society and the Soviet army 1968-1991" continues and includes other methods as well. Members of our team, sociologist Marie Černá and historian Michaela Tučková, have conducted several interviews with inhabitants in Milovice. The results of these interviews will be published during the next three years. 


\section{THE MILITARY INTERVENTION IN 1968 AS A STARTING POINT}

Soviet forces entered Czechoslovakia for the first time in 1944-1945, repelling the Germans, whose occupation had begun in 1939. Approximately 120,000 Soviet soldiers died during the liberation of Czechoslovakia from the German occupation. This fact, along with the general recognition of the Soviets' important role in the liberation of Czechoslovakia resulted in the local population's genuine sympathy for the Soviet Union and sense of gratitude. This mood prevailed not only in public discourse but was widespread among inhabitants of the country from May 1945 to August 1968.

The Warsaw Pact troops' intervention in Czechoslovakia in August 1968 is a well-known event (Czerwinski \& Piekalkiewicz 1972; Eidlin 1980; Skilling 1976). It has been estimated that more than 200,000 troops invaded Czechoslovakia from Germany, Poland, Hungary, and the Soviet Union. Approximately $90 \%$ of them were Soviet troops (Povolný 2010). Czechoslovakia was not prepared for such an attack (Fig. 1). The idea of putting up resistance to the Soviet Union, at that moment "the greatest friend and brother", was completely unacceptable to Czechoslovak political leaders. For twenty years the life of the whole country had been closely coordinated with the Soviet Union. But the reasons for non-resistance were political, ideological, and practical as well. Soviet partners were well informed about all the important facts needed to defend a country from foreign aggression. Yet, despite the lack of military

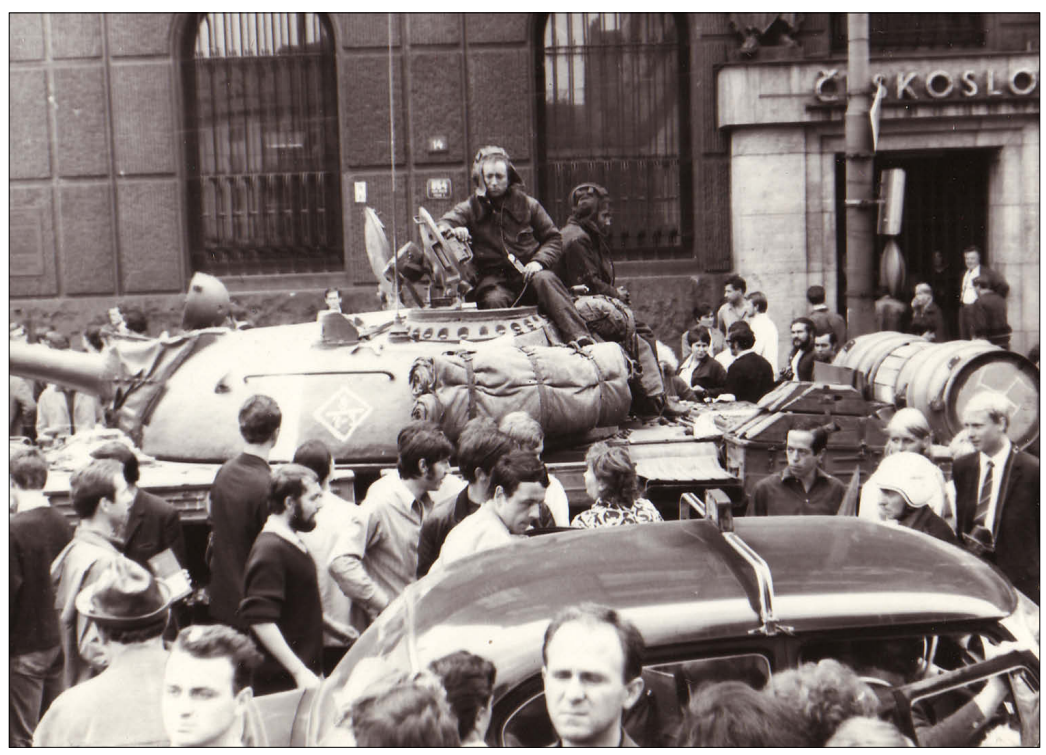

Figure 1. Soviet tanks in Prague, August 1968. Military History Institute Prague, 1968. 
resistance, the first months of the occupation of a defenseless country cost the lives of at least 135 Czechoslovak citizens, most of whom were arbitrarily shot or killed during many traffic accidents (Tomek \& Pejčoch 2015).

The reasons for the Soviet occupation of Czechoslovakia were not only the need to restore a Moscow-style political system and to maintain Czechoslovakia as a firm part of the camp of socialist states. Another important reason for intervention was to create an opportunity to deploy forces in Czechoslovakia as a southern part of the "Western Theater" of military operations in Europe. Soviet forces had been deployed in Czechoslovakia only from May to November 1945. Although Soviet soldiers committed many crimes during this short period of time, this fact did not change the overall picture of Soviets as liberators (Hubený 2013). After November 1945, Czechoslovakia was the only country in Eastern and Central Europe without Soviet military presence, if we do not count Soviet military advisers, of whom there were several hundred.

\section{CITIZENS' REACTIONS}

When discussing the Czech experience of Soviet occupation, it is important to look at changes in citizens' attitudes over time. In the first year after August 1968, almost $100 \%$ of inhabitants opposed the intervention, including those who up to the occupation had been deeply devoted to the Soviet Union. Czechoslovak politicians promised citizens that there would be a withdrawal of the Soviet troops after things had calmed down and that there would be a continuation of reforms (Tüma et al. 1996). Students comprised the most radical part of the society. They protested not only against foreign occupation but also against slowly rising defeatist moods among the general population. This period ended in August 1969, when security and armed forces violently crushed the first anniversary citizens' protests and the parliament quickly passed a law instituting severe penalties for disturbances of public order. Students called for the defense of citizens' rights. In November 1968, university students in Prague organized a huge work strike. In January 1969, a student, Jan Palach, sacrificed himself in an effort to lift people from their apathy and resignation. On January 16, 1969, in Wenceslaus Square in Prague, he suddenly poured petrol over his body and ignited himself. After three days of suffering, he died (Blažek et al. 2009: 39-89).

But citizens' attitudes deteriorated during the next couple of years. Party and society purges followed, in which the key question was: "What is your opinion of the Warsaw Pact intervention?" The politically correct answer was: "The entry of the armies was an act of fraternal help". Communist leaders gave a large part 
of the society, mainly blue-collar workers and representatives of the favored class, the opportunity to present themselves as having been confused at the time of the intervention, and to express regret for their former "wrong attitudes". Only "ideologically guilty" people, supporters of democratic reforms during the Prague Spring, and active opponents of the Warsaw Pact military intervention, were punished. Cadre purges were extensive: between 1968 and 1970, almost 500,000 people were expelled from the Communist Party of Czechoslovakia, which amounted to $30 \%$ of the members (Hradecká \& Koudelka 1998).

The majority of the population succumbed to passivity during the next couple of years, with many people taking advantage of purges and seizing vacant positions. How quickly peoples' opinion changed is illustrated by the fact that the decline in communist party membership ended in 1971. In 1988, the Communist Party of Czechoslovakia had 1.7 million members, meaning that $15.4 \%$ of the inhabitants of the country over eighteen years old belonged to the party (Hradecká \& Koudelka 1998).

Cadre purges affected not only party members, but everyone who had supported democratic reforms during the Prague Spring period of 1968. Active reform supporters were persecuted. They were fired or transferred to lower work positions. In a state with compulsory employment and the state as the sole employer, even second-rate jobs were difficult to find for these people.

The Soviet occupation had a heavy impact on national memory and morale. The massive intimidation of inhabitants resulted in the prevalence of passivity and defeatist moods. A part of the society, in fact, even after the Soviet intervention of 1968, could not forget two decades of devotion expressed to Soviet soldiers for the liberation of the country and the Soviet casualties in 1945 (Horák 2016: 49).

\section{HOW WERE THE SOVIET BASES IN CZECHOSLOVAKIA ESTABLISHED?}

Foreign military units taking part in the intervention left the cities and towns in autumn 1968. Most of them returned to their origin bases abroad. On October 16, 1968, the Soviet Union and Czechoslovakia signed a treaty for the temporary deployment of Soviet forces, according to which 75,000 troops were to be stationed in Czechoslovak territory. Soviet officers were accompanied by more than 30,000 family members. The name of the treaty was misleading, given that the date of withdrawal was left undetermined. A joke circulated by locals at the time captured the situation: Jaká je jednotka dočasnosti? Jeden furt (What is a unit of temporariness? It is one forever). 


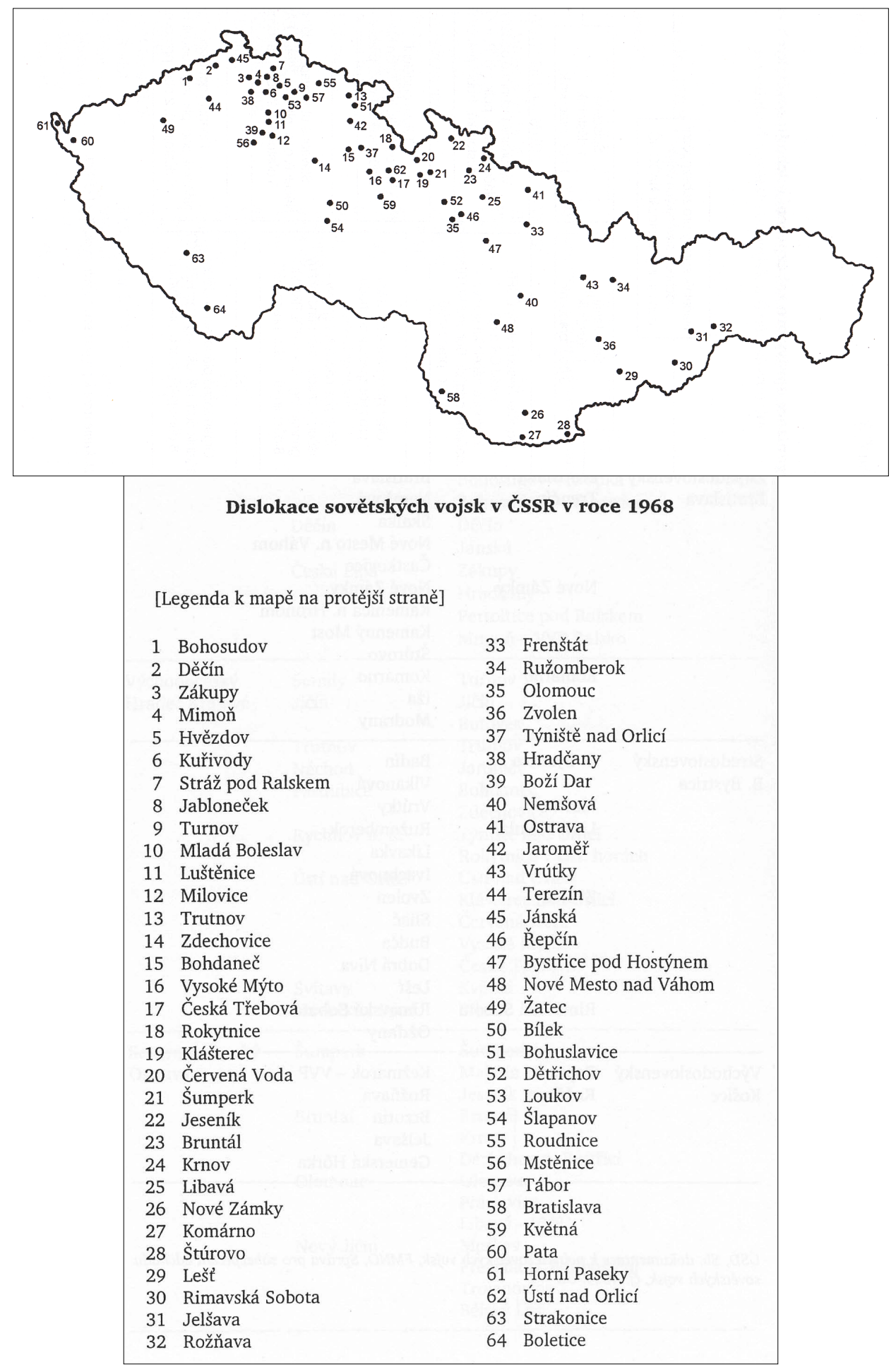

Figure 2-3. Central Group of Forces in Czechoslovakia (Pecka 1996a). 
At the beginning of the occupation in August, Soviet political leaders promised that troops would be withdrawn after securing the socialist system in Czechoslovakia. But very soon, in September and October 1968, it became clear that the Soviets wanted to deploy their troops in Czechoslovakia for at least a couple of years. Once a firm pro-Soviet regime had been established, nobody even raised the question of withdrawal.

The Central Group of Forces (CGF - the official name of the Soviet military contingent in Czechoslovakia) took over some of the military bases of the Czechoslovak Army. The latter had not created any of the zakrytie gorody (closed cities) found in the Soviet Union. And there were also no special apartment buildings within military bases, as was customary in Soviet garrisons. Most of the Soviet troops were deployed in the western and central parts of the republic, i.e. the Czech part of the Czechoslovak Republic, because it was closer to the enemy in the West. Only a small number of the forces were stationed in Slovakia. Altogether five army divisions and two air force divisions were deployed in Czechoslovakia. Compared with other countries of the Soviet bloc, the Central Group of Forces was about the same size as the South Group of Forces in Hungary. The Central Group of Forces was not so well equipped and was smaller than the Western Group of Forces in Germany (Nad'ovič et al. 2005).

For more than twenty years, Soviet forces were deployed on thirty-three bases, four airports, three military hospitals, six large storage areas, and five training areas (Pecka 1996a: 285-289) (Fig. 2 and 3). There were five army divisions. Two divisions were located in central and northern Bohemia, one division in eastern Bohemia and northern Moravia, one in northern Moravia, and the last division was deployed in Slovakia. The Group of Soviet Forces included one air division. Two airfields were located in northern and central Bohemia, one in northern Moravia and one in Slovakia.

Almost all Soviet military bases were located in small towns and villages. In Prague and Bratislava there were only small communication or liaison units. There were two headquarters: the main one in Milovice, to be discussed below, and the headquarters of the 28th Army Group in Olomouc.

\section{LIVING TOGETHER OR LIVING AUTONOMOUSLY}

The life of the Soviet Army personnel was hidden from the Czechoslovak public. It was contained almost entirely within the walls of military barracks and bases (Fig. 4). The rank-and-file troops could leave military barracks only in organized groups. As a rule, they did so for cultural purposes or for celebrations of political anniversaries, such as May 1 or the anniversary of the Great October Socialist Revolution on November 7. Soldiers also could leave military bases 


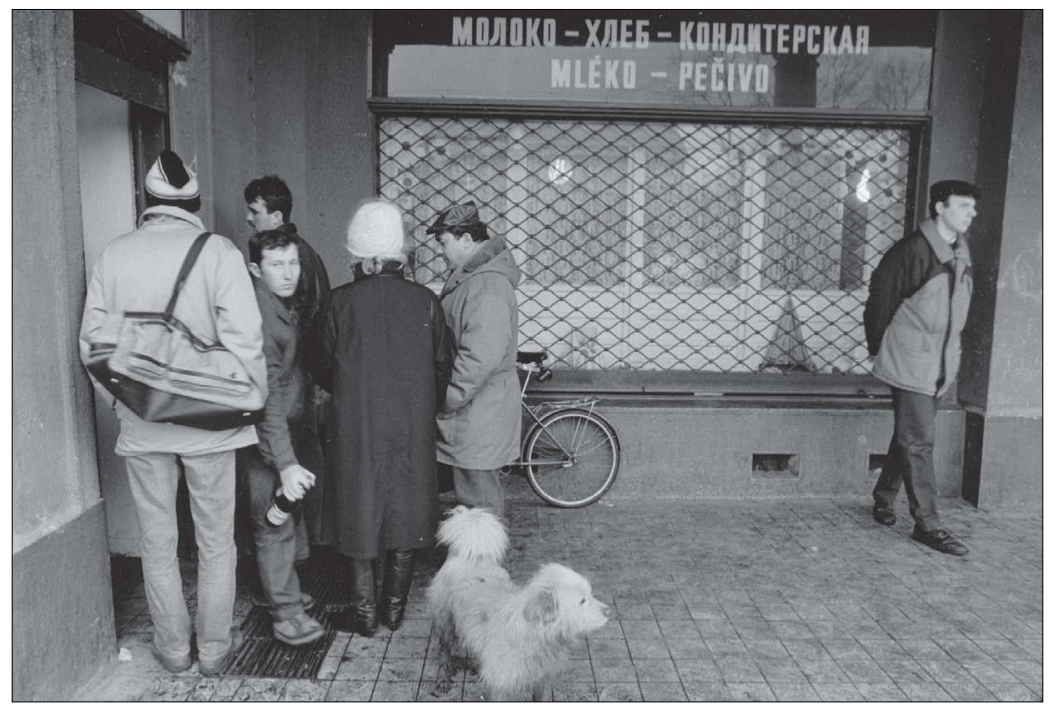

Figure 4. Everyday life of Soviets in Milovice in the late 1980s. Military History Institute Prague (photograph by Jan Jindra).

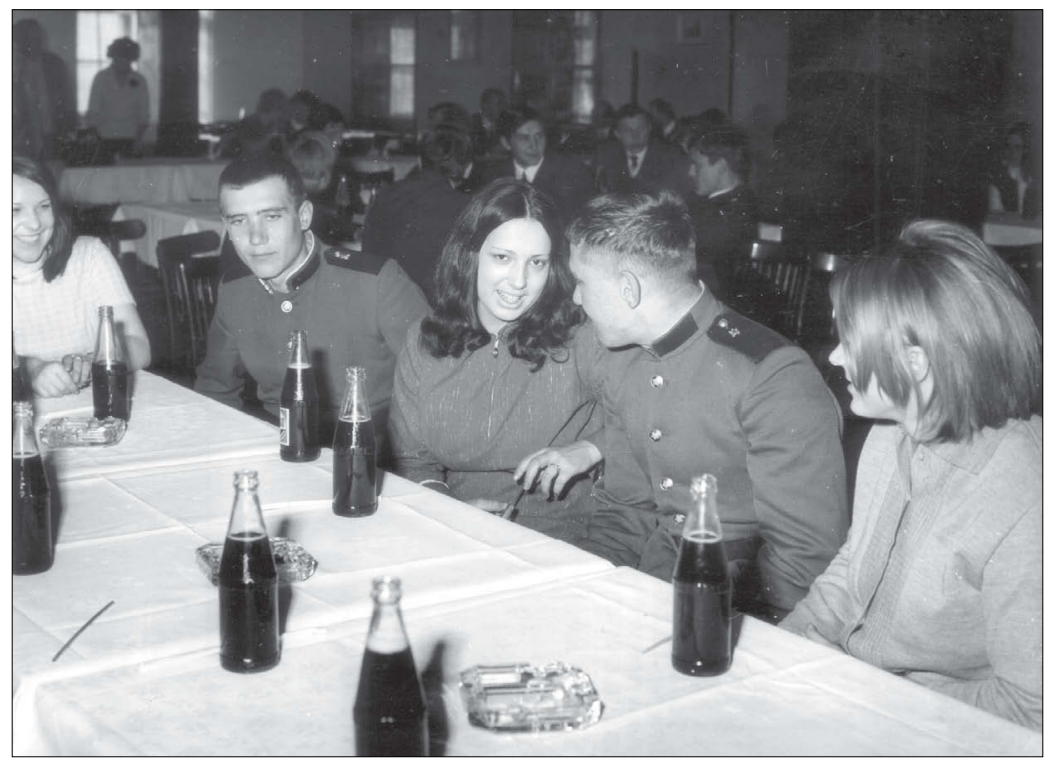

Figure 5. Arranged meeting of apprentices from the south Moravian region with Soviet rank-and-file troops in the 1970s. Military History Institute Prague. 
in order to provide help in construction, harvests or industry. These were occasions for meeting Czechs and Slovaks informally. Only officers and their family members could move about freely in shops, streets, and other public spaces. A small number of Czechs and Slovaks were employed at Soviet military bases.

Czechoslovak and Soviet forces lived and trained separately, meeting only in joint field exercises and organized visits (Fig. 5). No studies of this topic have been undertaken till now. Only a few isolated facts and testimonials are available (Tomek 2016). It is likely that joint activities were limited by concerns over personal conflicts between the two sides and their political consequences.

The contacts of Czechoslovak citizens with Soviet troops were limited. People usually had no desire to engage in genuine $d r u z h b a$ (friendship) with members of the Soviet military. However, taking part in official events offered a good opportunity to demonstrate favorable attitudes towards the regime. It could serve as a way of advancing individual careers and having more comfortable lives. Such organized events included meetings of young people (members of Komsomol and the Socialistic Youth Union ${ }^{1}$ ), celebrations of socialist anniversaries, and various cultural events. Such contacts were sometimes covered in the media. Ordinary people were forced to find a way to live next to Soviet troops.

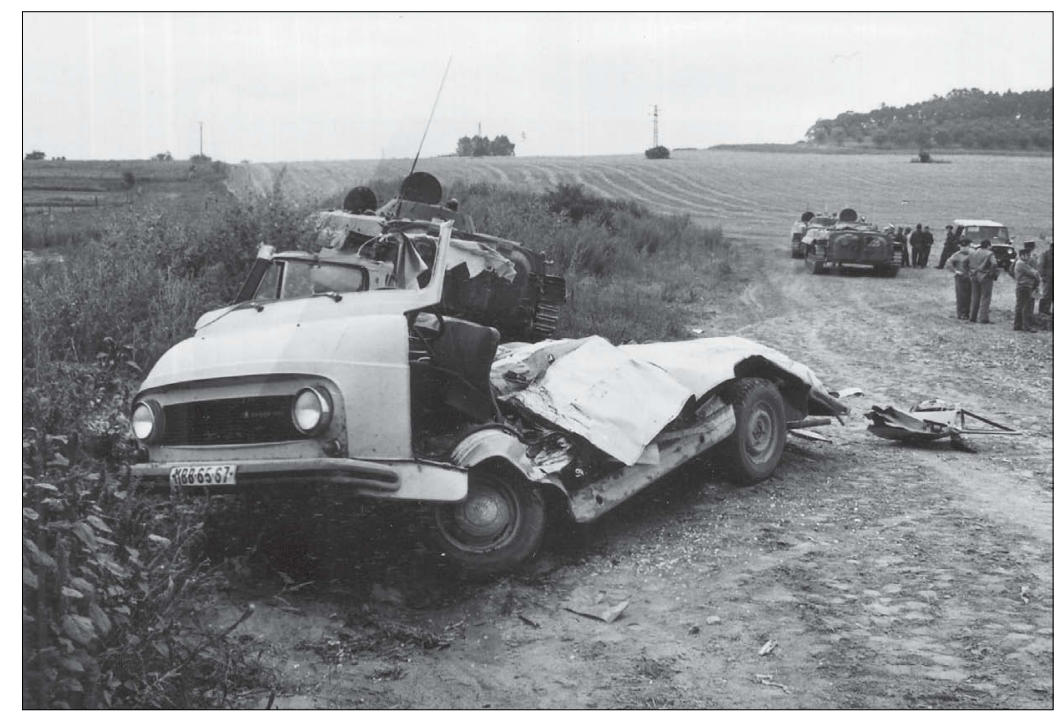

Figure 6. An example of the hundreds of more or less serious accidents caused by the Soviets. Military Historical Archive in Prague, 1982. 
Genuinely informal and vital relationships could emerge in the vicinity of Soviet military bases. These contacts were based almost entirely on "black market" needs. Some people took pity on rank-and-file soldiers during occasional informal contacts because of their poor life. On the other hand, there also were civilian victims of traffic accidents, murders, and rapes committed by Soviet soldiers or with their complicity (Fig. 6) (Tomek \& Pejčoch 2015: 78-96). During more than twenty years of the Soviet presence, there were 400 Czechoslovak citizens who died under such circumstances (ibid.: 357).

The long-term occupation gradually gave rise to a mood of hidden antipathy. Official media published nothing but positive news about visits, meetings, work assistance, cooperation, and joint military exercises (Pecka 1996b). Only exile organizations and newspapers abroad and the Charter 77 initiative $^{2}$ in Czechoslovakia protested against the Soviet military presence repeatedly. In August 1988, after twenty years of public silence, the first large demonstration took place in Prague. The reason for this public protest was the 20th anniversary of the Warsaw Pact's violent intervention in Czechoslovakia.

The withdrawal of Soviet troops from Czechoslovakia became a realistic option only after the Velvet Revolution of 1989. The demand for the withdrawal of Soviet troops from Czechoslovakia was one of the main topics on the agenda

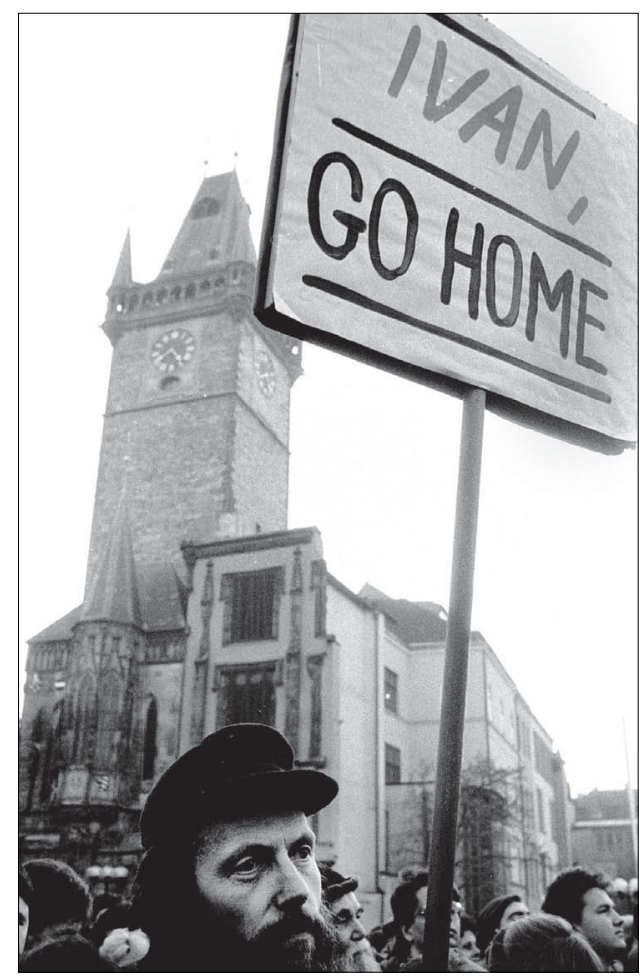
of the new democratic administration (Fig. 7).

Figure 7. Demonstration in Prague held to protest over the Soviet military presence in Czechoslovakia. Military History Institute Prague (photograph by Karel Cudlin 1990). 


\section{THE CONSEQUENCES OF WITHDRAWAL}

The exit of Soviet military forces from Czechoslovakia took one and a half years. By June 1991, all Soviet troops and their equipment were back in the Soviet Union (Pecka 1996a). The issue of the Soviet forces' withdrawal was one of the key topics during the Velvet Revolution in November and December 1989. The period of the withdrawal was relatively short due to favorable geopolitical conditions. The first session of Czechoslovak-Soviet talks took place in Prague in January 1990. At first the Soviet side attempted to prolong the presence of its forces in Czechoslovakia, referring to a lack of housing for officers' families and other social reasons, but finally accepted a deadline of June 1991. The second round of negotiations took place in Moscow the following month. On February 26, 1990, Jiři Dienstbier, a former dissident and at the time the Minister of Foreign Affairs, and Eduard Shevardnadze, the Minister of Foreign Affairs of the Soviet Union, signed a bilateral agreement in Moscow on the withdrawal of the Soviet forces from the Czechoslovak territory (Pecka 1996a).

The process of dealing with the consequences of the Soviet military presence has continued for the past twenty-five years. After the withdrawal, huge ecological damages were revealed, especially the contamination of soil in the areas used by the Soviet forces. The price of decontamination has amounted to more than one billion Czech crowns (thirty-six million euros). Demolition squads have spent years cleaning the large military training areas of Ralsko and Milovice. Dangerous ammunition was left not only in the ground but also in cesspits, sewage disposal plant tanks, boiler houses, and in deserted apartments (Pecka 1996a: 260-280). By 2001, in the Milovice area alone, around 185,000 rounds of ammunition had been found. These areas had to be cleaned before handing them over to civilians.

Former barracks and other real estate in military use could be utilized only partly. Neither the state administration nor local governments were prepared to deal with this property and with areas that had been devastated first by the Soviets, who took all of the useful items during the withdrawal because of a lack of building materials and furnishings in the Soviet Union, and subsequently by Czech metal thieves. There was no privatization law at all.

The small Czechoslovak state, which in 1993 was divided into the Czech Republic and the Slovak Republic, had also come to terms with its own military heritage: 200,000 Czechoslovak troops and their equipment had to be drastically reduced during the $1990 \mathrm{~s}$.

Some former military compounds have been rebuilt only partially. As a rule, it has been easier to use former military barracks located on the fringes or within cities. Such complexes have been successfully turned into apartments, 
schools, hospitals, administrative offices, homes for the elderly, and shops. For example, the historical city of Olomouc in north Moravia housed the headquarters of the 28th Army Corps of the CGF during the occupation. Now the University of Olomouc's administration uses more than 600 reconstructed apartments as students' dormitories and the local administration is using other apartments to house citizens. The city administration in Olomouc took over a military airfield, formerly the base of the 490th Helicopter Regiment, which now serves many civil aeronautical purposes. In the town of Mladá Boleslav, the 18th Guards Motorized Rifle Division was located. Its barracks now serve as the town hospital and are used to house pensioners and others in need of housing (see Mladá Boleslav).

\section{POST-SOVIET MILITARY ZONES: MILOVICE}

Civilian utilization of large military zones lying outside towns and cities has posed greater problems. One example of this is Milovice, located forty kilometers north-east of Prague. The military history of this region is quite long. In 1904 an artillery range of the Austro-Hungarian Army was established in this area. This training facility was at the time the most important military site in the Czech part of the monarchy. Milovice at that time was a small village, with around 1,000 inhabitants. After 1918 the new Czechoslovak Army took over the training area and during World War II it was used by the Wehrmacht. After the war, the Czechoslovak Army returned. With the exception of the Wehrmacht, all of these users were able to coexist with the civilians in the area. The Wehrmacht displaced dozens of villages for the purpose of creating a bigger military training area. Another chapter of military-civilian coexistence was opened in 1968 (Blahová 2016).

Soviet forces were deployed in Milovice for the first time from May to November 1945, after the liberation of Czechoslovakia from Nazi occupation. This fact was probably one reason why Soviet forces coming to Czechoslovakia in August 1968 very soon tried to achieve control over Milovice. Its long distance from big cities and existing military facilities promised to make it a perfect site for the most important units of Soviet forces in Czechoslovakia. On the fringes of the existing town of Milovice a Soviet military city was established, which served as the headquarters of the whole Central Group of Forces (Fig. 8). After the withdrawal of Soviet forces, thousands of apartments, a cultural center, sports fields, swimming pools, a hospital, shops, an elementary school, military training facilities, and a number of other buildings and establishments were 


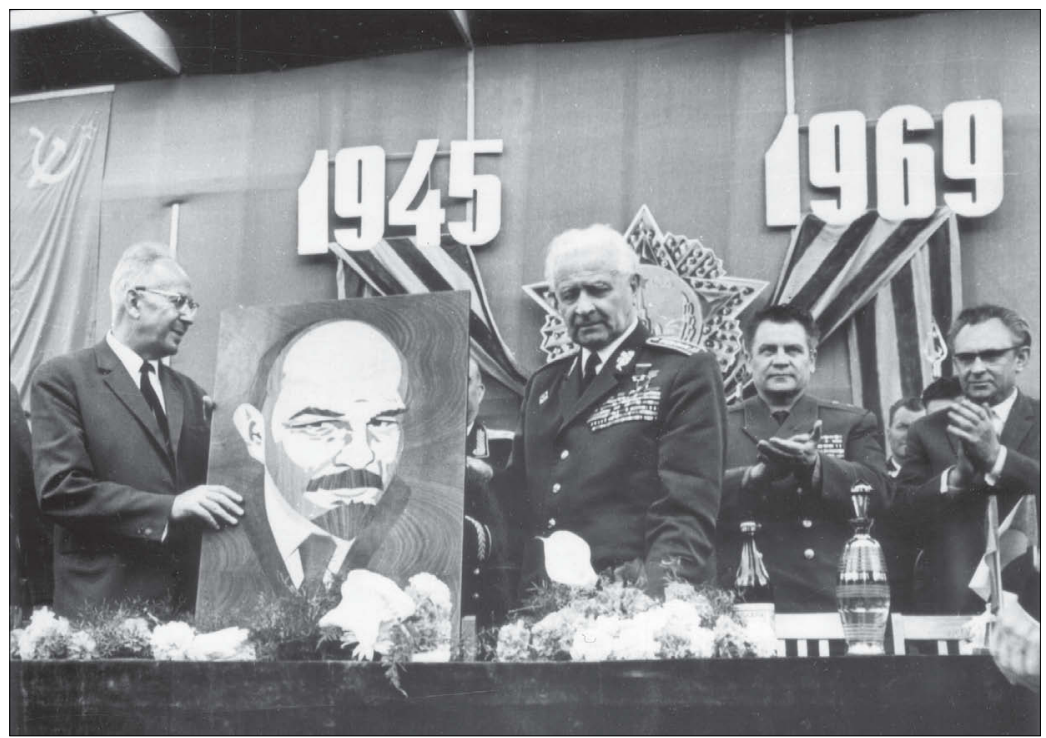

Figure 8. The first visit of political and state leadership in Soviet Milovice. Military History Institute Prague, 1969.

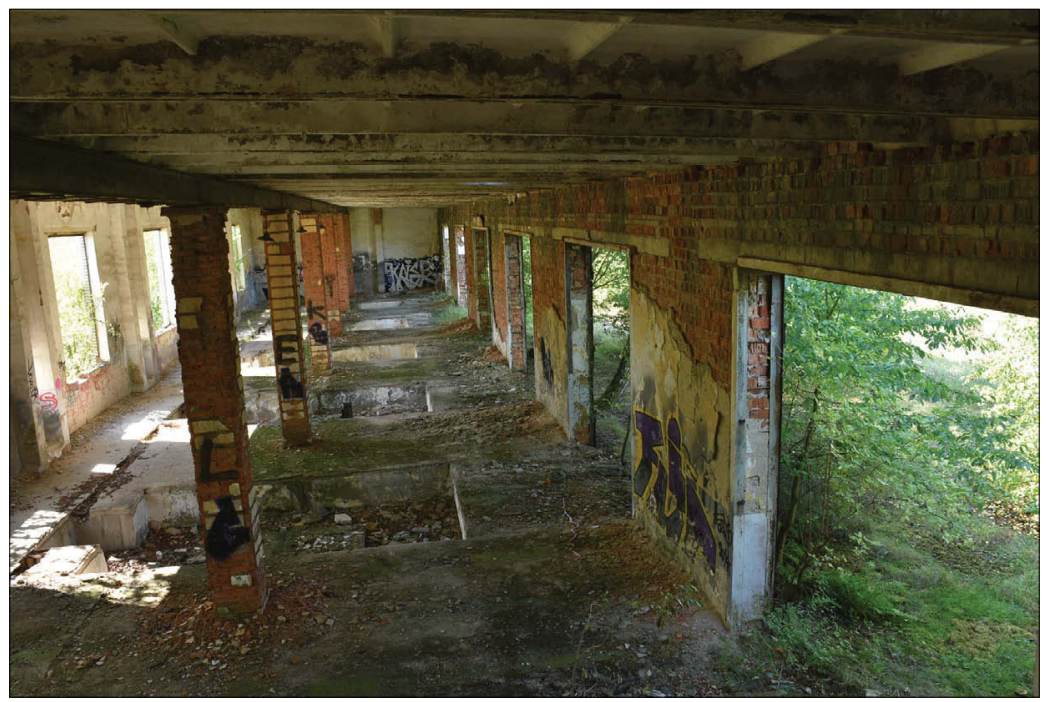

Figure 9. The town of Milovice at present. Photograph by Prokop Tomek 2016. 


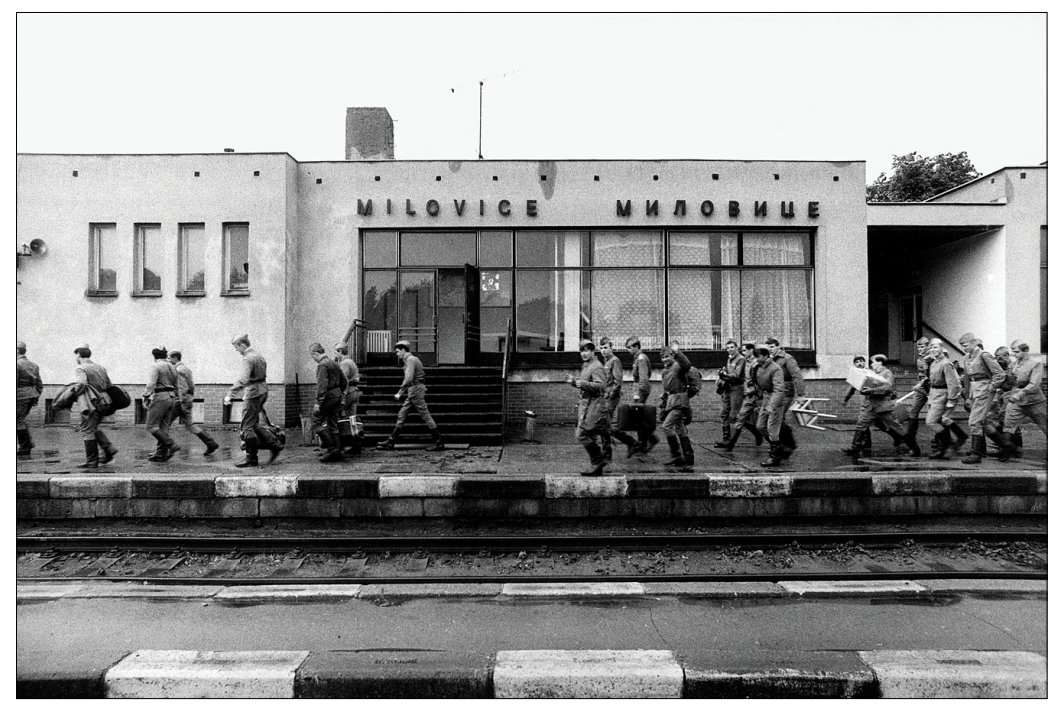

Figure 10. The withdrawal of Soviet forces from Milovice. Milovice railway station. Military History Institute Prague (photograph by Karel Cudlín 1991).

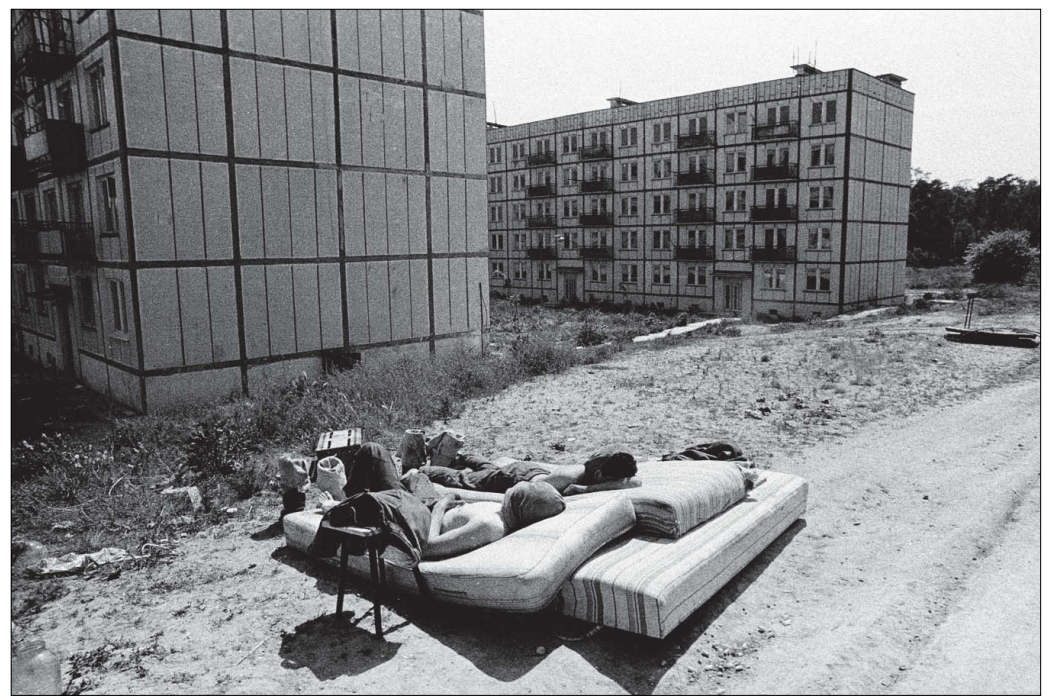

Figure 11. Concrete buildings in Milovice after the withdrawal of Soviet forces in the 1990s. Military History Institute in Prague (photograph by Karel Cudlin). 


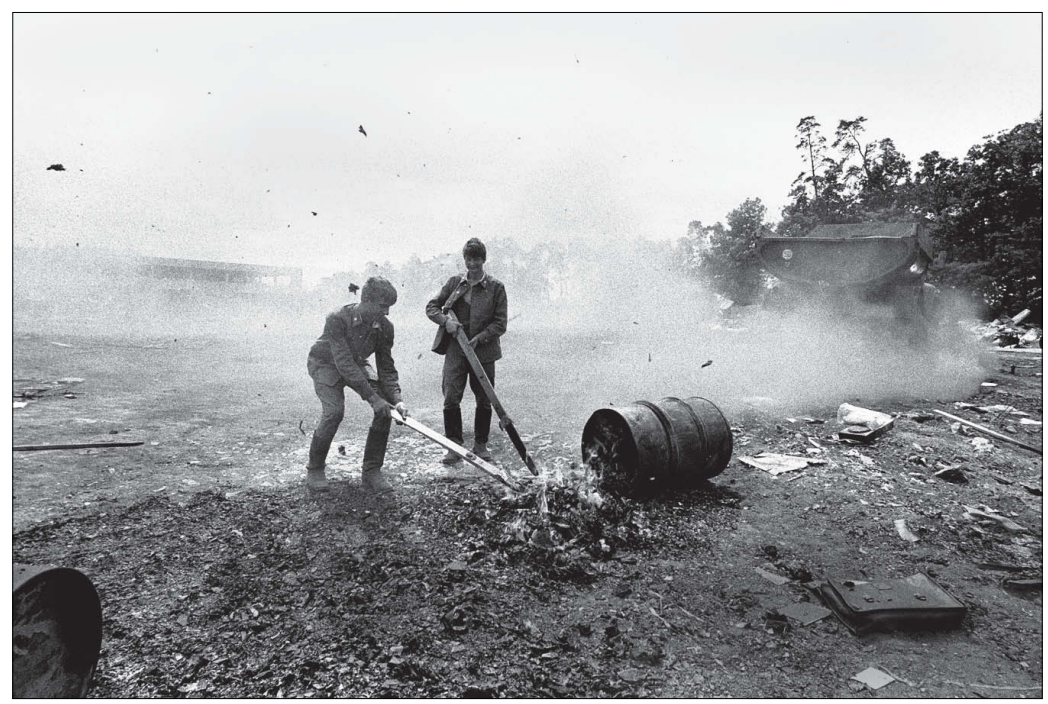

Figure 12. The general situation around military objects left by the Soviet Army in the 1990s. Military History Institute Prague (photograph by Karel Cudlin).

abandoned in the huge former military area. The majority of these facilities were seriously damaged during the past two decades (Fig. 9). Yet only one part of the area, a housing project of Soviet concrete apartment buildings in the area of Milovice-Boží Dar, near an airfield, was demolished.

The population of Milovice shrank after the withdrawal in 1991 to 1,200 inhabitants, almost all of whom had been living in Milovice since before the Soviet occupation (Fig. 10). The withdrawal was a great shock to the whole area (Figs. 11 and 12). Only a couple of months earlier, Milovice had been a town of about 50,000 inhabitants. In addition to Soviet civilians and soldiers, there were the Czech inhabitants of the old village of Milovice. Some local sources say that

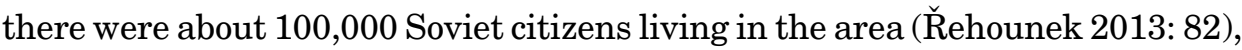
yet this is unrealistic, because this figure would have been $90 \%$ of all the Soviet soldiers and their families in Czechoslovakia. In 1990-1991, Milovice changed into a village with an abnormal heritage of property characteristic of a deserted town. It quickly became a target of metal thieves. In the surrounding forests and in ruins plenty of illegal or semi-legal activities took place, for example, rave parties, car club meetings, paintball and airsoft games, urban explorations, and techno parties, especially in the 1990s (Pohunek 2015). Some of them, for example, music festivals and military exercises, were held legally though. 
The first to settle in Milovice over the next two years were 120 immigrants from Ukraine. These people were ethnic Czech settlers from Volhynia (in the Chernobyl area), who had requested repatriation to the Czech Republic after 1989. In the course of the next two decades, the local administration succeeded in reconstructing the devastated apartments, while also launching the construction of new housing by real estate developers. More recently, Milovice has started a project to put the former Soviet airfield of Boží Dar into commercial use. Formerly there had been speculation about constructing a huge international

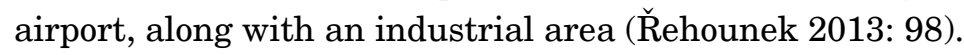

In 1991 the state proclaimed Milovice a town. Revitalization of the Milovice area is still going on today. At first, there was a lack of schools and social infrastructure. There has never been a big local employer. In 2003 unemployment reached $12.5 \%$. By 2015 , it had dropped to $6.6 \%$. There were new job opportunities in developing private enterprises in Milovice but the main reason for the falling unemployment rate was an improved connection to Prague. The railway to Prague was reconstructed at the beginning of the new millennium. In 2010 direct city trains started operating between Milovice and Prague, reducing the travel time to forty-five minutes or less. About 12,000 permanent inhabitants live in Milovice today, while approximately 2,000 more are renting temporary accommodation. There are two basic schools and four kindergartens (Město Milovice).

There was no other way to attract people to Milovice except to offer them cheap housing in a rapidly developing region that is quiet and close to nature. Over 10,000 people have moved there during the last twenty years, including many young people. Milovice's population probably has the lowest average age of any municipality in the Czech Republic. The average age of residents is thirty-five years, while the national average is forty-two years (ibid.).

How are the new settlers preserving the memory of the locality? The pupils of the basic school in Milovice have rediscovered and designated the site of the nearby village of Mladá, which was wiped out in 1904, at the time of the establishment of the first Austro-Hungarian military training area. Pupils placed information panels in the forest to commemorate the 100th anniversary of this event (Milovice). References to the Soviet past, however, are almost nonexistent. There are no marked tourist paths in the town, and no information panels presenting the past of the site. The town's website mentions only one historical site of interest regarding the Soviet past. In the town hall, the former Dom Officerov (Officers' House), there is a mosaic entitled Bojové družby se sovětskými vojsky ('The combat friendship with the Soviet forces'), which was made in the 1980s as a Czech gift to the Soviet Army, and it consists of 440,000 tesserae. It is allegedly the largest mosaic in central Europe (Milovice). 
In Milovice it is possible to see conserved architecture of the "Austrian camp": brick houses erected at the time of the Austro-Hungarian monarchy. This part of the town has remained surprisingly intact since its construction over 100 years ago and has developed a nice park-like character. The German Nazi occupation period, on the other hand, influenced the town's architecture only minimally, though the Wehrmacht destroyed some villages in the surrounding area in the course of its tactical military training activities during World War II. The Czechoslovak Army restored its presence and activities in Milovice in 1946, but during the first months of the Warsaw Pact occupation in 1968 the Soviet military leadership expressed an interest in Milovice. The reasons included good experience from the short Soviet stay in Milovice after the 1945 liberation, the town's unique isolated location, its huge airfield and the possibility of expansion.

Enterprises in today's Milovice focus more on the present or future than the past. A former training ground for tanks has been turned into an amusement and educational park called Mirakulum Park. Next to it is Tankodrom, a former tank training area where one can now ride heavy equipment through wasteland. One former Soviet building located at the edge of the large artillery range, used originally for military training purposes, has been rebuilt as a special ski simulator, unique in the Czech Republic. A safari park was opened in the target area of the artillery range: there are forty hectares of wild steppe with the remains of Wehrmacht observation bunkers. Herds of wild horses, aurochs and European bison have recently found a home in the safari park. The town administration wants to bring in more tourists. New wooden observation towers are rising at the edge of the safari park. These initiatives are being carried out by the nongovernmental organization Česká krajina (Czech Landscape) with funds from the European Union and various other parties (Česká krajina). It follows from these developments that nature and amusement will be the main attractions in Milovice, while the past receives little or no attention.

All in all, Milovice is a remarkable town. Great progress has been made in the integration of the region into the civilian world, though there still are some empty areas.

\section{POST-SOVIET MILITARY ZONES: RALSKO}

A completely different story can be told about Ralsko in the north of the Czech Republic, another former Soviet military zone. Ralsko was the site of another Soviet airfield, Hradčany, and of a military training area. An extensive bomb disposal project, lasting ten years, was undertaken in Ralsko after the Soviet 
withdrawal. The airfield with underground shelters for soldiers has been used only sporadically, mostly for the filming of war movies, including the films "Stalingrad" (1993), "Dark Blue World" (2001), and "Child 44" (2015). Rows of completely devastated concrete apartment buildings tower over the village of Kuřivody, near the airfield. Families of Soviet officers left these buildings in 1991 and they have not been utilized since due to their isolation.

The German Wehrmacht established a training area during World War II. The nearby villages of Jablonec and Svébořice have been uninhabited since 1939. While approximately 7,000 people lived in this area before World War II, today only 1,700 have remained. The hindrance to the development of the remote area of Ralsko is the lack of job opportunities. The town of Ralsko extends over an area of 170 square kilometers, which makes it the second largest urban area in the Czech Republic after Prague. But the distance between Prague and Ralsko is ninety kilometers, meaning that Ralsko is twice as far from Prague as Milovice, and there is no direct railway connection (Nováková 2011).

One important reason for Ralsko's different path of development is that this region was historically a part of the Sudetenland, and was ripped away from the rest of Czechoslovakia by the Munich agreement of 1938. After World War II its inhabitants, ethnic Germans, were expelled from Czechoslovakia. Suddenly deserted, this region was turned into a military training area, which changed its development for the next forty years and more. Such a long gap without a civilian presence is very hard to fill. The process of depopulation started in 1938 and is ongoing.

Because re-population was not an option for Ralsko, its future has been planned in terms of the local nature, which is well preserved due to this area having been in military use and closed to the public for many decades. A nature reserve for rare animals has been established in Ralsko in the territory of the former artillery range Židlov. The area of the Geopark Ralsko extends over 249 square kilometers. The main actor there is the nongovernmental organization Geopark Ralsko, which receives ample support from European funds (see the Geopark Ralsko website).

At the end of September 2016, "Sky Soldier II", a joint airborne exercise of US and Czech paratroopers, took place around the Hradčany airfield. The Czech Army leadership has announced its intention of exploring the possibility of using this area again for military purposes (Polák 2016). Whether this intention will be realized remains uncertain for now. The Czech Army got rid of many of the military training facilities during the period of geopolitical stability of the 1990s. Now, however, it seems to be necessary to improve the army's military skills. Because the Czech society has expressed little interest in Ralsko, this remote and forgotten region may well become a military zone again. 


\section{AFTER THE WITHDRAWAL}

Following the withdrawal of Soviet forces from Czechoslovakia, the Czech society adopted a negative attitude towards the new deployment of any foreign forces. Since the Czech Republic joined NATO in 1999, many short-term joint exercises have taken place in its territory. But when, in 2006, the Czech government announced its intention to allow the USA to construct an anti-missile defense system on the Czech territory, responses varied. Many were afraid that the Russian Federation would interpret the construction of an anti-missile defense system as an expression of hostility and that this could cause Russia to take dangerous action. Nevertheless, in 2008 the Minister of Defense of the Czech Republic and the Secretary of Defense of the USA signed a preliminary agreement for the construction of an anti-missile defense system. Reactions from some parts of the Czech society were openly negative, including by some anti-American groups, leftist nongovernmental organizations, environmentalists, and some political parties. According to annual reports of the Security Information Service, the Intelligence Service of the Czech Republic as well as some groups and individuals expressing discontent with the government's plan were supported by the Intelligence Service of the Russian Federation (Annual Report 2007). The most remarkable (active and aggressive) entity was a civic association called Ne Základnám! (Say no to bases!), which organized demonstrations and events. This initiative was very closely connected to the Communist Party of Czech and Moravia and to leftist NGOs. In 2009 the US administration announced that it was stepping back from its original intention to include the Czech Republic in an anti-missile defense system.

These events and reactions unfolded at a time of relative stability in Europe. At the end of March 2015, it was announced that a US Army convoy would transit the Czech territory from exercises in the Baltic states and Poland to bases in Germany. Communists and leftist organizations protested against this plan and announced that they would form blockades and demonstrations. A representative of the 'Say no to bases!' association even promised that they would use Molotov cocktails and organize violent protests (see Nová Republika). In reality, only a few protesters showed up for the actions, while thousands of people waited for the US Army convoys and spontaneously cheered the soldiers, welcoming them to the Czech Republic. This changed attitude should not be interpreted as a sign of public agreement with the prospect of deploying foreign forces or, in particular, of establishing new military bases on Czech territory. However, it does suggest that the Czech society has become more aware of security risks. 


\section{CONCLUSION}

The process of creating military bases and facilities has generally caused problems. In the Czech case, repeated experiences with foreign occupation forces have deeply influenced both the character of the landscape and the memory of its inhabitants. Towns and the environment are only very slowly being converted back into civil spaces. The speed of this process seems to depend, among other things, on the distance of former military regions from populated and cultivated areas. The history and traditions of sites during the past hundred or more years are also very important in terms of recovery. The past and present are harder to connect in places where the natural path of development has been broken for long periods. Dealing with the past in former military facilities is complex. There has not been a systematic approach to military empty areas in the Czech Republic. Approaches taken to these sites depend on local opportunities, yet what they seem to share is a reluctance or even refusal on the part of new inhabitants and local authorities to address and preserve the history of the period of Soviet military presence. Former military buildings and facilities have been reconstructed and re-utilized without references to the past. In remote localities in particular, natural resources are used to attract tourists.

I sometimes also lack the courage to look at our "inconvenient" past and to learn from it.

\section{ACKNOWLEDGEMENTS}

This article was written as part of the project "Czech society and the Soviet army 1968-1991" supported by the Grant Agency of the Czech Science Foundation (project no. 17-06744S).

\section{NOTES}

1 Socialistic Youth Union (a Czechoslovakian version of the Komsomol).

2 Charter 77 initiative: a citizens' Czechoslovakian informal oppositional group established in January 1977. 


\section{REFERENCES}

Belda, Josef \& Benčík, Antonín \& Pecka, Jindřich 1994a. Dislokace sovětských vojsk $v$ Československu 1968-1969: Materiály, studie, dokumenty, č. 6. [Displacement of Soviet Troops in Czechoslovakia 1968-1969: Materials, Studies, Documents, Vol. 6.] Prague: Ústav pro soudobé dějiny Akademie věd ČR.

Belda, Josef \& Benčík, Antonín \& Pecka, Jindřich 1994b. Polsko a vojenská intervence $v$ Československu 1968. Materiály, studie, dokumenty, č. 5. [Poland and the 1968 Military Intervention in Czechoslovakia: Materials, Studies, Documents, Vol. 5.]. Prague: Ústav pro soudobé dějiny Akademie věd ČR.

Belda, Josef \& Benčík, Antonín \& Pecka, Jindřich 1995. Podíl NDR na intervenci proti Československu v roce 1968. Materiály, studie, dokumenty, č. 9. [Participation of the German Democratic Republic in the 1968 Intervention in Czechoslovakia: Materials, Studies, Documents, Vol. 9.] Prague: Ústav pro soudobé dějiny Akademie věd ČR.

Benčík, Antonín 1995. Sovětská vojska v Československu a 'mírové úsilí SSSR 1968-1973. Materiály, studie, dokumenty, č. 9. [Soviet Troops in Czechoslovakia and the "Peaceful" Effort of the USSR 1968-1973: Materials, Studies, Documents, Vol. 9.] Prague: Ústav pro soudobé dějiny Akademie věd ČR.

Benčík, Antonín \& Pecka, Jindřich 1994. Mad’arská účast v srpnové invazi 1968. Materiály, studie, dokumenty, č. 4. [Hungarian Participation in Invasion in August 1968: Materials, Studies, Documents, Vol. 4.] Prague: Ústav pro soudobé dějiny Akademie věd ČR.

Benčík, Antonín \& Pecka, Emanuel \& Pecka, Jindřich \& Sarandev, Atanas 1995. Bulharsko a československá krize 1968. Materiály, studie, dokumenty, č. 11. [Bulgaria and the Czechoslovak Crisis of 1968: Materials, Studies, Documents, Vol. 11.] Prague: Ústav pro soudobé dějiny Akademie věd ČR.

Benčík, Antonín \& Paulík, Jan \& Pecka, Jindřich (eds.) 1999. Vojenské otázky československé reformy 1967-1970. Díl 6/2. Srpen 1968 - květen 1971. [Military Issues of the Czechoslovak Reform of 1967-1970. Part 6/2. August 1968 - May 1971.] Prague \& Brno: Ústav pro soudobé dějiny Akademie věd ČR a Doplněk.

Blahová, Veronika 2016. Historie bývalého vojenského prostoru Milovice a památek $v$ okolnich obcich. [The History of the Former Military Area Milovice and Monuments in Surrounding Villages.] Bachelor thesis. University of Hradec Králové. Available at https://theses.cz/vyhledavani/?search=The+history+of+th e+former+military+area+Milovice+and+monuments+in+surrounding+villages, last accessed on September 1, 2017.

Blažek, Petr \& Eichler, Patrik \& Jareš, Jakub \& Benešová, Michala \& Cílek, Václav \& Halík, Tomáš \& Hejdánek, Ladislav \& Chalupecký, Jindřich \& Jáchimová, Veronika \& Kamiński, Łukasz \& Kranát, Jan \& Kolář, Jan \& Lederer, Jiří \& Nachmilnerová, Eva \& Petrusek, Miloslav \& Putna, Martin C. \& Trojan, Jakub S. \& Vilímek, Tomáš \& Yannakakis, Ilios 2009. Jan Palach ‘69. Prague: Filozofická fakulta UK v Praze. 
Czerwinski, Edward J. \& Piekalkiewicz, Jarosław 1972. The Soviet Invasion of Czechoslovakia: Its Effects on Eastern Europe. New York: Praeger Publishers.

Eidlin, Fred H. 1980. The Logic of 'Normalization': The Soviet Intervention in Czechoslovakia of 21 August 1968 and the Czechoslovak Response. New York: Columbia University Press.

Felcman, Ondřej 1995. Invaze a okupace: $K$ úloze SSSR a sovětských vojsk ve vývoji Československa v letech 1968-1991. Pobyt sovětských vojsk na území Československa 1968-1991. Materiály, studie, dokumenty, č. 15. [Invasion and Occupation: Role of the USSR and Soviet Troops in the Development of Czechoslovakia in 1968-1971. Deployment of Soviet Troops in the Czechoslovak Territory 1968-1991: Materials, Studies, Documents, Vol. 15.] Prague: Ústav pro soudobé dějiny Akademie věd ČR.

Felcman, Ondřej \& Volková, Květoslava 1994. Co stála srpnová invaze. Pobyt sovětských vojsk na území Československa 1968-1991. Materiály, studie, dokumenty, č. 3. [What Was the Cost of the August Invasion? Deployment of Soviet Troops in the Czechoslovak Territory 1968-1991: Materials, Studies, Documents, Vol. 3.] Prague: Ústav pro soudobé dějiny Akademie věd ČR.

Horák, Zdeněk 2016. Sovětská posádka ve Vysokém Mýtě 1968-1990. [The Soviet Military Presence in Vysoké Mýto 1968 to 1990.] Unpublished MA thesis. University of Hradec Králové. Available at http://theses.cz/id/vceqhi/, last accessed on September 1, 2017.

Hradecká, Vladimíra \& Koudelka, František 1998. Kádrová politika a nomenklatura KSC 1969-1974. [Cadre Politics and Nomenclature of the Communist Party of Czechoslovakia in 1969-1974.] Prague: Ústav pro soudobé dějiny Akademie věd ČR.

Hubený, David 2013. Spolupráce Policejního ředitelství a Rudé armády na zajištění bezpečnosti ve Velké Praze a potlačení kriminality rudoarmejců. [Cooperation of the Police Directorate and Red Army to Guarantee Security in the Greater Prague and Suppress Red Army Criminality.] Sborník archivu bezpečnostních složek, Vol. 11, pp. 159-174.

Macek, Jozef et al. (comps.) 1990 [1968]. Sedm pražských dnů: 21.-27. srpen 1968. Dokumentace. [Seven Days in Prague: August 21-27, 1968. Documentation.] Prague: Academia.

Nad'ovič, Svetozár \& Foertsch, Hartmut \& Karácsony, Imre \& Ostrowski, Zdzisław 2005. The Great Withdrawal: Withdrawal of the Soviet - Russian Army from Central Europe 1990-1994. Bratislava: Ministry of Defense of the Slovak Republic.

Nováková, Klára 2011. Vojenský újezd Ralsko v letech 1950-1968. [Military Area Ralsko in 1950-1968.] Bachelor thesis. Univerzita Karlova. Available at https://is.cuni. cz/webapps/zzp/detail/87257/, last accessed on September 1, 2017.

Pecka, Jindřich 1996a. Odsun sovětských vojsk z Československa 1989-1991: Dokumenty. [Transfer of Soviet Forces from Czechoslovakia 1989-1991: Documents.] Prague: Ústav pro soudobé dějiny Akademie věd ČR.

Pecka, Jindřich 1996b. Sovětská armáda v Československu 1968-1991: Chronologický prehled. [Soviet Army in Czechoslovakia 1968-1991: Chronological Overview.] Prague: Ústav pro soudobé dějiny Akademie věd ČR. 
Polák, Michael 2016. Vojáci v Ralsku po 25 letech: Čeští a američtí výsadkáři tam budou mít rozsáhlé cvičení. [Soldiers in Ralsko after 25 Years: Czech and American Paratroopers Will Have Extensive Training.] Novinky.cz, September 19. Available at https://www.novinky.cz/domaci/414822-vojaci-v-ralsku-po-25-letechcesti-a-americti-vysadkari-tam-budou-mit-rozsahle-cviceni.html, last accessed on September 1, 2017.

Pohunek, Jan 2015. Odraz archeologizovaných krajinných prvki̊ v etnografických pramenech. [Reflection of Archaeologized Landscape Elements in Ethnographic Resources.] Diss. (PhD Thesis). Univerzita Karlova. Available at http://www. academia.edu/31086650/Odraz_archeologizovan\%C3\%BDch_krajinn\%C3\%BDch_ prvk\%C5\%AF_v_etnografick\%C3\%BDch_pramenech, last accessed on September 1, 2017.

Povolný, Daniel 2010. Vojenské řešení Pražského jara 1968, II. [Military Solution of the Prague Spring of 1968, Part II.] Prague: Ministerstvo obrany ČR. Available at http://www.mocr.army.cz/assets/multimedia-a-knihovna/publikace/vojenskahistorie/21-prazske-jaro_iidil_internet.pdf, last accessed on September 1, 2017.

Řehounek, Jan 2013. Osudové okamžiky: Sto let vojenského výcvikového prostoru MiloviceMladá. [Fateful Moments: A Hundred Years of Milovice-Mladá Training Ground.] Nymburk: Kaplanka pro Svazek obcí Svatojiřský les.

Skilling, Harold Gordon 1976. Czechoslovakia's Interrupted Revolution. Princeton: Princeton University Press.

Tomek, Prokop \& Pejčoch, Ivo 2015. Černá kniha sovětské okupace: Sovětská armada $v$ Československu a její oběti 1968-1991. [Black Book of Soviet Occupation: Soviet Army in Czechoslovakia and Its Victims 1968-1991.] Cheb: Svět křídel.

Tomek, Prokop 2016. Jiný pohled: Zpráva přidělenců obrany velvyslanectví Spojeného království v Praze za rok 1981. [A View from the Other Side: 1981 Report by the Military Attaché of the British Embassy in Prague.] Historie a vojenství, Vol. 65, No. 2, pp. 60-72.

Tůma, Oldřich \& Jaroš, Oldřich \& Koudelka, František \& Nosková, Alena 1996. Srpen '69: edice dokumentů. [August 1969: Issue of Documents.] Prague: Maxdorf.

\section{INTERNET SOURCES}

Annual Report 2007 = Annual Report of the Security Information Service for 2007. Available at https://www.bis.cz/vyrocni-zprava5819.html?ArticleID=30; https://www.bis. cz/vyrocni-zprava2645.html?ArticleID=29, last accessed on September 1, 2017.

Česká krajina. Available at http://www.ceska-krajina.cz/, last accessed on August 31, 2017.

Geopark Ralsko. Available at http://geoparkralsko.cz/en, last accessed on September 1, 2017.

Město Milovice $=$ Základní informace o městě. [Basic Information about the City.] Available at http://urad.mesto-milovice.cz/cs/samosprava/zakladni-informace-omeste.html, last accessed on August 31, 2017. 
Milovice. Available at http://volnycas.mesto-milovice.cz/cs/pamatky-a-prirodni-zajimavosti/ zanikla-obec-mlada.html, last accessed on August 31, 2017.

Mladá Boleslav = Stopy po působení sovětských vojsk jsou mnohde patrné dosud. . [Traces of Soviet Troops Are Still Visible.] Available at http://www.mb-net.cz/stopy-popusobeni-sovetskych-vojsk-jsou-mnohde-patrne-dosud/d-10749, last accessed on August 31, 2017.

Ne Základnám. [Say No to Bases!] Available at http://nezakladnam.cz/ens, last accessed on September 1, 2017.

Nová Republika. Available at http://www.novarepublika.cz/2015/03/molotovovymikoktejly-proti-americke.html, last accessed on September 1, 2017. 


\title{
THE "DEGRADED" LANDSCAPE OF A POST-SOVIET MILITARY BASE IN POLAND: OUTSIDE VS. INSIDE VIEW
}

\author{
Dominika Czarnecka \\ Institute of Archaeology and Ethnology \\ Polish Academy of Sciences, Poland \\ e-mail:d.czarnecka@hotmail.com
}

\begin{abstract}
This article focuses on the context and lasting consequences of the withdrawal of the Russian Federation military forces from the town of Borne Sulinowo in Poland in the 1990s. Combining an analysis of local and all-Polish media with interviews and observations conducted in Borne Sulinowo, the article distinguishes between insiders' and outsiders' perspectives on this former military base in order to demonstrate how degradation was as much a feature of the local natural landscape and built environment as it was a cultural and political construct serving the interests of the post-socialist state. Rather than inventorying environmental and economic damages, this article aims to present the multidimensionality and relativity of the phenomenon of degradation in the context of the landscape of a former Soviet base. By reconstructing facts, opinions, and myths related to the "degraded" landscape of a former military base, different perspectives and ways of seeing become apparent.
\end{abstract}

Keywords: Borne Sulinowo, Cold War, degradation, landscape, legacy, Poland, post-Soviet military base, ruins, ways of seeing

The end of the Cold War led to the withdrawal of the Russian Federation military forces from Central and Eastern Europe and, after the process of sociopolitical transformation started in Poland in 1989, a debate was initiated on the legitimacy and effects of Soviet/Russian soldiers having been stationed in the country for several decades. ${ }^{1}$ The final withdrawal of the Russian Federation soldiers from Poland took place on September 18, 1993. The process of the withdrawal of the Russian Army began with the exit of the tactical ballistic missile brigade from Borne Sulinowo on April 8, 1991. In the first quarter of 1990, a commission chaired by Deputy Prime Minister Leszek Balcerowicz ${ }^{2}$ evaluated the initial losses resulting from the stationing of the foreign military forces in Poland. The analysis conducted at that time demonstrated that 
the largest economic losses were caused by: 1) the free access that soldiers of the Northern Group of Forces of the Soviet Army (NGF SA) (later, the Russian Army) had to the agricultural and forest land (military training grounds, airfields, artillery ranges, etc.); 2) non-compliance with the Polish laws related to environmental protection; and 3) the use of residential buildings and other structures (Krogulski 2001: 181). ${ }^{3}$

After 1993, mass media and scientific publications repeatedly released the following information:

In many places... after the Russians' departure the landscape resembled a battlefield. Roofs were ripped off the buildings, doors and window frames were devastated, window panes were smashed, radiators, bathtubs, toilet bowls were removed, even the high voltage lines were pulled out. Everything that had any value had been stolen and sold at markets or taken away to Russia. The rest, being useless, was barbarously ruined. (ibid.)

Although such descriptions were not entirely unfounded, the reality of the situation was more complex.

In this article, I analyze the problems related to the legacy left by the Soviet/ Russian soldiers on the former military bases in Poland, based on the example of Borne Sulinowo. This settlement, located in northwestern Poland (in the West-Pomeranian Voivodeship), was one of the largest and strategically most significant staging centers of NGF SA soldiers in Poland in the years 1945-1992.

The history of Borne Sulinowo is usually divided into several stages: the German civilian settlement Linde (from the sixteenth century to the 1930s), a German garrison (1933-1945), a Soviet garrison (1945-1992), and a Polish civilian town (from 1993 until now) (see Demski \& Czarnecka 2015: 96-120; Czarnecka 2015: 21-40). ${ }^{4}$

My aim is to reconstruct facts, opinions, and myths related to the "degraded" landscape of the former military base (I will return to the concept of degradation below ${ }^{5}$ ) through a juxtaposition of two perspectives. The "outside view" is related to narratives which emerged on supra-local levels and, in order to piece them together, I draw on information that appeared in the Polish national and regional press in the first half of the 1990s. The "inside view" is connected with the bottom-up experiences and memories of the inhabitants of Borne Sulinowo, and I recall them on the basis of interviews conducted in the field. ${ }^{6}$ From the point of view of the present analysis, yet another important source that often juxtaposed both perspectives, was the local newspaper Moreny: Gazeta Krainy Jezior i Lasów (Moreny: The Paper of the Land of Lakes and Forests), published in Borne Sulinowo in the years 1993-1996. ${ }^{7}$ 
Borne Sulinowo, located on Lake Pile and surrounded by forests, is often called "a forest town" or "the pearl of the Drawsko Lake District". Borne Sulinowo's location, with the town's natural and landscape values, is relevant from the point of view of the topic of degradation and environmental issues. It is a suitable example for exploring these issues.

In the text, I focus on the real and imagined problems that were related to the process of degradation of the landscape of the Soviet/Russian military bases in Poland, in an attempt to answer the following questions: What was the purpose of presenting the post-Soviet bases as "degraded" landscapes? What features were associated with such a type of representation? Does a "degraded" landscape contain in itself a capital that might be used in relationships with other agents? What were the strategies of presenting the foreign military forces on the local and supra-local levels in the context of the degradation process? Is a "degraded" landscape only a condition or is it also a way of seeing? In fact, the aim of this analysis is not to provide a description and an accurate inventory of the actual scope of damages and contamination, but rather to attempt to present the multidimensionality and relativity of the phenomenon of degradation in the context of the landscape of a former military base. "Degradation" reveals itself as a cultural construct.

\section{SOVIET GARRISONS IN POLAND: A HISTORICAL OVERVIEW}

In contrast to the allied forces, which after the end of World War II withdrew from the liberated territories, the soldiers of the Union of Soviet Socialist Republics (USSR) remained in Poland for over forty years. ${ }^{8}$ As early as June 1945, by order of Josef Stalin, a separate military structure was established under the name the Northern Group of Forces of the Soviet Army. Its existence was officially justified by the need to secure a back-up base for the Group of Soviet Forces in East Germany and transport routes between the USSR and Germany. Unofficially, each Soviet unit stationed in Poland was considered by Stalin to be a force which might support military operations in Western Europe (see Potyrała 1995: 117-127; Golon 1999: 37-115).

Until the early 1990s, the number, distribution, and type of Soviet units stationed in Poland was kept secret. At present, it is known that in the years 1945-1956 the number of Soviet soldiers in the country decreased from approximately half a million to less than 100,000. The agreement on the legal status of Soviet troops temporarily stationed in Poland was signed only at the end of 1956 , which means that in the years 1945-1956 NGF SA soldiers were stationed in Poland solely based on Stalin's personal decision. The breakthrough connected 
with the introduction of legal regulations was closely related to the turbulent events of the "Polish October" and the riots in Hungary. Nikita Khrushchev, who in 1953 assumed the office of First Secretary of the Central Committee of the Communist Party of the Soviet Union, was aware of the need to review the policy of the USSR towards "allied states" in Central and Eastern Europe.

The first legal regulations concerning the number and location of foreign troops were introduced on October 23, 1957, when the governments of the Polish People's Republic (PPR) and the USSR signed an agreement on the number, location, and procedure of movements of Soviet troops temporarily stationed in Poland. The document stipulated that the number of Soviet soldiers would not exceed 62,000-66,000, and that they would be located in thirty-nine garrisons (Fig. 1). ${ }^{10}$ In practice, there were many more garrisons and military units. The Soviets gradually decreased their number, reaching a level approximate to that stipulated in the agreement by the end of the 1980s. Their military garrisons were located (with a few exceptions) in the western part of Poland: in Lower Silesia, Western Pomerania, and Western Greater Poland (Krogulski 2001: 33-56).

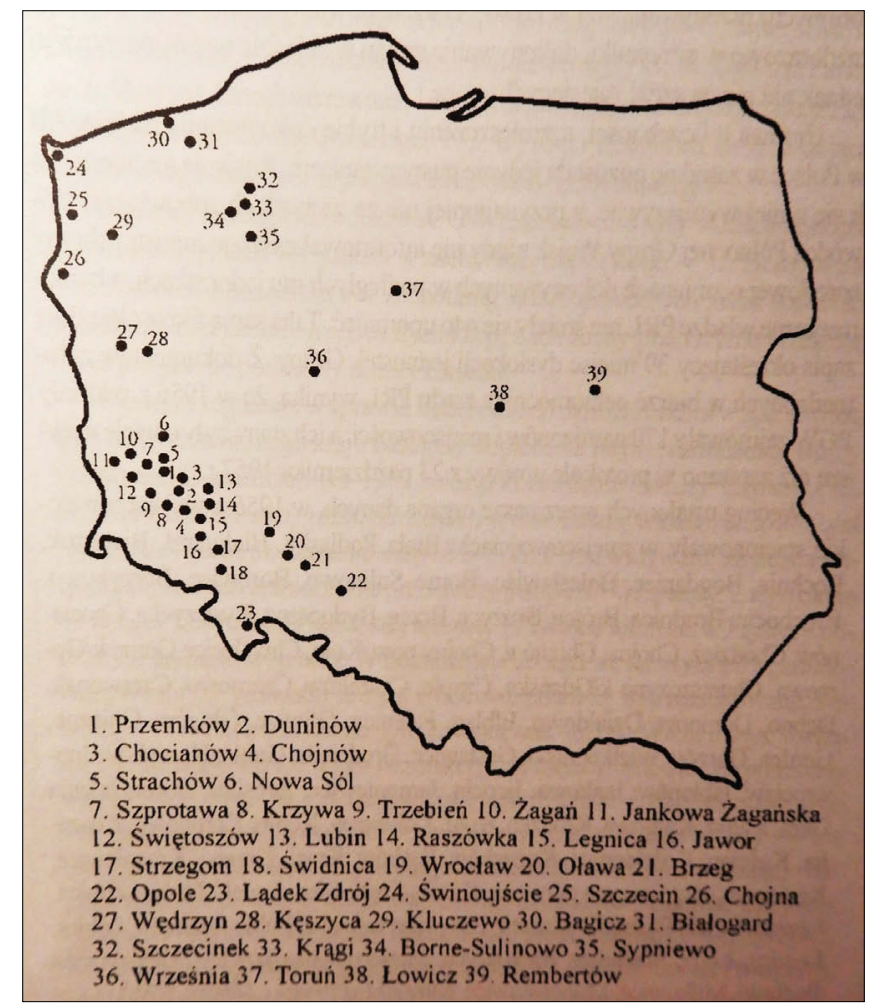

Figure 1. Thirty-nine Soviet garrisons in Poland. Archive URM. BPR, sygn. 2511/24 Vol. I. 
Although the German garrison in Borne Sulinowo was taken over by the Soviet Army in 1945, officially the soldiers of the 6th Guards Vitebsk-Novgorod Motor Rifle Division started being stationed there in 1947. In the Soviet military period, the location of the base among woodlands served mostly strategic purposes. For decades the military base was not marked on civilian maps, and one can read in Polish tourist guides about the time when the area near Lake Pile was inaccessible and unattractive. However, the secret settlement unit, apart from a railway line, had rather good road connections with major regional centers, such as Szczecinek (twenty-two kilometers) and Koszalin (ninety-five kilometers), and to the south, with Wałcz, Piła, and Poznań (Małachowski \& Szymańska 1994: 5). Until the time of the withdrawal of 10,000 Russian troops in October 1992, the whole area had an ex-territorial status and thus was excluded from the control and jurisdiction of the Polish administration. It is also worth mentioning that Soviet nuclear weapon depots were located in Brzeźnica, near Borne Sulinowo. ${ }^{11}$ For decades both the PPR authorities and the Soviet military denied the existence of nuclear weapons in Polish territory. Only in the early 1990s (at a conference held on April 7, 1991, i.e. the day before the first military units started to withdraw from Borne Sulinowo) was their existence officially confirmed by the commander of the NGF SA, General Viktor Dubynin. However, he did not specify their location at that time.

\section{“DEGRADED” LANDSCAPES AND PLACES}

In Poland in the early 1990s the concept of degradation was frequently used in the context of the post-Soviet bases by supra-local and local media. According to the Dictionary of the Polish Language, the verb zdegradować ('to degrade') has several meanings. In the context of the present analysis three of them are worth mentioning: 1) to cause destruction of the natural environment, 2) to decrease the value of something, and 3) to deprive of rank or dignity. Although the first meaning appears rather self-explanatory (it denotes all kinds of pollution and contamination of the ground, water, air, flora and fauna, with consequences visible or invisible, caused by human activity), the difference between the remaining two meanings may be somewhat unclear (and their semantic fields may overlap and complement each other). Therefore, I have used "the decrease of something's value" mostly in the economic sense. The result of degradation can be seen in a decrease in land value or real property prices, a lack of investors, the withdrawal of capital or decreasing interest in a place. The third meaning is related to the symbolic dimension and I understand it as a withdrawal or loss of a former position or role, the redefinition of meanings and concepts, or 
marginalization. In extreme cases, degradation may involve gradual destruction or even attempts at total annihilation.

Thus, the adjective "degraded" is assigned with negative value and is used to denote subjects/objects which have had the faith placed in them destroyed, applicable standards or patterns breached, or a specific function fulfilled but not up to outside expectations. More often than not, something suffering from degradation cannot be adapted to ongoing changes and, in effect, has to be "controlled" so as not to threaten the functioning of the orderly structure and development of self-reflexive systems with its distinctness. This distinctness is, then, perceived as a threat, a risk, something that needs controlling by way of warnings and prohibitions, something that is brushed aside, marked, limited, or suppressed. A reflection of this is seen in the synonyms of the verb "degrade" in the Polish language: to contaminate, to pollute, to poison, to destroy, to corrupt, to impoverish, to decrease the standard of something, to devalue, to depreciate, to beat, to defeat, to inflict heavy losses, to depose, to level down, etc.

Degradation does not happen naturally or by itself. Apart from the parameter of time, whose influence may intensify or limit the development of the process, and the effects of degradation, also present are the degrader and the degraded. Therefore, at least two sides are involved in the process of degradation, the sides being linked in the framework of a specific structure through various types of power relations. ${ }^{12}$ Moreover, within given hierarchies, the degrading side occupies a place at least one level above the degraded one. As degradation is based on belittling or even attempts at the elimination of what does not meet the imposed criteria, the process may be connected with the double mechanism of gratification-punishment (Foucault 1995 [1977]: 180-181). In the case of degradation, the weight is shifted towards the field of punishment. Representation of the opposite pole can be seen in a promotion, nomination, increase in rank, etc.

Change is written into the process of degradation (even if the degrading side assumes that degradation is ultimately aimed at preventing a change). Change, apart from being linked with various levels of structure, directly affects the degraded side, influencing its previous status, which decreases. As a result, the degraded side often becomes more vulnerable. However, imposing the need for reorganization and in the face of dealing with a new situation, instead of resulting in an intensification of the fall of the degraded side, degradation may lead to its discovering/triggering resources hitherto unknown, a reevaluation of meanings, and involvement in new networks and relations.

"Degradation" can be related to landscapes and places. For the purposes of this analysis, the notion of landscape is understood as a set of empirically defined objects, which are saturated with cultural myths and meanings, hidden convic- 
tions, and ideas of cultural seeing. Thus, landscape "implies a more-than-human materiality; a constellation of natural forms that are independent of humans, yet part and parcel of the processes by which human beings make their living and understand their own placing in the world" (Lund \& Benediktsson 2010: 1).

"Degraded" places, such as the ghost town Pripyat in Ukraine or Kłomino in Poland, generate specific landscapes, and have much in common with "countersites" (contre-emplacements) (Foucault 1984: 46-49). "Counter-sites" are places which contradict the spaces that surround them, forming a kind of dent in an ordered structure; they are estranged places, places which are distinct, which though they actually exist - remain, in a way, outside all routinely accessible and experienceable places. In effect, such places, or living in them, create(s) a sense of crossing a certain boundary, of entering "a different world".

In this context the areas of post-Soviet bases in Poland deserve special attention because, ever since they came into existence, they have exhibited numerous features characteristic of "counter-sites". For the majority of inhabitants, military bases resembled inaccessible islands which, despite occupying concrete physical space, existed on the margin of the known world, and were governed by their own rules. However, these places prospered, concentrating the tools of military power and more often than not becoming local centers of economic networks. Although the process of ecological degradation progressed, in the social imagination the areas of the bases were not perceived as "degraded" landscapes, for political reasons, which inhibited public debate, and because of a lack of access and actual knowledge about what was happening within their limits. Thus, while before 1993 the process of degradation was shrouded in mystery and restricted to particular aspects (especially ecological ones), the public (re)construction of "degraded" landscapes started after the withdrawal of Russian Federation troops from the bases. In spite of appearances, the process of creating and making known the "degraded" landscapes ought not to be limited only to the activities of NGF SA soldiers.

\section{POST-SOVIET BASES IN POLAND: RUSSIAN LEGACY}

Although the withdrawal of the NGF SA troops from Poland ended in 1993, the first serious movements of the armed forces began as early as the late 1980s, even before the official negotiations (Krogulski 2001: 169). On May 22, 1992, the Polish and Russian governments signed a package of agreements related to the withdrawal of Russian Federation soldiers from Poland. ${ }^{13}$ The "zero option" was adopted. It consisted of a mutual renunciation of property rights and financial claims, and ultimately ended all existing agreements with Russia. 
From the financial point of view, adopting the "zero option" was not beneficial for Poland as it meant that the state would have to pay for all ecological and material losses caused by the NGF SA troops throughout the period of their being stationed in Poland. On the other hand, it was the only chance for an earlier withdrawal of Russian units from Poland, because otherwise their evacuation would have only started after the withdrawal of the Western Group of Soviet Forces from Germany. In total, the losses incurred by Poland due to the stationing of Soviet/Russian military troops were estimated at 62.8 billion PLN (according to 1993 prices), out of which the "zero option" accounted for 62.3 billion PLN (Zdzisław Ostrowski, quoted by Krogulski 2001: 188). The total costs of the ecological damage in the territory of all post-Soviet bases in Poland were estimated at 52.2 billion PLN (according to 1994 prices), and in the territory of the Borne Sulinowo training area itself at four billion PLN (Krogulski 2001: 184; Pomysł na Borne 1994).

As far as taking over the mienie pojarowskie (the property left by the Russian Army units), Poland adopted a decentralized system: all of the property, as the property of the State Treasury, was immediately handed over to the respective province governors, who from then on were fully in charge of the development process. ${ }^{14}$ Apart from financial problems related to the transfer of the property to its new owners, there were initially no laws regulating this process. The relevant law on the redevelopment of real property of the State Treasury regained from Russian Federation military forces was only adopted on June 10, 1994, with later amendments. The Council of Ministers established a multi-annual program entitled "Redevelopment of recovered property and areas degraded by military troops of the Russian Federation". The program assumed that in the years 2001-2007 the state budget would provide grants from the special budget reserve to local governments and other entities in order to speed up damage liquidation and finalize redevelopment of the property taken over from the Russian Federation military troops. Borne Sulinowo was one of the municipalities that benefited from this program. Although some additional sources of financing were also found (e.g. European programs), to date (2016) the areas of the former military bases have not yet been fully redeveloped and reclaimed.

\section{“DEGRADED” LANDSCAPE OF BORNE SULINOWO: OUTSIDE VIEW}

When one reaches Borne Sulinowo, located among forests, away from other settlements, one has an impression of having crossed an invisible border. Although at first glance the town appears ordinary, after a short while the 
increasingly distinct shapes of uninhabited houses, dilapidated buildings, squares leveled to the ground and bearing traces of the recent presence of something more, and knife-like spikes of broken windowpanes bent into some pattern of a structure-striving organization, begin to give rise to anxiety and prompt questions (Figs. 2 and 3). Such sensations intensify upon arrival in nearby Kłomino (Gródek), whose scattered remnants do not induce any hope for the future (Fig. 4). ${ }^{15}$

However, in the early 1990s Borne Sulinowo looked completely different than at present. Surrounded on all sides by a high wall (which was later demolished almost entirely), it was rough and gray, as befits a former military garrison. After the withdrawal of Russian Federation soldiers from Borne Sulinowo in October 1992, Polish Army (PA) units were installed there for several months. ${ }^{16}$ Their goal was to protect the property from looters and vandals. At that time, the area of the garrison was only accessible on presentation of special passes. After the transitional period, Polish soldiers left the former Soviet base and the garrison was transformed into a civilian town, whose official opening took place in June 1993. PA soldiers also protected the property left over in Kłomino, a small settlement formerly housing Soviet/Russian military forces, located twelve kilometers away from Borne Sulinowo (Gródek bez żołnierzy 1993). ${ }^{17}$ Apparently, the presence of Polish soldiers in Borne Sulinowo failed in its purpose, as in September 1993, during the discussion on the issue of redevelopment of

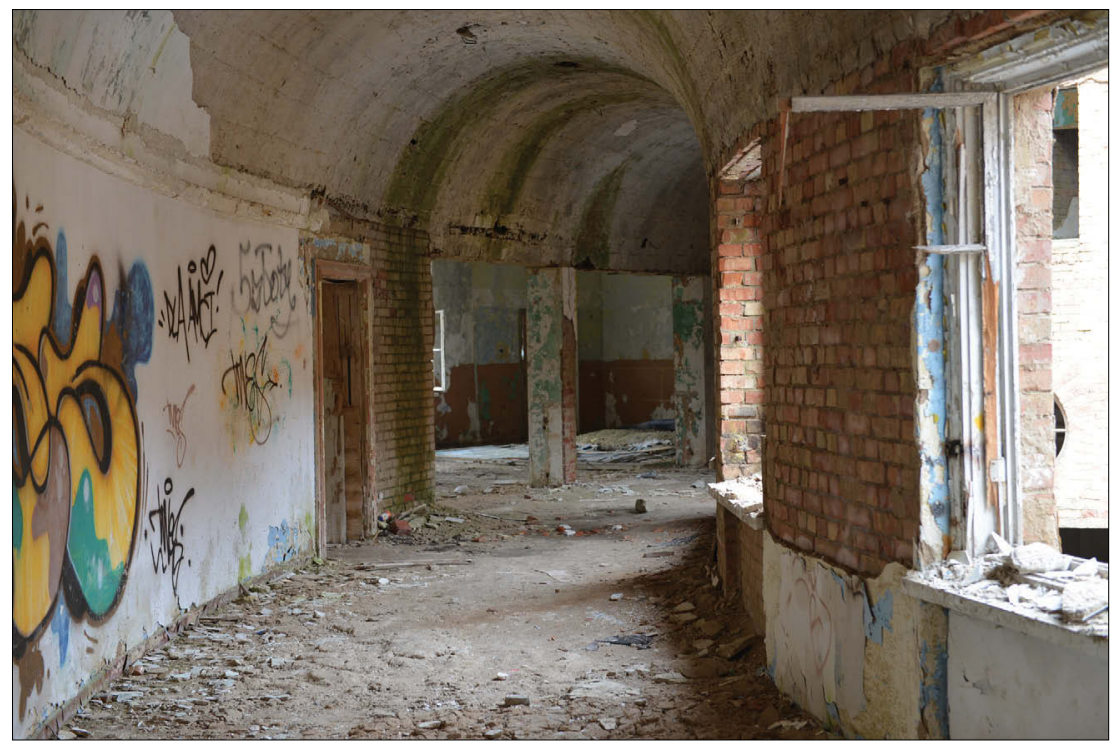

Figure 2. Degraded landscape in Borne Sulinowo. Photograph by Dominika Czarnecka 2015. 


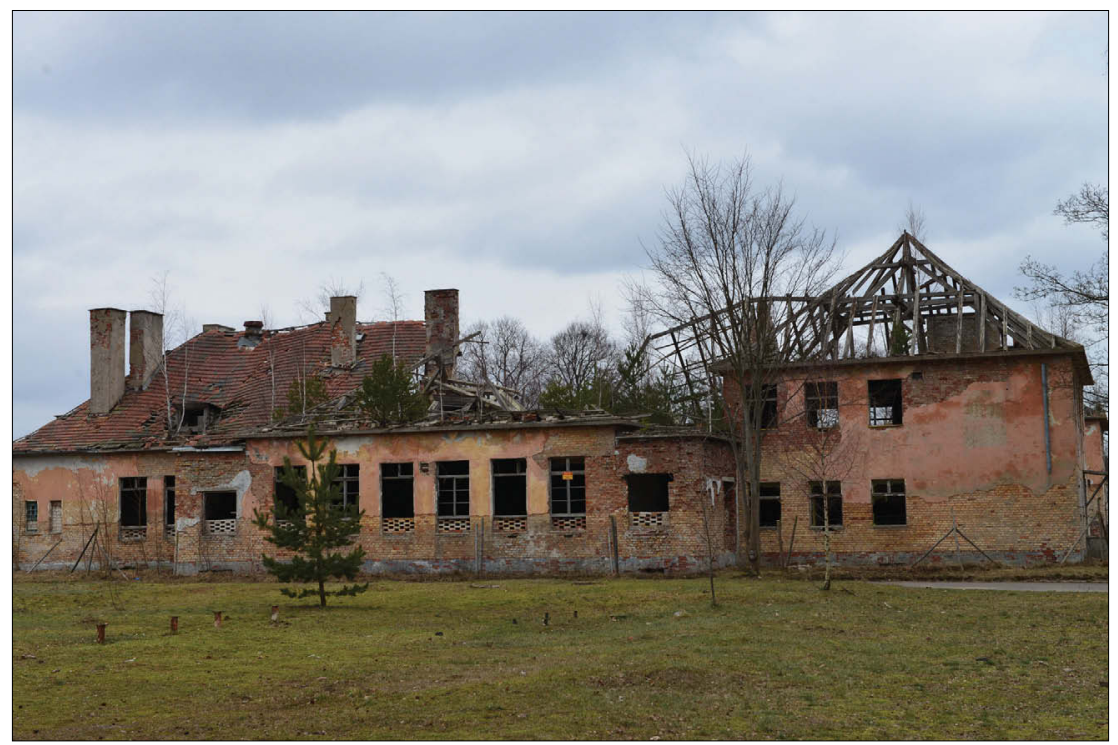

Figure 3. Degraded landscape in Borne Sulinowo. Photograph by Dominika Czarnecka 2015.

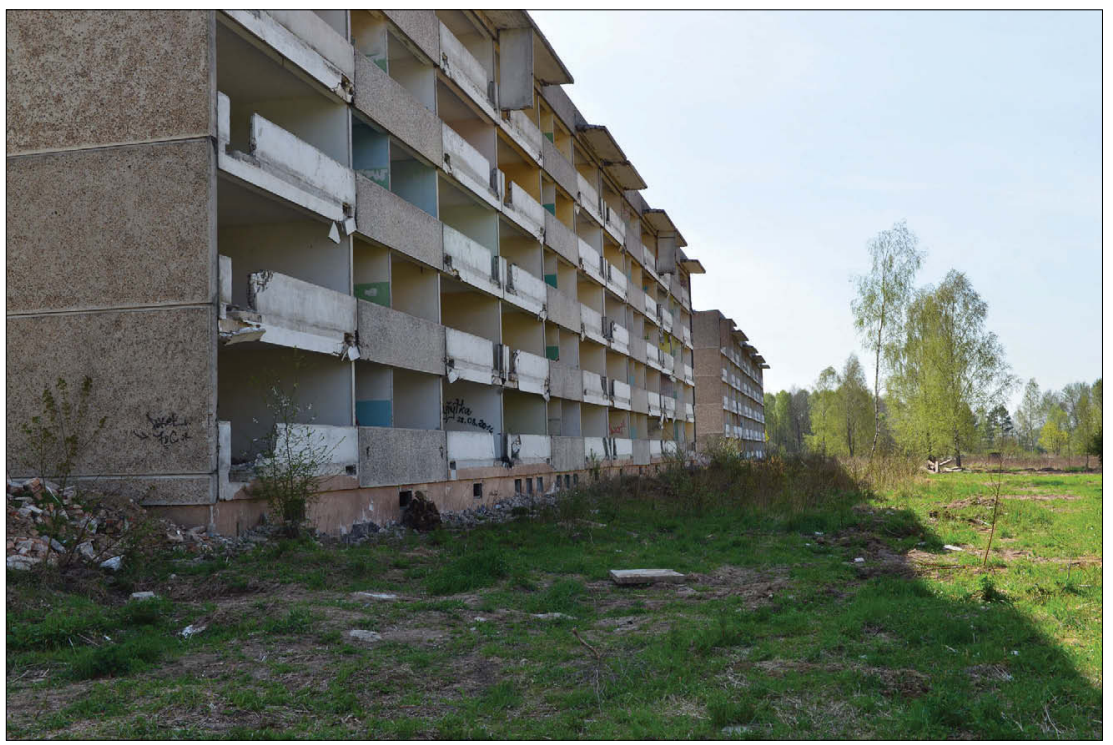

Figure 4. Kłomino. Photograph by Dominika Czarnecka 2015.

Kłomino, where "the Russians left several residential blocks and the devastated garrison buildings" (Sztyler 1994: 15), it was mentioned that effective measures were needed "to prevent damage and theft of property which, unfortunately, had been taking place in Borne Sulinowo" (Gródek do wzięcia 1993). 
In January 1994, Moreny republished a feature (translated into Polish) by Los Angeles Times journalists who had visited Borne Sulinowo in 1993. The descriptions they compiled represented the outside view. The article showed the former military base as "the land of chaos and great opportunity, where the security carries loaded guns and the residents enjoy their spare time in a bar named 'TEMPTATION'. ... Borne Sulinowo used to be considered the busiest base in Eastern Europe. ... But when the Russians left a year ago, the area of 70,000 square kilometers that constituted Borne Sulinowo was in ruins... What is worse, Russian soldiers robbed the base of everything that represented any value - from toilet bowls to telephone cables and commemorative tombstones. Whatever they left was looted by gangs of thieves who were stealing radiators, bathtubs and doorframes by the truckloads. Now, homesteads that were locked or hastily bricked up are guarded by the security carrying guns tucked into their belts..." (Murphy 1994: 4).

Although the article described a wave of pioneers flowing in from all over Poland and their endeavors to begin new lives in Borne, in reference to the base it contained such phrases as "grown wild after the Soviet Army had left", or "management of the ruined property" (ibid.). Moreny also republished articles from nation-wide newspapers, which contained descriptions related to the former base and Soviet/Russian soldiers. For instance, a journalist from the Nie weekly said:

Departing into the unknown eastern future, the Soviet soldiers palmed off to local peasantry all that could have been taken away, carried out, poured off. It started with the fuels and only the empty containers were left ... Then it was the turn for radiators, floorboards, water closets, bathroom tiles, and even doorknobs. (Pisali o nas 1995)

On the other hand, Gazeta Polska wrote:

The locals know all the forest paths. They took them to go trade with the Russians. ... We made do. When they went away, we went to take what was left behind. It belongs to us, not to those new settlers. An inheritance, so to speak. (ibid.)

As far as the ecological condition of the base is concerned, in the Soviet military period it remained entirely unknown to the Polish administration. This is why immediately after the withdrawal of foreign troops from Borne Sulinowo, agencies of the Polish administration ordered essential measurements related to the state of the natural environment to be conducted. The research was led by, among others, a group of Polish experts from the Wojskowa Akademia Techniczna (WAT) ('Military University of Technology'), together with a group of German specialists from Dortmund, acting within the framework of one of the 
ecological commissions of the Council of Europe. WAT's final report indicated that the town was free from pollution and contamination (Rząd 1994). The norms for acceptable pollution/contamination were exceeded, however, near fuel depots, chemical training grounds, chemical warehousing facilities and waste storage facilities (Sa czy 1993). ${ }^{18}$ The ecological condition was one of the basic determinants of introducing civilian settlement in the area of the base. The press reported "increasingly better, fantastic even, results of the tests. The place started to be compared with the cleanest regions of Europe" (Rozgoryczenie 1994). Thanks to the satisfactory results of the tests, in Borne Sulinowo the idea was conceived to create "green schools" for children from ecologically endangered areas. According to the statements issued then by the local authorities, the endeavor was to become a driving force for the future development of the town (Szpindor 1992: 5). Ultimately, the idea was not put into practice. Although there were at least several reasons for that, in the context of the present analysis it is worth mentioning the change in the supra-local narratives.

Despite the fact that as soon as the end of 1993 the media started to mention possible contamination with increasing frequency, the real change came with the report compiled by the chief inspector of environmental protection in 1994, entitled "Identification and evaluation of ecological damage caused by Russian Federation Forces stationed in Poland" (the report contained descriptions of all of the post-Soviet military bases) (Kamieński et al. 1994). On the basis of this report, it was announced that decontamination of the destroyed areas "will take... several dozen, or even - in certain cases - several hundred years" (Borne w dokumentach 1995; Koszty przyjaźni 1993). The most polluted places mentioned in the report were Brzeg Opolski and Borne Sulinowo. The data contained in the report was quickly widely publicized by the national Polish media. Journalists started to inform the public about all possible and imagined types of contamination, infection, and pollution. In April 1994, Polish Television and newspapers, such as Gazeta Wyborcza (national) and Trybuna Śląska (regional), spread information about the "Lost Land" (Ekologia 1994). After a press conference of the chief inspector of environmental protection, Andrzej Walewski, Gazeta Wyborcza wrote that in Borne Sulinowo "an underground river of oil and chemical waste is flowing towards the lake" (Karkoszka 1994: 8) and published a "death map", which was later republished by other media. Such expressions as "death zone", "lost land", and "Little Kuwait" started to circulate. However, pieces of information published by the media were inconsistent, often contradictory. Numerous journalists, some of whom had never been to Borne Sulinowo, wrote such reports to cause sensation, attempting to join in the antiRussian discourse on a supra-local level (see Czarnecka 2015: 21-40). The Board of Green Schools Foundation (a supra-local body) announced in relation to the report of the chief inspector of environmental protection: 
Even if the data contained in it prove imprecise after more in-depth analyses and studies, this will not change the fact that Borne Sulinowo will be associated with a death zone, a place to which no parent would send their child to a green school. Therefore, this report is a final blow to those operations of the Foundation which were to lead to creating such a center. (Rozgoryczenie 1994)

Apart from the information on chemical contamination, in the early 1990s the media often made references to radioactivity and unexploded ordnance. As far as radioactivity is concerned, no research confirmed such a threat. Meanwhile, the press repeated gossip about fluorescent mushrooms and dying fish, which was highly evocative, especially in the context of the relatively recent Chernobyl nuclear reactor accident (1986) and the images of the deserted, ecologically degraded Ukrainian town of Pripyat. The following excerpt provides a relevant example:

Allegedly, in the woodlands of the training ground there is a 'death zone', where no civilians have ventured for years. In the early $1980 \mathrm{~s}$ a scrupulously concealed 'accident' took place there and that is why some of the contamination in this region is supposedly radioactive. (Ktokolwiek wie 1994)

The local population treated such revelations as an attempt to sensationalize, which was expressed in the local press:

Radioactive scam. No one in Borne Sulinowo is afraid of either radioactive or chemical pollution. 'I don't know where the gossip on Borne's contamination comes from. I heard those stories about the lake polluted with phenol and about people whose hair fell out after a visit to Borne. But this is not true', the parish priest explains. The others, asked if they are not afraid to live there, tap the side of their heads or grumble about the press which has, until recently, written at length about the radioactive pollution in Borne. (Łazarewicz 1993: 4)

The problem of unexploded ordnance and the costs of land re-cultivation were also frequently discussed. One of the 1993 press articles contained a commentary related to the military training grounds in Borne Sulinowo:

We [a journalist from the supra-local newspaper and foresters - D.C.] reached this place through devastated forests, full of trees broken by shells and evidence of fires which happened several times a year. The Russians did not always allow our firefighters and foresters to conduct firefighting and rescue actions. (Karkoszka 1993: 5) 
At the same time, apart from information related to the threat of unexploded ordnance and clearance operations, ${ }^{19}$ the article mentioned the process of reforestation and the costs of re-cultivation operations, amounting to an average of 11.5 million PLN per hectare. A member of the National Forests staff told the newspaper:

We are planting pines, oaks, and birches. This land had been waiting for that for dozens of years. So far, the seedlings have grown like crazy. There, look at how green it has already become, and only two years ago there was only sand there. Plants, animals, and birds are coming back. (ibid.)

Newspaper Stowo Polskie wrote that the Soviet/Russian military forces were not held responsible "for instance, for ecological losses which they caused on the territory of our country. ... It will take time before nature will effectively help us heal these wounds; it will also take time before man can accomplish something here" (Pisali o nas 1995).

The Soviets/Russians were named as those who had caused the ecological damage, which was quite true, yet it was also stated that, as a result of the "zero option", it was impossible to force the Russians to finance any of the recultivation of the natural environment.

Meanwhile, there is no doubt that the withdrawal of the Russian Federation soldiers from Borne Sulinowo and the perception of the landscape as degraded influenced the attitudes and actions of people who arrived in Borne Sulinowo with no intention of settling in the town. Especially during the first stage, they plundered and destroyed items left by the Soviet/Russian soldiers. However, the ecological degradation of the post-Soviet base was not increased (e.g. no illegal garbage dumps were found), which was certainly influenced by the quite quick process of settlement in this territory and efforts of local governments.

The majority of Borne Sulinowo inhabitants did not believe the revelations published by journalists from the supra-local media, a fact which is shown, for instance, by the low percentage of residents who left the town. However, on the local level it became noticeable that such commentaries had negative effects on the development of the town, which was only beginning to organize itself. The inhabitants of Borne Sulinowo issued an official protest to the authorities of the province (List otwarty 1994). In order to placate them, a meeting with the provincial environmental protection inspector was arranged in the town. With regard to the 1994 report, it was stated that the differences in the assessments of the situation were probably caused by changes in research methodology and contamination limits (which were made stricter) (Małolepszy 1995: 8-9). 


\section{"DEGRADED" LANDSCAPE OF BORNE SULINOWO: NATURAL ENVIRONMENT. INSIDE VIEW I}

The interviews I conducted with the inhabitants of Borne Sulinowo in 2015 and 2016 on the subject of the degradation of the post-Soviet base and the personal attitudes of the settlers towards what happened there in the early 1990s reveal a slightly different picture of the reality of the time than the one presented on the supra-local level. Yet, it is worth noting that the interviews were conducted over twenty years after those events had taken place. In fact, it is necessary to remember that past decisions, opinions, and attitudes of Borne Sulinowo inhabitants find additional support in the fact that throughout the period of the civilian town's functioning no ecological disaster has taken place, there have been no serious incidents of contamination or diseases, and the town has become one of the best known and fastest developing post-Soviet settlements in Poland.

The majority of people who decided to come to Borne Sulinowo at the beginning of the 1990s were mostly driven by housing-related considerations (similar houses or flats in other regions of Poland, if available, cost at least two or three times more at that time), together with an opportunity "to start everything anew". As a rule, new settlers had no knowledge of the former military base because even those who came from the surrounding settlements did not have access to the garrison town in the period when the Soviet/Russian forces were stationed there (apart from a small number of specialists). In this sense, all of them entered an unknown region.

As far as environmental degradation is concerned, the majority of the newcomers did not worry that the area of the former military base presented a risk to life or limb, having assumed that since the representatives of state governments decided to establish a civilian town and encouraged its settlement, experts must have conducted the necessary measurements and that it was safe there. There were some whose experience suggested that some threats might be present in a post-military area, but they accepted this possibility and took the risk in the name of new opportunities:

I realized that after forty-seven years of military presence here all kinds of surprises might come up related to unexploded ordnance, maybe some ground contamination. ... I was aware of that. ... You know, I wished to do things my own way... ${ }^{20}$

On the local level, reactions to the subject of contamination varied. Some "people were simply afraid, it was natural, nothing surprising about it", ${ }^{21}$ yet only in a few cases did this fear lead to leaving the town. Among those who stayed in Borne Sulinowo, various strategies were employed. Some did not believe the 
information which appeared in the mass media, claiming that journalists were only sensationalizing. Some were not interested in matters which remained outside their everyday existence. Others trusted the decisions made by the representatives of state agencies: "I simply have faith in those who rule here.... If it is possible to live here, they must know it is possible...", ${ }^{22}$ their own direct experience (e.g. observation of plant and animal life) contradicted media revelations, or they found information in sources they considered more credible:

[A]t that time the authorities and the military assured us that there was nothing here that would endanger our lives... I also had an opportunity to meet officers of the former Russian Federation... and they also claimed... that 'we lived in the town with our families and we wouldn't allow our own families to be poisoned'. And this is convincing. ${ }^{23}$

Media reports circulated on the supra-local level had negative consequences for the development of the local community, for instance, in the context of the development of tourism, which formed one of the basic income sources for Borne's inhabitants. There was difficulty in gaining new investors. One of the inhabitants of Borne Sulinowo stated:

[T]he press did not favor us, when you think of those first years of development of Borne Sulinowo, and neither did the rest of the media, and it is those all-Poland media that very much disfavored us. I don't know why. ... Of course, we tried to present Borne Sulinowo in the best possible light, its 'tourist potential'... We were always shown as a former military base, a contaminated, degraded place. And since then we have been just a little prejudiced towards the media...24

As it later turned out, some information related to environmental pollution (e.g. contamination of Lake Pile waters with phenol and mercury) was purposefully made up by competitors in the tourism and recreation sector, since Borne Sulinowo, surrounded by forests and lakes, had quickly built up its position as a tourist attraction of the region (Potwór 1994).

It is also worth mentioning that even now at least some inhabitants of Borne Sulinowo are afraid that when the Russian Federation soldiers were withdrawing from Poland, they might have hidden somewhere on the base something that would be hazardous and difficult to handle (e.g. chemical weaponry). Foreign soldiers could have poured concrete over such waste somewhere underground, which would make it a ticking time bomb. As these types of scenarios remain mere suspicions, they say more about the attitude of the Poles to Soviet/Russian soldiers than about the actual state of affairs. 
Summing up this sub-chapter, it is worth noting three points. Firstly, the inhabitants of Borne Sulinowo believed that although NGF SA soldiers living there did not respect the natural environment, they did not degrade it consistently or with determination. Secondly, the settlers were in agreement as to the fact that Soviet/Russian soldiers were responsible for ecological damage on the former base. And finally, the inhabitants did not agree to the image of the former military base, constructed on the supra-local level, as an ecologically degraded place.

\section{“DEGRADED” LANDSCAPE OF BORNE SULINOWO: BUILT ENVIRONMENT. INSIDE VIEW II}

In the early 1990s, Borne Sulinowo looked different than at present. The local press repeatedly published the memories of the first inhabitants of Borne Sulinowo, which painted a picture of the youngest Polish town of the time:

It was a strange town, completely different from what it is now. Empty, alien and menacing! ... Empty houses, windows boarded up and padlocked doors, a haunting sight... Broken furniture, suitcases, containers left by the Russians scattered around the buildings. Abandoned, ravenous dogs and feral cats were wandering among the deserted blocks of flats. And something 'ever-present' - the stench, that horrible stench! ... Sleeplessness intensified by thuds of doors being pulled out of their frames and padlocks torn off. Thieves didn't sleep that night either, and not just that night! Municipal workers could hardly keep up with installing new padlocks... And the soldiers? They sat in their guardhouses... (Poczobutt 2003: 28-29)

What is significant is that descriptions of this sort did not concern the state of the base right after the withdrawal of the Russian soldiers - a fact rarely noted. They were usually related to the stage after the end of the transitional period, when the garrison was already under the supervision of the Polish Army. According to the substance of the interviews conducted with people who arrived in Borne before the town was officially opened, despite the concerns of the Polish authorities the foreign soldiers devastated neither the structures in a way that could limit the town's functioning (e.g. the main boiler plant, water treatment plant or ester supply system) nor the remaining buildings (they closed off numerous buildings before they left). In the opinion of many inhabitants of the post-Soviet base, most of the damage in Borne Sulinowo was done by Poles themselves: 
It's not true that the Russians destroyed [everything]; the Poles did. I used to live in Kragi ${ }^{25}$ and the Poles carried away various things using tractors. ... I'm not saying that they were from Kragi only, [but] from the whole municipal area. ${ }^{26}$

There were hordes of thieves here, who devastated the town; all metal elements were torn out. The municipal government, so as to rescue at least something, had the heaters taken out... ${ }^{27}$

One of the settlers, a specialist who was present on the base when the Russian Federation troops were leaving it, claimed that in the final phase several soldiers who did not want to leave Poland tried to hide on the base. A search began and possessions were thrown out of the windows of the searched flats:

Then, when they were showing Borne on TV, there was always this pile of broken furniture in front of and next to the buildings, because there were three buildings there, and there was this whole row of furniture somewhere up to above the first floor. ... And another site was the junkyard, a couple of hectares of it. And always, if it was about Borne, then there was this junkyard and this broken furniture. Such was the image of Borne then. ${ }^{28}$

Therefore, although the Soviets/Russians constructed on the site of the base many objects which did not meet the required norms of the Polish construction law (later it was necessary to reconstruct or demolish them, which in both cases required substantial financing), and the road infrastructure was in terrible condition as a result of heavy vehicle traffic, in the opinion of the majority of the first settlers, the degradation of the built environment of the former Soviet base was mostly the fault of Poles. This does not in any way alter the fact that damages inflicted by the armed forces stationed there, together with the failure to observe the norms and standards applicable in Poland by NGF SA soldiers, led to lowering the value (including economic) of the property of the base, and to changes in its landscape. The property, which was left unattended and without adequate funding after the withdrawal of the Russian Federation forces, was either devastated by vandals or gradually fell into ruin, additionally decreasing the value. As a result, the process of degradation continued. One of the most dramatic examples of this process is Kłomino, where degradation affected the whole area of the settlement (Sztyler 1995: 12-13). 


\section{STRATEGIES OF PRESENTING SOVIET/RUSSIAN SOLDIERS IN THE CONTEXT OF THE PROCESS OF "DEGRADATION"}

At the onset of the 1990s, the condition of various levels of political, administrative, and economic structures in Poland (the bare bones of the main structure are made up of little sub-structures, e.g. post-Soviet bases) may be described as being in transition. In such a stage all attributions of danger and power are manifested much more distinctly than in normal circumstances. Activities related directly or indirectly to "degraded" landscapes on the former Soviet/ Russian bases reflected the process of revision of the norms, relations, functions, and boundaries within the main structure. Although individual levels of a structure may differ from one another, it is worth noting that they never remain completely isolated, but overlap and supplement one another.

Various strategies of presenting Soviet/Russian soldiers were used in the narratives on Borne Sulinowo (both on the supra-local and local levels). The soldiers could be presented as "main characters of the story" or as agents of certain activities that shaped the degraded landscape of the post-Soviet bases. In the latter case, alien soldiers were presented indirectly (through descriptions of the base), which does not mean that the descriptions were less effective.

As a rule, Soviet/Russian soldiers were shown as responsible for ecological damage, and therefore as having undertaken actions that destroyed the natural environment or blocking initiatives which could have prevented the negative effects of such degradation. Their agency was connected with an essential lack of responsibility (as a rule, emphasis was placed on financial responsibility) for the damages caused in a foreign, though "allied", country.

On the supra-local level, the message was at least partly directed at creating the sense of ecological disaster on the former military bases. Exposing pollution and contamination, issues which were juxtaposed with descriptions of rehabilitation work after Soviet/Russian soldiers' withdrawal from Poland, served to create "us"-"them" contrasts. While "they" were presented as undemocratic, exploitative, irresponsible, and so on, "we" appeared as co-operative, productive, and responsible guardians of land and natural landscape. In the context of contamination, foreign soldiers were presented as those who disturbed a certain order, as a source of chaos and problems, and this, in turn, was related to articulate and inarticulate powers vested in them. This was by no means an exclusively internal order, but global and universal, if we assume that natural landscape is heritage for future generations and that natural environment is humankind's resource (Milton 1996: 173).

As Mary Douglas aptly noted, disorder - just like formlessness - is destructive to existing patterns: "It symbolizes both danger and power" (2001 [1966]: 
95). Contamination is characterized by a lack of form, often intensified by its invisibility, as in the case of radioactive contamination. Pollution is a particular class of danger; yet, in order to perceive the significance of a specific threat in the context of a given community, it is necessary to place this threat within the whole range of dangers possible in any given universe, because "Some dangers are great and others small" (ibid.: 4). In the Western European context, environmental pollution, especially radioactive pollution, ranks high in the hierarchy of possible threats, and exists in a close relationship with dangerous power. Currently, the risk of an ecological disaster forms a recurrent motif of everyday life (Giddens 2010: 15).

The presentation of Soviet/Russian soldiers as a source of disorder was also related to opinions about the ways in which foreign soldiers treated movable and real property. In this respect, representations of Soviet/Russian soldiers were negative and one-dimensional, while the part played by Polish vandals and looters in the process of the devastation of the base was passed over or marginalized. Thus, both in the ecological context and from the point of view of lowering the economic value of the base's property, alien soldiers were seen as the degrading side. Presenting the base as a place grown wild and ruined reinforced the stereotypes and the images of Soviets/Russians as "barbarians from the East", who were a source of menace and destruction due to their power (in this case, military), and who treated the area of the Polish base as war plunder.

The strategies of presenting Soviet/Russian soldiers were different on the local level. Inhabitants of Borne Sulinowo, who were beginning new lives on the post-Soviet base and observed their surroundings daily, treated ecological issues in practical terms (a challenge that needed to be confronted). Although in the bottom-up narratives of the civilians there were accounts and recollections connected with illegal and environmentally abusive activities of ordinary soldiers (e.g. trade in fuel and blast fishing), the inhabitants of Borne Sulinowo saw the greatest threat as lying in the functioning of the Soviet Army, whose negative image they additionally stressed by juxtaposing it with the functioning of NATO forces. It cannot be excluded that the more moderate opinions toward the illegal activities of Soviet/Russian soldiers were caused by the fact that some inhabitants of Borne Sulinowo, born in the surrounding settlements, benefited economically from such practices.

With respect to the property left on the base (and its degradation), their judgments were also more varied and ambivalent, which is not to say that they were positive. Whereas the stress placed on the difficulties related to the process of settling the former garrison was a way of presenting the organizational difficulties with which new settlers had to deal, presenting the base as a degraded landscape was absolutely against the interests of the newly forming commu- 
nity. Thus, the representations of the base constructed top-down were received negatively on the local level, as they were in conflict with the bottom-up view.

It is difficult to resist the impression that the outside view was aimed at other ends than the image seen and presented on the local level. It was also directed at, and reached, if not a completely different audience, at least a much wider one. It is on that level that we can observe the influence of the third meaning of the word "degraded": its symbolic dimension. Within the strategy of presenting Soviet/Russian soldiers in the context of the landscape of a "degraded" post-Soviet base, employed on a supra-local level, a shift between the degraded and the degrading sides took place. This is because presenting the results of the activities of foreign soldiers (the degrading side) served to degrade them symbolically. Alien soldiers were placed in the role of the degraded side, whose status in the new context was altered or, more specifically, lowered. Depriving "Others" of their former position was a way of diverting a threat and securing the functioning of an ordered structure, but it also reflects changes in power relations. ${ }^{29}$

\section{“DEGRADED” LANDSCAPE: ACTUAL STATE OR A WAY OF SEEING?}

Although at the onset of the 1990s nearly all post-Soviet bases in Poland were presented on the supra-local level as degraded and ruined landscapes grown wild, after more than twenty years, since the final withdrawal of Russian Federation forces from Poland, it is possible to notice that time treated some places mercilessly, while others were spared. Borne Sulinowo used the change to its advantage and, despite having initially functioned with the stigma of a "degraded" place, it underwent a reorganization which led to discovering new resources, including settlement in new networks and changing its own status. Helpless Kłomino, on the other hand, remains an embarrassing reflection of a "forest town", embodying the chaos of a battleground and transforming its former status of "counter-site" into an extreme shape. Borne and Kłomino reflect the interplay of ideas of form/order and formlessness/disorder. Yet, even today there are ruins, uninhabited houses and the stigma of everyday uselessness in Borne Sulinowo.

John Berger claimed that "the way in which we perceive things depends on our knowledge or faith" (2008: 8), and that "looking is an act of choice" (ibid.). "Degraded" landscapes may be treated as more than just actual reality. They may be treated as specific ways of seeing, different depending on who is looking, what is paid attention to, and what goal is related to this act. The case of 
Borne Sulinowo makes it possible to notice that the basic differences in seeing resulted from the levels on which particular narratives were constructed: local vs. supra-local, outside vs. inside views. The point of view of a Borne Sulinowo inhabitant, who experienced the environment of the former base daily and in its entirety (e.g. the natural environment, the ruins, and other post-Soviet remnants) with all of the senses, was certainly different from the point of view of a central government politician or a national media journalist. The differences resulted not only from dissimilar interests and experiences, or different knowledge of the place, but also from Berger's concept of "faith". Equipped with that faith, new settlers did not perceive the Soviet base as a "degraded" landscape, but rather as a potential, an opportunity. It seems impossible to live and build on land which one personally perceives as "degraded". Such a way of seeing is a negation of the faith and hope indispensable for triggering agency.

From the supra-local perspective, presenting the post-military Soviet space as "degraded" was related to the process of symbolic conversion. After the change in status, after the marginalization and reduction of its value, a process of including that sub-structure in the main structure began, while viewing it as something different. Nicholas Mirzoeff remarked that "visual culture is a set of relations between what is visible and the names which we give to what is seen" (2016: 25). Ecological degradation may also be perceived as a specific way of seeing, manifesting itself in the form of diversified and changeable norms and methods of pollution measurement. Examples illustrating this multidimensionality, but also the perfidiousness of seeing in this particular case, were the changes in the interpretation of ecological conditions of Borne Sulinowo caused by the publication of the report of the chief inspector of environmental protection in 1994.

Ruins, meanwhile, are not an invariable and unquestionable indicator of an ongoing process of degradation. They involve a way of seeing that determines whether a dilapidated building will represent to its viewer the quintessence of a fall or an object of fascination related to the "ruin gaze" ${ }^{30}$ From this perspective, the inside view and the outside view are supplemented by the "romantic" view of tourists and other outside visitors who seek aesthetic qualities and thrills in "degraded" landscape. For people who arrive in Borne Sulinowo and participate in such activities as paintball, treasure hunts or the International Rally of Military Vehicles, seeing the post-Soviet base as a ruined place is attractive (in contrast to the general outside view). Interviews with inhabitants of Borne Sulinowo revealed the dilemma of whether to live in a more aesthetic, renovated, and modern built environment or to preserve the original features of the military garrison. The ruins and the atmosphere of mystery created by them are an important tourist attraction in the region, which is a source of income 
for at least some local settlers. Therefore, the attitude of the local community to ruins and other post-Soviet remnants is diversified, based on the role they play in the process of achieving personal aims.

If we assume that degradation is a way of seeing (at least to a certain extent), then "degraded" landscapes become forms which are relative, changeable over time, and culturally constructed.

After the final withdrawal of the Russian Federation soldiers from Poland, dozens of "degraded" landscapes (which until the early 1990s were invisible both literally and metaphorically) suddenly appeared. In the context of the above reflections, the question arises as to the extent to which their status represented actual reality or was a way of seeing, a cultural construct written into the sociopolitical context of the time, a need to react to over forty years of foreign troops' presence in Poland, stereotypes related to Soviets/Russians or, finally, the extent to which the "degraded" landscape reflected the relationship between Soviet/Russian armed forces' legacy and ourselves. Both the outside and the inside views were adopted standpoints and specific ways of understanding the world, while "degraded" landscapes constructed on the supra-local level formed integral building material of the reality of the time, appearing as repeated structures connected with organizing the community under new principles. Finally, in the early 1990s, the "degraded" landscapes of the former military bases in Poland fulfilled specific tasks on at least two levels: the more obvious one was largely instrumental and the other one was expressive.

\section{NOTES}

1 When I use the term "Soviet soldiers", I refer to the soldiers of the Northern Group of Forces of the Soviet Army (NGF SA) (1945-1992). When I use the term "Russian soldiers", I refer to the soldiers of the Russian Army (1992 till now). When I refer to the whole period of the stationing of foreign forces in Poland, I use "Soviet/Russian soldiers".

2 Deputy Prime Minister and Minister of Finance in Tadeusz Mazowiecki's government in 1989-1991.

3 The data quoted by Mariusz Lesław Krogulski came from the progress report of the working group for the cost analysis of Soviet military forces stationed in Poland, dated March 30, 1990.

${ }^{4}$ I have described the history of the military base in Borne Sulinowo in more detail in earlier publications. These papers are related to the subject matter with which the present analysis is concerned; in fact, they complement one another. Wishing, on the one hand, to avoid unnecessary repetition, but on the other hand aspiring to cohesion and clarity of the following part of the argument, I have indicated in the text the issues which were described in the previous publications only when necessary. 
5 I have put the adjective "degraded" in quotes when it is used in the word's multidimensionality. Otherwise, I have used the normal notation.

6 I carried out my research in Borne Sulinowo in February, May, and August 2015, and in May 2016. I conducted nearly thirty in-depth interviews with the town's inhabitants (the "snowball technique" was used to find new respondents). I used the method of participatory observation and performed a search of local press and source materials collected in the private archives of the manager of the Museum Chamber in Borne Sulinowo.

7 As a local newspaper, Moreny employed journalists from Borne Sulinowo and its surroundings. I have treated their viewpoint, together with that of the accounts of the town's inhabitants (e.g. protests, letters, and commentaries) as elements of the inside view. Additionally, Moreny often republished articles from national and regional press, related to Borne Sulinowo and its vicinity, or to other post-Soviet bases. These resources have been treated as elements of the outside view.

8 As a result of the Potsdam Conference agreements of 1945, the borders of the Polish state were altered. Poland gained territories in the west from Germany, later colloquially called the "Recovered Territories"; in the East, however, it lost lands to the USSR, which formed over half of the pre-war territory of Poland.

9 "Polish October" is also known as the "Polish October Revolution" or "October 1956". After several demonstrations and tense negotiations, the Soviets gave permission for Władysław Gomułka (the leader of the reform faction in the Polish United Workers' Party) to stay in control, and made several other concessions resulting in greater autonomy for the Polish government. This marked the end of the era of Stalinization in Poland.

10 The Soviet military garrisons in Poland: 1. Przemków, 2. Duninów, 3. Chocianów, 4. Chojnów, 5. Strachów, 6. Nowa Sól, 7. Szprotawa, 8. Krzywa, 9. Trzebień, 10. Żagań, 11. Jankowa Żagańska, 12. Świętoszów, 13. Lubin, 14. Raszówka, 15. Legnica, 16. Jawor, 17. Strzegom, 18. Świdnica, 19. Wrocław, 20. Oława, 21. Brzeg, 22. Opole, 23. Lądek Zdrój, 24. Świnoujście, 25. Szczecin, 26. Chojna, 27. Wędrzyn, 28. Kęszyca, 29. Kluczewo, 30. Bagicz, 31. Białogard, 32. Szczecinek, 33. Krągi, 34. Borne Sulinowo, 35. Sypniewo, 36. Września, 37. Toruń, 38. Łowicz, and 39. Rembertów.

${ }^{11}$ Brzeźnica is located approximately thirty kilometers to the south of Borne Sulinowo. Jointly, there used to be three nuclear weapon depots in the territory of Poland. The remaining two were located in Templewo, near Trzemeszno, and in Podborsk, near Białogard (Szulc \& Nicpoń 2007: 62-77).

12 The term "side" is used conventionally here to denote individuals and groups, as well as institutions.

${ }^{13}$ Executive decisions for the adopted provisions were prepared in June 1992.

${ }^{14}$ A different solution was adopted in Germany, the Czech Republic, and Hungary, where the whole property formerly belonging to the Russian Army was taken over by the Ministries of the State Treasury, and the ministries themselves initiated the process of seeking new users (Czulicki 2014: 21).

${ }^{15}$ Borne Sulinowo, Kłomino, and the extensive military training grounds located between them made up the whole huge complex of the Soviet/Russian military base. 
${ }^{16}$ In the period between the withdrawal of Russian Federation troops from Borne Sulinowo and the decision to establish it as a civilian town, Polish authorities considered the option of transforming it into a garrison of the Polish Army.

17 The situation in Gródek was even more difficult than in Borne Sulinowo, as this was a military settlement separated from larger urban centers and lacking basic infrastructure essential for turning it into a residential settlement.

18 The research of the scientists from WAT covered 59,900 of the 70,000 ha of the total area of territories occupied by Soviet/Russian soldiers (in twenty-one places where they were stationed). There were 406 ha of land recognized as regions of ecological disaster (noxious waste stores, floating fuels, and chemical contamination). The report stated that Soviet/Russian soldiers devastated 38,100 ha of forests, 6,500 ha of ground water, 17.5 ha of surface water aquifers, and 15,300 ha of soil and vegetal layer (Kamieński et al. 1994: 15, 24).

${ }^{19}$ Information regarding the action of clearing mines from the post-military areas appeared in the press numerous times in the following years (Chabior 1992: 2; Min nie ma 1993; Wybuchowe Borne 1995). The operation of clearing mines from the training grounds in Borne Sulinowo ended in 2015, and was an effect of the implementation by the State Forests National Forest Holding (SFN FH) of the project "Re-cultivation for natural conservation purposes of the degraded areas, former training grounds, and post-military areas remaining under SFN FH management".

${ }^{20}$ Interview with D. Sz., Borne Sulinowo, May 2016.

${ }^{21}$ Interview with D. Cz., Borne Sulinowo, May 2016.

${ }^{22}$ Interview with D. K., Borne Sulinowo, May 2016.

${ }^{23}$ Interview with J. M., Borne Sulinowo, May 2016.

${ }^{24}$ Interview with D. T., Borne Sulinowo, May 2016.

${ }^{25}$ A village situated in north-western Poland. It lies approximately four kilometers northeast of Borne Sulinowo.

${ }^{26}$ Interview with D. K., Borne Sulinowo, May 2015.

${ }^{27}$ Interview with P. K., Borne Sulinowo, May 2015.

${ }^{28}$ Ibid.

${ }^{29}$ After the end of World War II, the western territories incorporated into the Polish state, which earlier belonged to Germany, underwent a process of constructing alienation towards Germans. It was in no way related to a "degraded" landscape in the context of the former German bases taken over by the Red Army, and it proceeded differently. This issue is worthy of another study and does not form a part of the present analysis; however, it demonstrates that "degradation" is a cultural construct.

${ }^{30}$ The ruin gaze "can be understood as the particular optics that frames our relationship to ruins. Contemporary ruinophilia relates to the prospective dimension of nostalgia, the type of nostalgia that is reflective rather than restorative and dreams of the potential futures rather than imaginary pasts" (Boym 2011). 


\section{REFERENCES}

Berger, John 2008. Sposoby Widzenia. [Ways of Seeing.] Warszawa: Fundacja Aletheia. Borne w dokumentach 1995 = Borne w dokumentach. [Borne in Documents.] Moreny: Gazeta Krainy Jezior i Lasów, No. 16, pp. 7-11.

Boym, Svetlana 2011. Ruinophilia: Appreciation of Ruins. Atlas of Transformation. Available at http://monumenttotransformation.org/atlas-of-transformation/html/r/ ruinophilia/ruinophilia-appreciation-of-ruins-svetlana-boym.html, last accessed on August 29, 2017.

Chabior, Barbara 1992. Poligony złomu pełne. [Training Grounds Full of Scrap Metal.] Gazeta Wyborcza - Legnica, No. 225, p. 2.

Czarnecka, Dominika 2015. Making Sense of the Past: (Re)constructing the Local Memorial Landscape in a Post-Soviet Base in Poland. Journal of Ethnology and Folkloristics, Vol. 9, No. 2, pp. 21-40. Available at http://www.jef.ee/index.php/ journal/article/view/204, last accessed on August 29, 2017.

Czulicki, Maciej 2014. Wybrane aspekty pobytu Pótnocnej Grupy Wojsk Armii Radzieckiej $w$ Polsce $w$ latach 1945-1993 oraz wykorzystanie infrastruktury po jednostkach Armii Radzieckiej po 1993 r. [Selected Aspects of the Northern Group of Forces of the Soviet Army's Stay in Poland in the Years 1945-1993 and the Exploitation of Infrastructure Left by the Soviet Military Units After 1993.] Warszawa: Biuro Bezpieczeństwa Narodowego. Available at https://www.bbn.gov.pl/ftp/dok/19451993.pdf, last accessed on August 29, 2017.

Demski, Dagnosław \& Czarnecka, Dominika 2015. Mapping Meanings in the Post-Soviet Landscape of Borne Sulinowo. Latvijas Vēstures Institūta Žurnāls, No. 2 (95), pp. 96-120. Available at http://www.lvi.lv/lv/LVIZ_2015_files/2numurs/D_ Demski_D_Czarnecka_Mapping_LVIZ_2015_2.pdf, last accessed on August 29, 2017.

Douglas, Mary 2001 [1966]. Purity and Danger. An Analysis of the Concepts of Pollution and Taboo. London \& New York: Routledge.

Ekologia 1994 = Ekologia. [Ecology.] Moreny: Gazeta Krainy Jezior i Lasów, No. 7, p. 9. Foucault, Michel 1984. Of Other Spaces, Heterotopias. Architecture, Mouvement, Continuité, Vol. 5, pp. 46-49. Available at https://foucault.info/doc/documents/ heterotopia/foucault-heterotopia-en-html, last accessed on August 29, 2017.

Foucault, Michel 1995 [1977]. Discipline and Punish: The Birth of the Prison. New York: Vintage Books.

Giddens, Anthony 2010. Nowoczesność i tożsamość: 'Ja' i społeczeństwo w epoce późnej nowoczesności. [Modernity and Self-Identity: Self and Society in the Late Modern Age.] Warszawa: PWN.

Golon, Mirosław 1999. Północna Grupa Wojsk Armii Radzieckiej w Polsce w latach 1945-1956: Okupant w roli sojusznika. [The Northern Group of Forces of the Soviet Army in Poland in the Years 1945-1956: The Occupant as the Ally.] Czasy Nowożytne, Vol. 6, pp. 37-115.

Gródek bez żołnierzy 1993 = Gródek bez żołnierzy, ale strzeżony. [Gródek without Soldiers but Guarded.] Moreny: Gazeta Krainy Jezior i Lasów, No. 6, p. 3.

Gródek do wzięcia 1993 = Gródek do wzięcia. [Gródek to Take.] Moreny: Gazeta Krainy Jezior i Lasów, No. 4, p. 4. 
Kamieński, Zbigniew \& Czajka, Joanna \& Bałdyga, Jerzy \& Kłuciński, Jacek (eds.) 1994. Identyfikacja i wycena szkód ekologicznych spowodowanych przez stacjonujące $w$ Polsce wojska Federacji Rosyjskiej: raport końcowy. [Identification and Valuation of Ecological Damages Caused by the Russian Federation Forces in Poland: The Final Report.] Warszawa: ELWOJ-TRIO.

Karkoszka, Janusz 1993. Są, czy nie ma? [Are They or Not?] Moreny: Gazeta Krainy Jezior i Lasów, No. 4, p. 5.

Karkoszka, Janusz 1994. Kto nie chce Bornego Sulinowa? [Who Does Not Want Borne Sulinowo?] Moreny: Gazeta Krainy Jezior i Lasów, No. 6, p. 8.

Koszty przyjaźni 1993 = Koszty przyjaźni. [Cost of Friendship.] Gazeta Wyborcza, No. 191, p. 2.

Krogulski, Mariusz L. 2001. Okupacja w imię sojuszu: Armia Radziecka w Polsce 19561993. [Occupation in the Name of Alliance: The Soviet Army in Poland 1956-1993.] Warszawa: Wydawnictwo von Borowiecky.

Ktokolwiek wie 1994 = Ktokolwiek wie... [Whoever Knows...] Moreny: Gazeta Krainy Jezior i Lasów, No. 7, p. 4.

Lund, Katrín A. \& Benediktsson, Karl 2010. Introduction: Starting a Conversation with Landscape. In: Karl Benediktsson \& Katrín A. Lund (eds.) Conversations with Landscape. Farnham: Ashgate, pp. 1-12. Available at https://www.researchgate. net/publication/293313288_Conversations_with_landscape, last accessed on August 30, 2017.

Łazarewicz, Cezary 1993. Szli na północ osadnicy. [Settlers Walked Northwards.] Gazeta Wyborcza, June 5, No. 130, p. 4. Available at http://www.archiwum.wyborcza. pl/archiwum/rok+wydania/1993?ktory=1456, last accessed on August 30, 2017.

List otwarty 1994 = List otwarty Grupy Inicjatywnej Towarzystwa Rozwoju Bornego Sulinowa oraz mieszkańców miasta. [Open Letter by the Initiative Group of the Society of Development of Borne Sulinowo and by the Inhabitants of the Town.] Moreny: Gazeta Krainy Jezior i Lasów, No. 6, p. 8.

Małachowski, Krzysztof \& Szymańska, Daniela 1994. U progu rozwoju. [On the Threshold of Development.] Moreny: Gazeta Krainy Jezior i Lasów, No. 2, p. 5.

Małolepszy, Robert 1995. Raport o stanie: Pytania o Borne. [Report on the Condition: Questions about Borne.] Moreny: Gazeta Krainy Jezior i Lasów, No. 20, pp. 8-9.

Milton, Kay 1996. Environmentalism and Cultural Theory: Exploring the Role of Anthropology in Environmental Discourse. London \& New York: Routledge.

Min nie ma 1993 = Min nie ma! Ale... [There Are No Mines! But...] Moreny: Gazeta Krainy Jezior i Lasów, No. 3, p. 5.

Mirzoeff, Nicholas 2016. Jak zobaczyć świat. [How to See the World.] Kraków \& Warszawa: Karakter.

Murphy, Dean E. 1994. Nowe życie w polskim Dodge City. [New Life in the Polish Dodge City.] Moreny: Gazeta Krainy Jezior i Lasów, No. 1, pp. 4-5.

Pisali o nas 1995 = Pisali o nas. [They Were Writing about Us.] Moreny: Gazeta Krainy Jezior i Lasów, No. 10, p. 8.

Poczobutt, Alicja 2003. Zanim otwarto miasto - część III. [Before the Opening of the City - Part III.] Magazyn Miasta i Gminy, pp. 28-29.

Pomysł na Borne 1994 = Pomysł na Borne - przywracanie życia. [Idea of Borne Restoration of Life.] Moreny: Gazeta Krainy Jezior i Lasów, No. 7, p. 8. 
Potwór 1994 = Potwór z Loch Ness w Jez. Pile. [Loch Ness Monster in Pile Lake.] Moreny: Gazeta Krainy Jezior i Lasów, Nos. 4-5, p. 1.

Potyrała, Bolesław 1995. Północna Grupa Wojsk Armii Radzieckiej w Polsce i w województwie legnickim. [The Northern Group of Forces of the Soviet Army in Poland and in Legnica Voivodeship.] Szkice Legnickie, Vol. 17, pp. 117-127.

Rozgoryczenie 1994 = Rozgoryczenie i wstyd. [Bitterness and Shame.] Moreny: Gazeta Krainy Jezior i Lasów, No. 6, p. 8.

Rząd 1994 = Rząd. [Government.] Moreny: Gazeta Krainy Jezior i Lasów, Nos. 4-5, p. 5. Są, czy 1993 = Są, czy nie ma? [Are They or Not?] Moreny: Gazeta Krainy Jezior i Lasów, No. 4, p. 1.

Szpindor, Robert 1992. Garnizon do wynajęcia. [The Garrison to Rent.] Gazeta WyborczaKoszalin, No. 235, p. 5.

Sztyler, Andrzej 1994. Kresowiacy w Gródku. [East Poles in Gródek.] Moreny: Gazeta Krainy Jezior i Lasów, No. 6, p. 15.

Sztyler, Andrzej 1995. Gródkowe dylematy. [Dilemmas in Gródek.] Moreny: Gazeta Krainy Jezior i Lasów, No. 12, pp. 12-13.

Szulc, Tomasz \& Nicpoń, Krzysztof 2007. Magazyny broni jądrowej na terytorium Polski. [Storehouses for Atomic Weapons in Poland.] Poligon, No. 3, pp. 62-77.

Wybuchowe Borne 1995 = Wybuchowe Borne! [Explosive Borne!] Moreny: Gazeta Krainy Jezior i Lasów, No. 15, p. 1. 


\title{
MĀRCIENA - BETWEEN LEGACY AND NOSTALGIA
}

\author{
Ilze Boldāne-Zeḷenkova \\ Institute of Latvian History \\ University of Latvia, Latvia \\ e-mail: Ilze.Boldane-Zelenkova@lu.lv
}

\begin{abstract}
In 1993, after the Soviet army's withdrawal, the local municipal government of the tiny Latvian village of Mārciena had to take over a former residential district of the Soviet officers' families, called Gorodok, and the infrastructure of the Soviet army unit that was located in the nearby forest. Over the past twenty years, the municipality has tried to find the best solution to protect the site from decay. Businessmen have attempted to raise the profile of the area, and all of the residents have reshaped their identities within the framework of economic and political developments taking place in the country. The purpose of the article is to examine these processes of making sense of the place called Mārciena from different points of view.
\end{abstract}

Keywords: Latvia, Mārciena, nostalgia, post-Soviet military base, Soviet legacy, uses of the past

During the Soviet occupation period, a very large number of military objects were located in Latvia. Between 1944 and 1991, there were at least 777 Soviet military sites in the territory of Latvia. The total number of military personnel was around 60,000 (Upmalis et al. 2006: 118). This fact justifies the use of a phrase in Latvian historiography: "Latvia - the USSR military base" (ibid.). The military bases of the Union of Soviet Socialist Republics (USSR) were located in sites previously used for military purposes (infrastructure built for the purposes of the tsarist Russian army, and garrisons of the army of the Republic of Latvia established during the inter-war period), as well as in newly constructed areas, on plots of land nationalised from residents of Latvia, thus introducing new features into the Latvian landscape. The military object to be discussed in this article, a base built in the parish of Mārciena in 1957, was one of these new sites. The purpose of the article is to examine this territory as an arena for negotiating visions of the recent past, as well as options of the local municipality for using the past as a resource for the development of 
the settlement. Research projects and collections of documents on the Soviet army withdrawal from Latvia in $1994,{ }^{1}$ publications in mass media, statistical data and experts' interviews provide a basis for a description of Mārciena's socio-economic situation. The fieldwork took place during three days in May and June 2015. In some cases, interviews were conducted via the Internet. The respondents were inhabitants of Mārciena, from forty-five to eighty years of age.

The location of military objects has, to a great extent, determined their future in the independent Latvian state, according to at least three scenarios: 1) they have been used for their intended purposes as garrisons of the Latvian military forces or residential areas, 2) they have become abandoned ghost towns, or 3 ) the buildings and territories have been adjusted to various needs, most often for the needs of cultural institutions or forest industry enterprises. The adverb "partially" should be used here, as the whole military complex has not always been employed for new purposes.

Unattractive scenery has been the result of various factors. First of all, Latvia does not need so many specific military objects, and therefore their maintenance is financially difficult. Secondly, Latvia features negative natural population growth and the population has also declined because of emigration to the western member states of the European Union (EU) (Cimdina \& Raubiško 2012; Dzenovska 2011, 2013). Hence, there are not enough people to fill the housing left by the vast masses of the Soviet military personnel and their dependants. Thirdly, the economic situation of Latvia as a whole has limited the opportunities for local municipalities to take care of such degraded territories (above all, to prevent further degradation), and has affected the ability of the population to financially support the sites, especially in rural areas. A final barrier is the negative attitude of Latvian society toward its recent past and the post-Soviet legacy. ${ }^{2}$

The Soviet military objects built in Latvia during the years of communist regime do not have any cultural-historical value in the eyes of the Latvian state. They are not classified as state-protected historical monuments. A different situation involves the Daugavgrīva fortress, the Daugavpils fortress, Liepājas Karosta ('War Port'), and other complexes used by the Soviet army, which were built during previous historical periods: when Latvia was a part of the Russian Empire, and during the twentieth century inter-war period. The Soviet legacy - either material or intangible - has been perceived by most members of society as a burden, as something that society has to learn to deal with and that has negative associations: pollution, unwanted neighbours, changes in Latvian landscape, inexpressive architecture, etc. Ex-territorial military areas as a topic worth analysing occurs in the local and national media rather than in academic discourse. So far, the analysis of the communist regime and its 
consequences for Latvian historiography has been undertaken mostly from the viewpoint of political history (for example, the series of works "Symposium of the Commission of the Historians of Latvia", in twenty-eight volumes ${ }^{3}$ ), and it was only at the beginning of the twenty-first century that other topics beyond those mentioned above were included. For example, during this time several valuable research projects analysing the split collective memory of Latvian society, including the conflicting remembrances of World War II and post-war events, were carried out (Muižnieks \& Zelče 2011; Neiburgs \& Zelče 2012 [2011]).

The ethnic composition of the Latvian population has also been perceived as a legacy of the Soviet occupation regime. The 1989 population census showed that the proportion of Latvians in the Latvian Soviet Socialist Republic (LSSR) was no more than 52\% (Mežs 1994: 67). Other nationalities living in the LSSR gave preference to the use of the Russian language, as it was the official language in the USSR. This situation created a large group of residents of Latvia today called the Russian-speaking population. The latest census data showed that the Latvian population was $62 \%$ Latvian and 29\% Russian (Centrālās statistikas 2011). Working on the guidelines of the state integration policy, experts pointed out this problem, indicating that there were two different viewpoints regarding the twentieth century history of Latvia, especially with reference to the years of the communist regime (Ziemele 2001; Dribins \& Šnitnikovs 2007). The main problems were connected with the question of whether it was an occupation of Latvia or a voluntary incorporation into the USSR, a question closely related to the identity of a part of Latvia's Russian-speaking population. Who are they: "occupants" or "liberators"?

Another node is connected with the Latvians who fought on the side of the Nazis during World War II, and are commemorated every 16 March with a procession in Riga and other places. Despite it being determined that they were coerced to fight by the Nazi occupation power (see, e.g., Neiburgs 1999), ${ }^{4}$ those men are perceived as fascists by the neighbouring Russian Federation and the Russian-speaking population of Latvia. Since 1998, when the Foreign Ministry of Russia expressed strong condemnation of "Nazis marching in the streets of Riga" (Muižnieks \& Zelče 2011: 146), more or less sharp confrontations between the participants in the commemoration event and members of "anti-fascist" groups at the Monument of Freedom have taken place. Currently a degree of tolerance regarding the existence of alternative views related to the events of Latvian history can be observed, and celebrations of the end of World War II on Victory Day, 9 May (Den' Pobedy) with boisterous picnics and loud fireworks are perceived by the Latvian majority as a ritual necessary for the identity of one part of the society, which is related to articles 103 and 104 of the Latvian Constitution (LR Satversme 1922) on the freedom of assembly 
and the rights of ethnic minorities to cultivate ethnic and cultural uniqueness. ${ }^{5}$ The only disputed point is the participation of state and municipal officials in those celebrations, as in the official calendar of Latvia May 8 is Memorial Day, marking the defeat of the Nazis and commemorating World War II victims (Ločmele \& Procevska \& Zelče 2011).

Despite the presence of new topics related to the communist regime in the Latvian historiography, there is a lack of evaluation of the fate of former Soviet military complexes. One of the tasks of this article is to contribute to the Latvian historiography by opening a discussion on this topic. The theoretical framework of the study is formed by works of authors who examine key areas of the chosen topic: post-Soviet bases in Central and Eastern Europe (Demski \& Czarnecka 2015), senses of place (Ashword \& Graham 2005), communities of memory (Halbwachs 1950; Kaprāns 2013; Truc 2011), legacy and uses of the past (Lowenthal 1985; Noyes 2016) and nostalgia (Boym 2001).

The framework of the present analysis is shaped by a few key notions. As these notions can be defined in different ways, it is necessary to first explain how I understand them. On the notion "uses of the past", I share the position of David Lowenthal (1985) regarding the traits that make the past helpful to people, making it possible to locate lives in linear narratives that connect the past, present, and future, and to use these narratives as economic resources.

The term "senses of place" herein is understood as products of the creative imagination of the individual and of society. Different people at different times and for different reasons create different narratives of belonging; thus heritage is as much about forgetting as about remembering the past (Ashword \& Graham 2005: 3).

The notion "legacy" is a proper term and discursive practice referring to remnants of the Soviet past, and is used as such in this study about Mārciena. Here I am using the definition given by Dorothy Noyes (2016: 388), who says that "legacy is what you keep on life support because you can't afford to kill it off".

The narratives of local people and an interview with the head of the local government led me to pay attention to nostalgia. Nostalgia is the object of many investigations in various scientific disciplines (e.g. sociology, psychology, and literature), which use many forms of the term: "restorative" and "reflective" nostalgias (Boym 2001: 49), "official" and "non-official" nostalgias, "private" and "collective" nostalgias (Davis 1979: 122), and "mobile" nostalgias (Bonnett \& Alexander 2013). Nostalgia, in the sense of a "longing for what is lacking in a changed present... a yearning for what is now unattainable, simply because of the irreversibility of time" (Pickering \& Keightley 2006: 920), is a central notion that permeates present-day discourses and practices (Angé \& Berliner 2016 [2014]: 2). 


\section{HISTORY OF MĀRCIENA}

To use Maurice Halbwachs's (1950: 2) term, the places where the Soviet military bases were built were not "empty blackboards". Mārciena is a small parish in Madona County; according to the latest census data, from 2011, it had 984 inhabitants. ${ }^{6}$ The history of the parish under the name Marxne dates back to the thirteenth century (Linin̄s 2013). Before 1957, it had never been used for military purposes. For centuries, the Mārciena parish territory was the property of Baron Tiesenhausen's family. The last owner of the Mārciena estate was Baron Woldemar von Maydell, Landrat of the Vidzeme province. The manor house of the estate was burnt down during the revolution of 1905. According to a popular legend, fearing the establishment of Soviet power, the baron burnt the manor house and committed suicide in 1918.

During the inter-war period, as elsewhere in the rural regions of Latvia, the main economic activity in Mārciena parish was agriculture, and the processing of such agricultural products as flax, milk, and grains (Liniňs 2013; Iltnere 2002: 30-33). Mārciena railway station, built on the Plavinas-Valka line in the inter-war years, provided an important stimulus for the further development of the settlement.

The largest concentration of the population and hence the development of the parish and village took place in the second half of the twentieth century, during the years of the communist regime in Latvia, and this was due to several socio-economic factors and political aims of the regime. The ideological course of the USSR, directed against private property, and an economy oriented towards collectivisation eradicated the individual farmsteads characteristic of the Latvian cultural-historical landscape, creating kolkhozes and kolkhoz villages. Kolkhoz villages formed on the basis of existing villages (in the case of Mārciena, it was a settlement that evolved near the centre of the Mārciena estate) and were complemented with new buildings constructed according to model projects, e.g. "Livani houses" or multi-storey blocks of flats. One of the kolkhozes established in Mārciena, Zelta Druva ('Golden Field', 1949), specialised, among other things, in fur animal breeding, which demanded the involvement of professionals. Specialists were also needed for the branch of the chemical manufacturing company Aerosols (est. 1964).

However, the biggest changes to the landscape of the site and to the size and ethnic composition of the local population were caused by the building of a military base ${ }^{7}$ (1957) in the forest, two kilometres from the village, and a residential area for officers' families, located nearby. The River Ārona formed a natural border between the two parts of Mārciena: on one of the banks was the residential area of the officers' families and on the other the kolkhoz village. 
Similar to a practice common in other residential areas of the Soviet military personnel in Latvia, a (re)naming of the site took place in Mārciena. New names of places were usually in the Russian language because of the ethnic background or native language of the residents. ${ }^{8}$ The name Gorodok ('township') was chosen and used by the inhabitants of the site instead of the official name of the officers' residential area, Mārciena 2, and it was also accepted by the people of Mārciena on the other side of the River Ārona. Gregory Ashworth and Brian Graham (2005: 16) note that naming places is both a necessary means of recognition and communication and a fundamental means of laying claim to territory. The definition of a place can be a part of the broader processes of inclusion and exclusion (Reid 2005: 48). It is a question of belonging to the place and of opportunities to use benefits offered by it. Although the residential complex in Mārciena was not an enclosed area surrounded by physical walls, and the local people worked there and could freely attend the cultural events organised there, the Soviet system itself and the data from the interviews reveal the existence of a border between "us" (family members of the military personnel) and "them" (local people, mostly Latvians).

The establishment of the Soviet military base was a vivid event in the local history, associated with at least two legends revealed in conversations with the local population and in interviews with people outside Mārciena, whose lives were also connected with the Soviet military facilities in Latvia. The first story was about the intention to build a secret, strategically important, nuclear missile base in Mārciena. However, "betrayer Penkovsky" thwarted those plans. The US intelligence service found out about it and therefore the idea was abandoned. Thus a less harmful unmanned aircraft aviation and personnel training centre was established in the forests of Mārciena. Oleg Penkovsky was a real person: a colonel in the Soviet military intelligence who collaborated with the intelligence services of the United Kingdom and the USA. In 1963 he was arrested by the Soviet authorities and executed (Schecter \& Deriabin 1992: 284). Another story was associated with a situation assessment related to ongoing construction work carried out in the nearby forest in the second half of the $1950 \mathrm{~s}$, and is attributed to a locally respected and highly appreciated educator, who said: "It was a marsh and will be a marsh!" Everyone who heard this, whether in the Latvian or Russian language, admitted that he was absolutely right. Something built in a marsh is doomed from the beginning.

Within approximately thirty years, until the withdrawal of the Soviet army, ten five-storey blocks (420 flats), a hotel for officers, a kindergarten, a library, a sports hall, a swimming area, and a shop selling food, as well as household and industrial commodities significantly different from those on sale on the other side of the River Ārona, were built in the residential area. The local kids 
whose native language was Russian attended the secondary school with Russian as the language of tuition, opened in the officers' residential area in 1964. The school for Latvian children with Latvian as the language of tuition was some distance from the centre and it was located in two buildings. Segregated stores and spetsobsluzhivanie ('special service') were characteristic of the communist regime and emphasised the special status of the party members and military personnel in the country. Latvia was not an exception.

After the collapse of the USSR, as in other places in the post-Soviet space, Mārciena inhabitants on both sides of the river (former military and civilians) faced great challenges created by the replacement of the Soviet socio-political system with a neoliberal one, which brought about a total collapse of both their economic system and social networks (Annist 2014: 101). The elimination of the kolkhoz and the Soviet military base led to unemployment. The state structures - the municipal government, school, kindergarten, library, and holiday house (which in 2016 became a nursing home) - now provide jobs for local residents. The Soviet mentality, lack of initiative (ibid.: 91) and unpredictable state tax system impeded the creation of private companies in the countryside. The withdrawal of the former Soviet army (since 28 January 1992 the Russian Federation Army) from Mārciena caused changes in the environment, and in the composition of the population, and left behind empty flats in the former residential area Gorodok (now Meža Street), which the local families characterised as disadvantageous. A respondent who had lived in the Meža Street district since it was built, stressed that blocks of flats in good condition attracted people from all over the country, and this brought about many social problems. "The train would arrive, a family would get off, and go to one of the empty flats. They would live there for a while and then leave in order not to pay the rent."9

\section{THE ARMY IS GONE, BUT ITS LEGACY REMAINS}

In 1991, independence was restored in Latvia and the requirement to withdraw the Soviet (later the Russian Federation) army from its territory was a logical consequence. Intergovernmental negotiations were long-lasting, at times destructive, and their price was high: no restitution for the polluted and littered land and forest areas, 25,000 of the retired military personnel ${ }^{10}$ would remain in Latvia and be given social guarantees, etc. (Jundzis 2014: 12-13). To rid the country of the presence of the foreign army was the highest priority at that time. In 1993, the soldiers, officers and their family members located in Mārciena left the country. According to the data provided by the head of Mārciena parish, some eight or ten families of retired officers chose to remain under conditions of intergovernmental agreements ${ }^{11}$ regarding army withdrawal. 
Mārciena is one of the numerous ex-territorial areas in Latvia facing similar problems: the preservation and maintenance of buildings, removal of ruins, the need for improvement in natural and social environments, and difficulties in retaining human resources. The Mārciena municipality focused on solving the problems related to the post-Soviet legacy by selling the forest areas in which the infrastructure of the former Soviet military base was located. The parish got rid of the territory by selling it to local timber businesses. ${ }^{12}$ According to the land reform of the $1990 \mathrm{~s}$, part of the territory was also given back to private owners. The buildings of the former military base, with the exception of hangars which are used for the timber business, have fallen into ruin (Figs. 1 and 2).

The former residential area of the family members of the military personnel experienced large changes in population ${ }^{13}$ triggered by coincidence and the practice of sending to Mārciena "unfavourable" families from all of the parishes of Madona County, ${ }^{14}$ a plan developed by the Madona County government. These new inhabitants are believed to have had a disruptive impact on the condition of the surrounding buildings: windows broken, wooden parts removed and used as firewood, etc. As was stated by the current head of the municipal government, migration and changes in the population were huge at that time, and social problems still partially remain (Figs. 3 and 4).

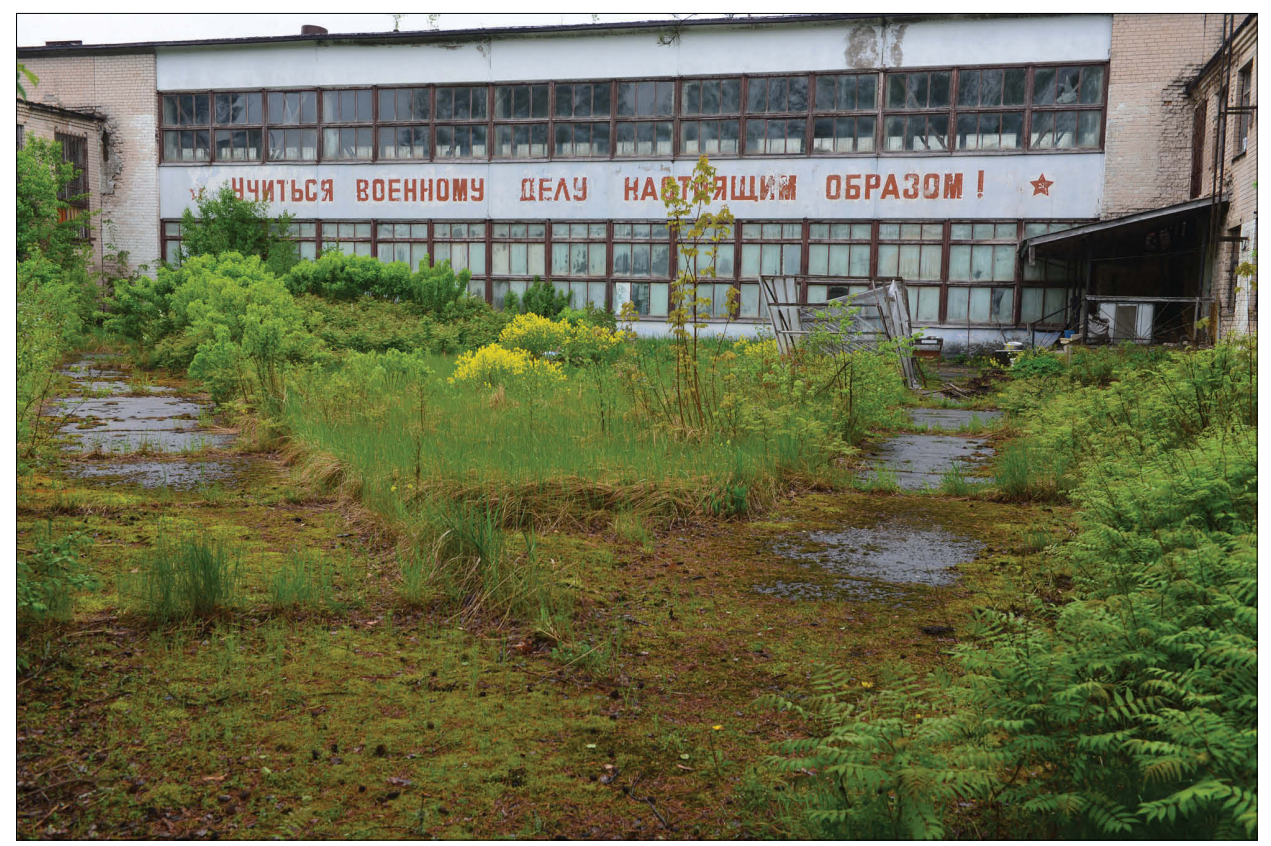

Figure 1. Post-Soviet military base in the Mārciena forest. The slogan on the wall, "To learn the art of war properly!", is a quote from a 1918 speech by V. I. Lenin. Photograph by Dagnostaw Demski 2015. 


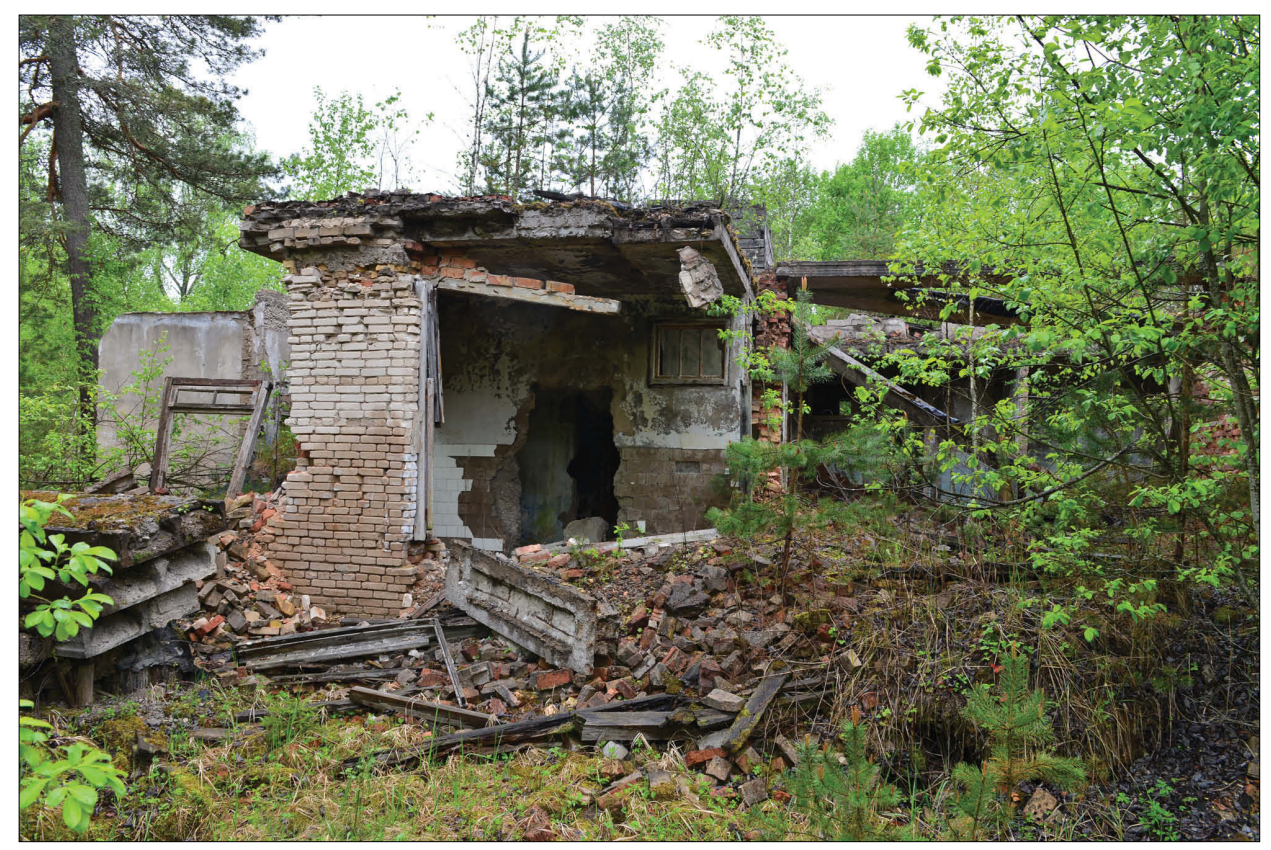

Figure 2. Post-Soviet military base in the Mārciena forest. Photograph by Dagnostaw Demski 2015.

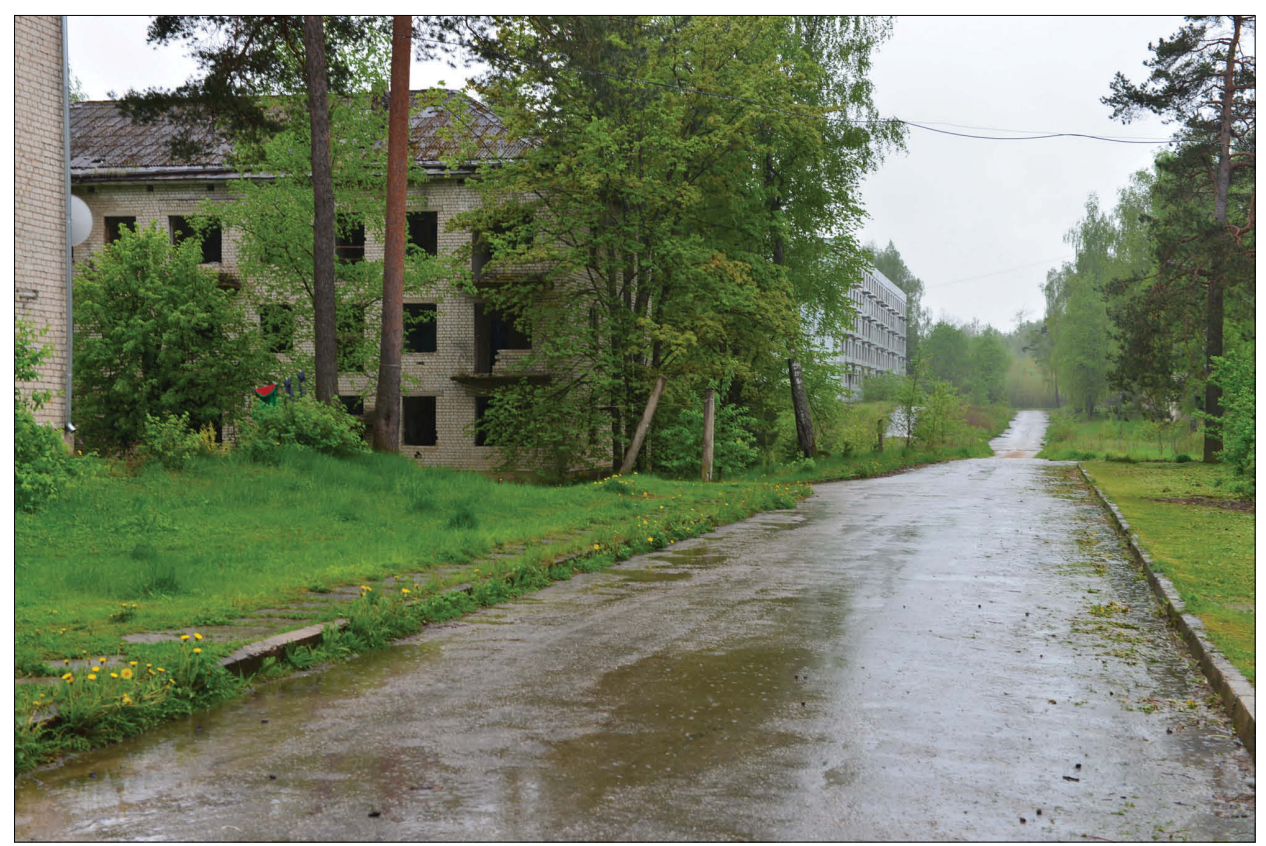

Figure 3. The left side of Meža Street in Mārciena (former Mārciena 2). Photograph by Dagnostaw Demski 2015. 


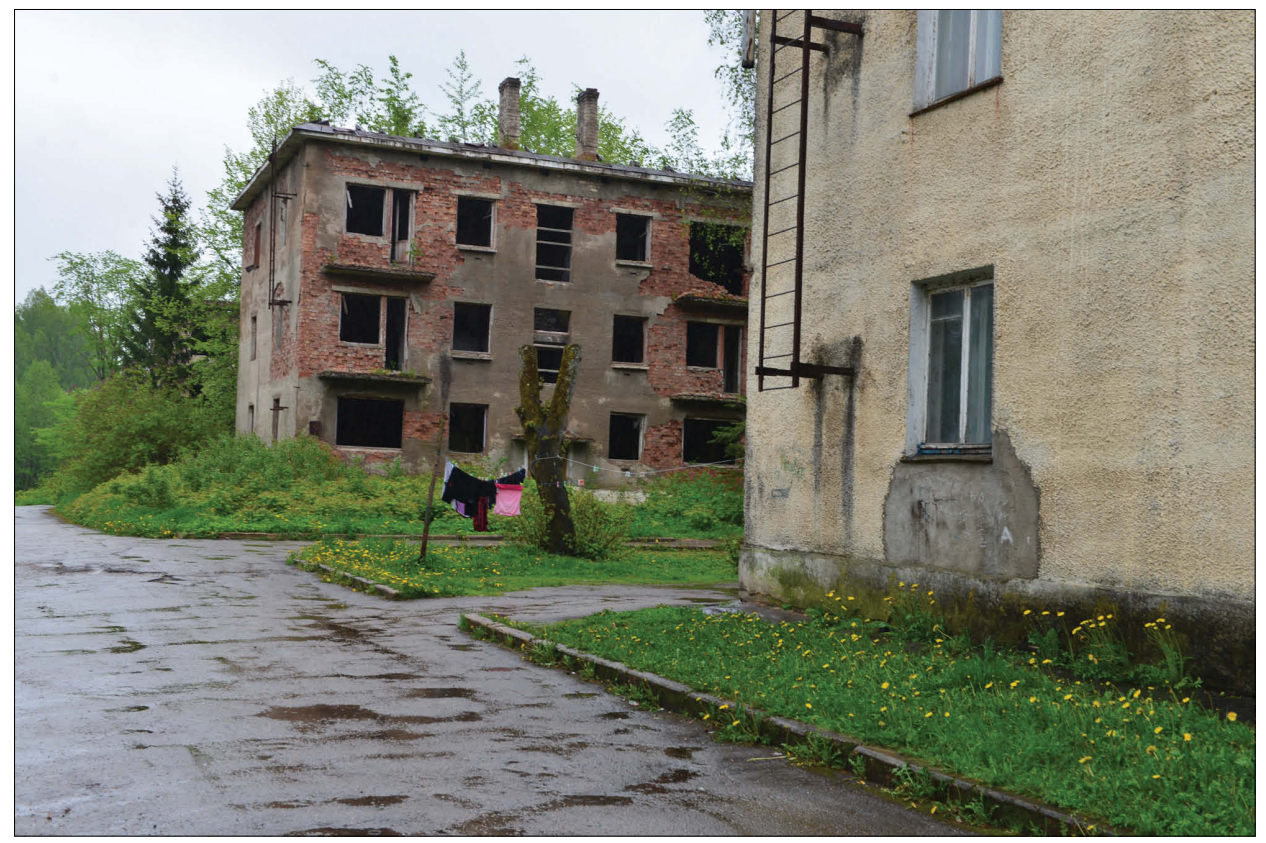

Figure 4. The right side of Meža Street in Mārciena (former Mārciena 2). Photograph by Dagnostaw Demski 2015.

The municipal government aims to revitalise this place, to make it attractive as a residential area and thus to increase the revenue of the municipality. Local governments have participated in several European Union projects, including the international EU project INTERREG III B Baltic Sea Region programme project ReMiDo (2005-2007), the purpose of which was to facilitate the role of the state and municipal governments, private and non-governmental organisations, and to increase the development of residential areas by applying the experience of other countries. Five countries - Lithuania, Estonia, Germany, Poland, and Sweden - participated in the project along with Latvia (Pukīite 2006, 2007). Despite the fact that due to their critical technical condition seven out of ten blocks of flats are awaiting demolition (the municipality does not have the financial means to undertake this), all of the public buildings - a school, a club, and a hotel (till 2015 a former kindergarten, and currently a nursing home for sixty-one people from all over Madona County) - have been preserved, renovated, and are still functioning. 


\section{MĀRCIENA AS A TOURISM SITE: POTENTIAL AND MISSED OPPORTUNITIES}

While, as mentioned above, the municipality put effort into finding the best ways to use the post-Soviet legacy to increase its revenues, as well as improving the well-being of the population, local businessmen, driven by economic interests, worked to improve the profile of the site. Among other local sightseeing objects, local businessmen supported the restoration of St. Aleksey Orthodox Church and the creation of the symbolic stone dedicated to the 800th anniversary of Mārciena.

In terms of Mārciena's status in the context of other Latvian sites, the first thing the place is associated with is the phrase "Mārciena estate", which under closer examination turns out to be just a brand: the name of the spa resort and a popular recreation place, having a distant connection with the Mārciena manor, which belonged to Baron von Maydell. It should be noted that the promotion of the brand "Mārciena estate" aroused loud polemics between historians and the owner of the property on the uses of the name "Mārciena estate" and the creation of myths about it (Zvirgzdiñs 2003). The fact that the widely advertised spa resort is situated in the former merchant's residence, Patmalnieki (a school until 1994), and not in the building of the Mārciena manor, triggered this dispute.

Tourist sites in Mārciena parish include several nature and historical monuments: the Krustkalni nature park with a path to Lake Dreimani, the Mārciena manor buildings and park (1830), the renovated St. Aleksey Orthodox Church, built in 1872 (Iltnere 2002: 32), the memorial stone dedicated to the 800th anniversary (2013), etc. There are also two places connected with the Soviet occupation period: a memorial dedicated to repressed Mārciena residents and the Brethren Cemetery of the Soviet soldiers killed in World War II, which are significant ritual remembrance and commemoration places for different memory communities.

Some opportunities have been missed. In the list of tourist sites (see http:// www.marciena.lv/turisms-marciena), there are none connected with the former military base or those in the surrounding area related to it. This leads to two questions: "Should there be?" and "Why aren't there?". Skilfully communicated and promoted as a tourism product, it would be a good way to use the heritage of the recent past, and the local municipality could benefit from it. As a positive example, Borne Sulinowo (Poland) can be mentioned (Demski \& Czarnecka 2015).

There are several answers to the question of why this post-Soviet legacy is not used as a tourism product. First of all, the legal entities and private individuals who became owners of the forest areas around the former military base chose forestry rather than tourism as their business activity. The history of Latvia 
shows (e.g., regarding the former rocket base in Zeltini) that it is almost impossible for several owners to agree on establishing one tourism object, ${ }^{15}$ especially considering the low popularity of tourism related to the Soviet past (compared to Lithuania, where it is widely popular (Angé \& Berliner 2016 [2014]: 6-7)). Secondly, it is understandable that associating Mārciena with a complex of renovated buildings from the nineteenth century, the "Mārciena estate", about which the narrative has not been preserved in the memory of the local society, is more pleasant than associating it with the ruins of the former military base in the Mārciena forest or with empty houses in Mārciena's Meža Street.

There is also the question of supply and demand, and the willingness and efforts to promote the post-Soviet legacy as a tourism product, i.e., dealing with the wider social, economic, and political context and with forgetting and remembrance in the creation of the sense of the place.

The international situation (including the military conflict in Ukraine) and the warring memories in the Latvian public space still do not allow Latvians (even on the governmental level) to look at the Soviet past and post-Soviet legacy without suspicion. Military facilities that were built before the Soviet occupation and represented architecture of other epochs had higher status in the independent Latvian state. Many of them were assigned the status of cultural monuments of state or local significance, ${ }^{16}$ which proved that they belonged to the Latvian cultural heritage and accentuated their place and significance in the historical memory of the society (Mintaurs 2012, 2013): the Daugavgrīva fortress (2003), the Liepāja naval port (separate buildings: 2005 and 2010), the Daugavpils fortress (1998), and the Krustpils castle (1998). Facilities of this kind serve as clear evidence of the state's memory politics.

\section{GORODOK - RECOLLECTION WITH NOSTALGIA}

Past events in our memory are tightly connected with memories about the places where they happened. Maurice Halbwachs (1950: 14-15) refers to the intrinsic spatiality of memory, which can be explored through cultural and social practices, activities, and enactments, which symbolically reinforce or challenge the collective memories inherent in physical landscapes, practices that frequently provide the core emotional attachments, linking communities to their environments.

Every place can possess several senses connected with different historical periods and various communities of memory. People can be nostalgic for time or place, or a place in time. Svetlana Boym (2001: 21) acknowledges that nostalgia is not just mourning for an ideal past, but for the perfect present and its lost potential, and this is a key point in the context of the residents of Mārciena, who, as in Latvia as a whole, are divided into people belonging to 
different ethnolinguistic groups and memory communities. At the same time, these people accept and sometimes even share each other's feelings towards the native language and common past. Despite joyful expressions in the public space over liberation from the army presence, ${ }^{17}$ the residents of Mārciena vividly and with a certain nostalgia remember times in the village's history connected with the Soviet army's presence there: while the Latvian ethnolinguistic group have tried to escape from the present (Sedikides et al. 2008: 306), the Russian speakers mourn the loss of the power and privileges they had in the Soviet times. The common ground of both groups' narratives about Gorodok includes a yearning for the lost social well-being, a clean environment and good neighbours. It should be acknowledged that Meža Street is very well maintained, but the skirmishes have left an impression on the landscape.

In spite of the lack of a physical wall, the symbolic borders established by the socialist system between the inhabitants of the two parts of Mārciena were obvious. There were local people and people from Gorodok (an oasis), who did not experience deficits or other common daily problems. A family member of a retired officer emphasised the openness of Gorodok, talked about the possibility of purchasing goods in the specialised store, and said: "We shared our pleasures". ${ }^{18}$ No matter which group one belonged to, the memories of ladies wearing fur coats, of flower beds in front of the houses, and cultivated garden allotments are much more appealing than the present grey daily life. In interviews, the residents of Gorodok (the Russian-speaking group) stressed the positive self-evaluation and recognised position in the society at that time compared with now, constantly being on the defensive regarding their language skills, their reasons for staying in Latvia, etc. Sociological studies have revealed that the change in the social status of the Russian-speaking group was a traumatic experience for them (Apine \& Volkovs 2007; Hanovs \& Viṇnika 2006: 205).

The term "mobile nostalgias" was coined "to open up the complex relationship between the city and those who have left it" (Bonnett \& Alexander 2013: 391). People who completely share a longing for the memory community of the retired Soviet officials and their family members, i.e., for a lost past, are those who moved to Yegoryevsk, on the outskirts of Moscow, and to other places where they were assigned during the withdrawal of the Soviet armed forces. Mourning was connected with age (the time of their youth) and with the time of their privileged social status. Cyberspace, by making the bric-a-brac of nostalgia available in digital form, and making it more desirable than the real past (Boym 2001: 347), is an appropriate space for sharing nostalgia. Boym acknowledges that "on the blue screen two scenarios of memory are possible: a total recall of undigested information bytes or an equally total amnesia that could occur in a heartbeat with a sudden technical failure" (ibid.). Cyberspace as a site for meeting others is actively used both by those retired Soviet officials 
and their family members who stayed in Mārciena and by those who left. Narrative data are shared in conversations, using appropriate internet tools (the most popular being www.skype.com), through exchanging pictures, home-made videos and films representing symbolic memory sites, in social networks uniting classmates ${ }^{19}$ those who served in the same army regiment ${ }^{20}$ or in the aviation units of the Soviet armed forces, ${ }^{21}$ etc. Photographic and video memories are also posted on widely known internet sites (https://yandex.ru; www.youtube. com), thus passing along messages and appealing to those who belong to this community of memories, but are not in direct contact with it. On the internet sites mentioned by the respondents, there are photographs and videos in which the symbolic memory site is confronted with its current visually unattractive physical shape. ${ }^{22}$ Laconic titles, the lack of commentaries, and dramatic and appropriate background music express the emotions that the authors of the videos have experienced. In the case of Mārciena, the author has chosen "Toccata and Fugue in D Minor" by Johann Sebastian Bach. This particular video can be found on many internet sites where the former military personnel of the USSR and the Russian Federation or their family members share their traumatic experiences in confronting symbolic memory sites and the ghost towns they have turned into. ${ }^{23}$

For former inhabitants of the residential area, which they have named Gorodok, a nostalgic song by the same name performed by the Russian singer Angelika Varum has become a kind of anthem. ${ }^{24}$ The song starts with the words:

Akh, kak khochetsia vernut'sia,

Akh, kak khochetsia vorvat'sia $v$ gorodok,

Na nashu ulitsu v tri doma,

Gde vse prosto i znakomo na denek.

Oh, how I wish to return,

how I wish to enter the township.

To come to our street, to those three houses,

where everything is so simple and familiar. For one day...

It was chosen as the soundtrack for a video about the withdrawal of the former Soviet army from Mārciena, made by one of those who left the site. ${ }^{25}$ Cyberspace offers a sense of presence for both longing and celebrating, and the most significant feast for this memory community is 9 May, Victory Day. Sociological studies confirm the fact that Russian identity in Latvia is not homogeneous and is highly influenced by the state of affairs in the Russian Federation (e.g. Hanovs \& Viṇnika 2006: 205; Kaprāns \& Procevska 2013). This is the reason why most of the Russian-speaking community in Latvia celebrate the end of World War II not on 8 May, the official date in Latvia and other EU countries, but on 9 May, the same day as in the Russian Federation. Ilva Skulte has said: 
May 9th as a symbolic date was always in the centre of the mobilising Victory narrative in Soviet as well as contemporary Russia letting no place for Baltic reservations and opposition - for Balts, this day has equally symbolic meaning of (re)establishment of Soviet regime leading to the loss of an independent state and traumatic experiences of totalitarianism [sic]. (Skulte 2016: 13; see also Grigas 2013: 127-154)

There are no monuments to liberators or memorial ensembles dedicated to the victory of the Soviet army over fascism in Mārciena. The Brethren Cemetery ${ }^{26}$ of Soviet soldiers located near the town is used as a place of commemoration for the ritual celebration of the holiday. The situation in Mārciena differs from that in Latvia as a whole in that the head of the municipal government (in office since 2005), together with an Orthodox priest, participates in the celebrations out of a desire to show respect to all of the inhabitants of the parish and a wish not to divide them by language or political affiliation. In Latvia as a whole, only the left-wing political parties, such as the Saskanas Centrs, always participate in the Den' Pobedy, celebrated by the Russian-speaking population of Latvia on 9 May.

\section{CONCLUSION}

Twenty-four years ago, many Latvian local governments were faced, among a number of other serious issues, with a challenge: what should be done with the legacy of the Soviet army? The municipality of the small Latvian village of Mārciena had to solve this problem. The Mārciena municipal government had to take over the residences of Soviet soldiers' families, known as Gorodok, and the infrastructure of the Soviet army unit located near the forest. Since 1993, the municipality has been trying to find the best solution to protect the place from collapse. Local entrepreneurs, by developing their businesses, including tourism, have done much to promote Mārciena's image. All of the residents of Mārciena have tried to find their places and roles within the current economic and political development of independent Latvia.

The rapid transition from the Soviet economic system to neo-liberalism resulted in unemployment, shortages and, hence, apathy among the local population, and this did not make it easier for the municipality to solve the problem of the post-Soviet legacy. European Union funds and financial support from the government of Madona County made it possible to rebuild and utilise several buildings in the former residential area, thus using the past's heritage for the benefit of the community. Unfortunately, part of the housing, as well as the former military base buildings in the woods - historical remnants - have continued to deteriorate. 
The past was also used to search for business opportunities in Mārciena and to create significance for the site. The spa resort located in the former school building (from the nineteenth century) used the well-known but pretentious name "Mārciena Manor". This demonstrated the spirit of the time when it was popular to modernise manors and remember the contribution of the Baltic Germans to the development of Latvian cultural environment.

The change in political power resulted in changes in topography; the place name from the Soviet period was replaced by a new one: Meža Street, Mārciena. Nevertheless, Gorodok continues to exist in the memories of Mārciena residents as a symbol of a certain space of time.

The difficult transition from socialism to capitalism brought poverty, low selfconfidence, and loneliness for many rural inhabitants, which in turn triggered nostalgia. Despite belonging to different ethnolinguistic groups and memory communities, both groups of Mārciena residents are nostalgic: military retirees longing for the lost past and their lost status, and locals yearning not for a return of the past but for something better than the present difficulties. Both groups long for an orderly environment, for the order present in Gorodok during the Soviet era.

Cyberspace, providing the opportunity to virtually share longings for the past and to celebrate the holiday, can unite everyone connected to Mārciena: both the local residents and those who left Mārciena in 1993. Similar to other places in Latvia, there is also a memory place in Mārciena, where on 9 May, together with people sharing a similar interpretation of the past based on Soviet historiography, Victory Day is celebrated, which is also supported by the municipal government. In conclusion, I would like to quote Svetlana Boym's statement (2001: 354-355), which I agree with:

Nostalgia can be both a social disease and a creative emotion, a poison and a cure. The dreams of imagined homelands cannot and should not come to life. They can have a more important impact on improving social and political conditions in the present as ideals, not as fairy tales come true. Sometimes it's preferable (at least in the view of this nostalgic) to leave dreams alone, let them be no more and no less than dreams, not guidelines for the future.

\section{ACKNOWLEDGEMENTS}

The author's work on this article constitutes a part of the UL project No. AAP2016/ B060. The author's special thanks go to Ināra Mālniece, the head of the Mārciena parish government, Aldona Gudrīte, the director of the Mārciena Elementary School, and all respondents who shared their thoughts with her. 


\section{NOTES}

1 The process of withdrawal lasted from 1991 to 1994 . Although according to the official agreement the final date for withdrawal was 31 August 1994, the Skrunda radar station remained in Russian hands till 1998, after which Russians had eighteen months to dismantle it.

2 The social memory monitoring published in Latvia in 2013 showed that a significant part of the Latvian society tolerated the co-existence of different opinions regarding the events of 1940 and the whole Soviet period, permanently represented by at least two communities of memory. Assessing the period of the communist regime in Latvian history, ethnic Latvians had shifted from a negative attitude to a pragmatic and neutral position, while the attitude of the Russian-speaking population of Latvia had become more positive towards this period (Kaprāns \& Procevska 2013; Kaprāns 2013). It should be mentioned that this monitoring was carried out in 2012 , but events in Ukraine, where in certain situations clear similarities with the events in Latvia in 1940 can be observed, in my viewpoint have significantly damaged that neutral attitude towards the period of the communist regime and the Soviet era in Latvia.

3 The Commission of the Historians of Latvia was founded in 1998 on the initiative of the then president of Latvia, Guntis Ulmanis. The aim of the commission was and still is to conduct detailed research on the politics of the Nazi and Soviet regimes (see http://www.president.lv/pk/content/?cat_id=7; last accessed on September 25, 2017).

4 By forming the Latvian Volunteer SS Legion, the Nazis violated the Fourth Hague Convention (from 1907, on the Laws and Customs of War on Land) and thus committed yet another war crime (Krūmiñš 2017: 6). There was no volunteering. Those who did not enlist during the announced mobilisation were imprisoned in concentration camps for six months and then sent to the legion. Later on, the death penalty was imposed for evading mobilisation.

5 Article 103: "The State shall protect the freedom of previously announced peaceful meetings, street processions, and pickets"; Article 104: "Persons belonging to ethnic minorities have the right to preserve and develop their language and their ethnic and cultural identity" (LR Satversme 1922).

6 See the Central Statistical Database, available at http://data.csb.gov. lv/pxweb/lv/tautassk_11/tautassk_11__tsk2011/TSG11-01.px/table/ tableViewLayout2/?rxid=6b213b07-c02d-49b7-badb-3d7ced80fdff, last accessed on September 25, 2017.

7 Military units based near Mārciena: No. 10211-275 - Separate Unmanned Aircraft Squadron; No. 22799-14 - Separate Unmanned Reconnaissance Plane Squadron; No. 14154-924 - Military Training Centre for Personnel; and No. 68505 - a separate Baltic Fleet Sea Squadron, established in 1957 (Upmalis et al. 2006).

8 In Alūksne, for instance, it was Lugovcovo (by analogy with the street name), and in Krustpils it was Zamok ('castle'): this name was determined by the location of the military base and the officers' residential area in the territory of the Krustpils castle.

9 Interview, 21 May 2015.

${ }^{10}$ An estimated 75,000 to 100,000 people, including family members, which was a significant number considering that in the early 1990s the proportion of ethnic Latvians in the Latvian population was only a little over 50\% (Jundzis 2014: 12-13). 
11 "Agreement between the Government of the Republic of Latvia and the Government of the Russian Federation on the social protection of the retired military personnel of the Russian Federation and their family members residing in the territory of the Republic of Latvia", and "Agreement between the Republic of Latvia and the Russian Federation on terms, time limits, and the procedure for a complete withdrawal of the armed forces of the Russian Federation and the legal status thereof during the withdrawal from the territory of Latvia" (Upmalis et al. 2006; Jundzis 2014).

${ }^{12}$ According to the homepage data of Mārciena parish, there are three companies involved in the timber business there: Mārciena Wood, Damaksnis, and ILBU (see http://www. marciena.lv/marcienas-pagasta-uznemumi; last accessed on October 2, 2017).

${ }^{13}$ Publicly available data show the ethnic diversity of the Mārciena population. In addition to Latvians, Russians, Belarussians, Gypsies, Poles, Ukrainians, Lithuanians and others live there. The Mārciena website shows data from 2006: the total number of inhabitants - 1164, Latvians - 855 (73.5\%), Russians - 179 (15.4\%), Byelorussians $31(2.7 \%)$ (see http://www.marciena.lv/turisms-marciena/skaitli-un-fakti, last accessed on October 2, 2017).

${ }^{14}$ Madona County was founded in 2009 and it incorporates the city of Madona and fourteen municipalities. This is the third largest county in Latvia and the largest in the Vidzeme region. The county covers approximately 2153.4 square kilometres and about 25,515 people live there (as of 1 January 2016). The distance between Riga and Madona is 166 kilometres.

${ }^{15}$ A museum in Zeltini (in the Alūksne region) attempted to convert the former Soviet army nuclear missile base near Zeltini to a tourist attraction (see http://www.vietas. lv/eng/objekts/bijusa_psrs_strateiska_kodolrakesu_baze_pie_zeltiniem/, last accessed on October 3, 2017). However, for economic reasons, several owners of this particular plot of land refused to agree to create a common usage tourism object and to maintain it as a "burden of history".

${ }^{16}$ See Valsts aizsargājamo kultūras piemineklu saraksts (List of State-Protected Cultural Monuments), available at http://likumi.lv/doc.php?id=50976; last accessed on October 3, 2017.

${ }^{17}$ See the homepage of the spa hotel Mārcienas muiža. Available at http://www.marciena. eu/index.php/en/we/history, last accessed on October 3, 2017.

18 Interview excerpt. Mārciena, May 2015.

${ }^{19}$ For example, the Odnoklasniki.ru (classmates) website. Available at https://ok.ru/, last accessed on October 3, 2017.

${ }^{20}$ For example, the Odnopolchane.net (fellow soldiers) website. Available at http://www. odnopolchane.net/, last accessed on October 3, 2017.

${ }^{21}$ For example, the Forumavia.ru website. Available at http://www.forumavia.ru/ forum/1/1/193544736490015480901227182111_5.shtml, last accessed on October 3, 2017.

${ }^{22}$ See https://fotki.yandex.ru/users/bir4onok/album/174326; https://www.youtube.com/ watch?v=g_sCPPeVW2g; https://www.youtube.com/watch?v=vJfOYUS_EBo; all last accessed on October 3, 2017. 
${ }^{23}$ See http://notebookvideo.ru/1h-gKvhZd8/rekviem_po_gorodkam_gde_my_sluzhili. html, last accessed on October 3, 2017.

${ }^{24}$ One part of the format of illustrations added to this song is available at https://www. youtube.com/watch?v=3-3Nlt8fQ0o, last accessed on October 3, 2017.

${ }^{25}$ One copy of the video-tape was given as a gift to the school, but it was not possible to see it. Unfortunately, the tape had been lost.

26 "Agreement between the government of the Republic of Latvia and the government of the Russian Federation on the status of Latvian burials in the territory of the Russian Federation and the status of Russian burial grounds in the territory of the Republic of Latvia" (2007). The agreement also determines the conditions under which the cemeteries are to be maintained by local municipalities.

\section{REFERENCES}

Angé, Olivia \& Berliner, David (eds.) 2016 [2014]. Anthropology and Nostalgia. New York \& Oxford: Berghahn.

Annist, Aet 2014. Losing the Enterprising Self in Post-Soviet Estonian Villages. In: Nicolette Makovicky (ed.) Neoliberalism, Personhood, and Postsocialism: Enterprising Selves in Changing Economies. Surrey \& Burlington: Ashgate, pp. 89-108.

Apine, Ilga \& Volkovs, Vladislavs 2007. Latvijas krievu identitāte: vēsturisks un sociologisks apcerējums. [Russian Identity in Latvia: A Historical and Sociological Study.] Riga: LU FSI.

Ashworth, Gregory J. \& Graham, Brian 2005. Senses of Place, Senses of Time and Heritage. In: Gregory J. Ashworth \& Brian Graham (eds.) Senses of Place: Senses of Time. Heritage, Culture and Identity. Aldershot: Ashgate Publishing, pp. 3-12.

Bonnett, Alastair \& Alexander, Catherine 2013. Mobile Nostalgias: Connecting Visions of the Urban Past, Present, and Future amongst Ex-Residents. Transactions of the Institute of British Geographers, Vol. 38, No. 3, pp. 391-402. DOI: 10.1111/j.14755661.2012.00531.x.

Boym, Svetlana 2001. The Future of Nostalgia. New York: Basic Books.

Cimdiņa, Agnese \& Raubiško, Ieva 2012. Cilvēks un darbs Latvijas laukos. Sociālantropologisks skatījums. [Man and Work in the Latvian Countryside: A Social and Anthropological View.] Riga: Zinātne.

Davis, Fred 1979. Yearning for Yesterday: A Sociology of Nostalgia. New York: Free Press.

Demski, Dagnosław \& Czarnecka, Dominika 2015. Mapping Meanings in the Post-Soviet Landscape of Borne Sulinowo. Latvijas Vēstures Institūta Žurnāls, No. 2 (95), pp. 96120. Available at http://www.lvi.lv/lv/LVIZ_2015_files/2numurs/D_Demski_D_ Czarnecka_Mapping_LVIZ_2015_2.pdf, last accessed on October 3, 2017.

Dribins, Leo \& Šṇitṇikovs, Aleksejs (eds.) 2007. Pretest̄̄ba sabiedrūbas integrācijai: Cēloṇi un sekas. [Resistance to Integration of the Society: Causes and Consequences.] Riga: LU FSI, İUMSILS.

Dzenovska, Dace 2011. Notes of Emptiness and the Importance of Maintaining Life. The Anthropology of East Europe Review, Vol. 29, No 2, pp. 228-241. Available at https://scholarworks.iu.edu/journals/index.php/aeer/article/view/1248/1337, last accessed on October 3, 2017. 
Dzenovska, Dace 2013. The Great Departure: Rethinking National(ist) Common Sense. Journal of Ethnic and Migration Studies, Vol. 39, No. 2, pp. 201-218. http://dx.doi. org/10.1080/1369183X.2013.723254.

Grigas, Agnia 2013. The Politics of Energy and Memory between the Baltic States and Russia. Surrey \& Burlington: Ashgate.

Halbwachs, Maurice 1950. Space and the Collective Memory. In: Maurice Halbwachs. The Collective Memory. Available at http://web.mit.edu/allanmc/www/hawlbachsspace. pdf, last accessed on October 3, 2017.

Hanovs, Deniss \& Vinnika, Irina 2006. Russians and Russian-Speaking Population in Latvia: Diaspora and Technologies Cultural Memory. In: Žaneta Ozoliṇa (ed.) Expanding Borders: Communities and Identities. Proceedings of International Conference Riga, November 9-12, 2005. Riga: LU Akadēmiskais apgāds, pp. 185-208.

Iltnere, Astrida (ed.) 2002. Latvijas pagasti: Enciklopēdija. [Parishes in Latvia: Encyclopaedia.] Vol. 2. Riga: Preses Nams.

Jundzis, Tālavs 2014. Krievijas karaspēka izvešana no Latvijas 1992-1994: Diplomātijas uzvara vai politiska piekāpšanās? [Removal of Russian Federation Armed Forces from Latvia: A Diplomatic Success or Political Concession?] Latvijas Zinātñu Akadēmijas Vēstis, Section A, Vol. 68, No. 3-4, pp. 4-23. Available at http:// www.lza.lv/index.php?option=com_content\&task=view\&id=2263\&Itemid=400, last accessed on October 3, 2017.

Kaprāns, Mārtiṇš 2013. Padomju laika sociālās reprezentācijas latvijas sabiedriskajā domā (2004-2012). [The Social Representations of the Soviet Period in Latvian Public Opinion (2004-2012).] Latvijas Vēstures Institūta Žurnāls, No. 2 (87), pp. 102138. Available at http://www.lvi.lv/lv/LVIZ_2013_files/2numurs/M_Kaprans_ Padomju_laika_socialas_LVIZ_2013_2.pdf, last accessed on October 4, 2017.

Kaprāns, Mārtiņš \& Procevska, Olga 2013. Latvijas sociālās atminas monitorings: Zinojums Nr. 1. [Monitoring on Latvian Social Memory: Report No. 1.] Riga: University of Latvia. Available at http://www.academia.edu/3232032/Latvijas_ soci\%C4\%811\%C4\%81s_atmi\%C5\%86as_monitorings_Zi\%C5\%86ojums_Nr._1, last accessed on October 4, 2017.

Krūmiṇš, Gatis 2017. Gan nacistiskā Vācija, gan staḷiniskā PSRS Otrajā pasaules karā bija Latvijas Republikas ienaidnieces. [Both the Nazi Germany and the Stalinist USSR in the Second World War Were Enemies to the Republic of Latvia.] Available at http:// www.va.lv/sites/default/files/2pk_2017.marts_.pdf, last accessed on October 4, 2017.

Linin̄š, Uldis 2013. Mārcienas pagasts. [Mārciena Parish.] Mārciena: Mārcienas pagasta pārvalde.

Ločmele, Klinta \& Procevska, Olga \& Zelče, Vita 2011. 8./9. maijs Latvijā. [May 8-9 in Latvia.] In: Nils Muižnieks \& Vita Zelče (eds.) Karojošā piemiņa: 16. marts un 9. maijs. [Warring Memories: 16 March and 9 May.] Riga: Zinātne, pp. 236274. Available at https://dspace.lu.lv/dspace/handle/7/31243, last accessed on October 4, 2017.

Lowenthal, David 1985. The Past is a Foreign Country. Cambridge: Cambridge University Press.

LR Satversme 1922. [Constitution of the Republic of Latvia.] Available at http://likumi. lv/doc.php?id=57980, last accessed on September 25, 2017.

Mežs, Ilmārs 1994. Latvieši Latvijā: Etnodemogrāfisks apskats. [Latvians in Latvia: An Ethno-Demographic View.] Riga: Zinātne. 
Mintaurs, Mārtiṇš 2012. Kultūras mantojums un vēsturiskā atmiṇa Latvijas PSR: Rīgas Lielo kapu rekonstrukcijas piemērs 20. gadsimta 60.-80. gados. [Cultural Heritage and Historical Memory Policy in the Latvian SSR: The Case Study of the Great Cemetery Reconstruction in Riga (1960s-1980s).] Latvijas Vēstures Institūta Žurnāls, No. 2 (83), pp. 62-88. Available at http://www.lvi.lv/lv/ LVIZ_2012_files/2numurs/M_Mintaurs_Kulturas_mantojums_LVIZ_2012_2. pdf, last accessed on October 4, 2017.

Mintaurs, Mārtiṇš 2013. Pieminekḷu valdes darbs Rīgas vecpilsētas arhitektūras mantojuma saglabāšanā vācu okupācijas laikā (1941. gada jūlijs - 1944. gada jūlijs). [Activities of the Monument Board in the Protection of Old Riga Architectural Heritage during the Nazi Occupation (July 1941 - July 1944).] Latvijas Vēstures Institūta Žurnāls, No. 2 (87), pp. 24-73. Available at http:// www.lvi.lv/lv/LVIZ_2013_files/2numurs/M_Mintaurs_Piemineklu_valdes_darbs_ LVIZ_2013_2.pdf, last accessed on October 4, 2017.

Muižnieks, Nils \& Zelče, Vita (eds.) 2011. Karojošā piemiņa: 16. marts un 9. maijs. [Warring Memories: 16 March and 9 May.] Riga: Zinātne.

Neiburgs, Uldis 1999. Latviešu karavīri Vācijas un PSRS armijās: galvenās problēmas. [Latvian Soldiers in the Armies of Germany and the USSR: Main Problems.] Konferences 'Latvijas Otrajā pasaules karā' rakstu krājums. [Proceedings of the Conference 'Latvia in the Second World War'.] Riga: Latvijas Valsts arhīvs, pp. 25-27. Available at http://www.archiv.org.lv/LVA/pdf/Tezes1999_latv.pdf, last accessed on October 4, 2017.

Neiburgs, Uldis \& Zelče, Vita (eds.) 2012 [2011]. (Divas) puses: Latviešu kara stāsti. Otrais pasaules karš karavīru dienasgrāmatās. [(Two Sides). Latvian War Stories. The Second World War in Soldiers' Diaries.] Riga: Mansards.

Noyes, Dorothy 2016. Humble Theory. Folklore's Grasp on Social Life. Bloomington: Indiana University Press.

Pickering, Michael \& Keightley, Emily 2006. The Modalities of Nostalgia. Current Sociology, Vol. 54, No. 6, pp. 919-941. http://dx.doi.org/10.1177/0011392106068458.

Puḳīe, Iveta 2006. Divi miljoni eiro bijušo militāro teritoriju sakārtošanai. [Two Million Euro for the Adjustment of Former Military Territories.] Komersanta Vēstnesis, No. 36 (42), September 13. Available at http://www.kvestnesis. lv/?menu=doc\&id=143347, last accessed on October 4, 2017.

Puḳite, Iveta 2007. Pal̄̄gā degradētām teritorijām. [Help for Degraded Areas.] Komersanta Vēstnesis, No. 6 (62), February 7. Available at http://www.kvestnesis.lv/index. php?menu=doc\&id=152646, last accessed on October 4, 2017.

Reid, Bryonie 2005. 'That Quintessential Repository of Collective Memory': Identity, Locality and the Townland in Northern Ireland. In: Gregory J. Ashworth \& Brian Graham (eds.) Senses of Place: Senses of Time. Heritage, Culture and Identity. Aldershot: Ashgate Publishing, pp. 47-60.

Schecter, Jerrold L. \& Deriabin, Peter S. 1992. The Spy Who Saved the World: How a Soviet Colonel Changed the Course of the Cold War. New York: C. Scribner's Sons.

Sedikides, Constantine \& Wildschut, Tim \& Arndt, Jamie \& Routledge, Clay 2008. Nostalgia: Past, Present, and Future. Current Directions in Psychological Science, Vol. 17, No. 5, pp. 304-307. http://dx.doi.org/10.1111/j.1467-8721.2008.00595.x.

Skulte, Ilva 2016. Introduction. Framing the Future in the Past: Challenges for Memory Politics in the Baltics. In: Igors Gubenko \& Deniss Hanovs \& Vladislavs 
Malahovskis (eds.) The New Heroes - The Old Victims: Politics of Memory in Russia and the Baltics. Riga: Zinātne, pp. 8-15.

Truc, Gérôme 2011. Memory of Places and Places of Memory: for a Halbwachsian SocioEthnography of Collective Memory. International Social Science Journal, Vol. 62, No. 203-204, pp. 147-159. DOI:10.1111/j.1468-2451.2011.01800.x.

Upmalis, Ilgonis \& Tilgass, Ēriks \& Dinevičs, Jānis \& Gorbunovs, Anatolijs 2006.

Latvija - PSRS karabāze. 1939-1998: materiāli un dokumenti par Padomju armijas atrašanos Latvijā un tās izvešanu. [Latvia - the USSR Military Base. 1939-1998: Materials and Documents on the Presence of the Soviet Army in Latvia and Its Withdrawal.] Riga: Zelta grauds.

Ziemele, Ineta (ed.) 2001. Mazākumtautību (minoritāšu) integrācijas aspekti Latvijāa. [Aspects of Integration of Minorities in Latvia.] Riga: Latvian University.

Zvirgzdin̦š, Indulis 2003. Laiku un saimnieku maiṇa 'Patmalniekos'. [Change of Time and Owners in 'Patmalnieki'.] Stars, September 2.

\section{INTERNET SOURCES}

Centrālās statistikas 2011 = Centrālās statistikas pārvaldes datubāzes. [Central Statistical Database.] Available at http://data.csb.gov.lv/pxweb/lv/tautassk_11/ tautassk_11_tsk2011/TSG11-06.px/table/tableViewLayout2/?rxid=6b213b07c02d-49b7-badb-3d7ced80fdff, last accessed on September 25, 2017.

Commission of Historians. Available at http://www.president.lv/pk/content/?cat_id=7; last accessed on September 25, 2017.

Forumavia.ru. Available at http://www.forumavia.ru, last accessed on September 25, 2017.

Law on Land Reform in Rural Areas of the Republic of Latvia. Available at http://likumi. lv/doc.php?id=72849, last accessed on September 25, 2017.

Mārciena: Skaiți un fakti. [Mārciena: Figures and Facts.] Available at http://www. marciena.lv/turisms-marciena/skaitli-un-fakti; last accessed on September 25, 2017.

Mārcienas pagasta uzñēmumi. [Mārciena Sustainable Enterprises.] Available athttp://www. marciena.lv/marcienas-pagasta-uznemumi; last accessed on September 25, 2017.

Odnoklasniki.ru. Available at https://ok.ru/, last accessed on September 25, 2017.

Odnopolchane.net. Available at http://www.odnopolchane.net/, last accessed on September 25, 2017.

Photographic Memories. Available at https://fotki.yandex.ru/users/bir4onok/album/174326, last accessed on September 25, 2017.

Spa hotel Mārcienas muiža. Available at http://www.marciena.eu/index.php/en/we/ history, last accessed on September 25, 2017.

Tūrisms Mārcienā. [Tourism in Mārciena.] Available at http://www.marciena.lv/turismsmarciena, last accessed on September 25, 2017.

Valsts aizsargājamo kultūras piemineklu saraksts. [List of State-Protected Cultural Monuments.] Available at http://likumi.lv/doc.php?id=50976, last accessed on September 25, 2017.

Video memories: Rekviem po gorodkam gde my sluzhili. [Requiem to the Cities Where We Served.] http://notebookvideo.ru/1h-gKvhZd8/rekviem_po_gorodkam_gde_ my_sluzhili.html, no longer available.

Zeltini. Available at http://www.vietas.lv/eng/objekts/bijusa_psrs_strateiska_kodolrakesu_ baze_pie_zeltiniem/, last accessed on October 4, 2017. 


\title{
VALUES, SUBSTANTIALITY, AND PASSAGE OF TIME: REPRESENTATIONS AND REINTERPRETATIONS OF MILITARY HERITAGE
}

\author{
Dagnostaw Demski \\ Institute of Archaeology and Ethnology \\ Polish Academy of Sciences, Poland \\ e-mail:d.demski2@gmail.com
}

\begin{abstract}
The article examines the subject of post-Soviet military bases in Poland, and deals with two main issues: 1) presenting such sites as entanglements of place, materiality, military and symbolic elements in the process of creating commonality, and 2) regarding them as products of local "imaginings" and external touristic expectations. I look at how ways of constructing heritage are shaped and constructed through locals' encounters with tourism. Following this, I claim that the defining criteria of what can be regarded as heritage relevant to accompanying transformations of original functions of military sites or post-Soviet military bases involve value, substantiality, and the passage of time. To elaborate on these research questions, I draw on data from two places where the Soviet Army was deployed: Borne Sulinowo, along with Kłomino, and Międzyrzecz, with Kęszyca Leśna. The differences in size, function, and proximity to bigger cities are factors that helped to determine the distinct ways in which the local people dealt with the Soviet military presence, and how the foreign military past can be used in the process of handling different types of tourists, those interested in nature, often well-preserved near the former military space, those interested in history and those following the trail of military issues (e.g. fortresses, bunkers, and fortifications). The sites for local inhabitants are where they live, for tourists they are places to see, and for some people they can be interesting spaces to set up military camps or fortresses.
\end{abstract}

Keywords: Cold War, entanglement, military heritage, Poland, post-Soviet military base, transformation, tourism 
The camp is the diagram of a power that acts by means of general visibility. For a long time, this model of the camp, or at least its underlying principle, was found in urban development, in the construction of working class housing estates, hospitals, asylums, prisons, schools: the spatial 'nesting' of hierarchized surveillance.

The principle was one of 'embedding' (encastrement). The camp was to the rather shameful art of surveillance what the dark room was to the great science of optics.

(Foucault, cited in Rabinow 1984: 19) ${ }^{1}$

In the eyes of contemporary Poles, post-Cold War military bases date back to relatively recent times, although over twenty years have passed since 1993, when the final withdrawal of the Russian Federation military forces from Poland took place. The last Russian soldiers left Poland on September 18, 1993, and this paper was written at the end of $2016 .^{2}$

In the memories of Poles and in the mainstream public discourse, this element of history of Soviet forces stationed in Poland seems to be unpopular, and if it appears at all, it appears more in debates of historians or in a regional or local context, namely in the areas where the troops were located. For a long time, the main topic in Polish narratives about the past was the period of World War II, but in the late 2000s the socialist period of the Polish People's Republic (1945-1989) became popular. This was a sign of changes in memory. New plots, themes, and narratives appeared, and this interest in the socialist period in Poland may indicate a new stage of collective memory, adding new meanings to the view of this period. Examples of this are a number of exhibitions held in Warsaw. In 2000 the first big exhibition dedicated to the socialist time, Szare w kolorze 1956-1970: Kultura okresu gomutkowskiego (Grey in colour, 1956-1970: Culture of Gomulka's period), was held in the Zachęta Gallery of Contemporary Art in Warsaw. The exposition included actors wellknown from popular socialist films playing their former roles in the gallery. This event attracted a large number of visitors and can be regarded as the first indication, at least in Warsaw, of growing interest in this aspect of the past of Poland. Later on, two exhibitions were held at the National Museum, Rzeczy pospolite, polskie wyroby 1899-1999 (Common wealth, Polish products 1899-1999) (Frejlich 2001), with a focus on the socialist time, and Chcemy być nowocześni: Polski design 1955-1968 (We want to be modern: Polish design 1955-1968) (Kiełczewska 2011). These exhibitions and the number of visitors they attracted may indicate that the socialist past had become relevant and an 
object of reflection in Poland. This was a new form of reflection for a generation which did not remember the socialist past well. In my opinion, in line with the prevailing interest in the period of socialism, there was also a growing interest in a variety of life expressions, from everyday life to politics, including the issue of the former Soviet military bases.

The Cold War military bases were located near places inhabited by civilians: towns and cities of various sizes, as well as villages. In this connection, by post-Cold War military bases I mean former military zones that have been adapted by local authorities and residents as places with material (buildings and ruins) and intangible (remembrance) remnants of the old military bases.

When discussing Soviet bases, it should be noted that military bases in general are a specific phenomenon with common characteristics that go beyond particular armies, periods, and politics. In general, foreign military bases occupy transitory spaces: firstly, in the understanding of their locations on routes that were strategic from the military perspective and, secondly, in the sense of being inhabited only for a short period of military service. Often, the same buildings and infrastructure served the next regime and its armies when political or military changes occurred.

In central and eastern Poland, the Soviet Army was almost invisible. ${ }^{3}$ For numerous reasons, not much was written on the subject of the Northern Group of Forces of the Soviet Army (NGF SA) just after their departure and, if at all, they were mentioned in very general terms: from a distance, so to speak. The majority of Polish inhabitants had no direct experience of encounters with Soviet soldiers, and the few contacts mostly involved the inhabitants of the western territories, close to the East German border. ${ }^{4}$

The proximity of a military base ${ }^{5}$ provided these civilians with knowledge of a certain type of reality and offered an opportunity for an encounter, for interaction, for the occurrence of a personal experience. This foreign military neighbourhood in relation to the adjacent civilian districts had both an official and public character, and an unofficial, local or private quality. ${ }^{6}$ While most of the ordinary citizens may have never encountered Soviet soldiers, in the local experience and memory knowledge of the bases was also present in the narration of space, in abandoned buildings and deserted grounds. The material remains testified to the recent presence of foreign military troops, but also offered traces of an older pre-Cold War past, perhaps marginal, yet still real. People who arrived there and settled in the deserted areas discovered "the closed, old spaces" anew: old barracks or garrison ruins, military motifs, and the surrounding nature.

Interviews with residents of towns located near the former military bases suggest that these topics belong mainly to the memory of local inhabitants. 
Since 2015, I have visited former military bases and facilities in Poland (Borne Sulinowo, Kłomino, Międzyrzecz, and Kęszyca Leśna) and Latvia (Karosta, Daugavpils cietoksnis, Mangal̦sala, Krustpils, Mārciena, Alūksne and Zeltiṇi). These visits made it possible for me to examine several cases, which provided the opportunity for comparative research. In this article, I focus on only selected Polish cases to distinguish differences within Poland: Borne Sulinowo, along with Kłomino, a small, currently abandoned settlement in the nearby forest that was built by the Soviet Army, and Międzyrzecz, with Kęszyca Leśna, ${ }^{7}$ on the outskirts of this city. Borne Sulinowo, with Kłomino, and Międzyrzecz, with Kęszyca Leśna, are comparable examples of former military spaces, differing only in size. While Borne Sulinowo (more than 4,000 inhabitants) and Kłomino were closed to civilians as was Kęszyca Leśna, locals and the military lived side by side in Międzyrzecz (approx. 20,000 inhabitants). Drawing on interviews and informal conversations with local inhabitants, I aim to show the opportunities offered through a comparison of different spaces.

I use the notions "space", "place", and "site". Most scholars refer to space as a physical location, while place refers to a more specifically designated part of space, the way in which humans intentionally and collectively change their environment, and how their surroundings shape local communities (see, e.g., Agnew 1987). I understand site as both a space and place, where space is an area, a terrain, while a place has a connection with imagination and specialisation. In other words, a place is associated with an action, with making a place. A military space indicates a zone intended for military activities, but as a postmilitary space, it shows an area designed for transformation and adaptation to local needs of both internal development and tourist expectations.

The starting point is place in the sense of a locality embracing military past or collective identity. Zbigniew Bokszański (2008: 68) has stated that the formation and persistence of a community is, to a large extent, a function of objective conditions (natural, economic, threats, etc.). The experience is no longer subjective and is transformed into objective facts when it is shared by many people for a long time (ibid.).

To discuss the military past, I use the notions "heritage" and "legacy". The distinction between the two seems clear, but it is complicated depending on the point of view. When we look at it from the point of view of the state, heritage and legacy are sometimes used in tandem, where heritage is something that is valued and celebrated, and legacy something that is there, but uncomfortable and denied rather than emphasised. However, if we look at it from the local point of view, legacy is regarded not as negative but as neutral: as something that remains of the past, in the sense of tradition and acceptance. Unlike at the state level, the choices at the local level appear to be more practical than ideological. 
Discussing sites with Soviet post-military bases, I am mainly interested in place as a particular binding physical ground, memory, and identity in the local context. Physical ground has different meanings, both for people living there for generations and for new settlers. Its image and ways of appropriating it are important in the construction of a place through different memories, as well as in the form of an embodied local collective identity. However, as Maria Mendel, when discussing inhabitants of post-war Gdańsk, has said (2010: 374 ), local places are no longer physical rooting points; they are increasingly abstract places, constructed and conceptualised areas. This phenomenon seems to be present in the case of areas included in post-Cold War bases. I ask in this article whether there is an attempt to preserve the past or, on the contrary, as Mendel said, "the local inhabitants are trying to maintain a balance between the abstract, dematerialised nature of these sites and their persisting despite materiality linked to the physical territory and material objects, which are carriers of remembrance found there" (ibid.).

I will discuss how the military character of the recent Cold War past influences the construction of contemporary identity and locality. I argue that the ways of constructing heritage depend on the level - either state or local - thus enhancing the question of what is acceptable from these opposite points of view. Thus I posit the question of whether former Soviet military bases can be considered to be cultural heritage.

\section{MILITARY LEGACY OR HERITAGE}

Recent decades have seen the concept of heritage undergo a profound change. Having at one time referred exclusively to the monumental remains of cultures, heritage as a concept has gradually come to include new categories, such as intangible and industrial heritage. ${ }^{8}$ This concept in our time, accordingly, is an open one, reflecting living culture every bit as much as past culture.

The issue of cultural heritage has several aspects. First of all, there is the problem of what is considered heritage and on the basis of what parameters we should classify a given space, landscape or object - tangible or intangible as part of heritage. To understand whether and what military remains can be considered cultural or national heritage, let us consider the scientific definitions of heritage.

Various aspects of cultural heritage are reflected in the extensive literature on the topic, from the classic distinction between heritage and history - preserved objects that validate memories (Lowenthal 1998 [1996]) - to postmodern authors' ideas: the past is a cultural construct and authentic ancient sites and 
objects are products of a culturally conditioned evaluation of the past (Holtorf 2001), and heritage is created in a process of categorising (Carman 2002: 22). In another definition, heritage is not only a product of the present time, but also of a long process of relating history, through which communities recognise themselves precisely as communities (Matthews 2006: 87). The focus on contemporary experience is stressed by another definition, as both non-material elements of culture, passed down from generation to generation, and material elements, such as buildings, memorials, monuments, and other objects, including archive records, are seen to form experiences to which communities refer when they construct their here and now (Albert 2007: 50). Heritage covers everything that contemporaries select from the past that they themselves have created for the use of the present or in order to pass on to their descendants (Ashworth \& Graham \& Tunbridge 2007: 32), representing history and archaeology.

Industrial heritage is comprised of the remains of industrial culture, which have historical, technological, social, architectonic or scientific value. It includes buildings and machines, workshops, manufacturing plants and factories, ... warehouses and storehouses, locations where energy is generated, transmitted or used, transport and its infrastructure... military techniques of defence and attack.... (Affelt 2009: 5-6)

Military heritage classified as industrial has to be regarded as a specific part of the past.

It is worth noting who makes what decisions about the choice and assignation of the category of heritage to a given object or place. From the scientific point of view, the defining criteria mostly involve value, substantiality, and the passage of time (Kobyliński 2009). An object or a place is prominent due to being a vehicle of certain values for human culture, most frequently understood as connected with the culture of the subject that determines the criteria, and thus a nation, a group, a local community, etc. Value may be of historical, social, symbolic, economic or other character. Substantiality denotes the preservation of a certain permanence of form, mostly material, which may be usable. The passage of time indicates the value of permanent artefacts that were made in the past or are no longer made, and whose financial (and other) value increases over time (e.g. works of art).

These factors - value, substantiality, and passage of time - also come into play when discussing post-Cold War military bases. Put briefly, the former Soviet military bases have no symbolic, social or historical value because from a contemporary state perspective they belonged to occupiers. Many of them are still standing, especially those that were located on top of former German buildings and fortifications. A quarter of a century seems to be too short 
a period to determine their more universal value, but in the case of older preSoviet barracks and constructions on military bases, the substantiality or the material space and buildings from the previous era meet the general criteria. Such questions are taken into account ${ }^{9}$ on the state and professional scholarly levels, where opinions help to determine official classification.

Before I move on to the issue of selection, it is important to distinguish the nature of the concept of values. Following Edmund Małachowicz (2007), the main dilemma is whether values are permanent properties of things, or exist objectively, outside things, and are attributed to things depending on the needs and predilections of their users or knowledgeable subjects. There are two distinct views. According to axiological objectivism, values are constant, although they may be unrecognised. However, according to axiological subjectivism, values change depending on time, place, and circumstances in terms of how they are attributed to objects by their users. Accepting one of these extreme views results in practical consequences. If values are objective and constant, the objects or phenomena that carry them require absolute protection. If they are relativised to place, social circle or historical demand, their obligatory character for the individuals and institutions responsible for them is weakened.

The cases of former military bases show that values are not constant: they are attributed from outside and correspond to the needs of contemporary and historical politics. Choices made and categories attributed reflect a certain way of thinking about the past or its fragments, and their evaluation from the perspective of contemporary needs. The inclusion - selection - of military bases in the category of cultural heritage in Poland faces various obstacles:

- the objects fulfilled political functions, which may be treated as a value, but they were symbolically alien from the point of view of the state, nationally and politically, i.e., subject to the rules of a foreign state;

- it appears that they have no ability to create and sustain a sense of apparent identification and social bond with contemporary people;

- even if they constitute the oldest (the first) objects of, for instance, architecture in these regions, as they sometimes do in the western territories, they do not represent continuity within the contemporary Polish culture;

- the traditional Polish distrust and caution regarding Germans and/or Soviets, embodied in historical politics on the state level.

The problem is that the places and objects functioning as former Soviet military bases from the period of the Cold War did not belong to the continuity of the Polish state and culture. Most of them were located in the former barracks and buildings constructed in the 1930s by Nazi Germany or earlier, at the turn of the twentieth century; some of them even occupied entire areas or districts that 
were separated from cities. They form a legacy left there by the then (or later) enemies, which is impossible to remember, and impossible to erase completely from memory. They may find use only as a result of the transformation of their original functions (unless they are used as barracks by the Polish military forces, as in an increasing number of cases), when tourism arrives, bringing new bodies that animate places with new imagery and expectations.

The factors discussed - value, substantiality, and passage of time - can also be considered in the context of a foreign symbolism and changing attitude towards the past, where foreign symbolism was treated negatively. In this connection, the figure of the foreign soldier as part of Polish history deserves a closer look. As a rule, it is associated with the loss of independence, partitions, occupations, and World Wars I and II. It is associated with loss and defeat. ${ }^{10}$ Many Poles served in foreign armies due to conscription (by Germany, Russia, and Austro-Hungary), but there is also the tradition of mercenaries, which has not been widely discussed. Poles also served in American, British, and French armies, as well as with Turkish troops (in the Russo-Turkish War). Both the presence of foreign uniforms ${ }^{11}$ and Poles wearing foreign uniforms are historically common phenomena. The Polish uniform emerged in this context as a symbol of a glorious past; it symbolises sacrifice but it is also associated with hope for the future.

Another point is the historical differentiation of the territory of Poland. As was mentioned above, Soviet military bases were located in the western part of Poland, which means that there is no tradition regarding these bases in relatively recent Polish history; in this sense, there is no collective memory, and no state or national continuity. The central, southern, and eastern parts of Poland vary, having a variety of connections to Polish history, including big or small military issues. They offer different understandings of local spaces, as communal spaces are recreated in the present through the view of the longer history.

The presence of Soviet troops thus forms part of a broader discussion of foreign armies and uniforms, but this is a subject for a separate study. PostSoviet military bases were a vestige of World War II, a continuation of the division of powers, yet in a new form - that of the Cold War. It was not a simple continuation, however, as it resulted from the end of another war. The division of powers, similarly to the national affiliation of numerous military bases, changed after World War II.

To recap, the motif of the presence of foreign military forces, of foreign uniforms, has repeatedly occurred in the history of Poland and does not make it possible to consider these places as heritage or to use their remains, with their accumulated symbolism. Often, people have lived in the shadow of a fortress 
for a long time, but almost every generation encounters another army and different uniforms.

Heritage is a product of contemporary times, of a culturally, socially or even politically conditioned evaluation of the remains of the past. ${ }^{12}$ The goals for such an evaluation are formulated centrally, e.g., by the state, but also at the local level. In consequence, it is necessary to stress that appropriating a site, remains, and local people is a continuous and changeable process. The symbolic value factor determines that the post-Soviet military bases cannot be seen as cultural heritage on the national or institutional level.

The local level represents another perspective, especially after an encounter with tourism, which provides "another poetics" (Crouch 2008 [2002]: 210). Inhabitants and visitors see local history through traces of the past in buildings, the layout of old streets, ruins, monuments, and military objects on a base. A variety of interactions enable them to see, touch, feel, and discuss features of the former military landscape, and thereby sense it as a place through intermingling and communicating with what was left at the place.

Architectural objects, old and new, the layout of a place and buildings of remembrance constitute the space in which the local community forms. If the postCold War military bases are not national heritage, what should be done with them? It depends on the local community. The main buildings not considered to be heritage because of the lack of connections with the history of the country and the nation can still be used for touristic purposes. A local community can take advantage of the military aspect, other elements of the military landscape, and the presence of foreign uniforms to place itself in the circle of military interests in a universal sense, and not only in the sense of local history. What is not recognised as national heritage may still be of interest to specific tourists who are not interested in the sides of conflicts, victims and persecutors, losers and winners, but in the military past and related matters. Tourism emerges as a new factor shaping local space into a new context, thereby "enlivened and endowed with meaning through the practices of the tourists" (Massey 1994).

\section{MILITARY MARKET AND A MODEL OF MILITARY SPACE}

As David Chaney (2008 [2002]: 200) put it, "tourists are regarded as consumers of public places of the other cultures", just like in all of the cities of Poland, which have opened up to tourism, exposing the landscape, architecture, past or nature, depending on the resources available. This also applies to sites with former military bases. 
Objects related to everyday military activity in the form of manoeuvres and training (e.g. bases, barracks, and training grounds), or objects connected with military activity (e.g. battlegrounds) belong to the category of military objects. Marie-Louise Sørensen and Dacia Viejo-Rose (2015: 1) call them places created as a result of wars, conflicts, and their aftermaths. The material traces, remnants of the memories of people living in the area, are subject to individual interpretation. At this point, however, I am focusing on military tradition not as traces but more in terms of thinking and acting, or lifestyle. These are part of military tourism, a sphere closely tied to the issue of heritage.

If tourism makes places exhibited (Coleman \& Crang 2008 [2002]), what can we say about the former military places? This kind of military heritage seems to be relevant for analysis because "different products for quite different markets can be created from the same raw material by varying the interpretation process" (Ashworth \& Haan 1986). We can thus speak of a "military market" or areas of military interest. These are formed in response to specific needs and are shaped to meet the requirements of a specific group of visitors and users interested in military themes generally as part of a longer tradition. In this sense, tourists are interested in both the contemporary remains and the past functioning of the bases themselves. As was mentioned above, in the territory of Poland the Soviet Army was mostly housed in military buildings built earlier, mainly by the Germans. Some were constructed before World War $\mathrm{I}^{13}$ and others were built in the 1930s. ${ }^{14}$ For example, Kęszyca Leśna, near Międzyrzecz, was built entirely atop German military structures. These topics were discussed in interviews and conversations conducted in the field, leading me to conclude that for fans of military tourism the contemporary situation seems not to be very important; they are interested in military remains, architecture, and the layout of places.

Borne Sulinowo offers great attractions due to the fact that the town grew entirely within the boundaries of an old military base built by Germans and used by Russians. In Miedzyrzecz, the Soviet Army occupied the buildings of former German bases in the city and a smaller base in Kęszyca. Military structures, especially in Borne Sulinowo and to a lesser extent in Kęszyca Leśna, therefore were parts of closed military areas. For fans of military matters, they are also interesting because they resemble many other military structures of this type, built in the 1930s. This opens up another dimension, a world of major military structures, and for tourists it offers yet another military model.

In local communities, the tourism factor offers a new framework within which local inhabitants' contact with guests arriving in their space affects the forms of existence. Following David Crouch (2008 [2002]: 207), it could be argued that space becomes a peculiar medium, meaning that in the face of experiencing 
the same space by two different groups (locals and tourists), after a new space is perceived, objects and artefacts valued as belonging to the local space and landscape slowly become objects participating in a consumption process. As a military model, this space is seen not as a post-Cold War base in Poland, but as belonging to the military concept of a series of citadels, battlefields, and fortresses, and in this sense to the category of military thought and military practice. This kind of military practice can be observed or researched in Borne Sulinowo, mainly through the template spatial plan and architecture. This is not possible in the case of Miedzyrzecz, where barracks were located in the city amidst civilian buildings.

Michel Foucault included the contemporary military tradition in the wider category of an Enlightenment trend based on discipline and order in "the form in which military discipline, political power, and religious authority are usually exercised" (Rabinow 1984: 36). Bases existed in the past but they also exist today. ${ }^{15}$ Like barracks, they formed good soldiers. Both types of military objects constituted places where soldiers were gathered, in garrisons and barracks, in their own territory, whereas military bases were associated with gathering centres, military training, and separation from the local population in a foreign territory.

Often, when we visit a certain place, we see changes, some of which have resulted from the needs of the inhabitants and others from the expectations of tourists. Tourists bring different imagery and experience. Crouch (2008 [2002]: 208) writes that a tourism site is a "field of action predicated by its representations". Tourists often come with images of the sites in mind, created by promotional sources, and what is left for tourists is a "reading of representation" (ibid.). Also in military places they construct knowledge through engagement, as the tourist practice consists of experiencing, sensing, and walking. The life of a military base turned into an attraction can be observed in Borne Sulinowo, where the site is represented for tourists through public relations and advertisements.

Miedzyrzecz exhibits historical themes: a castle, an old town, churches and monuments, and in the museum there is the historical continuity of this land with the Slavic and Polish past. Borne Sulinowo as a small town entirely constructed on top of the old base exhibits military infrastructure, buildings, a polygon, and the surrounding nature, underlining the context of the military aura. Both offer different sensations of space.

Sites of this kind are products of both local "imaginings" and external touristic expectations. In this sense, tourism has generative power at the sites, "eroding innate and specific values of places" (Relph 1976). Some of the former ordinary cities and towns with military pasts have been transformed to satisfy the expectations of tourists. Tourist trips entail the production of standardised experiences for newcomers. 


\section{LOCAL ORAL TRADITIONS DURING AND AFTER THE COLD WAR}

The Cold War is illustrated for tourism as buildings, signs, monuments, training-grounds, and barracks. However, tourism as a practice is not just about viewing, but also about storytelling, creating symbolic sites, and exhibiting objects and data in local museums, which can be observed in Borne Sulinowo and Międzyrzecz.

In contrast to World War II, there was no large-scale fighting directly between the two sides during the Cold War, although there were major regional wars, known as proxy wars, supported by the two sides. The Cold War split the wartime alliance against Nazi Germany. Although the two superpowers never engaged directly in full-scale armed combat, they were heavily armed in preparation for a possible all-out nuclear world war. Apart from the development of nuclear arsenals, and the deployment of conventional military forces, the struggle for dominance was expressed via proxy wars around the globe, psychological warfare, massive propaganda campaigns and espionage, rivalry at sports events, and technological competitions, such as the Space Race.

In general, the Cold War and its events have left a legacy that is often reflected in popular culture, especially in the media, featuring themes of espionage and the threat of nuclear warfare. ${ }^{16}$ On the state level, the Soviet Union sought to dominate the internal affairs of countries. The Soviet Union set up secret forces loyal to Moscow, and local communist rulers took control of the media, then banned all independent civic institutions.

Unlike "hot war", with its large numbers of victims, the Cold War imposed specific frameworks that had little effect on the local population. The presence of foreign soldiers could be associated by locals more with mutual individual benefit than with a wider threat. ${ }^{17}$ Interviews with the early inhabitants of Borne Sulinowo show that they had not heard of close contacts with senior Soviet officers, but they told stories confirming contacts with lower ranking soldiers, mainly consisting of buying fuel or goods available only on the bases. The presence of the Soviet soldiers was officially rigidly ideologically controlled, but on the local level there were contacts; officers had contacts with Polish Army representatives, and low ranking soldiers had contacts with the local people.

For propaganda reasons, during the socialist period images of foreign soldiers on the bases, incompatible with the official guidelines, were not shown. Narratives of this type appeared either in jokes or in the anecdotes of the inhabitants in the areas near the former bases. In accounts of military bases, the classic division of us/them was applied, although the tone of the narratives was not necessarily hostile: on the contrary, it often indicated mutual informal relation- 
ships and dependencies. When access to the bases was forbidden, there was a "miraculous renaissance of the oral tradition" (Bloch 2008: 300). In the past, the taboo subjects in tales about the bases included such issues as the soldiers' attitudes, the military incompetence of the commanders, malfeasance, conservatism, ignoring of information and poor administration. After the withdrawal of the foreign troops, these subjects came to the foreground; there are examples in the local newspaper Moreny: Gazeta Krainy Jezior i Lasów (Moreny: The Paper of the Land of Lakes and Forests), published in Borne Sulinowo since 1993.

\section{POST-MILITARY LOCALITY OR VARIOUS FORMS OF ENTANGLEMENT}

The post-Cold War landscape emerged in Poland in the 1990s. There are various views regarding it and there are a number of representations and contested interpretations of the past (for a longer discussion on this issue, see Demski \& Czarnecka 2015 and Czarnecka 2015b). A landscape is a patch of land that has some sort of socially created unity as a result of the behaviours of people who act within it, or the meanings they ascribe to it, or both (cf. Hirsch \& O'Hanlon 1995). Cultural activity leaves traces - deliberately or inadvertently - on the landscape, with subsequent cultural activity that transforms it, especially in connection with tourists' expectations. The information contained in advertising and promotional materials created for tourists is not recognised and applied by locals. The image of the socialist past is more complicated.

Remembrance of the distant past does not change much, although it is subject to reinterpretation. I believe that in Poland the memory of World War II is a kind of model, a pattern of speaking about the war. In this context, memories of the Cold War period are subject to more pronounced changes. Perhaps we are still more in the phase of the memory of individual witnesses than in the phase of creating a collective memory through the tools of official memory politics. ${ }^{18}$

Apart from changes brought about by tourism, we are witnesses of something else: the transformation of what was remembered and what will be remembered, to some extent differently in state and local communities' memory politics, making choices alongside various social, historical, and economic trends and achieving different goals. This involves the near past, and its description is difficult because we do not know what the final outcome of these transformations will be.

Frequently, the remaining inhabitants, witnesses of the Soviet Army presence, focus on other threads than do those who had no direct involvement with those events. The difference is associated with the fact that histories have personal and emotional characteristics, and places evoke memories of concrete 
events and interactions. For descendants or readers from afar, many of these emotions, images, and experiences are not significant: a distant picture, a kind of synthesis is enough for them. Some memories or experiences will survive in family lore; they will remain as family stories which contradict official interpretations but, being quite personal, will not spread outside of the family.

The former Soviet bases, such as Borne Sulinowo and Kęszyca Leśna, became living spaces for locals. Events, situations, and experiences either remain in memory or are captured/preserved in the form of photographic frames. Live situations, social interactions, mutual relations during meetings with other people, personal experiences and impressions resulting from them, collective and individual experiences - all of these contributed to the everyday life of the former inhabitants of the place, and today are the last remaining witnesses of those events. What remains? Stories told by witnesses, second-hand reports, and accounts by their children or acquaintances, partly written down in interviews from those years, partly in memoirs, sometimes in unpublished personal journals.

In the stories about the Soviet military, told by contemporary inhabitants, information from multiple sources dominates. These memories and images are conveyed via novels, interviews, articles, reports, other literature, photographs, museums as institutions that preserve memory, public debates and exhibitions, and the main motifs include pioneering, experienced traumas, familiarisation of space, its reclaiming, making choices, and attributing credibility to the choices of one's parents and grandparents.

The cases of Borne Sulinowo and Miedzyrzecz differ greatly, as the former has a totally new population, and the latter has preserved the continuity of the majority of Polish population since the 1950s. The memories of the pioneers shaped the process of reclaiming the post-Soviet base, forming contacts with the base, cooperating, and getting to know the other side. Originally, the memories of the other side, of the soldiers who left, were insignificant. Nowadays, when the presence of new inhabitants in the territory has been established, the subject of the military past attracts increasing interest. As attempts to transgress their own context, we can regard the narratives as those of pioneers, the founders of a dynasty, everything made anew, becoming familiar with the space, houses, and domestic situation. As this period matures for musealisation, we have to remember that for the local inhabitants the subject still has strong resonance in the present.

In this phase, a desire to fill the "blank pages" in the local history may emerge, to widen the discussion of whom they notice from that period. The educational function and the function of commemorating what was there are developing. As interviews conducted in Borne Sulinowo showed, the soldiers' 
plight is not of interest to the local population; rather, they focus on the fate of the common people.

Writing about the ways of presenting World War II, Bartosz Korzeniewski (2015: 119) remarked on the idea of "giving back face", in the sense of individual identity, to the war victims in the museums of martyrdom located in former places of torment, i.e., former concentration camps. On the former bases, no one gives back face except for a former photographer of the Soviet Army and occasional events. In Borne Sulinowo, there is a permanent exhibition of photographs from the German and Soviet times on the walls that separate the town from the training ground; special tours are organised for German tourists, etc. Nevertheless, a number of photographs remain in private collections both in Międzyrzecz and Borne Sulinowo.

The changes are related to the way in which this past and inhabitants' experiences are interpreted. The time has come to tell the history through the eyes of witnesses who remember it and through participants' accounts of individual experiences. The cases of abandoned bases, where there are only buildings left in ruins, are examples of a landscape that nobody cares about for various reasons. Some are abandoned because they lie far from the main routes (e.g. Kłomino), reflecting the weight of the economic concern. Moreover, the abandoned sites have no social significance for contemporary people, and no political or historical functions.

The military aspects of the bases still remain in the foreground for locals, but this is even truer for tourists (in Borne Sulinowo, not in Mieddzyrzecz), and the connections of the military forces with the area are not officially emphasised on the local level. Today I would say that what matters to tourists ${ }^{19}$ are the torn down walls, the architecture, found artefacts, the history of familiarisation, old photographs, uniforms, paramilitary objects and objects for sale, as well as events organised for them. The numbers and names of the victims of the camps, the names of the dead who are buried in the cemeteries, the training ground, the wild space and nature preserved due to the existence of closed-off, former military places remain blank pages.

If the power of the military camp as a place acts upon people through its visibility, which Foucault understood as controlling (Rabinow 1984), then tourists come to see, to feel, and sometimes to experience this type of control, most often in terms of what is obscure and informal, and what cannot be considered heritage in the institutional sense. Places that have been preserved almost entirely on the plan of the military camp, such as Borne Sulinowo, are examples of this. Miedzyrzecz, as a larger city, has a wider tourist appeal (a castle, old tenement houses, the old layout of streets, museums, spas, cafes, and discos). And for this reason, in spite of the Soviet Army's being stationed there, today the city is not associated with military tourism. 
If there is nothing to praise, or to be proud of, are the former military bases things we need to know about? Do they have any potential iconic visibility as real estate? Whether these places are just "heritage of war" or are places that participate in the recovery and remaking of communities (Sørensen \& ViejoRose 2015: 1) depends on the interpretation of the past, and interpretations other than the official version of the past - local or regional versions - are a part of this process. Differences occur at the crossroads of state and institutional policy (e.g., regarding a museum) and the contacts of the local population with the tourists visiting the bases.

Post-Soviet military bases as the remains of the Cold War refer to places of frozen conflicts, where a new phase of open conflict cannot be excluded. Frozen conflicts are those in which violence has ceased, along with the presence of military bases, but where there is a lack of resolutions that have been generally accepted, however reluctantly. This implies that at least one of the parties feels that issues have been left unresolved, including perceived ongoing injustices. ${ }^{20}$ In frozen conflicts, one or more parties often tend to cultivate narratives about the other as the enemy. These frozen conflicts tend to come about when a new order is imposed by actors who do not tolerate the continuation of the conflict. When it is not possible to resolve a dispute, it is moved into the background and remains "stuck" there, in a space that is neither officially discussed nor spoken about on a daily basis.

The withdrawal of armed forces from Central and Eastern Europe was heralded as the conclusion of conflicts over post-military bases and their aftermaths. Recent events have demonstrated that this is not necessarily so, ${ }^{21}$ and that the usefulness of these spaces did not end with the passing of the previous period.

\section{CONCLUSION}

Former Soviet military bases were, at least in part, areas closed off or inaccessible, and frequently unmarked on official maps. Despite their invisibility, they certainly were places distinctive due to the contrasts (military character, foreign jurisdiction, different culture, etc.) with the local population. They became emblems and measures of the Cold War era on more than the regional level, were always present in the minds of the inhabitants, and after the withdrawal of the Soviet Army were staged for tourists.

At least some of the former military bases disappeared. They disappeared faster than the monuments connected with the Soviet Army, although the monuments only served a symbolic function (Czarnecka 2015a). On the other hand, if the bases find other uses, they are preserved in a material sense. ${ }^{22}$ 
Sites disappear when the material parts crumble, memory loses its former function, and people's sense of a place turns in a new direction. However, it is not possible to totally erase the Cold War past. Contemporary residents remain rooted in both tangible legacy and material objects. This provides a sense of commonality entangled with the physicality of the place, the past circulating through local memories, regional institutions, and the ability to use legacy to develop the place for inhabitants and for tourists.

The compelling charm of the past makes it possible to state that the Cold War lives on, not in its real form but in the form of a lesson, entertainment or knowledge, fragmentary but fitted to the needs of the inhabitants and visitors to the area. The post-military bases are used as both the means of remembering a particular past and a medium for education, knowledge or - in a changed form - entertainment. What can be done with the bases?

The former post-Cold War military bases are a part of a past that is still difficult to deal with. They have not found places on the national heritage lists. Yet, some of the bases have been adapted and presented as local heritage, as is the case in Borne Sulinowo. New narratives, not necessarily coherent, show that these places are not always marked by the state as heritage valued, but that they have valuable stories to tell. Although not by the state, they are "invested places" owned by local communities or noticed by some external communities. Examples are the German tourists who visit the former bases, and the events which are organised there. The bases are present in the recollections of former soldiers (German or Soviet) whose fate was connected to these places.

Since these places still exist, shaped by the entanglement of materiality with changing imagination, who could invent (in the sense of Anderson's imagined communities (Anderson 1991 [1983])) the post-Cold War military bases and why have they not been invented yet? Tourism has the power to revitalise these sites, but can anything besides tourism revitalise them? In my opinion, the image of the past is subject to change, and this is determined by the passage of time and the values professed. In this sense, the next generations will invent new interpretations similar to the exhibitions of socialism in the museums mentioned at the beginning of this article.

This process depends on the passage of time. Almost twenty-five years after the withdrawal of the Soviet Army is a short period in the scale of history. Events of the Cold War in the areas surrounding Borne Sulinowo and Międzyrzecz are still remembered by their witnesses, who ascribe particular meanings to them. When, with the passage of time and the change of generations, the memories of individuals lose their significance, this period of the past will gain a new resonance and other factors will influence the future evaluation of the postSoviet military bases. 
To paraphrase the words of Marc Bloch (2008: 220) that the "ideological" character of war has lent so much beauty to sacrifice, from the contemporary point of view it can be stated that even the "ideological" character of the Cold War lent a dramatic quality to the experiences of the local population, while it also lent glory to service in the proximity of the Cold War front-line. In any event, thanks to the stories which have been told by locals and tourists - often contradictory and frequently "ideologically" spruced up - these places, located between the known and the unknown, have gained new expression in contemporary Poland.

\section{NOTES}

1 This article is based on the formulas of Michael Foucault presented in the collection edited by Paul Rabinow (1984). All references to Foucault are from Rabinow 1984.

${ }^{2}$ I discuss cases of the post-Soviet military legacy in Poland till the end of 2016; further developments related to the new government of Poland have not been taken into consideration.

3 Among the exceptions were Łowicz, Warszawa-Rembertów, Torun, and Września, not as military bases, but as military units.

${ }^{4}$ With regard to figures and geographical data on the subject of post-Soviet bases in Poland, see Czarnecka in the present issue.

5 In the cases in which the bases covered parts of towns - Legnica, Kołobrzeg, Międzyrzecz, Szczecinek, Białogard, and others - the contiguity had a more pronounced character.

6 Such conclusions can be drawn from interviews conducted in Borne Sulinowo (2015 and 2016) and Międzyrzecz (2016).

7 The system of military fortifications extends in the vicinity of Miedzyrzecz, and was known as the "Strengthened Arc of the Oder and Warta Rivers" (Ostwall or Festungsfront im Oder-Warthe Bogen). It was created by the Nazi Germans between 1934 and 1944 to protect the eastern border. There are dominant fortification structures, which in the vicinity of Międzyrzecz include military objects situated in the small settlements from Kursko through Kęszyca Leśna, and Pniewo to Boryszyn.

8 The Convention for the Safeguarding of Intangible Cultural Heritage is a UNESCO treaty adopted by the UNESCO General Conference on October 17, 2003. For more scientific discussions, see Lowenthal 1985, Hoffman 2006, Sandis 2014, and Falser 2015 .

9 In books discussing the heritage in a more general manner (Kobyliński 2009), there are no direct references to the question of the Soviet post-military remains. It seems that, from the point of view of the central government, it is a question of military use and re-use of the objects and, if this is not possible, then the issues are left in the hands of local authorities. 
${ }^{10}$ In broader terms, this is more or less a common figure in the context of Central and Eastern Europe, between Russia, Germany, and Turkey before World War I, where soldiers of different local origins served in the imperial armies.

${ }^{11}$ In the eyes of a defeated nation, the uniforms symbolise not only sacrifices on battlefields but also former and maybe future glory (Bloch 2008: 86).

12 The change in historical politics under the new government of 2016/2017 confirms that the approach to the past is a political matter.

${ }^{13}$ For example, the Boyen stronghold, constructed in Giżycko in the 1850s (Festung Boyen, Lötzen).

${ }^{14}$ For more on the subject of the history of the base at Borne Sulinowo, see Demski \& Czarnecka 2015, and Czarnecka 2015b.

${ }^{15}$ Bases also form spaces with developed defense systems. Usually they are surrounded by fences, and in order to get inside it is necessary to pass through control systems at the gates. Bases form separate complexes or even towns (as, for instance, in the case of Bagram in Afghanistan) with military and training facilities, but also with churches, discos, shops, etc. At present (2016), Russia is setting up bases in Syria, e.g. near Palmyra.

${ }^{16}$ For more on this, see the relevant chapters in Demski \& Laineste \& BaranieckaOlszewska 2015.

${ }^{17}$ Unlike the protests in Poznań in 1956, where the Soviet Army was on the alert.

${ }^{18}$ For more on memory politics viewed by a historian, an ethnologist, and a sociologist, see Dudek 2000, Korzeniewski 2010, and Szpociński 2015, respectively.

19 This statement draws on interviews with inhabitants of Borne Sulinowo, especially with those who were and are engaged in creating a place for tourists (e.g. organisers of the yearly Summer Military Vehicle Meeting), as well as on conversations with tourists visiting the town.

20 This interpretation of former military bases in the light of current Russia-Poland/ Europe relationships has been common since 2016 .

${ }^{21}$ At the beginning of 2017, American armed forces were being stationed at the postSoviet base in Żagań (western Poland), and at other military sites.

${ }^{22}$ My discussion does not include situations in which bases are used for military purposes. This is a subject for a separate study. 


\section{REFERENCES}

Affelt, Waldemar 2009. Dziedzictwo techniki, jego różnorodność i wartości. [The Heritage of Technology, Its Diversity, and Value.] Kurier Konserwatorski, Vol. 5, pp. 5-20. Available at http://www.nid.pl/upload/iblock/858/85811d0a0b216dd273cefb36ee a5d6e1.pdf, last accessed on November 23, 2017.

Agnew, John A. 1987. Place and Politics: The Geographical Mediation of State and Society. London: Allen \& Unwin.

Albert, Marie-Theres 2007. Kultura, dziedzictwo, tożsamość. [Culture, Heritage and Identity.] In: Monika A. Murzyn \& Jacek Purchla (eds.) Dziedzictwo kulturowe w XXI wieku: Szanse i wyzwania. Kraków: Międzynarodowe Centrum Kultury, pp. 49-56.

Anderson, Benedict R. 1991 [1983]. Imagined Communities: Reflections on the Origin and Spread of Nationalism. New York: Verso.

Ashworth, Gregory J. \& Haan, Theo Z. de 1986. Uses and Users of the Tourist-Historic City. Veldstudies, Vol. 10. Groningen: Geografisch Instituut Rijksuniversiteit Groningen.

Ashworth, Gregory J. \& Graham, Brian \& Tunbridge, John E. 2007. Pluralising Pasts: Heritage, Identity and Place in Multicultural Societies. Chicago: The University of Chicago Press.

Bloch, Marc 2008. Dziwna klęska. [Strange Disaster.] Warszawa: Oficyna Naukowa.

Bokszański, Zbigniew 2008. Tożsamości zbiorowe. [Collective Identities.] Warszawa: Wydawnictwo Naukowe PWN.

Carman, John 2002. Archaeology and Heritage: An Introduction. Leicester: Continuum.

Chaney, David 2008 [2002]. The Power of Metaphors in Tourism Theory. In: Simon Coleman \& Mike Crang (eds.) Tourism: Between Place and Performance. New York \& Oxford: Berghahn Books, pp. 192-206.

Coleman, Simon \& Crang, Mike (eds.) 2008 [2002]. Tourism: Between Place and Performance. New York \& Oxford: Berghahn Books.

Crouch, David 2008 [2002]. Surrounded by Place: Embodied Encounters. In: Simon Coleman \& Mike Crang (eds.) Tourism: Between Place and Performance. New York \& Oxford: Berghahn Books, pp. 207-218.

Czarnecka, Dominika 2015a. "Pomniki wdzięczności” Armii Czerwonej w Polsce Ludowej i III Rzeczypospolitej. [Monuments of Gratitude to the Red Army in People's Poland and the Third Republic of Poland.] Warszawa: Wydawnictwo Instytutu Pamięci Narodowej.

Czarnecka, Dominika 2015b. Making Sense of the Past: (Re)constructing the Local Memorial Landscape in a Post-Soviet Base in Poland. Journal of Ethnology and Folkloristics, Vol. 9, No. 2, pp. 21-40. Available at http://www.jef.ee/index.php/ journal/article/view/204, last accessed on November 23, 2017.

Demski, Dagnosław \& Czarnecka, Dominika 2015. Mapping Meanings in the Post-Soviet Landscape of Borne Sulinowo. Latvijas Vēstures Institūta Žurnāls, No. 2 (95), pp. 96-120. Available at http://www.lvi.lv/lv/LVIZ_2015_files/2numurs/D_ Demski_D_Czarnecka_Mapping_LVIZ_2015_2.pdf, last accessed on November 23, 2017. 
Demski, Dagnosław \& Laineste, Liisi \& Baraniecka-Olszewska Kamila (eds.) 2015. War Matters: Constructing Images of the Other (1930s to 1950s). Budapest: L'Harmattan.

Dudek, Antoni 2000. Ślady PeeReLu: Ludzie, wydarzenia, mechanizmy. [Traces of the People of the Republic of Poland: People, Events, Mechanisms.] Kraków: ARCANA.

Falser, Michael 2015. Cultural Heritage as Civilizing Mission: From Decay to Recovery. Heidelberg \& New York: Springer.

Frejlich, Czesława (ed.) 2001. Rzeczy pospolite: Polskie wyroby 1899-1999. [Common Wealth: Polish Products 1899-1999.] Olszanica: Bosz.

Hirsch, Eric \& O'Hanlon, Michael (eds.) 1995. The Anthropology of Landscape: Perspectives on Place and Space. Oxford: Clarendon Press.

Hoffman, Barbara T. (ed.) 2006. Art and Cultural Heritage: Law, Policy, and Practice. Cambridge \& New York \& Melbourne \& Madrid \& Cape Town \& Singapore \& São Paulo: Cambridge University Press.

Holtorf, Cornelius J. 2001. Is the Past a Non-Renewable Resource? In: Robert Layton \& Peter G. Stone \& Julian Thomas (eds.) Destruction and Conservation of Cultural Property. London: Routledge, pp. 286-294.

Kiełczewska, Anna (ed.) 2011. Chcemy być nowocześni: Polski design 1955-1968 z kolekcji Muzeum Narodowego w Warszawie. [We Want to Be Modern: Polish Design 19551968 from the Collection of the National Museum in Warsaw.] Warsaw: Muzeum Narodowe w Warszawie.

Kobyliński, Zbigniew 2009. Własność dziedzictwa kulturowego: Idee - Problemy Kontrowersje. [Ownership of Cultural Heritage: Ideas - Problems - Conflicts.] Warszawa: IAE PAN.

Korzeniewski, Bartosz 2010. Transformacja pamięci: Przewartościowania $w$ pamięci przesztości a wybrane aspekty funkcjonowania dyskursu publicznego o przeszłości $w$ Polsce po 1989 roku. [Transformation of Memory: Revaluations in the Memory of the Past and Selected Aspects of the Functioning of the Public Discourse about the Past in Poland after 1989.] Poznań: Wydawnictwo Poznańskiego Towarzystwa Przyjaciół Nauk.

Korzeniewski, Bartosz 2015. Przemiany obrazu drugiej wojny światowej w polskich muzeach po roku 1989. [The Transformation of the Image of World War II in Polish Museums after 1989.] In: Jerzy Kałążny \& Amelia Korzeniewska \& Bartosz Korzeniewski (eds.) Druga wojna światowa w pamięci kulturowej $w$ Polsce i w Niemczech: 70 lat później (1945-2015). [World War II in Cultural Memory in Poland and Germany: Seventy Years Later (1945-2015).] Gdańsk: Muzeum II Wojny Światowej, pp. 105-138.

Lowenthal, David 1985. The Past is a Foreign Country. New York: Cambridge University Press.

Lowenthal, David 1998 [1996]. The Heritage Crusade and the Spoils of History. Cambridge: Cambridge University Press.

Małachowicz, Edmund 2007. Konserwacja i rewaloryzacja architektury w środowisku kulturowym. [Preservation and Regeneration of Architecture in a Cultural Environment.] Wrocław: Oficyna Wydawnicza Politechniki Wrocławskiej. 
Massey, Doreen 1994. Space, Place and Gender. St. Paul: Minnesota University Press. Matthews, Christopher N. 2006. The Idea of the Site: History, Heritage, and Locality in Community Archaeology. In: Ludomir R. Lozny (ed.) Landscapes Under Pressure: Theory and Practice of Cultural Heritage Research and Preservation. New York: Springer, pp. 75-91.

Mendel, Maria 2010. Tożsamość zbiorowa jako lokalność. [Collective Identity as a Locality.] In: Maria Mendel \& Alicja Zbierzchowska (eds.) Tożsamość gdańszczan: Budowanie na (nie)pamięci. [Identity of the Inhabitants of Gdańsk: Building on (Non)Memory.] Gdańsk: Wydawnictwo Uniwersytetu Gdańskiego, pp. 371-395.

Rabinow, Paul (ed.) 1984. The Foucault Reader. New York: Pantheon Books. Available at https://monoskop.org/images/f/f6/Rabinow_Paul_ed_The_Foucault_Reader_1984. pdf, last accessed on November 24, 2017.

Relph, Edward 1976. Place and Placeless. London: Pion.

Sandis, Constantine (ed.) 2014. Cultural Heritage Ethics: Between Theory and Practice. Cambridge: Open Book Publishers.

Sørensen, Marie, L. S. \& Viejo-Rose, Dacia 2015. War and Cultural Heritage: Biographies of Place. Cambridge: Cambridge University Press.

Szpociński, Andrzej 2015. Polityka historyczna PRL-u w latach 1945-1985: Studium przypadku. [Historical Policy of the Polish People's Republic in the Years 19451985: Case Study.] In: Izabela Skórzyńska \& Dorota Skotarczak \& Stanisław Jankowiak (eds.) Społeczeństwo PRL 2: Kultura. Pamięć. Poznań: Instytut Historii UAM, pp. 203-214. 


\title{
FROM THE BORDERLAND OF THE IRON CURTAIN TO EUROPEAN AND WORLD CULTURAL HERITAGE
}

\author{
Melinda Harlov-Csortán \\ Atelier Department of European Social Sciences and Historiography \\ Eötvös Loránd University \\ Budapest, Hungary \\ e-mail:mharlov@yahoo.com
}

\begin{abstract}
Due to its location at the edge of the Iron Curtain, a constant military presence existed between today's Hungary and Austria from 1949 to 1989. The northern section of this territory is today a transnational nature park and an economically prosperous area. Most of the information materials, either on site or in publications, cover in detail the end of the military presence and reveal much less about the actual events, failed missions, and negative consequences during that almost half-century. This paper investigates this transformation by focusing on image creation between 1989, when a split appeared in the Iron Curtain in the researched territory, and 2015, when this event received international acknowledgement and appraisal in the form of the European Heritage Label. The focus is on the territory of the north-western borderland of Hungary, which became a transnational world heritage cultural landscape in 2001. The article concentrates on the social engineering processes involved in emphasising certain memories and neglecting others during the heritagisation process.
\end{abstract}

Keywords: cultural landscape, Hungary, heritagisation, Iron Curtain, memory, post-Cold War, tourism

In the sunset of dissolution, everything is illuminated by the aura of nostalgia, even the guillotine.

(Kundera 2009 [1984]: 2)

The Iron Curtain ran along the entire border (established after World War I) of Hungary and Austria in the west (356 kilometres) and after 1950 on the southern border between Hungary and Yugoslavia (627 kilometres) (Jobst 2013). It 
even split in two a lake, called Fertó or Neusiedlersee, in the north-western corner of contemporary Hungary. The area around the lake has marvellous flora and fauna, with jewellery-box-like small towns. The closeness of the economically more prosperous Austria and of the entertaining and touristy Lake Fertô/ Neusiedlersee made this part of the country tempting to settle or to establish a business after the political change in 1989. The researched landscape has earned regional, continental, and world recognition through the establishment of a transnational nature park in the early 1990s, and has received numerous awards for its environmental protection activities, gaining World Heritage status from UNESCO (2001) and the European Heritage Label by the European Council (2015). The following research discusses how this drastic change in the evaluation and characteristics of the area from a militarised, almost harsh territory to a peak region of the country happened, and what kind of memorialisation practices took place during the last approximately quarter century (Fig. 1).

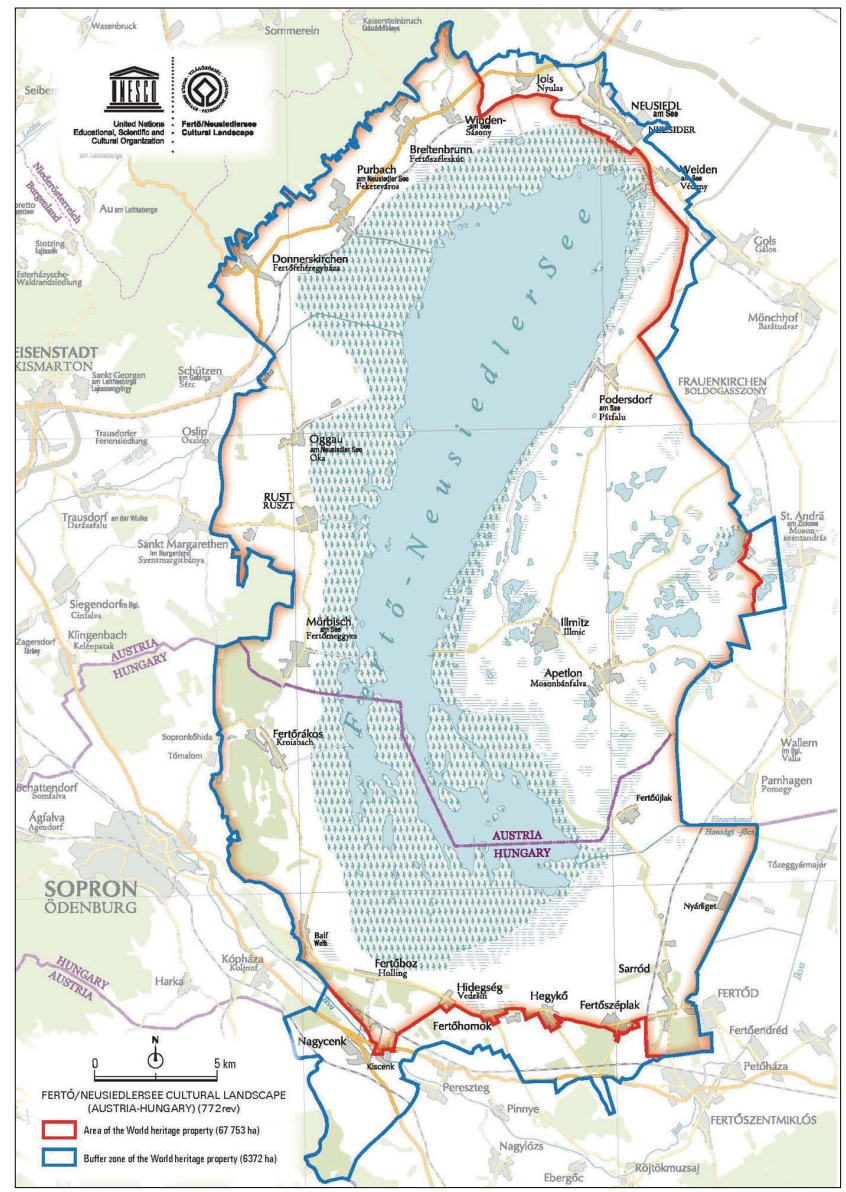

Figure 1. Map of the Fertó Cultural Landscape. Official site of the UNESCO World Heritage sites in Hungary (http:/ / www.vilagorokseg. hu / fertoneusiedlerseecultural-landscape). 
First, a theoretical overview explains the views and approaches to memory, memory object and place as well as the heritagisation process along with actors who have played an important role in the presented case study. This literature review also looks into some of the former representative cases that specifically deal with the heritagisation of the socialist past, with some Eastern and Central European examples. Secondly, the border zone period of the Cold War past is introduced by focusing on the local communities, the military units and their lives. The next part of the paper, in three sections, discusses the transformation period. The first section introduces the accomplished heritagisation processes in the researched area. Those mainly tangible reminiscences from the distant past have already been acknowledged, researched and managed as important and valuable for contemporary and future generations. The second section analyses the handful of examples that commemorate the Cold War period in the territory covered by the case study. They are very different from each other in terms of owners, format, and message, and each covers a very narrow segment or defined interpretation of that half-century. The last section points out those aspects of the Cold War period that defined the researched area and still influence it but have been overlooked in the heritagisation processes. Among others, these include the everyday life, achievements, and hardships of the local communities. The concluding subchapter reviews the most important findings and points in the article.

As methodology, instead of a descriptive chronological approach an integrated analysis was undertaken. Both theoretical and literary research were carried out, and interviews were conducted with diverse actors. The location of the research was both in the capital of Hungary, where most archival materials are available, and on site, in the Fertó/Neusiedlersee area. An interdisciplinary and comparative research approach was chosen, which takes into account the different actors' diverse economic, emotional, and political opportunities and standpoints, among others. This approach enabled the complexity of the heritagisation process in the researched area to be explored.

\section{COLLECTIVE MEMORY AND PLACE: HERITAGISATION OF THE COLD WAR PERIOD}

Even though memory, in contrast with imagination, is supposed to communicate the truth of the past, there are personal, communal, circumstantial, and other factors that transform or modify memory (Keszei 2015: 14). Hence, neither a person's own nor collective memory should be understood as a clear, oneto-one copy of the past (Schacter \& Scott \& Peggy 2011: 469). Barry Schwartz 
and his colleagues (Schwartz et al. 1986: 150) emphasised the "commemorative narrative" feature of collective memory, which they defined as a story about a significant historical event that has been re-crafted many times in order to convey the envisaged moral lesson. Along these lines, it is important to mention that even though collective memory contains less information and fewer details than community members' personal memories, it has a greater impact on transforming both personal memories and the officially narrated memory of the past (Brown \& Kuori \& Hirst 2012: 2).

The materialised examples of collective memory, such as memory sites, construct a narrative about the past by contributing to its ideologisation and hierarchisation. They have the main task of exemplifying and informing the community about its interconnectedness and uniqueness (Hirst \& Manier 2008: 186). However, any place, in its complex material, symbolic and narrative aspects, also contains elements of earlier inhabitants, such as power relations, value systems, and identities. In this sense, all places carry memories due to their connections to former human experiences (Connerton 2011: 84). ${ }^{1}$ Focusing on these aspects, the understanding of a place in social studies has been enriched by adding the human perceiver aspect. It is analysed how people construct and consume locations (Lefebvre 1991: 38-43). Place is no longer considered a neutral area, but it can define actual events realised there, and the possible social activities or use of that place, based on its social perception, which refers to the memories carried by the location. In case of memorials, they say much more about the people who erected them and the contemporary evaluation of the represented past (Pótó 1989: 79) than about the particular event in the past.

Nowadays, heritagisation is one of the most common realisations of this cautious management, when a memory of the past is identified, selected, and preserved in such a way that it is maintained in everyday life and for the benefit of the contemporary community. Preserving and managing a place lead to a possible change in its perception from an unacknowledged element of the past to an active part of the social, economic, and cultural revitalisation of the present. On the other hand, many times during heritagisation changes in material objects or their configuration take place, for instance, in order to serve the needs and desires of contemporary visitors. Similarly, the general view that one can re-establish the status and conditions of a chosen time period can disturb the complexity of a place. Such drastic modifications can often happen at the time of a major social or political transformation, which often leads to a reinterpretation of the past that better serves the contemporary (political) structure and roles, and, accordingly, they also have significance with regard to the future. 
It is important to mention that diverse social units take part in memorialisation or heritagisation. Political leaders who often use memories for their own purposes (Whelan 2005: 62) unquestionably participate in the formation process. By organising celebrations for the public commemoration or cherishing a given section of the past, collaborative agreement is meant to be expressed about the narrative of the given location. Similarly, economically influential characters can define the form, material, and management of a memorial. Professionals, participants/witnesses of the given period and those who own some material remnants from the given time/event can also define the narration based on their knowledge or experience. Accordingly, not just the given memory can be complex, but so can the targeted audience, as well as the memory entrepreneurs.

After the collapse of the Iron Curtain, in an attempt to reverse decades of isolationism, many post-Soviet states resorted to the idea of the West as a terrain of renewed belonging. Katherine Verdery (1999: 35) pointed out that the post-socialist transformation involved "a reordering of people's entire meaningful worlds" and this open-ended process entailed rewriting history, forming new political arenas, and rearranging physical places. Even though many experts see the necessity of a symbolic break with the previous system, even in the form of destroying monuments or rearranging locations (Lisiak 2010), some historians (Bik 2014) have noted that these are only the first steps in changing an ideological orientation. Thus, the process of de-Sovietisation is not limited to destruction or rearrangement. Moreover, after conflicted memory sites (a term used by Sharon Macdonald 2008: 1-5) are destroyed, it might be more difficult to reconcile with the past (Jampol 2014). With the elimination of tangible memories, not only possible historical data get erased, but, and more importantly, the narrative expressed by these heritage elements and their possible effects on the society evaporate, eliminating the possibility of researching and understanding them.

Eastern European countries had different memories of the communist past (Todorova \& Dimou \& Troebst 2014: 150) due to the different historical events within the individual countries and their relations to the Soviet Union. For instance, in Hungary, between the 1960s and 1980s, a less autocratic and oppressive system operated (partly in order to prevent another revolution after 1956). That is shown in the frequently used expressions for the country: the "happiest barrack", "gulyás communism", and "fridge socialism". Memories of the last part of the Cold War period in Hungary ${ }^{2}$ were not as negative as in many other countries, such as Ukraine and the Baltic states. ${ }^{3}$ Therefore, in Eastern European countries the particular meanings attached to communism vary. For the last twenty-five years, researchers of the socialist past have faced the difficulty of evaluating that period: what should be conserved, maintained, and supported. ${ }^{4}$ 
In Hungary the fifty years of the socialist past is not seen as unquestionably positive; hence, there is a very limited heritagisation regarding that period. The focus is on the uprisings and resistance, and not on the everyday life or the local participation in the oppressive system. The events of 1956, when Hungarians rose up against the Soviet power, and 1989, when the democratic changes happened, were and are symbolically linked to each other. They are seen as decisive moments in Hungarian history, when people had to defend the sovereignty and territorial integrity of their country. The contemporary power structure (today, just like in 1989) underscores these links between the 1956 revolution and the present day, leaving out all other aspects and periods of Hungarian history in the second half of the twentieth century (Eörsi 2009: 60-62). The following sub-chapter describes a study of this transformation that happened in north-western Hungary. It was a seemingly peaceful process with universal and international acknowledgement and appraisal, but still with "grey areas" and question marks regarding the future consequences of contemporary heritage management, such as the consequences of not exploring but overshadowing the socialist past by concentrating on other historical time periods. Would the memory of the researched area have a gap in terms of local level experiences of both historical moments and daily life?

\section{HISTORICAL OVERVIEW OF THE BORDER ZONE PAST}

The Fertó/Neusiedlersee area was not a border zone before the Treaty of Trianon, which concluded World War I in 1920, as the boundary between Austria and Hungary was located much further to the west and did not have the same significance during the united Habsburg Empire period (Fig. 2). Accordingly, the border zone experience was still quite new in 1949, when the "death zone", with a fence, land mines, and a constant military presence was established, making tangible the ideological segregation of the continent. While life was supposed to continue as before, this area was almost closed off from its surroundings in every direction. All visitors were checked and monitored and more than thirty settlements, including Brennbergbánya and Óhermes, located in between the actual state border and the military zone, became dead-end villages segregated from the world.

In this area both Hungarian and Soviet soldiers ${ }^{5}$ and military camps existed from the end of World War II onwards. Even though Hungary regained its sovereignty in 1947, due to the second paragraph of the twenty-second article in the fourth part of the Peace Treaty, the Soviet Union was allowed to keep its forces in the country to ensure transit between the Soviet-controlled section 


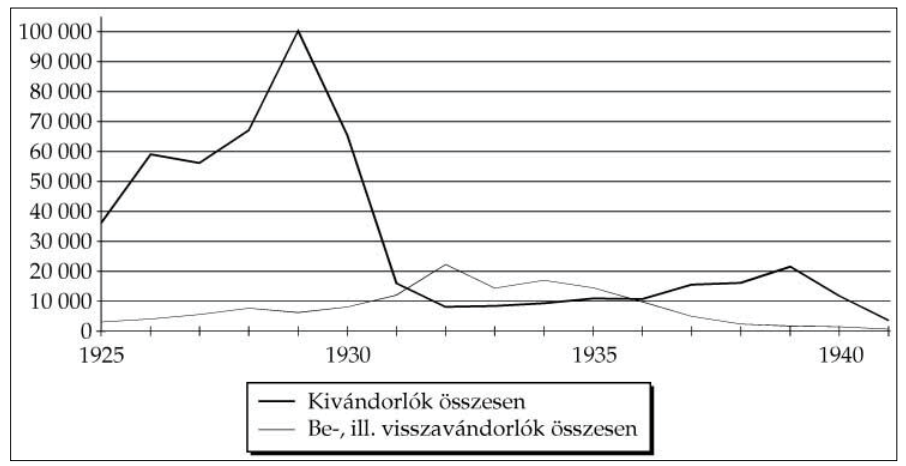

Figure 2. Annual population change and peaks thereof in Hungary in 1925-1940. The bold line shows the total number of migrants and the thin line the population change (Tarsoly 1997).

of Austria and the Soviet Union, and to do so without any defined limitation. ${ }^{6}$ Accordingly, Soviet military units occupied the already existing military locations that, ironically, had often been used by German forces. The Soviet forces located in Hungary rarely interfered in local or regional events or even with the population. They stayed in closed military camps, mainly preparing themselves for Western intervention and not for local control. Their equipment was accordingly not as high-quality or numerous. Based on original footage, their armoured cars and aeroplanes in Hungary were the ones that had been replaced in other occupied countries, such as Czechoslovakia, because they were old or obsolete (Molnár 1996: 36-46).

Austria regained its independent status in 1955; hence, the Soviet military units were supposed to leave not only that country but Hungary as well, because there was no longer a need to support transit between Austria and the Soviet Union. However, the Warsaw Pact was signed almost at the same time, which ensured the opportunity to keep Soviet forces in the member states to guarantee mutual military cooperation and assistance. After the 1956 revolution this situation changed briefly, when conditions in the country and its status were uncertain. At that time significant solidarity and collaboration among the public and some border guards made the Iron Curtain a bit porous. Right after the end of the revolution (until April 1957) 150,000-200,000 people escaped from the country through the area under study (Sallai 2012: 42). However, a new Hungarian-Soviet agreement regarding the details of the Soviet military units in Hungary was signed in 1957, with many parts of it open to further agreements, which gave relative freedom of action to the incoming Soviet troops. During the four years of cruel punishment for the revolution 
more people were prosecuted and killed than during the actual fights, and an even more rigid border control was established (Tóth \& Bank 2006). Everyday life and agricultural activities were affected by the border zone reality. Many territorial restrictions were introduced, and new technical equipment (such as more watchtowers and bombs) and more soldiers (mainly young soldiers from other parts of the country) were assigned to the border area. Fatal shooting of innocent fishermen happened regularly on Lake Fertó and nearby rivers. Fruit gardens and vineyards were destroyed by weed-killing chemicals spread by the wind from the border area (Zsiga 1999: 70-78).

The Soviet units from Austria mainly moved to the border area of Hungary, which immensely increased the size of the Soviet military presence in the area under study. The placement was quite hectic at this stage. The new Soviet military units were placed in former working camps and agricultural buildings, or the local Hungarian soldiers were moved out of their bases to accommodate the Soviet "newcomers". Even though the number of Soviet soldiers increased, they still did not interfere with the local communities. Following the plan, they were the back-up unit for a possible Western attack: Austria was considered sympathetic to the Western forces and was hence seen as a possible enemy. The type of equipment and number of Soviet troops did not enable them to act as military police forces in Hungary (Baráth 2013). Mainly trained soldiers were stationed in Hungary, whose task was to maintain the status of the equipment in case of a sudden attack. Accordingly, they rarely left their local bases.

In 1965, the "death zone" was replaced with an electronic signal system that stayed in place until 1989. The system provided electronically transmitted sound to border guards and there were spotlights to detect anyone or anything crossing the border. It did not hurt trespassers and was hence called the "gentle Iron Curtain". Even though this version of border protection caused significantly less tragedy in comparison to actual fences and land mines, it still defined the outlook and the life of the region (Fig. 3). By the late 1980s, this system did not fulfil its function successfully, as there were numerous false alarms due to animal movements, and an increasing amount of successful border-crossings occurred. The improvement or repair of the system would have been too costly for the Hungarian state. Moreover, international events and the new aims of the Hungarian political leadership, as well as the inauguration of the "world passport" in 1988, which made it possible to travel abroad, made the strong military border control redundant (Sallai 2009: 1-53). Accordingly, the leadership of the country decided to eliminate the costly electronic system, but kept the military presence with the establishment of border crossing points. The Hungarian political change of 1989, its accession to the European Union (EU) in 2004, and then to the Schengen agreement in 2007, gradually led to smooth 


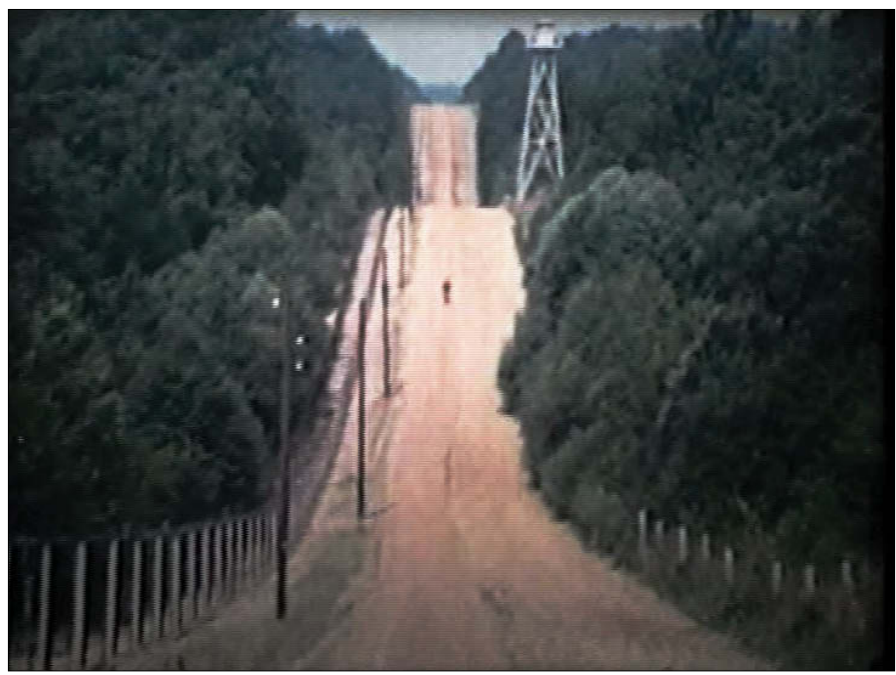

Figure 3. Hungarian Iron Curtain. Open Society Archive 394-0-1:15.

cooperation along the border. Nowadays Hungarians work daily in Austria, and Austrians have settled on the Hungarian side of the border. The area has become very popular and conditions are constantly improving for many reasons.

\section{ANALYSIS OF THE TRANSFORMATION IN THE RESEARCHED BORDER TERRITORY}

As Paul Connerton (2011: 84) explains, places incorporate former human experience and existence. The Fertô/Neusiedlersee area has also many "memorials" that allude to the previous human occupation of the territory. Diverse actors (such as locals, academic professionals, local governmental representatives, and for-profit organisations) have different ideas about what is worth protecting and propagating and what is not worthy of the heritagisation or museumisation processes. Firstly, this chapter critically introduces the pre-twentieth century elements of the past in the researched area, which are preserved in the collective memory, and then focuses on the memorialised aspects of the local Cold War experience, based on diverse actors, to emphasise the complexity of the existing memorialisation strategies. The last section discusses those elements of the Cold War period that still influence locals but for diverse reasons are not incorporated in the heritagisation process. 


\section{Memories preserved and glorified from the pre-Cold War period}

As early as ancient times, people left their marks on the researched area. Even today a Roman altarpiece exists on the contemporary Hungarian side of the border (Tóth 1971) and a trade route has been discovered in Austrian territory that historians have called the Amber Road (Navarro 1925). These archaeological findings have been researched since the 1930s and have been published widely in academic journals (see East 1932). These significant findings appeal not only to the academic community's interest, but have also been promoted by locals eager to attract tourists to the area, especially since 1989. As a result, the findings regularly appear in contemporary introductory texts about the region, published either by the local government (Wild 2000) or smaller businesses (Hárs 2000: 166). However, visitors have criticised the limited accessibility of these sites, and the lack of local directional signs and complementary services (for example, visitors' centres). ${ }^{7}$ These disadvantages decrease the potentials of memorialising the ancient past in the researched area.

One of the most prosperous periods of this region was in the eighteenth and nineteenth centuries, when significant landlords had estates in this area, which increased the value of the territory both economically and culturally. Among others, the Esterházy family ${ }^{8}$ had (and in Austria still has through their foundation) territories in this region from the Habsburg Empire period onwards. In today's Hungarian settlement called Fertôd, their "little Versailles", an architecturally outstanding estate, with a marvellous noble castle and with connected beautiful gardens, still stands. This "family centre" characterised the cultural (Joseph Haydn was an artist in residence) and economic life of the region (Gates-Coon 1994). Since 1989, the state monument protection agency has concentrated on some renovations in the researched region. A large amount of money (mainly from the state and in the last ten years partly from the EU) has been allocated to renovating the "little Versailles" (see Esterházy kastély) and the Széchenyi family's ${ }^{9}$ noble estate in Nagycenk (see Nagycenk), which are also part of the World Heritage area established in 2001. Following the investigation by William Hirst and David Manier (2008) of the uniting power of collective memory elements, both tangible heritage examples have also been nominated as official (national (Nagycenk in 2016) or historical (Fertôd in 2011)) memorial places as they "represent important Hungarian historical moments" (Nemzeti 2014). These investments have led to truly impressive results, as well as expensive entrance fees. On the other hand, there are numerous sites that carry similar or even greater significance (such as the Bishop's Palace in Fertórákos), but do not receive central state support, with no clear reason being given except for general statements of limited resources. ${ }^{10}$ Local cultural entities (such as regional museums or municipalities) are able to provide neither the necessary financial help nor any long-term management plans (Fig. 4 and 5). ${ }^{11}$ 


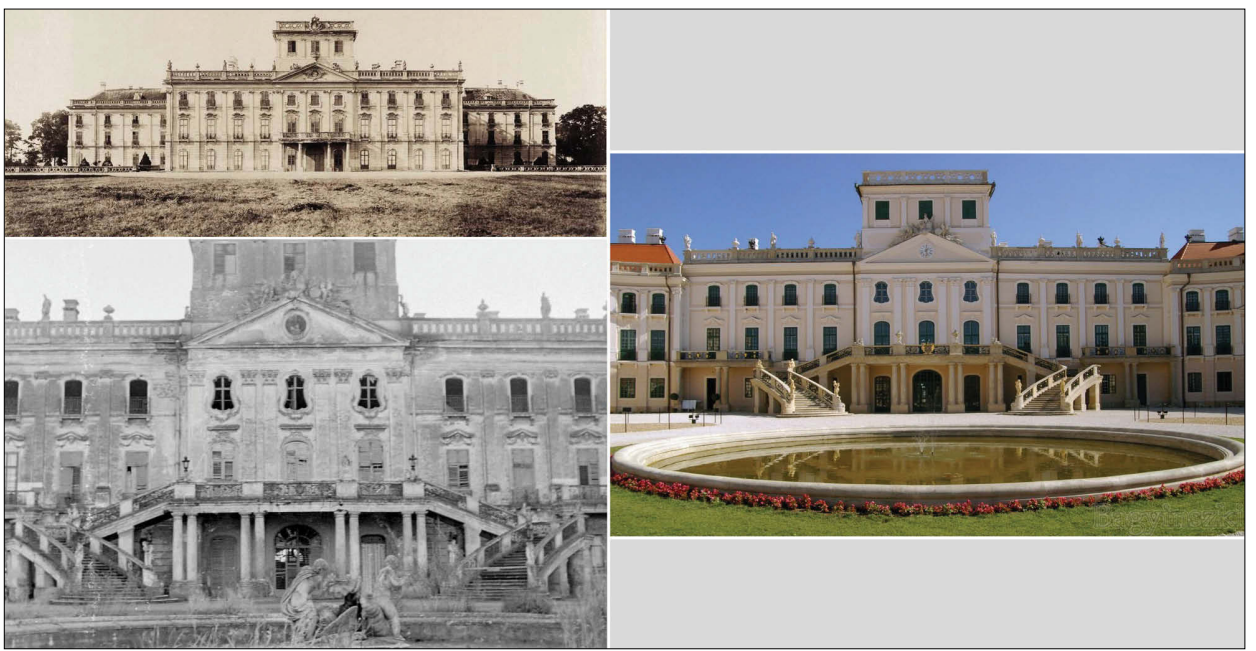

Figure 4. Monument protection on diverse levels: "little Versailles" in Fertód. Fortepan Online Photo Archive (http: / / fortepan.hu / ?view=all\&lang=en).

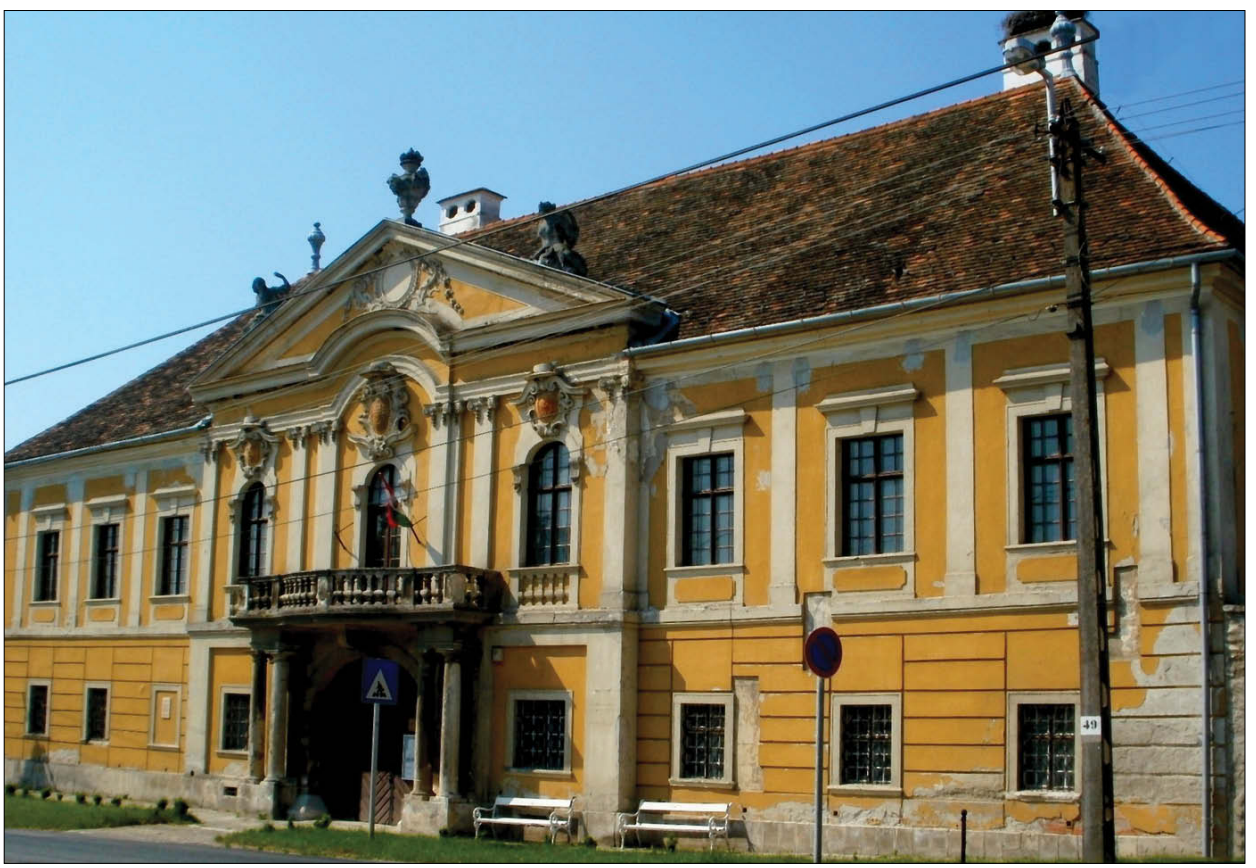

Figure 5. Bishop's Palace in Fertórákos (http:/ / www.fertorakosikirandulas.hu/fertorakos/kastely.html). 
Besides the archaeological findings and the noble tangible heritage, the vernacular architecture of the region has also been acknowledged by monument protectionist professionals since the first part of the twentieth century as monuments of the past. These buildings are seen as information sources not just regarding the given architecture, the settlement structure, the inhabitants and their lifestyles, but also regarding the cooperation among different nationalities. German-speaking minorities have been part of this region for centuries and their architecture forms a unique category that is neither Hungarian nor German/Austrian, but a special combination of the two (Fejérdy 1988). The interest of monument protection experts received political support in the Cold War period, as they were supposed to serve contemporary aims as well (Pótó 1989). Extensive and successful monument protection activities could be achieved by emphasising the political aim of exhibiting all of the positive effects of "the socialist way of life and direction" (Danubeparks Association 2000), rather than the academic and professional aims of protecting vernacular architectures typical of certain segments of the society. ${ }^{12}$ Unfortunately, there are only a handful of cases (such as in the settlements of Sarród and Fertószéplak) that have been renovated and operate as exhibition places of the local past, run by locals thanks to EU support. These would establish a role for the inhabitants in the memorialisation process, but the economic sustainability of these places and the strength of the inhabitants' voices are questionable due to the lack of proper management (Minorics 2012).

The border zone, with its settlements and, on their outskirts, the newlyerected, transformed or already existing military bases of both Hungarian and the less visible Soviet soldiers, was not just a territory to be highly protected, but also a region to show off. Accordingly, urban architecture protection also took place at its highest, national level in Sopron and Köszeg, two significant cities near the border. The restoration of Sopron's inner city was even awarded with the European Prize in 1975 (Fig. 6). These chosen "shop window" examples also became tourist destinations at the end and after the socialist period. Despite this, tourists (both national and foreign) face difficulties in exploring these sites. They have a hard time reaching these destinations, as neither public transportation nor the highways are of high quality. This is the most common concern regarding the researched area on popular social media sites and in tourism publications (such as Turista, a nature-exploring magazine). ${ }^{13}$ These problems originated in the misconception about the region in the 1990s that it was prosperous due to its closeness to the West, which was partly prevented by the lack of state funds for infrastructure support. ${ }^{14}$ 


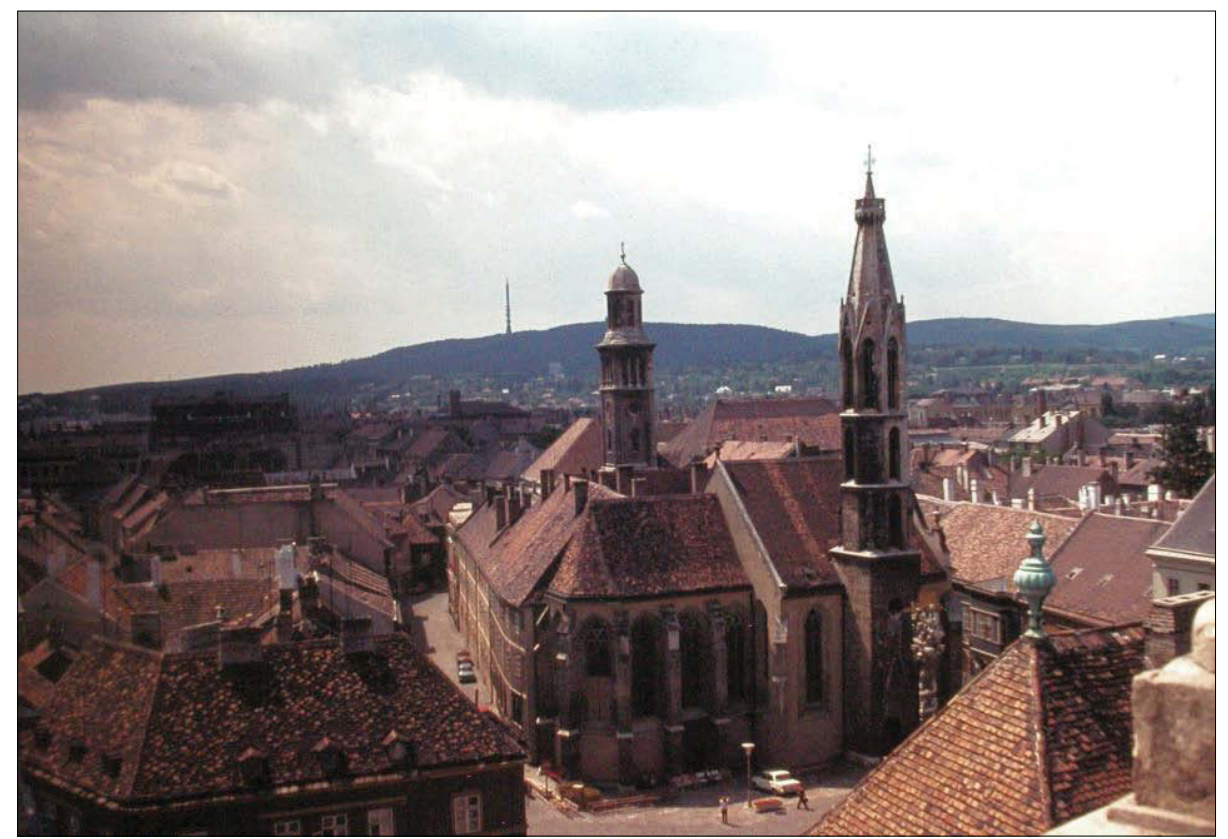

Figure 6. Sopron inner city in 1975. Fortepan Online Photo Archive ( http: / / fortepan. hu / ?view=all\&lang=en).

Despite the outstanding cultural and historical character of the researched region, it was and mainly still is an agricultural area. The connecting tangible and intangible memories of, for instance, gardening, wine-making, and fishing are significant elements of the current perception of the valuable past. Museums and tourist farms promote traditional activities among the general public, while these activities are also scientifically investigated for their sustainability and environment-protecting potentials. ${ }^{15}$ Besides fruit gardens and vineyards, the processing of reeds at Lake Fertô has been a continuous activity since the pre-World War II period. Moreover, it increased in quality and quantity during the Cold War period. Reeds as an architectural element were used not just for agricultural buildings, but for basic living constructions as well. Hungarian reeds were even sold in foreign markets, for instance, in the German Democratic Republic, and in the 1960s in the United States. By the end of the 1950s, the channel system that formed a circular shape on the lake was completed and maximised the harvest of reeds (Bognár 1966). Even though scientists have now determined that this has a major impact on the water level and is harmful to the environment (Dinka \& Ágoston-Szabó 2005), these steps led to technical improvement, significant export power, and higher employment. 
Another significant and continuing economic factor in the region was logging and the related silviculture practices as well as their industrial fields (such as work in sawmills at an industrial level, production of forestry machinery, etc.) (Csapody \& Neuwirth 1964). It is very important to emphasise that these activities were not only practised in the region, but education in these fields took place at the highest level. Moreover, the related research was conducted and published in the area as well (Zsámboki 1985: 195-210). These educational activities fostered the procedure of incorporating silviculture into the regional memorialisation processes. Today these educational institutions reflect on their past and document the present, as members of these institutions are heritage owners as well as entrepreneurs (Mastalírné 2014).

After the political change, the over-usage of nature for industrial development has stopped and nature has become "governed" by scientists instead. Academic interest in the region (its flora and fauna, as well as its architectural jewels) has been continuous, but representatives were not able to establish an institutional centre here during the Cold War period. They could only carry out shorter on-site research projects while the Iron Curtain existed. On the other hand, Austrian and Hungarian representatives did communicate with each other and commonly organised public and professional events (such as a cooperative summer camp for professionals and practitioners of environmental protection in 1985 and the first Environmental Protection Conference in Burgenland (the Austrian federal state in the border area) in 1986). They continuously supported the idea of professional cooperation and of a transnational nature park in the 1980s (Kárpáti 1990). It is very important to mention that after the fall of the Iron Curtain a great deal of international acknowledgement and support also led to improvements in the area. For example, the researched territory was chosen to be one of the RAMSAR (Wetlands of International Importance) sites in 1989 (see RAMSAR) and the Council of European Committee launched the PHARE programme (Poland and Hungary Assistance for Reconstruction of Economy) in December of the same year. Through the latter, Hungary received 1.4 million euros worth of assistance to establish the infrastructure of a national park (see PHARE).

The Hungarian national park, established in 1991, includes the south end of Lake Fertó, with its immediate surroundings, including ten settlements, the Hanság Valley to the east of the lake, two smaller lakes, and a floodplain area of the still existing wetlands in the territory of the former (much larger) Lake Fertő (see Conservation). Its Austrian counterpart, Nationalpark Neusiedler See-Seewinkel, was established in 1993, and is comprised of the major part of Lake Fertó/Neusiedlersee, the shallow saline lakes (Seewinkel), and smaller grassland areas (Nationalpark). The different legal statuses and economic 
possibilities caused some difficulties in harmonising the processes in the two countries. Both state and international support (from the World Wide Fund for Nature, for instance) had already been established on the Austrian side, while their Hungarian colleagues needed to resolve legal and territorial questions after the political change. However, the cooperation continued and, as a result, the common national park was formed in 1994 (Kárpáti 2002: 170).

After the unification, the harmonisation of aims, plans, and management directions had to be clarified. The Austrian territory of the lake had already been established as a tourist destination ("the sea of the Vienna population", as the tourist posters phrased it (Békési 2007)), while the Hungarian side could only serve the needs of biologists and environmental specialists, as neither the lake nor its immediate surroundings were in suitable condition for the same kind of leisure activities (Rakonczay 2009: 103-159). The united national park successfully applied for UNESCO World Heritage site nomination as a cultural landscape in 2001, in order to protect the current state of the territory and to maintain the balance of nature and human activities. As a result, the management of the UNESCO cultural landscape does not focus on any particular part of the past; it integrates previous practices in order to protect the still existing valuables (World Heritage 2003), an ideology that follows Jampol's (2014) view of keeping the memorials of the past as tools for facing previous time periods. For instance, reed processing has been transformed into a sustainable format and reeds serve as a natural building material for environment-conscious architectural projects.

The situation could be improved, especially in terms of better cooperation. Currently, on the Hungarian side, different entities are in charge of natural heritage, the internationally acknowledged heritage territory, national and local valuables, and the border. Yet other levels and types of institutions oversee the cultural regions and the public administration of the settlements (VÁTI Kht. 2003). The strictly protected areas are small sections spread out over a relatively wide area, which makes its proper protection and promotion very difficult (Horváth 2005: 17-22). Moreover, numerous acknowledged valuables can be found outside the protected areas, such as noble built heritage of the past, natural beauty, and the traditional lifestyle in harmony with the natural environment. Accordingly, the internationally acknowledged transnational heritage site is hardly definable in terms of location and actual value for the general public. ${ }^{16}$ 


\section{The used past: The acknowledged but not explored Cold War past}

The random examples of cultural projects, which deal with the recent past that might serve the aim of redefining the identity of the region, are very diverse in terms of scale and significance. There have been exhibitions and urban memorials dealing with the lost Jewish population of this territory (Forgotten people 2014), but empty and ruined synagogues can also be found (Kôszeg 2010). They do not have a promising future due to the lack of economic resources or possible owners. Similarly, military structures have either been completely transformed into new uses (such as a hospital in Szombathely, without even mentioning its historical significance on a plaque or through any other form of signage) or left empty, and consequently they are open to total destruction (as in the "dying" Soviet military base in Fertód). ${ }^{17}$ Many scholars (e.g. Lisiak 2010) and contemporary Hungarian representatives ${ }^{18}$ support the idea of eliminating the tangible heritage of the Soviet past as a necessity for a new start. However, the economic and social status of the region demonstrate that such a "material overthrow" alone would not lead to change (Bik 2014).

The only memorialised part of the socialist period is its ending: the successful and bottom-up initiative of 1989, which is discussed below. There are only two private museums engaged in the existence of the Iron Curtain, one dealing with the actual "death zone", and the other focusing on the electronic signal system. These private museums are basically collections of available remnants run by former border guards in Felsốcsatár and Felsốrákos (see the Iron Curtain Museum). Similar to other private initiatives of this kind in Hungary, they are not officially acknowledged as museums. These two exhibitions express pure personal memories that the owners themselves, due to their professions, collected during and immediately after the removal of control systems. The collections consist of what the owners consider worth showing, without consulting any academic or professional organisations or individuals. As Daniel Schacter, Scott Guerin, and Peggy St. Jacques (2011) explain, neither personal nor collective memory is a one-to-one copy of a particular past. Hence, these personal memories do not have more legitimacy based on first-hand experience than other memory products. Although these heritagisation projects have made the narration about the represented past richer with their unique perspectives, they are mainly neglected by the general public. They rarely attract tourists due to a lack of advertising and little knowledge of foreign languages on the part of those who run them (my own research).

The one national and, since 2015, international memorial site of the Cold War period in the researched territory is the Pan-European Picnic Memorial Park. On August 19, 1989, young politically active locals and young people 
from other cities (such as Debrecen), who shared common aims and ideas, organised a peaceful event (with an open fire, dance, and performances by folk ensembles) near the border. The aim was to express the desire for the unity of "European people" and values through a public event and a press conference. A significant number of Eastern German participants (around 600) came to the event due to the rumour that the border was going to be open. They hoped to cross the border and request Western German residence permits in Austria. Even though the border guard soldiers still had the order not to allow border crossing, they decided not to interrupt the free flow of people and the opening of the border. This was the first step (and a peaceful one) in the fall of the Iron Curtain (Kurucz 2000).

A private foundation was formed in 1989 by the organisers of the original event and by young politically active Hungarians to keep and share the memory of this particular action. Today they still provide tours and organise yearly commemorations, having also established and maintained a memorial park at the location where the Pan-European Picnic took place. Today there are numerous art pieces and information boards (Kurucz 2000: 57-58) in three languages (English, German, and Hungarian). This kind of heritagisation, in which more monuments than authentic objects can be seen and, accordingly, both the material subjects of the event and the configuration of the location have been modified, threatens the aim of protecting the memory of the historical events and might even modify them (Bendix 2009: 418).

The "commemorative narrative" of the collective memory (Schwartz et al. 1986: 150) about the Cold War period is fostered at the yearly events of the picnic (organised since 1990), when Hungarians are unified and exemplified. The Pan-European Picnic is emphasised over all other aspects of the given period as it serves the ideological aim of defining Hungarians as the initiators of the end of the Cold War. At those celebrations, Hungarian and foreign political and institutional delegates acknowledge the historical importance of the event in 1989 by joining the participants of the original occasion as well as their relatives (Pan-European Picnic). It is important to add that the location of the celebration (the Pan-European Picnic Memorial Park) is barely accessible with public transport and there are no facilities to serve the needs of the visiting general public. These factors also show the role of political leadership (Whelan 2005: 62) in this ideologically driven heritagisation process (Fig. 7).

There is also an open-air memory site of the former Iron Curtain, established in 2008 by politicians, the local government of Hegykô of 2006-2010. This memorial is located outside the settlement, in between agricultural fields, and contains information boards in two languages (Hungarian and English), and a very short segment of the fan system. Visitors might have the impression that 


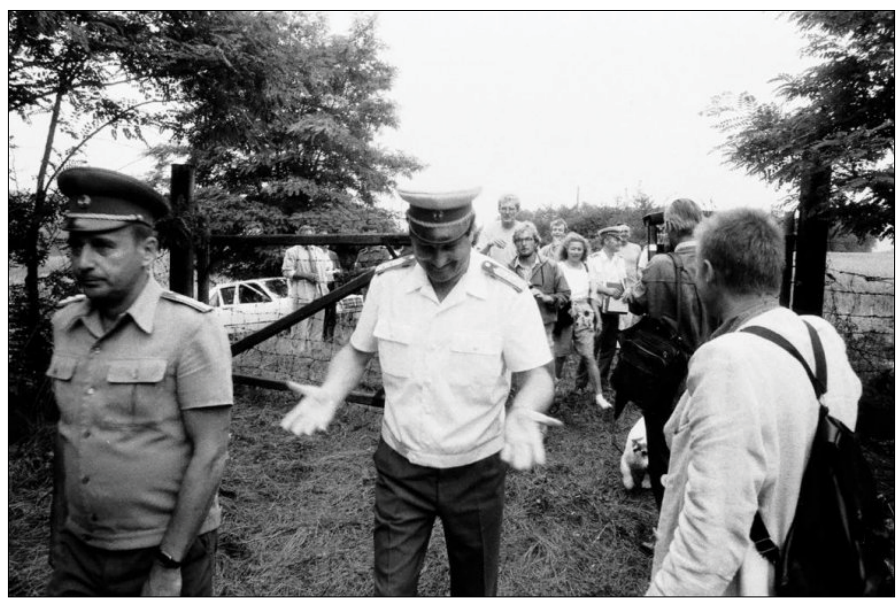

Figure 7. Pan-European Picnic 1989. Pan European Picnic Memorial Park website (http: / / www.paneuropaipiknik.hu /index.php?site=50).

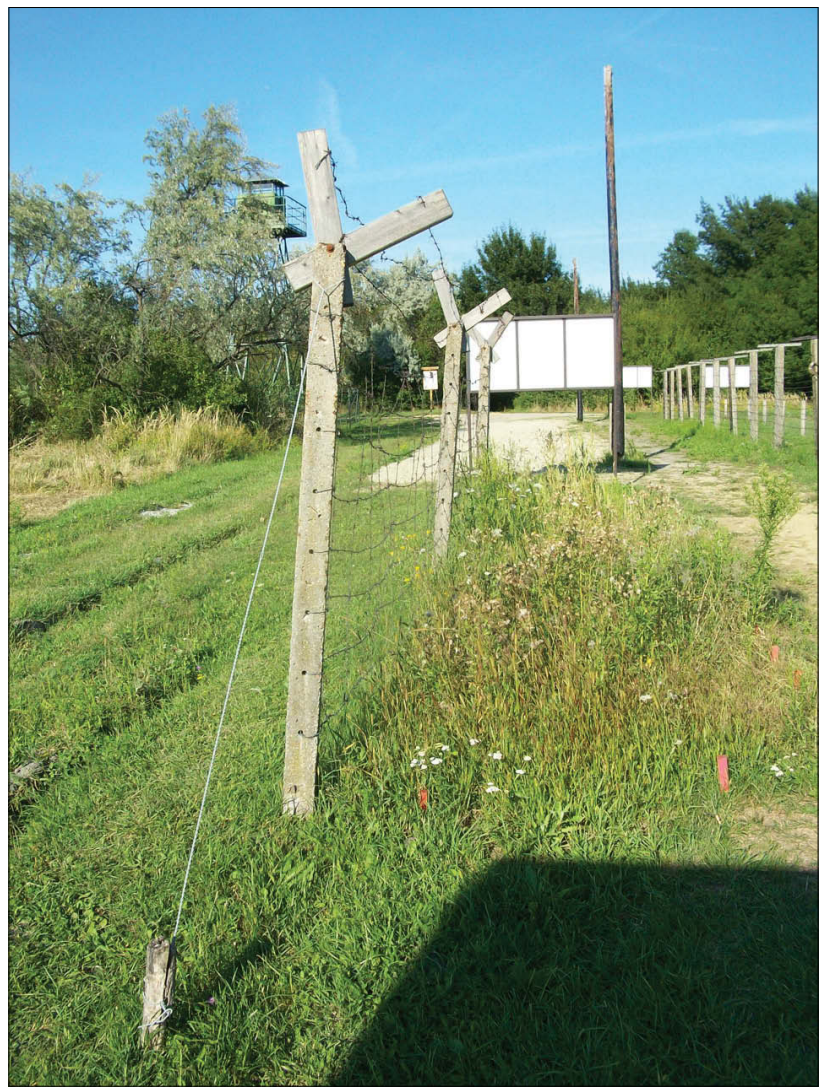

Figure 8. Hegykö Iron Curtain Memorial Site. Photograph by Melinda Harlov-Csortán 2014. 
no one has taken care of this site since its inauguration (as Keszei (2015: 10-18) points out regarding the transformation of memory due to circumstances). There is not even a sign about it within the settlement of Hegykó (Iron Curtain Memorial Site in Hegykó 2012). One can justify the lack of signs, with the authenticity of this memorial (lieux de mémoire; Nora 1986) and (at the time of its inauguration) by the assumed still strong personal and community memory of the location of the former Iron Curtain. The connected emotions and the fact that an undesirable segment of the past is memorialised here also explain its lack of significance (Fig. 8).

\section{What has not been said...}

Despite all the above described advances, the researched territory has been a border zone for almost a half century, characterised by military influence and certain restrictions on locals' opportunities. It is obvious that such circumstances, life standards, and restrictions cannot be forgotten or forgiven easily (Verdery 1999: 85). In the researched territory, through neglecting the memorialisation of these aspects of the past, forgetting is facilitated, especially for the younger generation, who has no personal memories.

The border zone experience also led to the loss of economic significance (from previously being a central zone of the monarchy to becoming a border area) and a significant decrease in standards of living. The drastic change influenced the commercial, economic, and cultural life, as well as the transportation system (Zeidler 2002). Even though an official population exchange did not happen at that time, a significant number of locals moved due to the new circumstances and the establishment of the border (Harcsa 1997: 228). Deportation decreased the population at the end of World War II. Locals with actual or assumed German origin had to leave their homes, where they had lived for generations, and this was often accompanied by harassment and nation-wide media coverage. This forced migration separated friends and families in the region. Settlements lost not just their populations, but also their status in the region, as well as connection with other cities, depending on the level of their military monitor status during the Cold War. They were either stuck between the Iron Curtain and the actual border, or had military bases in or close to them (Sallai 2009: 40). According to Attila Fersch, head of department at the Fertó-Hanság National Park, locals even today feel isolated, as there is very limited cooperation between communities along the border, even though there is no physical barrier any more. ${ }^{19}$ Many settlements have a very small population and almost no employment opportunity or economic capacity, which perpetuates their dead-end character from the past (KSH). Often Austrians buy empty houses and use them 
as summer residences, which does nothing to help energise the settlements' economic or social life. ${ }^{20}$

Former inhabitants, the German-speaking minority, did not return in significant numbers and their memories were commemorated only a decade after the political change with public art memorials (mainly in the form of statues and plaques), financed by either local political leaders or foreign representatives. Similarly, very little scientific research or academic discussion has taken place regarding the economic emigration and later forced deportation, the depressed economy or the still existing consequences of the border status and military presence (Szakolczai 2006: 141-210). Another political moment that could not be memorialised for decades due to the Soviet-supported political leadership and the hegemonic ideology of the country was the 1956 revolution and its aftermath. Only after the political change in 1989, in almost every Hungarian settlement (including the researched area), the 1956 revolution monuments were inaugurated in public spaces. However, these monuments followed general trends and not the local narratives or the specificity of the researched area. For instance, the extensive exodus has been reflected neither in publications nor in public art. ${ }^{21}$

It seems that even psychological traces of the military control can be seen. Besides the already mentioned military presence and constant monitoring (see the Open Society Archives 2016), the inhabitants also suffered from the image created of their area during the Cold War period. It was depicted in propaganda as not just an alienated, closed area, but also as the hot spot of the inner and foreign enemy. Accordingly, not only was the territory considered unattractive, but the people there were seen as suspicious (Jankó \& Tóth 2011). Even today small mirrors at the front windows invisibly reflecting the street view and curious eyes peeking out from behind curtains can be seen in the small towns and villages of the area, unlike in other Hungarian settlements. Locals prefer to hide themselves and their properties, paying minimal or no attention to neighbours or to public events. Representatives of the city of Kószeg (such as the mayor) say that the locals rarely participate in public discussions or elections. ${ }^{22}$ Even today, people in this region almost exclusively leave the products they are trying to sell in front of their houses unattended. Only a box is placed next to the product to collect money (see Turi 1995, and my own research). This practice unique to this region could be attributed to the inhabitants believing that no one would take the products without paying, as everyone is monitored by everyone in public spaces.

Besides on-site research, contemporary publications also show that the current status and identity of the region are still undefined almost three decades after the political change. If we look through marketing and introductory leaf- 
lets, brochures and books from and about the region, produced by the local municipalities, tourist offices, for-profit organisations, etc., no routes to sites are shown to help visitors explore the whole region. The only positive feature of the region that appears in these products multiple times is that it is a quiet untouched area providing a feeling of being close to nature. This feature can be understood as reminiscence and consequence of the past, the closed-in quality of the Cold War era, and the lack of any major new activity or modification since the fall of the Iron Curtain. One of the publications emphasises exactly this consequence of the Cold War period by saying: "Well-preserved thanks to its function as a border between Western Europe and the former Eastern bloc for 40 years" (Nagy 2007: 177); hence, nothing has really changed since 1989.

This natural heritage value on the Hungarian side of the lake also limits the opportunities for ecotourism, which could benefit from bicycle paths and introductory programmes. Ecotourism implies the need of local investment and intensive institutional and organisational management to fulfil the special requirements to protect the heritage. These (financial and operational tasks) have been a heavy burden on the local municipalities and the nature park (see Ecotourism). Such specified tourism also reduces the size of the target audience, the time period for touristic activities, and the number of nights that tourists can spend at one accommodation. Ecotourism in Hungary targets a specific, relatively small group, who prefers active holidays mainly in the spring and summer, when the local flora and fauna are their richest, which is exactly when environmental protection is most necessary. This type of tourism can also be characterised as involving short visits at certain locations or a chain of those through a planned route, which again is problematic since the local transportation and cooperation still have not been developed properly. Accordingly, it seems not even tourism can foster significant change on local levels by local involvement. There have only been a few attempts to adapt this relatively new type of tourism to the aim of preserving and managing local memory, for instance, by establishing and advertising the Iron Curtain bike route. This route, also part of the European Green Belt and the EuroVelo13 programmes, ${ }^{23}$ leads through less touristy but historically more relevant parts of the region (Cramer 2010).

\section{CONCLUSION}

In the part of Hungary explored in this article, the memorialisation of the Cold War period is an ongoing and mainly top-down initiative. The still existing living memories are influenced by diverse local, regional, national, and even inter- 
national processes. Diverse activities have been undertaken by various actors (such as academics coming from outside the researched area, state initiatives, and local for-profit initiatives) and circumstances (depending on whether they have the necessary financial and social support). Among others these aspects, as Lefebvre (1991) emphasises, unquestionably influence the representation of the given area in the receivers' eyes. These receivers are varied: inhabitants are the target audience for the local governmental representatives, international academia are the receivers of academic research, while tourists (both national and international) are the target audience of for-profit organisations. This complex mixture of actors, aims, and approaches makes the case study unique.

The area has been acknowledged by numerous international organisations that have been crucial in the process, especially right after the political change; for instance, international support helped to harmonize the status of the two (Austrian and Hungarian) sides of Lake Fertô and led to further cooperation. On the national level, there has been significant support recently, but it involves quite focused, top-down initiatives that do not see and manage the complexity of sustainable memorialisation. While there have been some bottom-up initiatives and instances of heritagising the everyday life of the pre-Cold War period, there are very few instances that focus on the local specific conditions in the Cold War period. By not heritagising the experience of the Cold War period and the location of the Iron Curtain, the memory of the Soviet past and the people's former identity as Eastern Europeans can be undermined, especially among younger generations (see Jampol 2014). If only pre-Cold War memories are protected and managed in the researched area, a significant time period will be forgotten or overshadowed in the eyes of future generations. Moreover, by not dealing with the recent past, change cannot be realised and the locals will continue to feel that they are living in the shadow of the Iron Curtain.

The local initiatives to preserve either memories of the Cold War or the pre-twentieth century lifestyle through open-air museums or protection of vernacular architecture are promising efforts. Even though more and more civil units are involved in various aspects of tourismification, they are facing mainly economic and operational obstacles and challenges. Local municipalities and regional institutions, such as county museums, expressed interest in, and had the possibility of, playing a role in protecting and managing certain heritage elements of the region after the political change. However, in the last ten to fifteen years they have seemingly lost these opportunities either due to numerous institutional and personal changes or because of the increasing social and economic tasks they have to focus on. There are many abandoned sites of the recent past (such as the former hotel and regeneration centre in Kószeg), which were established by local political powers, but were never brought to completion. These places are on their way to total elimination. 
Even the scholarly community experiences multiple challenges in properly fulfilling its role in the protection and heritagisation processes. Representatives of the natural sciences have been active for many decades and are capable of establishing well-functioning international relations and positions, as well as institutional centres in the researched area. Mainly due to their locations, the same organisations were assigned numerous heritage management tasks, such as raising awareness and motivating participatory actions, for which they have no capacity (lacking human and financial resources). ${ }^{24}$ Monument protection specialists and human rights experts have found it difficult to get access to the territory or to gain economic support for their projects. For example, Tamás Fejérdy, the President of ICOMOS (International Council on Monuments and Sites) Hungary, explained that locals avoid the more costly preservation of monuments, and Csaba Szilágyi, an archivist at the Open Society Archives, mentioned that oral history projects rarely receive the necessary financial support to succeed..$^{25}$

This situation of preferring the memorialisation of the pre-Cold War period over the local experience of the recent past might be based on two contradictory approaches: collective or top-down memorialisation versus personal memories. Personal memories are based on empirical knowledge, whereas top-down memories use learnt knowledge and projected images via mass education, memorials, and connected commemorations (Gyáni 2000). Individuals remember day-to-day struggles and concentrate less on the bigger picture or on the few but celebrated moments that were also dangerous. On the other hand, collective memory and state memory emphasise glorious events with reconstructions and nation-wide propaganda, more suitable to contemporary aims, as they form a more positive self-image. State rhetoric uses the prosperity and capacity of north-western Hungary as examples of sustainable improvement; hence, it has become the representation of the envisaged future for the whole nation, including the ill-suited eastern part of the country. One reason for the still unsuccessful bottom-up local heritagisation projects may be the relatively short period of the establishment of civil society and the practice of participatory action in Hungary. Accordingly, the state memories with the strongest impact have fuelled the collective identity through magnificent and heroic characters and an overall image. On the local level, the 'activated' memories of the region definitely provide economic benefits and new employment opportunities, but the evaluation of their effect on self-image cannot be measured yet. The consequences of such a bipolarised memorialisation process are still unclear. 


\section{ACKNOWLEDGEMENTS}

The research for this article was partially sponsored within the framework of the Visegrád Scholarship at Open Society Archives, and of the "TÁMOP 4.2.1.D15/1/KONV-2015-0006: The development of the innovation research base and knowledge centre in Kószeg within the educational and research network of the University of Pannonia" key project. The latter was subsidised by the European Union and Hungary and co-financed by the European Social Fund.

\section{NOTES}

1 Through personal memories or information acquired about a certain location, the given place has its acknowledged history. For instance, the socialist marching square in the Hungarian capital has no physical sign referring to that function any more, but memory still prevents locals and decision makers from agreeing on and establishing a new function.

2 The lightness, or less stressful nature, of Hungarian memories about the second part of socialism is represented especially in films such as Péter Tímár's works: Egészséges erotika 1986 ('Healthy erotica'), 6:3 avagy játszd újra Tutti 1998 ('6:3 or play it again, Tutti') and Csinibaba 1997 ('Dollybirds'), and Róbert Koltai's Csocsó avagy éljen május 1-e! 2001 ('Table soccer or happy May 1!'). Also, the history and evaluation of socialist public art examples show the same attitude (see Prohászka 1994 and Boros 2001).

${ }^{3}$ For examples of the difficulty of 'heritagising' the Soviet past, see Rasa Baločkaitè (2015) and Oleksandra Gaidai (2015: 137-154).

4 See, for instance, the publications of Miklós Kun (2012), contrasting with Tamás Krausz (2011). The same contrast can also be detected in popular culture between the existing nostalgia for certain aspects of the period, such as car brands, children tales and locations (see the Lost in Hungary documentary series) for a comparison with the outstanding popularity of the aims and motives of the 1956 revolution realised in featured films, songs, and events.

5 Based on available sources, Soviet soldiers were located in Hungary continuously from 1944 to 1991 in different numbers. By the end of the Cold War period, almost 50,000 Soviet soldiers and the same number of Soviet civil servants and their families were living in Hungary. They had approximately 27,000 vehicles at sixty military bases or cities, and at the six airports they controlled. The reason for this large number and their minimal interaction with the locals was that Hungary served as a back-up base to store necessary resources (both human and equipment) to counter a possible aggressive move from the West (Pataki 2000).

6 See the Treaty of Peace with Hungary.

7 About visitors' reports on the difficulties of finding and exploring the site see Ódor 2011 or Sacred Sites 2013. 
8 The Esterházy family was originally a Hungarian noble dynasty, whose ancestors can be traced back to the Middle Ages. They were an influential family loyal to the Habsburgs, and owned substantial estates in the country that was separated due to the Treaty of Trianon after World War I.

9 Numerous members of the Count Széchenyi family, originally from Nógrád County, have dedicated their lives to the improvement of the country and the life of its people. For example, István Széchenyi, along with others, established the Hungarian Academy of Sciences, the national library, and the Chain Bridge (a symbol of the Hungarian capital), using his own money. He is still referred to as "the greatest Hungarian".

${ }^{10}$ For a detailed analysis of the dissolving national monument protection, later called cultural heritage institution system, see Erdôsi 2000.

${ }^{11}$ Interviews with tour guides and employees of both the Bishop's Palace in Fertôrákos and the "little Versailles", in July and August 2016.

12 Monument protection experts did not report on such information (for instance, the diverse minorities' unique building techniques) on the highest (governmental) level. Local party members were only introduced through the protection of "monuments of the working class". Interview with Anna Dobosyné Antall, a leading monument protection specialist, Budapest, July 2016.

${ }^{13}$ One of the most popular blogger's notes on the researched area is available at http:// regi.travellina.hu/?page=hazai\&id=46. See also Turista (http://www.turistamagazin. $\mathrm{hu} /)$.

14 The idea that western Hungary did not need state support for the political and economic change was based on statistical data (Belyó 2010); about the negative consequences of not providing state support, see Freid \& Holka 2011. Local experience supports the latter view, based on the interview conducted in February 2017 with Tamás Taschner, the former head of the regional Tourist Management Office, and currently the Secretary of the Hungarian Committee of the Fertó/Neusiedler; see the World Heritage site.

${ }^{15}$ Lászlómajor, which is operated by the Fertó-Hanság National Park as an on-site educational and communicational unit for the public, and as an integrated research and scientific centre for the institute, is a good example (see Lászlómajor).

${ }^{16}$ See the numerous surveys and research conducted at the Kószeg Campus of the University of Pannonia regarding the sustainable development of the region and its location (see IASK).

${ }^{17}$ Fertôd is very touristy, but only due to the renovated Esterházy Castle. The military base is a part of the settlement that is turning into a ghost town.

${ }^{18}$ Numerous prestigious presenters at the national conference in Eger, Hungary, in September 2016, entitled "1956 and Socialism: Crisis and Rethinking".

19 The discussion took place at the Tourism and Cultural Landscape conference in Budapest in June 2016.

${ }^{20}$ Interview with a local guide at the open-air museum in Sarród in July 2015. 
21 The most popular films and books about these escapes have been written by nonHungarians and produced or published by foreign organisations. The bridge at Andau, Austria, which was the only available route to Austria, has been memorialised and maintained mainly through international and Austrian initiatives. Hungarian academic research dealing with this topic is scarce but relevant, focusing mainly on current (twenty-first century) perceptions of past events. A recent example is Transnational Memories - Hungarian Refugees in 1956 by the Open Society Archives (http://www.osaarchivum.org/podcast/episode1_transitional-memories_hungarianrefugees-in-1956), or the works of the 1956 Institute - Oral History Archive (http:// www.rev.hu/en).

${ }^{22}$ Interview conducted in Kôszeg in August 2016.

${ }^{23}$ More information about these initiatives is available at http://www.europeangreenbelt. org/ and http://www.eurovelo13.com/.

${ }^{24}$ Interview with István Goda, the head of the Ecotourism and Public Relations Department of the Fertó-Hanság National Park, during the three-week on-site research period in January 2017.

${ }^{25}$ Interviews conducted in Budapest in March 2016.

\section{REFERENCES}

Baločkaitè, Rasa 2015. The New Culture Wars in Lithuania: Trouble with Soviet Heritage. Cultures of History Forum. Available at http://www.cultures-of-history. uni-jena.de/debates/lithuania/the-new-culture-wars-in-lithuania-trouble-withsoviet-heritage/, last accessed on November 6, 2017.

Baráth, Magdolna 2013. Adalékok a határvédelem/határốrség második világháború utáni újjászervezéséhez. [Additions to the Reorganisation of the Hungarian Border Guard after World War II.] Betekintó, Vol. 4. Available at http://www.betekinto. hu/2013_4_barath, last accessed on November 6, 2017.

Békési, Sándor 2007. Verklärt und verachtet. Wahrnehmungsgeschichte einer Landschaft: Der Neusiedler See. Vienna: Peter Lang.

Belyó, Pál 2010. Magyarország 1989-2009: A változások tükrében. [Hungary 1989-2009: In the Light of Changes.] Budapest: Központi Statisztikai Hivatal. Available at https://www.ksh.hu/docs/hun/xftp/idoszaki/mo/mo1989_2009.pdf, last accessed on November 6, 2017.

Bendix, Regina 2009. Heritage between Economy and Politics: An Assessment from the Perspective of Cultural Anthropology. In: Laurajane Smith \& Natsuko Akagawa (eds.) Intangible Heritage. London: Routledge, pp. 253-269.

Bik, Oleksii 2014. Andrei Zubov: Rossiia v rezul'tate etoi avantiury okazalas' v polnom tupike. [Russia as a Result of this Adventure Was in a Complete Deadlock.] Glavkom.ua, June 11. Available at http://glavcom.ua/articles/20092.html, last accessed on November 7, 2017. 
Bognár, Dezsô 1966. A fertói nádgazdálkodás. [Reedbed Management at Lake Fertő.] Soproni Szemle, Vol. 20, No. 2, pp. 97-109. Available at http://epa.oszk. hu/01900/01977/00072/pdf/EPA01977_Soproni_Szemle_1966-xx-2.pdf, last accessed on November 6, 2017.

Boros, Géza 2001. Emlék / Mü. [Memory/al.] Budapest: Enciklopédia.

Brown, Adam D. \& Kouri, Nicole \& Hirst, William 2012. Memory's Malleability: Its Role in Shaping Collective Memory and Social Identity. Frontiers in Psychology, Vol. 3, pp. 1-3. http://dx.doi.org/10.3389/fpsyg.2012.00257.

Connerton, Paul 2011. The Spirit of Mourning: History, Memory and the Body. Cambridge: Cambridge University Press.

Cramer, Michael 2010. Iron Curtain Trail Part 3: Along the "Green Belt" from the GermanCzech Border to the Black Sea. Berlin: Esterbauer GmbH.

Csapody, István \& Neuwirth, János 1964. Soproni-dombvidék erdőgazdasági táj. [Forestry Landscape at the Sopron Mountains.] In: István Danszky (ed.) Nyugat-Dunántúl erdôgazdasági tájcsoport Magyarország erdôgazdasági tájainak erdófelújítási erdôtelepítési irányelvei és eljárásai. Budapest: Országos Erdészeti Fóigazgatóság, pp. 519-557.

Danubeparks Association 2000. Danubeparks - Nature Award 2000. Schloss Orth: Danubeparks Association.

Dinka, Mária \& Ágoston-Szabó, Edit 2005. Nagyüzemi aratás hatásai a fertôi nádasállomány reprodukciós folyamataira. [Effects of Large-Scale Harvesting on Reproductive Processes of the Reed Vegetation at Lake Fertó.] In: Katalin Török \& Láng E. Kovácsné (eds.) Válogatás az MTA Ökológiai és Botanikai Kutatóintézet kutatási eredményeiból. Vácrátót: MTA ÖBKI, pp. 37-43.

East, William G. 1932. The Danube Route - Way in History. Economica, Vol. 37, pp. 321345. DOI: $10.2307 / 2548593$.

Eörsi, László 2009. A Corvin közi emléktáblák. [The Commemorative Plaques at Corvin Mews.] História, Vol. 9, pp. 60-62. Available at http://www.historia.hu/userfiles/ files/2009-0910/Eorsi.pdf, last accessed on November 7, 2017.

Erdôsi, Péter 2000. A kulturális örökség meghatározásának kísérletei Magyarországon. [Attempts to Define Cultural Heritage in Hungary.] Regio, Vol. 11, No. 4, pp. 26 44. Available at http://www.academia.edu/6324945/A_kultur\%C3\%A1lis_\%C3\% B6r\%C3\%B6ks\%C3\%A9g_meghat\%C3\%A1roz\%C3\%A1s\%C3\%A1nak_k\%C3\%A Ds\%C3\%A9rletei_Magyarorsz\%C3\%A1gon, last accessed on November 7, 2017.

Fejérdy, Tamás 1988. A nemzetiségi kultúrák építészetének védelme Magyarországon. [Protecting Minorities' Architecture in Hungary.] In: Román András (ed.) Egri Nyári Egyetem. Népek és Nemzetek Közös Épitészeti Öröksége. Eger: TIT, pp. 12-14. Available at https://library.hungaricana.hu/hu/view/SZAK_KOHI_ Kenyee_1988/?pg=0\&layout=s, last accessed on November 14, 2017.

Freid, Monika \& Holka, Gyula 2011. A társadalmi-gazdasági változások néhány vonása az elmúlt 20 évben (1989-2009). [Some Characteristics of the Socioeconomic Changes in the Past 20 Years (1989-2009).] Statisztikai Szemle, Vol. 89, No. 1, pp. 20-49. Available at http://www.ksh.hu/statszemle_archive/2011/2011_01/2011_01_020. pdf, last accessed on November 7, 2017. 
Gaidai, Oleksandra 2015. Memoralization of Lenin: Legislation and Attitudes (On the Materials of Kyiv, Vinnytsia and Cherkasy Regions). Kyiv-Mohyla Humanities Journal, Vol. 2, pp. 137-154. https://doi.org/10.18523/kmhj51031.2015-2.137-154.

Gates-Coon, Rebecca 1994. The Landed Estates of the Esterházy Princes: Hungary during the Reforms of Maria Theresia and Joseph II. Baltimore: The Johns Hopkins University Press.

Gyáni, Gábor 2000. Emlékezés emlékezet és a történelem elbeszélése. [Remembering, Memory, and the Narration of History.] Budapest: Napvilág Kiadó.

Harcsa, István 1997. A vándorlás (migráció). [The Wandering (Migration).] In: István Tarsoly (ed.) Magyarország a XX. században: Természeti környezet, népesség és társadalom, egyházak és felekezetek, gazdaság. Szekszárd: Babits Kiadó, pp. 225231. Available at http://mek.oszk.hu/02100/02185/html/207.html\#II-225, last accessed on November 14, 2017.

Hárs, József (ed.) 2000. Mithras és Oidipusz király. [Mithras and King Oedipus.] In: Fertốrákos. Budapest: Száz magyar falu könyvesháza.

Hirst, William \& Manier, David 2008. Towards a Psychology of Collective Memory. Memory, Vol. 16, No. 3, pp. 183-200. DOI: 10.1080/09658210701811912.

Horváth, Attiláné (ed.) 2005. Örökségünk a Fertố táj. [Our Heritage is the Fertó Landscape.] Fertôd: Porpáczy Aladár Középiskola Szaktanácsadó Intézmény és Kollégium.

Jampol, Justinian A. 2014. Smashing Lenin Won't Save Ukraine. The New York Times, March 3. Available at http://www.nytimes.com/2014/03/04/opinion/smashinglenin-wont-save-ukraine.html?_r=0, last accessed on November 7, 2017.

Jankó, Ferenc \& Tóth, Imre 2011. Az osztrák-magyar határtérség történelme és politikai földrajza. [History and Political Geography of the Austro-Hungarian Border Region.] In: István Németh \& Róbert Fiziker (eds.) Ausztria a 20. században: Az életképtelen államtól a boldogok szigetéig. Budapest: L'Harmattan, pp. 377-403.

Jobst, Ágnes 2013. Vasfüggöny Magyarországon. [Iron Curtain in Hungary.] Betekintố, Vol. 2, pp. 5-7. Available at http://www.betekinto.hu/2013_2_jobst, last accessed on November 7, 2017.

Kárpáti, László 1990. A Fertối Nemzeti Park tervezete. [Planning of the Fertô National Park.] Sopron: Fertô-Hanság Nemzeti Park.

Kárpáti, László 2002. The Common Treasure of Two Countries: The Fertó-Hanság National Park. In: János Tardy (ed.) Cherishing Hungary's Heritage: National Parks and World Heritage Sites. Budapest: Természet BÚVÁR Alapítvány Kiadó, pp. 169-181.

Keszei, András 2015. Emlékek formájában. [In the Form of Memories.] Budapest: L'Harmattan.

Krausz, Tamás 2011. Vitás kérdések a Szovjetunió és Kelet-Európa XX. századi történetében. [Moot Points in the 20th Century History of the Soviet Union and Eastern Europe.] Budapest: Russica Pannonicana.

Kun, Miklós 2012. Sztálin alkonya. [Stalin's Twilight.] Budapest: Unicus.

Kundera, Milan 2009 [1984]. The Unbearable Lightness of Being. New York: Harper Perennial.

Kurucz, Gyula (ed.) 2000. Az elsó határnyitás: Sopron, 1998. augusztus 19. [The First Opening of the Border: Sopron, August 19, 1998.] Budapest: Kortárs Kiadó. 
Lefebvre, Henri 1991. The Production of Space. Oxford: Blackwell.

Lisiak, Agata Anna 2010. Urban Cultures in (Post)Colonial Central Europe. West Lafayette, IN: Purdue University Press.

Macdonald, Sharon 2008. Difficult Heritage: Negotiating the Nazi Past in Nurenberg and Beyond. Abington \& New York: Routledge.

Mastalírné, Zádor M. 2014. A Nyugat-Magyarországi Egyetem története a kezdetektól napjainkig. [The History of the University of West Hungary from the Beginning to the Present.] Könyvtárvilág, Vol. 2, No. 4. Available at http://mke.info.hu/konyvtarvilag/ category/ii_evfolyam_2014/4_szam_2014/, last accessed on November 7, 2017.

Minorics, Tünde 2012. Az Ormánság átváltozása. [The Transformation of Ormánság.] In: Anna Dobosyné Antal (ed.) Ki van itthon?: XVIII. Népi Építészeti Tanácskozás. Budapest: ICOMOS, pp. 178-185.

Molnár, György 1996. Megszállók homályban. [Invaders in the Shadow.] Beszéló, Vol. 1, No. 8, pp. 36-46. Available at http://beszelo.c3.hu/cikkek/megszallok-homalyban, last accessed on November 7, 2017.

Nagy, Csaba 2007. A Fertó-Hanság Nemzeti Park: Ahol a puszták véget érnek. [The Fertô-Hanság National Park: Where the Lowlands End.] Budapest: Alexandra Könyvkiadó.

Navarro, José M. de 1925. Prehistoric Routes between Northern Europe and Italy Defined by the Amber Trade. The Geographical Journal, Vol. 66, No. 6, pp. 481-503. DOI: 10.2307/1783003.

Nora, Pierre (ed.) 1986. Les lieux de mémoire. Vols. 1-3. Paris: Gallimard.

Ódor, Mónika 2011. Egy gyöngyszem az útszélén: A fertôrákosi Mithras-szentély. [A Pearl at the Edge of the Road: The Mithras Sanctuary in Fertórákos.] Talita, August 10. Available at http://talita.hu/magazin/egy-gyoengyszem-az-ut-szelena-fertrakosi-mithras-szentely/, last accessed on November 7, 2017.

Pataki, István 2000. A Magyarországon állomásozó szovjet csapatok létszáma, állomáshelyei és teljes kivonása. [The Number, Positions, and Total Withdrawal of Soviet Troops Stationed in Hungary.] Múltunk, Vol. 45, No. 2, pp. 222-252.

Pótó, János 1989. Emlékmúvek, politika, közgondolkodás. [Memorials, Politics, Public Opinion.] Budapest: MTA Történelemtudományi Intézete.

Prohászka, László 1994. Szoborsorsok. [Fates of Sculptures.] Budapest: Kornétás.

Rakonczay, Zoltán 2009. A természetvédelem története Magyarországon. [The History of Environment Protection in Hungary.] Budapest: Mezógazdasági Kiadó.

Sacred Sites 2013 = Sacred Sites in Hiking Boots. Travelo, October 9. Available at http:// travelo.hu/kozel/2013/10/09/szakralis_helyek/, last accessed on November 7, 2017.

Sallai, János 2009. 20 éves határnyitás: A vasfüggöny léte és vége / 20 Jahre Grenzöffnung: Bau und Fall des Eisernen Vorhangs. Budapest: Hanns-Seidel-Stiftung.

Sallai, János 2012. Egy idejét múlt korszak lenyomata: A Vasfüggöny története. [The Imprint of a Bygone Era: The Story of the Iron Curtain.] Budapest: HannsSeidel-Stiftung. Available at http://www.bm-tt.hu/assets/letolt/konyvjelzo/ AVasfuggonytortenetehudeeng.pdf, last accessed on November 7, 2017.

Schacter, Daniel L. \& Scott, Guerin A. \& Peggy, St. Jacques L. 2011. Memory Distortion: An Adaptive Perspective. Trends in Cognitive Sciences, Vol. 15, No. 10, pp. 467474. http://dx.doi.org/10.1016/j.tics.2011.08.004. 
Schwartz, Barry \& Zerubavel, Yael \& Barnett, Bernice M. \& Steiner, George 1986. The Recovery of Masada: A Study in Collective Memory. The Sociological Quarterly, Vol. 27, No. 2, pp. 147-164. Available at http://www.jstor.org/stable/4106206, last accessed on November 7, 2017.

Szakolczai, Attila 2006. Gyôr-Sopron megye. [Gyôr-Sopron County.] In: Attila Szakolczai \& László Á. Varga (eds.) A vidék forradalma, 1956. Vol. 2. Budapest: Az 1956-os Intézet, pp. 155-164.

Tarsoly, István (ed.) 1997. Magyarország a XX. Században: Természeti környezet, népesség és társadalom, egyházak és felekezetek, gazdaság. [Hungary in the 20th Century.] Available at http://mek.oszk.hu/02100/02185/html/96.html, last accessed on November 3, 2017.

Todorova, Maria \& Dimou, Augusta \& Troebst, Stefan (eds.) 2014. Remembering Communism. Private and Public Recollections of Lived Experience in Southeast Europe. Budapest: Central European University Press.

Tóth, István 1971. A fertórákosi Mithraeum újkori története. [Modern History of Mithraeum in Fertárkos.] Múemlékvédelem, Vol. 15, No. 4, pp. 235-238.

Tóth, István \& Bank, Barbara 2006. Az 1956-os forradalom Sopronban. [The 1956 Revolution in Sopron.] Soproni Szemle, Vol. 60, No. 3, pp. 249-281.

Turi, Rocco 1995. Európai falvak. [European Villages.] Cosenza: Bios.

VÁTI Kht. 2003. Management Plan of the World Heritage Site. Available at http:// www.welterbe.org/files/downloads/managementplan_en/whfns_1_english.pdf, last accessed on November 3, 2017.

Verdery, Katherine 1999. The Political Lives of Dead Bodies: Reburial and Postsocialist Change. New York: Columbia University Press.

Wild, Róbert (ed.) 2000. Bán János: Fertórákos politikai, gazdasági, egyházi és kulturális története. [János Bán: Political, Economic, Religious and Cultural History of Fertốrákos.] Fertórákos: Fertôrákos Község Önkormányzata - Fertórákosi Német Kisebbségi Önkormányzat.

Whelan, Yvonne 2005. Mapping Meanings in the Cultural Landscape. In: Gregory John Ashworth \& Brian J. Graham (eds.) Senses of Place: Senses of Time. Aldershot \& Burlington: Ashgate, pp. 61-71.

Zeidler, Miklós 2002. Társadalom és gazdaság Trianon után. [Society and Economy after Trianon.] Limes, Vol. 2, pp. 5-24.

Zsámboki, László 1985. Fớiskola Selmecen és Sopronban 1904-1934. [College in Selmec and Sopron between 1904 and 1934.] In: A magyarországi müszaki felsóoktatás megindulásának 250. évfordulójára. Miskolc: Nehézipari Múszaki Egyetem, pp. 195-210.

Zsiga, Tibor 1999. A “vasfüggöny” és kora / Der Eiserne Vorhang und seine Zeit. Budapest: Hanns Seidel Alapítvány. 


\section{INTERNET SOURCES}

1956 Institute - Oral History Archive. Available at http://www.rev.hu/en, last accessed on November 7, 2017.

Bishop's Palace in Fertốrákos. Available at http://www.fertorakosikirandulas.hu/ fertorakos/kastely.html, last accessed on November 3, 2017.

Esterházy kastély. [Esterházy Palace.] Available at http://www.eszterhaza.hu/kastely, last accessed on November 7, 2017.

European Green Belt. Available at http://www.europeangreenbelt.org/, last accessed on November 7, 2017.

EuroVelo13. Available at http://www.eurovelo13.com/, last accessed on November 7, 2017.

Fertőd. Available at http://nori.gov.hu/tortenelmi-emlekhelyek/Fertod/fertod-esterhazykastely/, last accessed on November 7, 2017.

Conservation = Fertó-Hanság National Park: Conservation. Available at http://www. ferto-hansag.hu/en/conservation/protected-areas/national-park.html, last accessed on November 3, 2017.

Ecotourism = Fertô-Hanság National Park: Ecotourism. Available at http://www.fertohansag.hu/en/ecotourism.html, last accessed on November 3, 2017.

Fertőszéplak. Available at http://www.fertotaj.hu/hu/ferto-taji_telepulesek/fertoszeplak, last accessed on November 7, 2017.

Forgotten People $2014=$ Forgotten People of Sopron. Available at http://archiv. magyarmuzeumok.hu/kiallitas/1856_elfeledett_soproniak, last accessed on November 8, 2017.

Fortepan Online Photo Archive. Available at http://fortepan.hu/?view=all\&lang=en, last accessed on November 3, 2017.

IASK = Institute of Advanced Studies, Kôszeg within University of Pannonia. Available at http://www.iask.hu/1/s/3431/kraft-kreativ-varos-es-fenntarthato-videk-kozpont, last accessed on November 7, 2017.

Iron Curtain Memorial Site in Hegykô 2012. Available at https://hegyko.hu/programok/ vasfuggony-emlekhely, last accessed on November 3, 2017.

Iron Curtain Museum. Available at http://www.fertorakosikirandulas.hu/fertorakos/ vasfuggony_muzeum.html; http://www.vasfuggonymuzeum.hu/en/contact/, both last accessed on November 7, 2017.

Kôszeg 2010 = Zsinagógamustra Kốszegen - Béres Anikó: Már kihaltak a Schey-féle lovagok. [Survey of synagogues in Kôszeg - Anikó Béres: Schey Knights Have Already Died Out.] Alon.hu, October 28. Available at http://www.alon.hu/ zsinagogamustra-koszegen-beres-aniko-mar-kihaltak-schey-fele-lovagok, last accessed on November 7, 2017.

$\mathrm{KSH}$ (Hungarian Central Statistical Office). Unemployment rate by age groups and gender between 1992 and 2016. Available at https://www.ksh.hu/docs/hun/ xstadat/xstadat_hosszu/h_qlf012a.html, last accessed on November 7, 2017.

Lászlómajor. Available at http://www.ferto-hansag.hu/hu/okoturizmus/bemutatohelyek/ bemutato-majorsag,-laszlomajor.html, last accessed on November 7, 2017.

Lost in Hungary documentary series. Available at http://www.magyarvagyok.hu/videok/ listak/dokumentumfilmek/19535-Elhagyatva-Magyarorszagon, last accessed on November 7, 2017. 
Nagycenk. Available at http://www.nagycenk.hu/index.php?site=214\#1, last accessed on November 7, 2017.

Nationalpark $=$ Nationalpark Neusiedler See-Seewinkel. Available at http://www. nationalpark-neusiedlersee-seewinkel.at/key-facts.html, last accessed on November 3, 2017.

Nemzeti 2014 = Nemzeti Örökség Intézete 2014. [National Heritage Institute.] Information about Nagycenk and Fertód as national and historical memory places. Available at http://nori.gov.hu/nemzeti-emlekhelyek/Nagycenk/nagycenk-szechenyi-kastely/, http://nori.gov.hu/tortenelmi-emlekhelyek/Fertod/fertod-esterhazy-kastely/ last accessed on November 7, 2017.

Open Society Archives. Transnational Memories - Hungarian Refugees in 1956. Available at http://www.osaarchivum.org/podcast/episode1_transitional-memories_hungarianrefugees-in-1956, last accessed on February 8, 2017.

Pan-European Picnic $=$ Pan-European Picnic Memorial Park. Available at http://www. paneuropaipiknik.hu/index.php?site $=50$, last accessed on November 3, 2017.

PHARE $=$ The PHARE Programme and the Enlargement of the European Union. Available at http://www.europarl.europa.eu/enlargement/briefings/33a2_en.htm, last accessed on November 7, 2017.

RAMSAR. Available at http://www.ramsar.org/wetland/austria, last accessed on November 3, 2017.

Regi.travellina.hu. Available at http://regi.travellina.hu/?page=hazai\&id=46, last accessed on November 7, 2017.

Sarród. Available at http://www.sarrodtajhaz.hu/, last accessed on November 7, 2017.

Treaty of Peace with Hungary. Available at https:/www.loc.gov/law/help/us-treaties/ bevans/m-ust000004-0453.pdf, last accessed on November 6, 2017.

Turista. Available at http://www.turistamagazin.hu/, last accessed on November 7, 2017.

UNESCO World Heritage sites in Hungary. Available at http://www.vilagorokseg.hu/ fertoneusiedlersee-cultural-landscape, last accessed on November 3, 2017.

World Heritage 2003 = World Heritage Fertô/Neusiedlersee Cultural Landscape. Management Plan. Available at https://www.welterbe.org/seiten/18, last accessed on November 3, 2017. 


\title{
DISCUSSION
}

\section{CONTEMPORARY TRANSFORMATIONS OF ETHNOLOGY/ANTHROPOLOGY IN RUSSIA: AN INVITATION TO FURTHER DISCUSSION}

\author{
Dmitriy Funk \\ Professor and Chair, Department of Ethnology, Moscow State University \\ Chief Researcher, Tomsk State University, Russia \\ e-mail:d_funk@iea.ras.ru
}

\section{Irina Nam}

Professor, Department of Russian History

Head of the Laboratory for Social and Anthropological Research

Tomsk State University, Russia

e-mail: namirina@bk.ru

\section{INTRODUCTORY REMARKS}

Exactly two years ago, in the 63rd volume of Folklore: Electronic Journal of Folklore, our colleagues Aimar Ventsel and Natalia Struchkova published their reflection on some of the many problems that exist in the post-Soviet academic anthropology - among them the problem of relationships between academic traditions and academic writing culture (Ventsel \& Struchkova 2016: 121-126). Here we would like to continue this discussion and elaborate on a few other issues which are, in our view, characteristic of anthropology in Russia in the first place but also in other countries of the post-Soviet space. ${ }^{1}$

The breakaway from old paradigms of Soviet/Russian ethnography and its academic language coincided in time with the dissolution of the USSR and was unambiguously marked within the discipline by renaming of the main and, in fact, only ethnographic academic journal available at that time: in 1992, Etnograficheskoe obozrenie (Ethnographic Review) replaced Sovetskaia etnografiia (Soviet Ethnography). Coincidentally or not, the new title alluded to the possibility of the continued presence of ethnography in post-Soviet Russia, with an indispensable return to the evolutionary paradigm that existed a hundred years ago (Etnograficheskoe obozrenie had already been issued in Russia in the period from 1889 to 1916). Luckily, the reality turned out to be 
different, and the title Etnograficheskoe obozrenie proved to be, as it seems, just an indicator of the then confusion among Russian researchers and hence their attempt to regain confidence in the future through returning to the 'roots'. Also indicative in this regard is the fact that in 1992-93 practically each issue of the renewed journal contained in its special section titled "Reflection on the discipline's future" a dozen of utterly thought-provoking articles that criticized or defended the previously applied approaches, and offered thoughts on the history of the discipline and the fate of researchers in it along with predictions about the future of ethnography (Tishkov 1992: 5-20; Basilov 1992: 3-17; Markov 1992: 3-7; Shnirelman 1992: 7-18; Kon 1993: 3-8; Arutiunov 1993: 8-14; Sokolovskiy 1993/2: 3-13; 1993/3: 3-14).

It is rather interesting to explore the way this discussion further unfolded. As regards Etnograficheskoe obozrenie, some articles on this topic reappeared in it only in 1994 and 1996; afterwards, the section "Reflection on the Discipline's Future" (whose very title started to induce sadness) was turned into a more neutral "Issues of theory and methodology" or "Issues of theory", although it occasionally featured publications on research questions and traditions in Russian ethnography (see, for example, Semenov 1998: 3-17; Basilov 1998: 18-45; Karlov 2000: 3-21).

The reflection on 'the discipline's future', which varied thematically and in terms of the language used and happened to sporadically occupy the journal's pages also after the year 2000 , has, since 2005 , completely disappeared from Etnograficheskoe obozrenie. It was in that very year that some old sections were excluded from the journal, and an approach was adopted to publish the journal's special issues edited by guest editors. That turn, in our opinion, has radically changed the journal itself and the way anthropology was and is viewed in Russia. This, however, does not mean that thinking about the history and future of ethnography was neglected. Not at all. On the one hand, the understanding of the discipline changed, widened to what it was and is elsewhere, and, following their European and American counterparts, many Russian researchers started to call it anthropology, only at times narrowing this name down to social or cultural anthropology. On the other hand, the reflection referred to above also remained. It is just that it was extended to cover similar issues raised in the field of anthropology outside Russia (Elfimov 2005: 4-101; Elfimov 2012), and also, this kind of reflection on the fate of Russian ethnography (ethnology/ anthropology) would appear more often in other Russian journals - those on culturology and history (Tishkov 2002: 3-18; Sokolovskiy 2003: 136-159; 2009: 45-64; 2011: 70-89; Tishkov \& Pivneva 2010: 3-21; Funk 2014: 93-102).

Many aspects of the transformation processes in ethnography (which in most cases started to be called 'ethnology' or even 'anthropology' in the post- 
Soviet academia's language) have already been considered in detail. Below, we would like to discuss only three cases which seem worthy of attention in terms of identifying significant transformations or, conversely, revealing a lack of any noticeable progress over the last two and a half decades. These include the issue of developing high-quality BA and MA programmes at universities, the non-availability of textbooks / specialized collections (and of the very access to contemporary research literature in the field), and the lack of high-quality specialized journals. We believe that the speed and quality of further changes in Russian anthropology will largely depend on whether or not these issues will be tackled successfully, if at all.

First of all, the term 'anthropology' itself should be commented upon on our part. The quiet revolution that Etnograficheskoe obozrenie experienced in 2005 finally resulted in the fact that the journal has, 'by default', adopted a new understanding of anthropology as a research area without any debates or battles over the 'necessity' to retain and accentuate ethnicity-related themes (that were, in fact, imposed on researchers by the very term 'ethnography' or 'ethnology').

Below, in our discussion about anthropology, we use the common understanding of the structure of this social discipline comprised of the so-called Boas tetrad: 1) social, cultural or socio-cultural anthropology; 2) linguistic anthropology; 3) biological or physical anthropology; and 4) archaeology. However, it should be noted here that such an understanding is far from being shared by all our colleagues and that even the so-called 'passport of the specialty of ethnography, ethnology, and anthropology' (available on the website of the Higher Attestation Commission of the Russian Federation) presents the discipline as it used to be seen in the USSR thirty or, rather, forty years ago - with references to ethno-genesis, classic descriptive ethnography, ethnic history, and ethnological regional studies as the first (and most important?) of the possible research foci. ${ }^{2}$

\section{DESCRIBING ANTHROPOLGY AT UNIVERSITIES}

Starting with ethnological/anthropological education at Russian universities, it should be said that it is the most significant aspect when it comes to assessing the state of anthropology, as universities are the places where one has the opportunity to develop interest in a given discipline as well as analytical skills, which will then allow some of the students to become researchers (including at universities themselves), employees of government bodies, museum workers, experts working in the media, at various foundations, and consulting agencies.

During the recent Soviet past (the post-war period), dealing with ethnography in the Russian Soviet Federative Socialist Republic (RSFSR) was quite 
easy: there were specialized departments at the Moscow and Leningrad State Universities and later on, beginning in 1985, at Omsk University as well - all three being part of the respective history faculties. Practically all of the first decade following the collapse of the USSR was the time when former staff from faculties of philosophy and sociology was searching for their place under the new and extremely difficult socio-economic conditions. In the 1990s and, probably, in the first half of the 2000s as well, complete confusion reigned in Russia in relation to the content of old and new educational programmes whose titles contained the terms 'ethnology', 'social anthropology', 'cultural anthropology', and 'philosophical anthropology'. These programmes would often (or even, as a rule) be run by Russian colleagues with no specialized education in ethnology. However, already in the first decade of the 21st century, at least at two universities the situation gradually started to change for the better. The ethnological faculty of the European University at Saint Petersburg and the Study and Research Centre of Social Anthropology (SRCSA) at the Russian State University for the Humanities (Moscow) pioneered the radical change in educational standards in social and cultural anthropology.

Thanks to the efforts undertaken by Valeriy Tishkov, Director of the SRCSA (and for a long time Director of the Institute of Ethnology and Anthropology of the Russian Academy of Sciences in Moscow), and Olga Artemova, Deputy Director of the SRCSA, federal state educational standards for the subject area "Anthropology and ethnology" were developed and introduced: in March 2010 for master programmes and in November 2011 - for bachelor programmes. There seemed to be only one step left to be made from these educational standards toward their implementation through elaboration of quality BA and MA programmes, creation (or re-training) of specialized departments, centres, and laboratories, and, finally, allocation of state-funded places at universities that could be viewed as a kind of social order for specialists on the part of the state. In the end, this step was made by the Faculty of Anthropology ${ }^{3}$ at the European University in Saint Petersburg - in the form of a master programme introduced here - but also by the Department of Ethnography and Anthropology at the Institute of History at Saint Petersburg State University ${ }^{4}$ by the Department of Archaeology and Ethnology of the Institute for the Humanities and Arts, the Department of History at the Ural Federal University, ${ }^{6}$ by the Far Eastern Federal University (it is called here "Anthropology of Asia-Pacific region"); by the SRCSA at the Russian State University for the Humanities in Moscow ${ }^{8}-$ within both bachelor and master programmes - and by the faculties of history of Kazan (Privolzhie) Federal University (Department of the History of Tatarstan, Archaeology, and Ethnology) ${ }^{9}$, of Omsk State University (Department of Ethnology, Anthropology, Archaeology, and Museology $)^{10}$, and, starting from 
2015, of Tomsk State University (Laboratory for Social and Anthropological Research, http://lsar.tsu.ru/en//) ${ }^{11}$.

It would not be right to state that the abovementioned university centres for educating anthropologists/ethnologists, as well as the subject area of "Anthropology and ethnology" as such, are the only and best ones in Russia today. There is, for example, a quite well-developed and professionally run master programme on social anthropology at the Department of Cultural Anthropology and Ethnic Sociology (Faculty of Sociology) of Saint Petersburg State University. ${ }^{12}$ As for the country's largest university - Lomonosov Moscow State University - for many decades, two faculties have been educating specialists in anthropology here: the Faculty of Biology (Department of Anthropology), ${ }^{13}$ where students specialize in general anthropology, anthropogenesis, human morphology, and ethnic anthropology; and the Faculty of History (Department of Ethnology), ${ }^{14}$ which offers specialization in sociocultural anthropology.

For the sake of justice, it should be noted that educational programmes titled "Anthropology and Ethnology" do exist at a few other Russian universities (e.g., a master programme implemented in 2013 at the Department of Philosophy and History of Science, Faculty of Art History and Intercultural Communication, at Belgorod State Institute of Arts and Culture ${ }_{2}^{15}$ or at the Department of Social Anthropology and Ethnonational Processes, Faculty of Philosophy, at Orlov State University named after I.S. Turgenev, ${ }^{16}$ but it is rather difficult to say how these programmes as well as the staff of these departments (who are candidates and even doctors of pedagogical, philosophical, agricultural, and, more rarely, historical and other sciences) are connected with sociocultural anthropology. At a number of universities, there are departments of different anthropologies (philosophical, psychological, pedagogical, and other) whose relationship with sociocultural and/or biological/physical anthropology is, for the most part, equally unclear.

There are no centres of linguistic anthropology in Russia yet, with the exception of the Laboratory of Linguistic Anthropology, established at Tomsk State University in 2017, and a series of lectures delivered on this subject area in bachelor and/or master programmes at the Department of Ethnology of the European University at Saint Petersburg, as well as Lomonosov Moscow State University.

One of the greatest challenges facing the introduction of quality education and training in anthropology/ethnology is that the discipline is being predominantly affiliated with the history faculties/departments - the fact that does not allow students to start specializing in anthropology/ethnology during the first two years of study. We will not go into the long-held dispute over the benefits (or absence thereof) of teaching history to students of anthropology in Russia, 
but only note that viewing ethnology as a historical discipline keeps ethnology anchored in the arts and humanities, whereas anthropology in the broad sense that we elaborated upon above belongs to the social sciences. Having gained hands-on experience in educating ethnologists at the history faculties of Russian universities, we can confidently argue that trying to enrich a bachelor programme with a variety of lectures and practical classes needed for proper education and training of anthropologists is simply impossible in the current situation for at least one reason - at history faculties, only semesters from the fifth to the seventh are allocated to specialization in ethnology per se, with the eighth semester being a concluding one and thus better left for students to write their (bachelor) qualification theses.

Another, no less important, issue is that of university teacher training and development. However attractive the names and even the content of syllabi may be, a good impression of educational programmes can easily be spoiled by the lack of adequate competency on the part of the teacher. Most of the specialized (in anthropology) faculties do not have faculty members with special international anthropological training, either Russian nationals or specialists invited from abroad. Also, the educational programmes available either do not offer or barely ever offer important lecture courses in Western European languages. In the past four to five years, anthropological courses seem to have regularly been taught (in English) at two Russian universities only: at the Department of Ethnology, Lomonosov Moscow State University (courses: "American Indians: Histories and cultures", "Developing and managing applied anthropology projects", "The anthropology of space", "Tribal peoples in the modern world" by Professor Andrew Wiget, and "Anthropology of migration" and "Anthropology of childhood" by Dr. Elena Khlinovskaya Rockhill), and at the Laboratory for Social and Anthropological Research, Tomsk State University (courses "Ethnology, French style: The 20th century" by Professor Otto Habeck, "Modern approaches in anthropological studies of religion" by Dr. Agnieszka Halemba, "Introduction to the anthropology of music" by Dr. Ioannis Tsioulakis, and some others).

\section{WHAT AND WHERE TO READ?}

While discussing university education and training in anthropology, we cannot but turn to the issue of educational and research literature as well. One could wonder what kind of a problem there is with the literature when it comes to textbooks, for example. However, it is this overreliance on textbooks, where 'everything about everything' is presented to students in a condensed way, that causes difficulty for the development of anthropology as a social science. 
We cannot say to either the society as a whole or to some part of it: "Halt! I am going to describe you now". Textbooks on anthropology can be (and are) compiled, based on two main principles: description of static phenomena, referring, as a rule, to the period of the late nineteenth to the early twentieth centuries (in other words, describing something that ceased to exist long ago, and often doing so in a research language that could be seen as characteristic of colonial ethnography) or introduction to a certain theme drawing on collections of works comprised of best anthropological research writings. With very few exceptions, of the two only the first principle applies to Russia.

Nevertheless, as regards the introduction to anthropology, thanks to the efforts of colleagues from the Institute of Ethnology and Anthropology (Russian Academy of Sciences) and the Higher School of Economics, students have been presented with two remarkable textbooks over the recent time, namely, Social Anthropology: Investigating Human Social Life by Alan Barnard (2009) and What is Anthropology? by Thomas Hylland Eriksen (2014). Where does the problem lie then? We think in the very language in which contemporary anthropology is written.

In relation to the collections of works mentioned, this means that these either need to be read in the original (in a foreign language) or be translated into Russian. The second option is possible but difficult to realize due to the enormous volume of such collections out there, let alone the necessity to obtain permission from publishing houses to translate these texts. Such collections are indeed numerous; Wiley-Blackwell alone has published a few dozens of textbooks/readers in social and cultural anthropology, ${ }^{17}$ and this publishing company is far from being the only one actively issuing collections of the kind. Alas, Russian colleagues have little to offer in this regard - no readers, either of their own making or translated into Russian.

In practice, the problem is even far more complex. All the texts in the collections of works published abroad were created within other research schools; all of them are a result of previous long-held discussions and thus have their own history and predecessors. Often, this history cannot be read on the collection's pages themselves; it is omitted because professors who use these books in class know the entire material and can always introduce their students to one discussion or another where needed. But we do not feel confident about our Russian colleagues working at all of the specialized faculties being able to deliver the same quality introduction to the anthropology of religion, the anthropology of childhood, the anthropology of migration or epistemology of anthropology (we could go on). Why? One of the reasons is that lack of knowledge of foreign languages is rather a norm than an exception at the majority of Russian anthropology faculties; another reason consists in that a significant 
part of research institutions, including the academic Institute of Ethnology and Anthropology, do not have access to electronic journal databases. Here, however strange it may seem, some Russian universities such as the Higher School of Economics, the Russian State University for the Humanities, Lomonosov Moscow State University, the European University at Saint Petersburg, Tomsk State University, and a few others are well ahead of other, purely research institutions. That said, there is still no institution in Russia that would have access to such a wide and rich variety of journals, books, dissertations, and abstracts that, for example, Max Planck Institute for Social Anthropology (Halle/Saale, Germany) has at its disposal. Our colleagues who work at this institute can at any time access thirty-four electronic databases on anthropology literature of the broadest spectrum possible. ${ }^{18}$

We think that it is only issuing additional funding to help provide access to the research literature but also having the time needed for researchers to read this literature on a regular basis that can definitely change the current situation for the better in the foreseeable future.

\section{JOURNALS}

One of the most important, if not crucial, indicators of a researcher's success is without doubt his or her publication activity, which directly depends on the availability of professional journals. If only two and a half decades ago Sovetskaia etnografiia / Etnograficheskoe obozrenie was the only professional journal for Russian ethnographers to publish in, along with such journals as Vostok (East), Slavianovedenie (Slavic Studies) or, say, Chelovek (Man), which also accepted some anthropological/ethnographic articles, today the number of more or less anthropology-related journals has grown at least five times, and it is hardly possible to try and list all of the journals which in principle accept anthropological works for publication (especially taking into account the unimaginable number of all kinds of Vestnik (Bulletins), Trudy (Works), and Uchenye zapiski (Scholarly Notes), released at different universities and pedagogical institutes.

The growth in the number of specialized journals is an obvious achievement of the post-Soviet development of anthropology. However, now we are faced with another serious issue - that of quality of these journals. It is no secret that the introduction of the so-called list of journals (to publish in for those seeking higher academic degrees) by the Higher Attestation Commission of the Russian Ministry of Education entailed the creation of many new journals which accept literally everything for publication, and so researchers who pur- 
sue the academic degrees of Candidate of Sciences or Doctor of Sciences have the opportunity to publish three of four or even fifteen to twenty 'academic' papers within the space of one year, right in the run-up to the defence of their dissertations. It is, though, beyond the limits of the possible to find examples of serious researchers in anthropology being able to publish such a big number of respectable articles (if to leave out overviews and reviews) outside this vicious system over the same period of time. Why is this possible in Russia? The key to this 'success' is the local character (local journals) ${ }^{19}$ of many of the Russian journals. So the journals often find themselves to be 'at the service' of institutional interests and place on their editorial boards professors and other teaching staff of the university or faculty at which they are issued. They allow themselves to publish articles written by almost exclusively by their 'own' staff and, finally, they either do not peer-review these articles of their 'own' authors or review them by themselves as a formality.

A look at the authors' names featured even in the most well-known Russian anthropological/ethnological journals and, more specifically, in Etnograficheskoe obozrenie ${ }^{20}$ allows us to see that all of them are at best 'national', not 'international'. This fact has its impact on the reputation of these journals and interest in the articles published by them.

Speaking further of the international profile of journals, it is worth paying attention to one more important aspect, namely, their presence (or in the case of Russian journals, rather, non-presence) in the largest international journal databases and/or indexing systems. As a result of purely administrative effort undertaken by academia's managers to find a way of assessing the quality of research in the social sciences and humanities, the inclusion of journals in databases such as Web of Science, Scopus, and, probably, also Springer was prioritized, whereas a database such as ERIH (currently called ERIH PLUS European Reference Index for the Humanities and Social Sciences) was at first ignored, and another huge database - EBSCOhost, Scopus's direct partner, continues to be ignored as of today.

The inclusion or non-inclusion (or, often, editorial board's conscious abstention from trying to get their journal included) of a given journal in one of the mentioned databases or indexing systems, as our colleagues would well know, cannot be considered the only criterion for assessing the quality of this journal, and, by extension, of the texts published in it (for more see Funk 2016: 8-26). However, with academia's managers forcing scholars to play by their own rules, we have to take into account this criterion as well. In the case of Russian journals, the picture is not quite optimistic. As of 2016, among professional anthropological journals, only three Russian journals were indexed in Scopus $^{21}$ - Siberian Historical Research (Q3, SJR 0.195), Social Evolution and 
History (Q3, SJR 0.157), and Etnograficheskoe obozrenie (Q4, SJR 0.112), occupying the $163 \mathrm{rd}, 184 \mathrm{th}$, and $243 \mathrm{rd}$ lines out of 315 . It is hardly worth saying that out of seventy-nine journals in the Q1, only fifteen are issued outside of the US and UK. So anthropology remains a science whose lingua franca is English.

We find it difficult to foresee how fast (if at all) the current state of affairs can be altered. One way could be to try and solve the problems by administrative means, and there is an example of this, namely the creation of a separate subgroup of Russian journals (currently 635!) - the RSCI, Russian Science Citation Index - based on the Web of Science platform. Another way, though, could be to simply start forming international editorial boards for Russian journals, and seeking the broadest authorship possible, while using the widely recognized principle of double blind peer-review. Given this is done, the recognition of Russian journals, along with their inclusion in the best international databases and indexing systems, will undoubtedly follow.

\section{CONCLUDING REMARKS}

The picture we have presented above seems to be rather gloomy. At times, though, such a perspective, somewhat more dramatic on purpose, is necessary in order to fully realize the scale of what needs to be done. The issues raised in this article do not exhaust all the weaknesses of Russian anthropology/ ethnology, and certainly they are not unique to this discipline, at least in the post-Soviet space.

We hope that here we managed to offer some food for thought and further discussion among our colleagues: through our intellectual exchange and joint efforts it would be much easier to state problems and find solutions thereto.

\section{ACKNOWLEDGEMENTS}

The article is written within the framework of the project, entitled "Man in a changing world. Identity and social adaptation: Past and present" (Russian government grant \# 14.B25.31.0009). 


\section{NOTES}

1 The article draws on the theses put forward by Dmitriy Funk at the session of the Division of Historical and Philological Sciences of the Russian Academy of Sciences, held in Moscow on December 16, 2014, and at the 11th Congress of Russian Anthropologists and Ethnologists, held in Yekaterinburg on July 2, 2015 (Funk 2015: 38-44). It is also based on the authors' joint presentation at the international conference "Science of the future", held in Kazan on September 21, 2016 (Funk \& Nam 2016: 134-136).

2 The specialty "Ethnography, ethnology, and anthropology" studies the history and contemporary state of mankind in the form of its specific groups - ethnoses - in the territory of the oecumene (the Earth's inhabited space) and at all stages of its evolution. Ethnoses (ethnic communities, i.e., tribes, peoples, nations, ethnic minorities, and suchlike groups) are social associations comprising many components and having a complex internal structure. Ethnoses and their groups can be studied both as a whole and in terms of their components (language, environment, cultures, everyday life, consciousness and self-consciousness); as an ethnos is in essence fragments of the society (per se), research into it is distinctly multi-sided (http://vak.ed.gov.ru/docume nts/10179/2327517/07.00.07+\%D0\%AD\%D1\%82\%D0\%BD\%D0\%BE\%D0\%B3\%D1\%8 $0 \% \mathrm{D} 0 \% \mathrm{~B} 0 \% \mathrm{D} 1 \% 84 \% \mathrm{D} 0 \% \mathrm{~B} 8 \% \mathrm{D} 1 \% 8 \mathrm{~F} \% 2 \mathrm{C} \% 20 \% \mathrm{D} 1 \% 8 \mathrm{D} \% \mathrm{D} 1 \% 82 \% \mathrm{D} 0 \% \mathrm{BD} \% \mathrm{D} 0 \% \mathrm{BE}$ $\% \mathrm{D} 0 \% \mathrm{BB} \% \mathrm{D} 0 \% \mathrm{BE} \% \mathrm{D} 0 \% \mathrm{~B} 3 \% \mathrm{D} 0 \% \mathrm{~B} 8 \% \mathrm{D} 1 \% 8 \mathrm{~F} \% 20 \% \mathrm{D} 0 \% \mathrm{~B} 8 \% 20 \% \mathrm{D} 0 \% \mathrm{~B} 0 \% \mathrm{D} 0 \% \mathrm{BD} \%$ D1\%82\%D1\%80\%D0\%BE\%D0\%BF\%D0\%BE\%D0\%BB\%D0\%BE\%D0\%B3\%D0\%B8\% D1\%8F.doc/10abc054-814a-4460-8071-3ea4a81121f9).

3 From 1995 to 2008 the Faculty of Ethnology. See https://eu.spb.ru/anthropology/about.

4 See http://history.spbu.ru/etnogr-o-kafedre.html. The master programme "Ethnological inspection" was accredited here in 2014 but in general this department has a long history of educating students of ethnology, from the time when - after a fifteen-year break - ethnographic education was resumed at the university in 1967.

5 From 1990 almost up until the end of 2001 the Department of Ethnology and Specific Historical Disciplines.

6 See http://www.hist.igni.urfu.ru/kafedra/client/text.asp?aid=23\&np=1\&ns=1, last accessed on November 21, 2017.

7 See https://vladivostok.postupi.online/vuz/dvfu/programma-magistr/4514/, last accessed on November 21, 2017.

8 See https://www.rsuh.ru/education/section_228/section_289/, last accessed on November 21, 2017.

9 See http://kpfu.ru/imoiv/struktura/otdeleniya/vysshaya-shkola-inostrannyh-yazykovi-perevoda/kafedra-arheologii-i-etnologii, last accessed on November 21, 2017.

${ }^{10}$ See http://ethnography.omskreg.ru/, last accessed on November 21, 2017.

${ }^{11}$ See http://sar.tsu.ru/en/, last accessed on November 21, 2017.

${ }^{12}$ See http://soc.spbu.ru/fakultet/departments/antropol/, last accessed on November 21, 2017. 
${ }^{13}$ See http://anthrop.bio.msu.ru/, last accessed on November 21, 2017.

${ }^{14}$ See http://hist.msu.ru/departments/4011/, last accessed on November 21, 2017.

${ }^{15}$ See http://bgiik.ru/73, last accessed on November 21, 2017.

${ }^{16}$ See http://oreluniver.ru/edustruc/chair/279, last accessed on November 21, 2017.

${ }^{17}$ See http://eu.wiley.com/WileyCDA/Section/id-351621.html?filter=TEXTBOOK, last accessed on November 21, 2017.

18 The information (as of January 2014) was kindly provided by the staff at the Library of Max Planck Institute for Social Anthropology.

${ }^{19}$ In this case, we refer to the criteria for journals used by ERIH PLUS (https://dbh.nsd. uib.no/publiseringskanaler/erihplus/about/approval_procedures):

- Authorship is international when less than two thirds of the authors published in the journal are from the same country;

- Authorship is national when more than two thirds of the authors published in the journal are from the same country;

- Authorship is local when more than two thirds of the authors published in the journal are from the same institution.

${ }^{20}$ See http://journal.iea.ras.ru/, last accessed on November 21, 2017.

${ }^{21}$ See http://scimagojr.com/journalrank.php?category=3314\&area=3300, last accessed on November 21, 2017.

\section{REFERENCES}

Arutiunov, Sergei 1993. Preodolenie kakogo krizisa? [Overcoming What Crisis?] Etnograficheskoe obozrenie, No. 1, pp. 8-14. Available at http://journal.iea.ras. ru/archive/1990s/1993/1.htm, last accessed on November 22, 2017.

Barnard, Alan 2009. Sotsial'naia antropologiia: Issleduia sotsial'nuiu zhizn' liudei. [Social Anthropology: Investigating Human Social Life.]. Moscow: Institut etnologii i antropologii RAN.

Basilov, Vladimir 1992. Etnografiia: est' li u nee budushchee? [Ethnography: Is There Any Future?] Etnograficheskoe obozrenie, No. 4. pp. 3-17.

Basilov, Vladimir 1998. Traditsii otechestvennoi etnografii. [Traditions of National Ethnography.] Etnograficheskoe obozrenie, No. 2, pp. 18-45.

Elfimov, Aleksei (ed.) 2005. Distsiplina i obshchestvo: natsional'nye traditsii. [Discipline and Society: National Traditions.] Etnograficheskoe obozrenie, No. 2, pp. 4-101. Available at http://journal.iea.ras.ru/archive/2000s/2005/2.htm, last accessed on November 22, 2017.

Elfimov, Aleksei (ed.) 2012. Antropologicheskie traditsii: Stili, stereotipy, paradigmy. [Anthropological Traditions: Styles, Stereotypes, Paradigms.] Moscow: Novoe literaturnoe obozrenie. 
Eriksen, Tomas Hilland 2014. Chto takoe antropologiia? [What Is Anthropology?] Moscow: Izdatel'skii dom Vysshei shkoly ekonomiki. Available at http://www. netcabinet.ru/uploads/8/5/0/9/8509295/chto_takoe_antropologia.pdf, last accessed on November 22, 2017.

Funk, Dmitrii 2014. Obsuzhdenie perspektiv razvitiia kafedry etnologii MGU. [Discussing the Development Prospects of the Department of Ethnology of the MSU.] Istoricheskii zhurnal: Nauchnye issledovaniia, No. 1, pp. 93-102. DOI: 10.7256/2222-1972.2014.1.12191.

Funk, Dmitrii 2015. Ob itogakh i problemakh sovremennykh transformatsii etnologii/ antropologii v Rossii. [On the Outcomes and Problems of Modern Transformations in Ethnology/Anthropology in Russia.] In: V. Tishkov \& A. Golovnev (eds.) XI Kongress antropologov i etnologov Rossii: Sb. materialov. Ekaterinburg, 2-5 iiulia $2015 \mathrm{~g}$. Moscow \& Ekaterinburg: IEA RAN \& IIiA UrO RAN, pp. 38-44.

Funk, Dmitrii 2016. Naukometriia v otsenke kachestva publikatsii v sotsial'nykh i gumanitarnykh naukakh. [Scientometrics and Evaluation of Publications in Social Sciences and Humanities.] Sibirskie istoricheskie issledovaniia / Siberian Historical Research, No. 1, pp. 8-26. DOI: 10.17223/2312461X/11/2.

Funk, Dmitri \& Nam, Irina 2016. Identifying Social Anthropology within the Russian University System: The Case of Tomsk. Science of the Future: Proceedings of the Conference - Kazan 2016 (Kazan, September 20-23, 2016). Moscow: Inconsult, pp. 134-136. Available at http://sf-conf.com/assets/files/Proceedings-of-theconference2016.pdf, last accessed on November 22, 2107.

Karlov, Viktor 2000. Etnonatsional'naia refleksiia i predmet etnologii (k probleme samosoznaniia nauki). [Ethnonational Reflection and the Research Focus of Ethnology (toward the Issue of Self-Consciousness of Science).] Etnograficheskoe obozrenie, No. 4, pp. 3-21. Available at http://journal.iea.ras.ru/archive/2000s/2000/4. htm, last accessed on November 22, 2107.

Kon, Igor 1993. Nesvoevremennye razmyshleniia na aktual'nye temy. [Untimely Thoughts on Pressing Topics.] Etnograficheskoe obozrenie, No. 1, pp. 3-8. Available at http:// journal.iea.ras.ru/archive/1990s/1993/1.htm, last accessed on November 22, 2017.

Markov, Gennadii 1992. O bednoi nauke zamolvim slovo. [Let us Support the Poor Science.] Etnograficheskoe obozrenie, No. 5, pp. 3-7.

Semenov, Iurii 1998. Predmet etnografii (etnologii) i osnovnye sostavliaiushchie ee nauchnye distsipliny. [The Research Focus of Ethnography (Ethnology) and Its Main Constituent Disciplines.] Etnograficheskoe obozrenie, No. 2, pp. 3-17.

Shnirelman, Viktor 1992. Nauka v usloviiakh totalitarizma. [Science under Totalitarianism.] Etnograficheskoe obozrenie, No. 5, pp. 7-18.

Sokolovskiy 1993 = Sokolovskii, Sergei. Etnograficheskie issledovaniia: ideal i deistvitel'nost'. [Ethnographic Research: Ideal and Reality.] Etnograficheskoe obozrenie, No. 2, pp. 3-13; No. 3, pp. 3-14.

Sokolovskiy 2003 = Sokolovskii, Sergei. Chetvert' veka rossiiskoi antropologii: 1975-2000. [A Quarter of a Century of Russian Anthropology: 1975-2000.] In: A. Piskoppel et al. (eds.) Etnometodologiia: problemy, podkhody, kontseptsii. [Ethnomethodology: Problems, Approaches, Concepts.] Moscow: Rossiiskii nauchno-issledovatel'skii institut kul'turnogo i prirodnogo naslediia, pp. 136-159. Available at http://old. iea.ras.ru/publications_new/ethnomethodology/pdf/em-9/136-159.pdf. 
Sokolovskiy 2009 = Sokolovskii, Sergei. Rossiiskaia antropologiia: illiuziia blagopoluchiia. [Russian Anthropology: An Illusion of Wellbeing.] Neprikosnovennyi zapas, No. 1, pp. 45-64. Available at http://magazines.russ.ru/nz/2009/1/s4.html, last accessed on November 23, 2017.

Sokolovskiy 2011 = Sokolovskii, Sergei. V tseitnote: zametki o sostoianii rossiiskoi antropologii. [In a Zeitnot: Notes on the State of Russian Anthropology.] Laboratorium: Zhurnal sotsial'nykh issledovanii, No. 2, pp. 70-89. Available at https://cyberleninka.ru/ article/v/v-tseytnote-zametki-o-sostoyanii-rossiyskoy-antropologii, last accessed on November 22, 2017.

Tishkov, Valeri 1992. Sovetskaia etnografiia: preodolenie krizisa. [Soviet Ethnography: Overcoming the Crisis.] Etnograficheskoe obozrenie, No. 1, pp. 5-20.

Tishkov, Valeri 2002. Gorizonty rossiiskoi etnologii. K 70-letiiu Instituta etnologii i antropologii RAN. [The Horizons of Russian Ethnology: Published with Regard to the 70th Anniversary of the Institute of Ethnology and Anthropology, Russian Academy of Sciences.] Novaia i noveishaiia istoriia, No. 5, pp. 3-18.

Tishkov, Valeri \& Pivneva, Elena 2010. Etnologicheskie i antropologicheskie issledovaniia v rossiiskoi akademicheskoi nauke. [Ethnological and Anthropological Research in Russian Academic Science.] Novaia i noveishaia istoriia, No. 2. pp. 3-21.

Ventsel, Aimar \& Struchkova, Natalia 2016. Can We Talk about Post-Soviet Science? Folklore: Electronic Journal of Folklore, Vol. 63, pp. 121-126. http://dx.doi. org/10.7592/FEJF2016.63.discussion. 


\section{IN MEMORIAM}

\section{CHRISTIE DAVIES}

\subsubsection{1 - 26.08.2017}

The field of humour research has experienced a painful loss with the death of Christie Davies, the distinguished Welsh sociologist, one of the best specialists of ethnic humour, Professor Emeritus of the University of Reading. His main research interests were in the areas of criminology, sociology of morality, censorship, and humour. He published 13 books, including Ethnic Humor around the World (1990), Jokes and Their Relation to Society (1998), The Mirth of Nations (2002), and Jokes and Targets (2011), as well as numerous articles, one of which, titled "Jokes as the Truth about Soviet Socialism" was published in Folklore: Electronic Journal of Folklore (http://folklore.ee/ folklore/vol46/davies.pdf) in 2010.

He was a visiting scholar in India and the United States, and gave lectures and presentations on humour in many European countries. Christie's lectures were always greatly anticipated and offered intriguing viewpoints. In his work about jokes and society he stressed the possibilities and necessity of humour research, showing that jokes can point to great sociological changes, just as they did with the fall of the Soviet Union.

He was well connected with the Estonian folklorists, giving lectures at the University of Tartu and taking part in conferences organised in Estonia, as well as writing articles for collections edited here.

We have lost a good friend and a kindred spirit.

Piret Voolaid 


\section{NEWS IN BRIEF}

\section{THE 29TH INTERNATIONAL SOCIETY FOR HUMOR STUDIES CONFERENCE IN MONTREAL, CANADA}

On July 10-14, 2017, practitioners and researchers of humour were invited to share their most recent experience and results concerning humour studies at the 29th ISHS Conference in Montreal in Québec, Canada (see the webpage of the event, https://ishs2017-montreal.uqam.ca/en/home/). This conference was organised by professor JeanMarie Laforturne and Dr Christelle Paré, Postdoctoral Fellow at the Centre for Comedy Studies Research (Brunel University London) and hosted by the University of Quebec in Montreal (Université du Québec à Montréal; UQAM), in collaboration with the Observatoire de l'humour. During the five days packed with academic discussion and social events, the participants tried to find out about humour's je ne sais quoi, attempting to define and describe the power that humour holds.

For many reasons, Montreal was a perfect place to host a humour conference. Located in the heart of the Quartier des spectacles, an international centre for artistic creation, UQAM offered an opportunity for the conference participants to access a variety of cultural activities, venues, and shows just a short walk away. The world-famous comedy festival, Just for Laughs, was going on parallel to the conference and in the evenings the streets were packed with shows and spectacles performed by circus artists, comedians, and actors.

The annual event is frequented by researchers of an interdisciplinary background, who try to tackle humour-related issues from various angles. One of the aims of this convention is to bring representatives of different disciplines (linguists, folklorists, social scientists, psychologists, historians, etc.) together and help them find a common language to describe the complicated phenomenon of humour in order to contribute to a general understanding of how to define humour, how it works, and how to study it.

The president of the ISHS, Delia Chiaro, stressed in her opening address on the evening of July 10 that it is these simple questions - where does humour come from and why do we need it in the first place - that are the central tenets in the field of humour research. Pursuing these questions might result in fascinating discoveries that benefit from the contribution of the numerous disciplines.

The binding framework of the conference, however, was set by Sharon Lockyer, professor of communication and sociology from Brunel University London. In her plenary lecture, she looked back at her contacts with humour research during the past 20 years that she has been active in the field, and gave an elegant overview of the history of humour research, thus positioning its place in the humanities throughout this period. In the 1970s, psychologists lay the ground for the scientific study of humour, but nowadays the psychological viewpoint does not precede over the other possible angles; instead, different disciplines seem to contribute equally in their own ways. Folklorists, for example, have an important role to carry in the scientific study of humour, because they have access to longitudinal data that can prove or refute hypotheses posited by sociologists or psychologists as they have access to centuries of folkloric data. Lockyer referred to three 
main reasons not to take the study of humour lightly: 1) humour is not trivial; 2) humorous is not the opposite of serious; 3 ) taking humour seriously is not anti-humour. Even though it is not yet possible to defend one's degree in the field of humour studies, and humour still remains the object of a number of separate disciplines, the International Society for Humour Research has brought into life international summer schools as well as published humour encyclopaedias and international volumes of articles in order to shape this field into an interdisciplinary, yet coherent area of research.

During the five days, the conference participants could attend more than 170 presentations grouped thematically into panels and sessions. The International Association for the Study of Humour, for example, organised a set of sessions that delved deeper into the philosophical underpinnings of humour and joke. Next to that, there were separate panels dedicated to Persianate humour, or humour and the media, literature, and art. Sessions discussed humour from the gender studies point of view - both women's and men's studies framework. Humour in social media proved to be a burgeoning field. An entire conference day was dedicated to political humour. The day began with a plenary section that analysed topical humour: Brex(sh)it jokes (Delia Chiaro), jokes about the South-African president Jacob Zuma and his representation in different comic genres, e.g. caricatures and stand-up (Debra Aarons), references to taboo topics in the speeches of Donald Trump (Chiara Bucharia), and kinetic and memetic warfare in the US presidential elections (Anthony Mitzel). Humorous forms of expression allow for conveying political and ideological messages, even though the messages coming from competing sources can give a totally different (albeit humorous) picture.

Estonian humour research was represented by four scholars. Liisi Laineste gave a presentation about ethnic humour in Estonia as part of the panel on transcultural humour lead by Jean-Marie Laforturne. She analysed the trends of globalisation and localisation of the material that covered more than a century of jokelore. Piret Voolaid's paper was a part of a session on humour and identity. She focused on the connotational field of the phrase "Estonian national sports", analysing internet media and memes as well as her survey results. She found that fields of sport that are based on historical cultural traditions (e.g. wrestling and weight-lifting; cross-country skiing, etc.) have a large group of fans and followers in Estonia. In those fields, Estonian sportsmen have acquired higher positions in international competitions, and thus the fields have been used as building stones of national identity and carry a role in related narratives. Voolaid also pointed out the ironical rhetoric use of these phrases (Estonian national sports is armchair sports, alcoholism, "throwing" despair ( throwing a javelin, etc.)). Certain national behavioural patterns, entrenched habits and stereotypes are ridiculed through the use of a playful phrase. In the same session, Anastasiya Fiadotava (PhD student at the University of Tartu) presented her paper on dyadic humour in Belarusian couples, basing her analysis on the theoretical insights of Elliott Oring, Gary Alan Fine, and Christie Davies. In the panel dedicated to humour and technology, Mikhail Fiadotau (doctoral student and junior research fellow at Tallinn University) showed how humour is used in video games to attract attention and create in-group humour among gamers.

ISHS conferences have established a tradition of awarding young scholars. This year's emerging scholars were Ying Cao from Australia (the recipient of the Don and Alleen Nilsen award with her study on constructing gender identity in Chinese sitcoms), Shuming Bai from Singapore (who studied humorous devices in the speech of Singaporean prime 


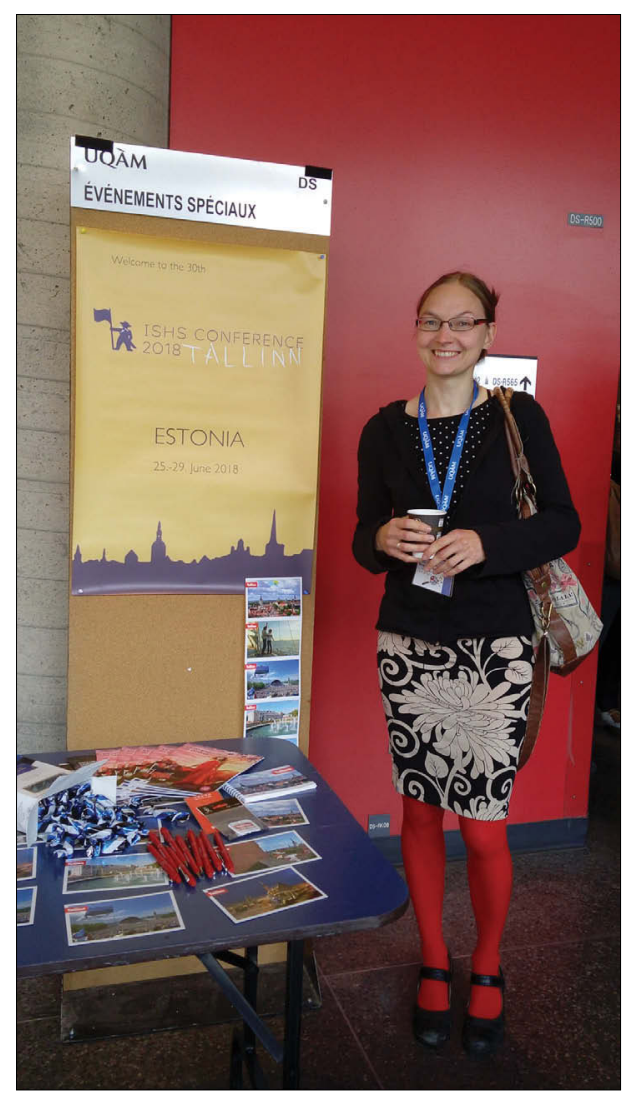

The 30th ISHS annual conference will be held in Tallinn, Estonia. The conference convener Liisi Laineste is Senior Research Fellow of the Department of Folkloristics at the Estonian Literary Museum. Photograph by Piret Voolaid.

minister, held on August 2, 2016, during a dinner in the White House), and Antony Mitzel from Italy (focusing on jokes about Italians in memes and advertisements).

Apart from paper sessions, there were also symposia, open fora, practical workshops, and other formats that addressed, among other issues, therapeutic aspects of humour. There were several practitioners who explained the physical and psychological benefits of "doctor clowns" in hospitals. A separate session addressed the post-traumatic humour of rape victims.

This year's participation in the ISHS conference in Montreal was especially important for the Estonian research team because the 30th International Society for Humor Studies conference will take place in Tallinn (see the conference webpage at https://www.folklore.ee/rl/fo/konve/ishs2018). Conference convener Liisi Laineste held a promotion speech at the ISHS members' meeting on July 13. Throughout all the conference days in Montreal, there was an ISHS 2018 booth set up for anyone interested in more information about the next conference or its location. Piret Voolaid, Liisi Laineste, Anastasiya Fiadotava, and Mikhail Fiadotau talked about Tallinn and Estonia, and distributed materials connected with the destination. Hosting the next ISHS conference in Tallinn will undoubtedly be an important event in next year's academic calendars for a large interdisciplinary crowd of humour researchers. At the same time, it is an opportunity for the Estonian folklorists to show their professionalism and academic accomplishments to an international audience.

Participating in the ISHS 2017 conference was supported by the Estonian Ministry of Education and Research (IUT 22-5), by the European Union through the European Regional Development Fund (Centre of Excellence in Estonian Studies, TK 145 - CEES), and by the Estonian Cultural Endowment.

Piret Voolaid, Liisi Laineste 


\title{
NIKOLAI ANISIMOV DEFENDED HIS DOCTORAL THESIS ON THE UDMURTS' BIRTH AND BURIAL CUSTOMS
}

\author{
Nikolai Anisimov. Dialog mirov v matritse kommunikativnogo povedeniia udmur- \\ tov. Dissertationes folkloristicae Universitatis Tartuensis 26. University of Tartu \\ Press, 2017. 384 pp.
}

On November 10, 2017, Nikolai Anisimov defended his doctoral thesis titled Dialog mirov $v$ matritse kommunikativnogo povedeniia udmurtov (Dialogue between the worlds through the lens of Udmurt communicative behaviour) at the University of Tartu. The thesis is a voluminous monograph, dwelling upon conceptions, beliefs, and ideas related to the Udmurts' birth and burial customs. The selected point of view - a dialogue between the worlds of the living and the dead within communication - enables the author to present his material systematically and is justified, considering Udmurt beliefs, as even today Udmurt birth and burial customs feature communication with the otherworld. It is namely a dialogue as, in addition to commemorating the dead on holidays as well as other similar acts directed from the living to the dead, the behaviour of many Udmurts, especially from the older generation, is influenced by the belief that the dead are able to actively find contact with the living and affect their life and activity.

In the introductory part of the dissertation, the author explains his ideas about the matrix of communicative behaviour, about the dialogue between worlds, and the ethnonym 'Udmurts', by doing so establishing a certain framework for the dissertation. He also gives an overview of his research object and domain and sets the objective - to show the peculiarities of the worlds' dialogue as ethnopsychological and behavioural stereotypes within the framework of the traditional imagery of time and space. He proceeds to introduce the novelty of his approach, highlighting its temporal-spatial borders, and discusses his research methods, the most important of which are semiotic and comparative-juxtaposing methods. The introductory part ends with a detailed summary of the research previously conducted in the domain.

The first two chapters of the dissertation provide an overview of the Udmurts' traditional worldview with the most important loci and borders between them, and dwell upon contacts between different worlds within the cycles of day and night, week, and year. Although this part of the dissertation largely repeats the viewpoints formerly presented by some other scholars (e.g. Vladimir Vladykin, Tatiana Vladykina, Elena Popova, Tatiana Minniyakhmetova, Ranus Sadikov, Galina Glukhova, etc.), the chapter is necessary for understanding the following parts of the dissertation and also involves the author's fieldwork materials.

The third chapter of the dissertation is dedicated to the beliefs related to the birth of a child, beginning with more general beliefs and ending with the imagery influencing behaviour during the delivery and the time after it. The role of the dead in relation to a child's birth, development, and illnesses, as well as the possible intervention of the supernatural world (exchanged or exceptional child), is shown in the context of an active dialogue between the worlds.

The fourth chapter gives a detailed overview, within the framework of the worlds' dialogue, of the beliefs influencing burial customs, starting from the imagery related to death to a detailed description of the procedures performed on the deceased as well as 
their religious reasons. At the core of the chapter is the deceased's arrival in the 'land of the dead' and the role of the dead ancestors in it, as well as the mourners' return to the 'land of the living'. This chapter also includes plenty of the author's fieldwork materials.

As a logical end to the dissertation, the fifth chapter discusses the period after the funeral - communication with the deceased, the visitations of the dead to the living, and the customs related to commemoration.

Nikolai Anisimov's dissertation is supplemented with a detailed list of informants and a dictionary of relevant Udmurt expressions (a hundred keywords in all). One of the appendixes presents a selection of funeral songs. As a researcher of Udmurt beliefs, I can say that this is the most systematic, detailed, and interesting treatment of birth and burial customs ever written on this topic. The rich material collected by the author, partly formerly unpublished, adds to the value of the dissertation.

Aado Lintrop 


\section{BOOK REVIEWS}

\section{CONTEMPORARY LEGENDS IN SLOVENIA}

\section{Ambrož Kvartič. Pa se je to res zgodilo? Sodobne povedke $v$ Sloveniji. Ljubljana: Filozofska fakulteta, 2017. 272 pp.}

The monograph titled $\mathrm{Pa}$ se je to res zgodilo? Sodobne povedke $v$ Sloveniji (So Has This Really Happened? Contemporary Legends in Slovenia) is the first book dedicated to the topic of Slovenian contemporary legends, and can therefore be considered as a turning point in this genre in Slovenian folkloristics. The book was written on the basis of Kvartič's doctoral dissertation on contemporary legends in Slovenia.

The book is divided into two parts: in the first, largely theoretical part the author discusses key concepts for research, recognition, analysis, and general understanding of contemporary legends worldwide (mostly in the Anglo-Saxon world) and in Slovenia. The theoretical part is divided into eight chapters and comprises the majority of the book. It starts with an introduction in which Kvartič introduces his methodology and research question, explaining what contemporary legends can be found in Slovenia, how and which processes influence these materials, and who tells contemporary legends, to whom, and why these legends are told. He tries to answer these questions from theoretical and empirical, textual and contextual, comparative and interpretative, emic and etic viewpoints, and illustrates his findings with material collected during fieldwork. The main methodology for collecting contemporary material was fieldwork conducted between 2010 and 2014, which included interviews, observation, and organization of storytelling events (3-10 people), which were audiorecorded. The author focused on cities with more than 10,000 inhabitants.

The introductory part of the book is followed by theoretical issues with a comprehensive overview of previous theoretical research on contemporary legend in Slovenia and abroad. He first introduces definitions of contemporary and urban legends, emphasizing that such legends spread mainly in urban environments and to a somewhat lesser degree in rural ones. He understands contemporary legends as "incredible, bizarre, unusual, disgusting, frightening, terrifying, but also humorous stories that continually emerge and vanish in daily conversations and are repeatedly installed in the real experimental world of their narrators". Kvartič brings into initial focus the terminology issues that have so far remained unresolved. He uses the term 'contemporary legend'; however, he does not ignore the term 'urban legend', which he introduces as a genre, a referential framework, and metonymy, and as a signifier of identity.

In terms of genres, types, and intertextuality Kvartič finds contemporary legends as specific and recognizable phenomena. He brings forth also examples of the use of contemporary legends in screenplays, comic texts, and fine arts. When discussing typology, Kvartič emphasizes that although motifs might be similar, there is a huge problem with linguistic and cultural differences, and therefore the typology presents a specific challenge. 
The author turns special attention to the synchronic and diachronic migration of motifs in contemporary legends as well as to the reality and beliefs. His findings are predictable: most of the motifs are to be found in different cultural and language areas. Contemporary legends travel through time and place, through languages and different places of identifications, and therefore both synchronic and diachronic migrations are extremely vivid.

In the second part of the book, titled "Contemporary Legends in Slovenia: Examples with Interpretation”, Kvartič puts material into focus. Considerable attention is devoted to interpretation as a process of finding the meaning, which also gives us a deeper insight into the culture and underlines the characteristics of the contemporary legend: they change and adapt to concurrent history and chaotic social environment much faster than other folklore genres. He presents the material of contemporary legends, that was collected during fieldwork, and categorizes it by themes: The Vanishing Hitchhiker, Trickster in Contemporary Legend, The Failed Stag Party, The Couple Caught in Flagrante Delicto, Tourist Experience, Foreigners / Other in Contemporary Legends, etc. In all the themes Kvartič aims to find variations, a general motif, rationalization of legends, localization of the migration motif, and socio-historical context.

As a finalizing conclusion, Kvartič states that contemporary legends constitute a source for never-ending research - not only because of their huge variety but also because they change and adapt the stories to the context.

Contemporary legends were neglected in Slovenian folkloristics for a long time; therefore, this book, with its strong theoretical and highly professional approach, fills in a big gap in Slovenian folkloristics. But not only that - the book is also highly inspiring and interesting for a wider readership as the language the author has used is very fluent and vivid, with many examples and outlines of stories. Due to its good theoretical insight into the scholarship of the subject, it also provides valuable support to all researchers of contemporary legends and contemporary folklore in general.

Saša Babič

\section{STILL ECOLOGICAL MIGRATION? AN EWENKI CASE}

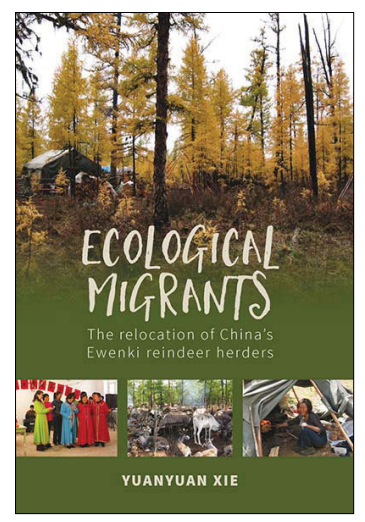

Xie, Yuanyuan. Ecological Migrants: The Relocation of China's Ewenki Reindeer Herders. New York \& Oxford: Berghahn Books, 2015. 220 pp.

The book under review is one in the already impressive list of the latest publications based on socio-anthropological research among the Ewenki - a relatively large but dispersed Tungusic-speaking ethnic group, which still retains the practice of reindeer herding in a number of places in Siberia (Russia), Mongolia, and China. Every year, for the last 6-7 years, one or two monographs on the Ewenki are published, which almost immediately evoke a lively response in the academic environment (Funk 2014; Napol'skikh et al. 2014; Ventsel 2014; Mamontova 2016). 
The monograph of the Chinese researcher Yuanyuan Xie is dedicated to a small group of the Ewenki of China, known in the literature as Yakuts (Yakut Ewenki), Reindeer Ewenki, Reindeer Using Tribe, and other similar names (using the word 'reindeer'), as well as Aoluguya Ewenki Hunters. The latter term, speaking of exoethonyms, is by far the most accurate, since it determines the ethnic identity of the group (Ewenki), and the place of their compact residence (Aoluguya, or Ao Township, Genhe County, Inner Mongolia Autonomous Region, China). However, it is certainly doomed to failure when it comes to defining the specifics of the economic activities of this group with one concrete term (it does not matter whether it is reindeer herders or hunters). And it is not only because the mono-economic group is, in principle, difficult (perhaps impossible) to imagine, but also because in the case of this group of Ewenki we are dealing with a marked change in all patterns of economic activities over the past 60 years: from the taiga hunting using the deer for transportation purposes, fishing, and gathering, up to the marginal position of the inhabitants of the stationary settlement, depending more on the state guardianship than on their own labour.

Xie's work is a kind of complement to the earlier, also published in 2015, collective work, Reclaiming the Forest: The Ewenki Reindeer Herders of Aoluguya, edited by Åshild Kolås and Yuanyuan Xie (see review in Mamontova 2016: 141-143), but at the same time this is an entirely independent study, with its own logframe for the presentation of the material, and in general is purely an author's study, based on a long stay in the field, and literally on every page imbued with a touching authorial attitude to the object of her scientific interest.

The monograph titled Ecological Migrants consists of a general introduction and five chapters, the last of which serves as a sort of detailed conclusion, as well as a list of literature and index.

The first chapter, "Living with Ewenki Hunters" (pp. 14-55), is entirely based on the description of the field experience (from September 2003 to October 2004) of the author who came across the "exotic culture" (p. 11), and the complexities she overcame herself and with the help of informants. Although sometimes the text is alarming, especially after the reader has learnt how the author prepared for her long fieldwork ("after briefly browsing through books about Ewenki history and their local traditions and customs, I packed up my things ..." (pp. 13-14)), on the whole, it nevertheless redeems itself by being open and frank, and thus it sets up a trusting attitude to what the author is going to tell forth in the future. The abundance of voices of informants inscribed in the narrative strengthens this trust.

The second chapter, "The Culture of Reindeer Ewenki and Historical Settlements" (pp. 56-84), gives a general idea of the main (from the point of view of the author) characteristics of the Ewenki society and its traditional culture (in the text they are called "historical characteristics", p. 60), and also reveals, albeit briefly, the background of the ecological migration of 2003. The large first section of the chapter includes paragraphs titled "Population and Living Environment, Traditional Lifestyles, Ethnic Characteristics, Religious Beliefs", and finally, separately, "Views on Life and Death". Despite the presence, in some cases, of important ethno-historical information, the author's comments would also be beneficial for the logic of the section. The text itself, in a number of cases, also raises questions. There are, for example, timeless adverbs such as originally, later, in the past (however, such 'definitions' of time are found throughout the text; see, 
for example, p. 186), as well as terms not quite familiar in modern anthropological language, such as "early tribes" (p. 65), or stylistically awkward, such as "[they] believed in shamanism" (p. 66). The last section of the chapter, "Historical Settlements under New China", shows the whole tragedy of the small ethnic group that has been exposed, it is difficult to say otherwise, to the "loving care of the (Communist - D.F., S.D.) Party and government"1.

The author consistently expounds the history of the first two migrations of this group of the Ewenki, to Qiqian (Rus. Ust'-Urov) along the Argun River in 1957-59 and from Qiqian to (Old) Aoluguya in 1965. Nevertheless, without focusing on this, the author was able to show how great was the strength of the collective irresponsibility of the country's governing bodies of the time; for example, she could not find in the published sources a detailed description of the event (the so-called Surrender-to-Revisionism-Treason Incident), which, according to the Ewenki themselves, became the reason for the second resettlement, and therefore Xie had to rely entirely on the memories of her informants.

The third and fourth chapters, "Ecological Migration Path" (pp. 85-124) and "Postmigration Issues" (pp. 125-182), can be considered as the main part of the study under review. In the third chapter, the author consistently presents the views of officials and ordinary Ewenki on the reasons for the origin of the resettlement plan and on the very process of preparing and implementing this plan, including a description of the celebration of the success of the whole event, which took place on the 40th day after the resettlement, on September 28, 2003. The chapter concludes with a brief description of the social transformations that have occurred among the Ewenki who found themselves in New Aoluguya, in comparison with what is known about the inhabitants of Old Aoluguya. The about 260-kilometre-long path within the same province, Genhe County, led, as can be seen from the author's data, to a significant transformation of the social structure of society. The next chapter, like the previous one, is filled with the author's materials. These materials show what opinions about resettlement and related problems different participants in the process had, what contradictions and conflicts there were, what measures the local government took to resolve the problems, in particular, in reindeer husbandry and, especially, in the process of cutting and marketing reindeer antlers. Long stay in the field allowed the author to reveal a number of essential details. For example, Xie managed to find out that cutting reindeer antlers and purchasing them from the Ewenki for "medical use" was always a kind of profanity, because "according to the traditional Chinese Medicine Pharmacopoeia, reindeer antlers cannot be used as a medicine" (p. 180). These antlers were purchased solely for mixing with the red deer antlers (whose uncalcified antlers are called velvet antlers), which allowed to increase the overall mass of antlers and to sell them at the price of red deer antlers (p. $178 \mathrm{ff}$.). We can only guess why the local authorities decided to support the process of cutting and purchasing deer antlers.

No less important are some of the author's remarks, sometimes unexpected and with no detailed explanations, which, however, seem to be important for understanding the essence of the whole process, which has been defined as "ecological". Thus, it turns out that in order to ensure the resettlement of 62 Ewenki households to New Aoluguya (previously called Sanchejian), local authorities evicted (yes, indeed!) more than 100 families from there - they were "primarily migrant workers, drifters, or family members of the township government employees" (p. 120), to whom compensation was paid and who found housing in other settlements. However, we cannot say that we 
as readers were satisfied with the explanation proposed by the author: "It is evidence of the government's attempt to provide special assistance to this [Ewenki - D.F., S.D.] ethnic group" (p. 115). What this confidence is based on and why the good of one group of people should be provided by eviction to another group, is not explained in the text.

Even more important for characterizing the process of ecological migration is a small fragment of the text on pages 95-97, almost entirely represented by the translation of one of the administrative documents and the comments of an anonymous official, as well as a couple of other comments, scattered all over the book. Judging by these comments, this process of resettlement was only a convenient way for local officials who, using the existing state environmental and socio-economic programs (in particular, the Grand Western Development Plan, proposed in 2000 by the Central Committee of the party; p. 12) and the rhetoric of the preservation of ecology in the western regions of the country (it is worth noting that Genhe County is not to the west, to put it mildly; it is the extreme north-east of Inner Mongolia), as well as the rhetoric of "development", could thus fit in one of the state programs and obtain additional funding for the region. This migration, in fact, had nothing to do with the environment (p. 97). The information, given by the author in one of the notes to the third chapter, looks as a mockery of people - a toy in the hands of Big Brother:

The county government clandestinely sold the old Aoluguya site to a real estate development company. Ironically, the land and ecosystem "protected" through the ecological migration plan will now be used by the real estate company to open a for-profit trophy-hunting ground for rich urbanites. They will undoubtedly claim this will stimulate economic development. (p. 124)

The final chapter, "Aftermath and Future" (pp. 183-210), is a summary of the author's reflections on the essence of the occurred ecological migration, and its role in the preservation or transformation of the Ewenki culture, and also, in general, about the meaning of the planned modernization.

In general, the book makes an ambivalent impression. On the one hand, it is certainly important for a better understanding of the ethnic policies that have been and are being implemented in China and, of course, it is significant in terms of bringing a good amount of relatively fresh field material into indigenous studies. On the other hand, there remain questions concerning, first, the language of description in which the party and/or the government are represented as a kind of collective body that can believe, initiate or develop plans, take steps, assist, etc.; as it seems to us, that is why some of the passages in the text resemble the style of newspaper texts in which argumentation is not required; and secondly, the lack of comparative material on other small ethnic groups of China and/or the Ewenki in other regions of Asia, ${ }^{2}$ which would certainly help to better understand the social processes reviewed by the author, and place the material in the context of contemporary debates, for example, in the field of indigenous studies, Siberian anthropology, applied or practising anthropology, migration studies, and, particularly, forced migration. And yet we would recommend reading this book. It will be extremely interesting to everyone who studies other groups of the Ewenki, or more broadly - ethnic groups that are under the influence of the state and/or business. Being filled with unique field materials, this work itself can become a source for further comparative studies of a similar orientation. 


\section{Acknowledgements}

Written within the framework of the project "Man in a Changing World: Problems of Identity and Social Adaptation in History and at Present" (the RF Government grant No. 14.B25.31.0009).

Dmitriy Funk, Moscow State University / Tomsk State University

Seil Djanyzakova, Tomsk State University

\section{Notes}

1 Quotation from the monograph of 1994 by F. Kong, given in the book under review (p. 76).

2 The only exception is the seven lines in the fifth chapter, referring to the example of the Oroqen ethnic group in connection with reflections on forced lifestyle changes (p. 189). However, reference to other reindeer-breeding groups is also found in the introduction; although it is accompanied by a reference to individual publications of anthropologists, it is too general and contains inaccuracies (for example, the Buryats and Eskimos are listed here as reindeer breeders) (p. 4).

\section{References}

Funk, Dmitriy 2014. Book review. T. Safonova \& I. Sántha. Vstrechi na evenkiiskoi zemle: kiberneticheskaia antropologiia Baikal_skogo regiona. [Meetings in Evenki Land: A Cybernetic Anthropology of the Baikal Region]. St. Petersburg: Aleteiia, 2013. 176 pp. Siberian Historical Research, Vol. 2, pp. 134-137.

Mamontova, Nadezhda 2016. Book review. Åshild Kolås \& Xie Yuanyuan (eds.) 2015. Reclaiming the Forest: The Ewenki Reindeer Herders of Aoluguya. New York \& Oxford: Berghahn, 2015. 198 pp. Nomadic Peoples, Vol. 20, pp. 141-143. DOI: 10.3197/np.2016.200109.

Napol'skikh, Vladimir \& Sokolovskii, Sergei \& Abashin, Sergei \& Istomin, Kirill \& Funk, Dmitrii 2014. Diskussiia po knige A.A. Sirinoi "Evenki i eveny v sovremennom mire: Samosoznanie, prirodopol'zovanie, mirovozzrenie”. [Discussion of A. Sirina's book Evenki and Eveni in the Modern World: Identity, Nature Relations, World View.] Moscow, 2012. EO-Online, 2, pp. 193-220. Available at http://journal.iea. ras.ru/online/2014/2014_2_193_220_Sirina.pdf, last accessed on October 23, 2017.

Ventsel, Aimar 2014. Three Books about Evenki. Folklore: Electronic Journal of Folklore, Vol. 56, pp. 169-173. Available at http://www.folklore.ee/folklore/vol56/b03.pdf, last accessed on October 23, 2017. 


\title{
LIVING ORAL HISTORY TRADITION IN THE 21sT CENTURY EUROPE
}

\author{
Marilena Papachristophorou. Myth, Representation and \\ Identity: An Ethnography of Memory in Lipsi, Greece. New \\ York: Palgrave Macmillan, 2013. 198 pp.
}

This is a beautifully and slightly philosophically written book about community identity building in a society with a strong oral tradition. Marilena Papachristophorou is Assistant Professor of Folklore at the University of Ioaninna, Greece, and has published a monograph based on her fieldwork on a small Greek island, Lipsi, where she has conducted fieldwork over a decade. Over this time period the author was able to observe changes in the local community and how these changes reflected in local narratives that constitute the basis for identity building on the island. Lipsi is a small Greek island with one village, with a population of less than seven hundred people. Traditionally, inhabitants of the island have been engaged in fishery, agriculture, and tourism. The first inhabitants of the island were monks and until today the Monastery of Patmos possesses a big part of the island.

The focus of the book is well summed up on page 13: "In the following chapters I shall attempt to explore the oral tradition of the island as I perceived and recorded it over these ten years, often "working" within entire families and "tracking" narratives and worldviews across three or four generations. [...] The presentation of my ethnography and the relevant anthropological interpretation are structures along three areas: (1) the history of the island according to collective representations; (2) religion experienced, both as narrative and as ritual; and (3) everyday narrative occasions." The main thesis is presented on page xi: "Symbols, as verbal representations of physical objects, can obviously survive in narrative and cultural practices much longer than religions themselves and even when the ritual contexts [...] no longer exist." Therefore, not unsurprisingly, the author leans heavily on the structuralist approach, looking at narratives and symbols as the "total fact" of Claude Levi-Strauss.

The tone is set in the first chapter which is dedicated to the Hellenic legend about Odyssey and of how Greek legends about the goddess Calypso and wanderings of Odysseus or Ulysses are related to the island, but also a template of the narrative of the creation of the community. Marilena Papachristophorou shows that the myth of the creation of Lipso, Christian by its nature, repeats elements and narratives from the Odyssey, and that geographically several key events from both narratives take place in the same locations. Throughout the book she refers to Elias or Old-Lios, who is the ancestor of the people from Lipso, but at the same time also to a Trickster whose biographical facts draw from Ulysses' short stay in Lipso. Chapter two compares Elias' story with that of Ulysses and shows how the origin of the people is connected with how and when they received their allotments of land from the monastery. The author concludes that the history of the island is not merely facts but a shared worldview of the islanders (p. 45). 
A big part of the book is dedicated to how local cosmogony is reflected in landmarks and toponymes. To sum it up, the island of Lipso is viewed as a polarised world - there is human territory and wilderness. Wilderness is inhabited by devils and the human sphere by saints. Saints in local history are personified and related to particular families. Myths about saints are linked to legends of hidden treasures and events of deceased ancestors. As it appears, the islanders' relationship with the environment is often defined through visions and miracles, which mark certain life events (like birth of children) but simultaneously symbolise a bond with a particular saint. In chapter four the author shows that life in Lipsi is a constant struggle between "impure land" and the human space, the appropriation of wilderness is linked with good and bad supernatural powers and therefore has a transcendent dimension. The author also talks about how different places become meaningful when they are given names that connect them with concrete persons or events. This approach is similar to that discussed by Keith Basso among Western Apache or Alex King among Koryaks. In Lipso, such personification of the landscape is mainly related to the appropriation of the land from the wilderness or to some key events in the life of an ancestor. In one way or another, such a social bond to the space symbolises land ownership. This is a social construction of landscape but the strength of such a tradition in modern Greece is surprising.

In chapter six Papachristophorou comes back to everyday practices, talks about people, and demonstrates the strength of the community's oral culture. Narratives and myths are transmitted and reproduced through chatting over coffee or at family celebrations. Analysing changes from the past decade, the author shows how communal rituals (dancing, celebrating, visiting the cemetery) are essential in creating a sense of solidarity and unity within the villagers. The author, however, argues that communal rituals are not to be understood as a revitalisation of traditions but as renewing the imagined community. When rituals remain the same, then their meaning and related personal or communal narratives are in a constant flux. Every generation relates different stories to dances and other celebrations and these commonly shared narratives renew the social bond between islanders. Additionally, chapter seven discusses how long traditions help to create continuity and history of the community.

What renders special value to the monograph is the auto-ethnographic approach of the author. She discusses how she and her son became related to the community, what they felt and how they reacted to things. The islanders are depicted in a way the reader feels the atmosphere in the village and the warmth of community rituals. Apart of being an interesting read, the book made me wish to visit Lipsi as a tourist.

As a Siberianist, I found the book interesting and necessary due the fact that similar processes can be observed everywhere. In light of the culture of narratives in Lipsi we should revise the concept of modern traditional culture since it has been related to non-Western culture. As the book shows, we can conceptualise the traditional culture through Christianity and still find enough material to compare it with non-Christian and non-European people. This book is highly recommended not only to folklorists but also to anthropologists and even to a wider range of social scientists, such as political scientists. Understanding various ways of establishing and maintaining local identities is helpful in creating a bigger picture when you study, for example, nation building or social movements. 


\title{
AN ANTHROPOLOGY OF OUTER SPACE: PLANETARY IMAGINATION AND PLACEMAKING PRACTICES
}

\author{
Lisa Messeri. Placing Outer Space: An Earthly Ethnography \\ of Other Worlds. Durham \& London: Duke University \\ Press, 2016. 248 pp.
}

There's been a lot of great work by NASA and other organizations in early exploration of Mars and understanding what Mars is like, where we can land, what's the composition of atmosphere, where is the water or ice... But we need to go from these early exploration missions to actually building a city.

(Elon Musk in September 2016)

The above excerpt from Elon Musk's lecture at the Inter-

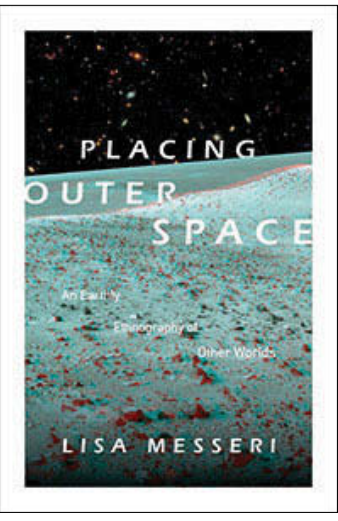
national Astronautical Congress in Guadalajara, Mexico, on September 26, 2016, reveals his intentions to move from the research of Mars to the colonizing of the planet, also demonstrating the engine, fuel tanks, and other elements of the interplanetary ship his company SpaceX is working on. The book by Lisa Messeri, Placing Outer Space: An Earthly Ethnography of Other Worlds, reveals the transformation in modern astronomy and planetary science which makes this shift possible - the distant planets in the solar system and around distant stars are not abstract space objects anymore, but rather concrete places that humans could inhabit one day.

The book represents an important step in anthropology, approaching a new field of modern society - space exploration. Messeri affiliates to "a small field that can be called the "social studies of outer space", seeking to understand what the cosmos can tell us about ourselves. She refers to the works of D. Valentine, V. Olson, and D. Battaglia as founders of this new field, who explicitly argue about the need for an anthropological approach to outer space as "a crucial site for examining practices of future imagining in social terms, and for anthropological engagement with these practices" (Valentine \& Olson \& Battaglia 2009: 11). The field could be considered as a branch of anthropology of science, which emerged more than forty years ago, becoming one of the engines of the profound transformation in social sciences today. However, the study of outer space touches the very roots of anthropology as a science - simply because in a strange way it resembles the foundational studies of 'primitive' and traditional cultures, and this also provides an alternative or 'outer' perspective to the modern (Western type of) societies. The book repeatedly hints at this, showing how the strange habitable places imaged by planetary scientists differ so radically from the way of life here on the Earth.

Messeri considers as her main contribution the deepening of our understanding of 'cultural connectivities between cosmic worlds', and where 'Earth becomes part of a vast interplanetary network'. Focusing on planetary scientists as the main target of her ethnographic study, she identifies and analyses the practices and techniques that allow them to transform planets from abstract objects in astronomical space into places full of meanings and considered from the point of view of (potential) human presence: "[P]lacemaking at a planetary scale resists homogeneity... [and] transforms the planetary from the perceived to the experienced. A place-based orientation, rather than passively gazing at the globe from the outside, allows for an imagination of being on/within/alongside, 
of experiencing, the planet" (p. 12). Her notion of 'planetary imagination' catches the core of this process, because it captures the "holistic conceptions that scientists have of the planets they study. The planetary imagination includes scientific understandings of the planet and conceptions of planetary pasts and futures, as well as notions of what it would be like to be on and live on other planets" (ibid.).

Messeri's basic achievement consists in identification, description, and analysis of several different activities, or techniques, of placemaking: narrating, mapping, visualizing, and inhabiting, used by scientists "to imagine themselves on other worlds" (p. 19). In her own words, narrating builds a rich story that connects Earth with another world; mapping and visualizing other planets translates the strange and unknown into the sensorially relatable; while inhabiting and forms of embodiment are tools of placemaking, employed even when the place being made is physically inaccessible. Each technique is presented in a separate chapter, so the four chapters constitute the structure of the book.

Based on her fieldwork at the Mars Desert Research Station (MDRS) in Utah (chapter 1, "Narrating Mars in Utah's Desert"), she reveals three different placemaking practices: 1) building 'informal maps and marked GPS waypoints'; 2) (geological) visualizations necessary for figuring out where researchers stay in place and in time; and finally 3) the very inhabiting of the MDRS and coping with its infrastructural hardships. She summarizes the life of planetary scientists at the MDRS as 'double exposure', where Earth and Mars, present and future, acquired data, and bodily experience of living at the MDRS merge. Here "the entire planet finds its materiality through the landscape and ordering narratives woven by participants" (p. 33). Using Tom Moylan's interpretation of Mannheim's notion of utopia as well as the notion of heterotopia (M. Foucault), she describes the MDRS as a utopian narrative comprising "stories of geologic history, the ideal of fieldwork, the frontier and the American West, and scientific and speculative stories" (p. 68). This general utopian narrative embraces four specific landscapes and related geological, astrogeological, areological, and science fiction narratives.

We find especially revealing her science fiction narrative behind the idea, architectural design, and the way of life of the MDRS habitat:

Just as the Utah desert made the most sense to Mars scientists once elements of Martian geology were present in the landscape, [the habitat] cylindrical living space makes complete sense when viewed through the lens of science fiction. For those who have spent decades reading about future colonies on Mars, it is a joy to bring those elements into the present. (p. 66)

Experienced anthropologists could find a strange parallel between a science fiction narrative describing Mars habitat, and classical anthropological texts, describing the worlds of the Bororo or Ewenki, where the mythological narrative exteriorizes in material culture and social life.

In chapter 2, "Mapping Mars in Silicon Valley", Lisa Messeri brings the reader to a small group of IT researchers called Mapmakers, who inhabit NASA Ames Research Centre in Silicon Valley. Established during one of the numerous restructurings of Ames and as a sign of its opening towards the public and business communities, the work of the group of Mapmakers indicates an important change in the exploration practices of planetary scientists. Using an open source code developed by NASA, they are aiming at the democratization of a huge amount of data accumulated from NASA's robotic missions on Mars. They produce interactive maps integrated in Microsoft and Google 
software, which depart from abstract and purely objective visualizations of traditional scientific maps, bringing into them the perspective of a living human body with its curiosity and meanings, where the local perspective dominates. Messeri skilfully traces the challenges and contradictions in this work since 'democratization' is embedded in the 'imperial strategy' of NASA as a government agency and presupposes an educated and curious public with basic IT-skills.

In chapter 3, "Visualizing Alien Worlds", and chapter 4, "Inhabiting Other Earths", the author expands the techniques and patterns of activities of planetary imagination she identified at the MDRS and Ames in the new settings - at the Massachusetts Institute of Technology (MIT) (exoplanet scientist Sara Seager), and at Cerro Tololo InterAmerican Observatory (CTIO) in Andes Mountains, Chile. However, unlike on Mars, in these new settings the scientific exploration based on new technology made a step that was almost unimaginable a few decades ago: now the planetary scientists were able to observe planets around distant stars many light years away from the Sun. They learned how to measure the orbit, size, mass, and chemical composition of the planets passing in front of these stars, thus causing miniscule changes in the spectrometric data.

This way an entirely new branch of planetary science - exoplanets, along with research groups studying them - emerged. Lisa Messeri is maybe the first anthropologist who carried out her fieldwork among these groups. Interestingly enough, she identifies the same basic pattern of placemaking, using different techniques and 'rhetoric':

For exoplanet astronomers, a planetary imagination helps make worlds as meaningful as an intimate, local place. This is a difficult task requiring a rich imaginary. Without high-resolution pictures of the planet, like those we have for Mars, exoplanet astronomers produce abstract representations... [...] Yet these images do not obviously represent places but are made into places through the social and technical practices around which this new scientific community has coalesced. In constructing and discussing visualizations, astronomers engage simultaneously in practices of professionalization and of place-making. (p. 118)

The group of MIT focuses on exoplanets whose characteristics sometimes substantially differ from the planets in the solar system. The author had a rare "privilege of observing the community at a time when the techniques of seeing were still being developed", discovering unique semiotic, rhetoric, and perceptional patterns summarized as three different "modes of seeing" - "seeing with the system", "seeing beyond the signal", and "seeing through language". In search of concepts to frame her findings she found useful resources in the works of anthropologist Ch. Goodwin, psychologists D. Gentner and M. Jeziorski, sociologists of science like M. Lynch, S. Woolgar, B. Latour, A. Cambrosio, M. Hesse, M. Kemp, and some others (pp. 119-123).

Lisa Messeri completes her anthropological study of placemaking practices in planetary science by returning to the notion of 'inhabiting'. The group of exoplanet astronomers at the CTIO is chasing a particular type of planets - those resembling the conditions on Earth and where humans could potentially live. Similar to the MDRS, this is another unique object of anthropological study, whose job is to identify the most distant places suitable for inhabiting, thus setting the directions in which our "grand-grandgrandchildren will direct their ships". Oscillating between Heidegger's notion of 'dwelling' and Doreen Massey's 'fluid' notion of home, relevant to the 21th-century waves of migration, the exoplanet astronomers search for a "perfect Earth-like planet" and at the 
same time are "entrenched in ideas of unboundedness, multiplicity, flows, and networks... never about a single world but about the potential for all planets to be worlds" (p. 187).

We would like to end our review with a critical note. Lisa Messeri considers 'exploration' as a bound to classical modern type of colonization, i.e., as a preparatory step to industrial, political, or military expansion. This refers to anthropology itself, which also emerged as a tool of colonial powers to cope with the local population. Latour's anthropological notion of 'centres of calculation' also describes this type of modern science, in which with each circle of going to the 'field' and coming back to the centre with new data, the asymmetry between the metropole and periphery increases, and the centre becomes stronger than the locals. However, late modern, 21st-century relations between science and power substitutably change, as reflected in the notions of 'science in wild' and 'hybrid forum', describing situations when scientists are not superior to the public, but have to take it as an agent who has enough capacity to enter into dialogue and start collaboration with them (Callon \& Lascoumes \& Barthe 2009). This and other studies have questioned the distinction between laymen and experts, and pointed to the fact that in contemporary societies the share of population between 25-64 years of age with university education is well above $30 \%$, and in some societies even $50 \%$ (https:// en.wikipedia.org/wiki/List_of_countries_by_tertiary_education_attainment). This means that scientific knowledge and scientific instruments are not anymore the privilege of a handful of people in aristocratic courts and the Academy of Sciences, like it was in the 18th century. Hence it is possible that exploration may serve as a new, 'non-imperial' type of colonization carried out by communities and similar to the colonization of the Pacific by Polynesians, Ancient Greek colonies, and even the colonization of Quakers and Puritans in America. 'Mars Underground' and 'Mars Society' movements that Messeri mentions in her books, or David Valentine's ethnography of New Space entrepreneurs seeking colonization of space in a way 'orthogonal to profit' support such an option. Maybe this is one of the reasons why 'frontier' metaphor is so popular among space explorers.

\section{Acknowledgements}

Written within the framework of the project "Man in a Changing World: Problems of Identity and Social Adaptation in History and at Present" (the RF Government grant No. 14.B25.31.0009, PI D.A. Funk).

Irina Popravko, Tomsk State University

Ivan Tchalakov, University of Plovdiv 'Paisii Hilendarski' / Tomsk State University

\section{References}

Callon, Michel \& Lascoumes, Pierre \& Barthe, Yannick 2009. Acting in an Uncertain World. Cambridge, MA: MIT Press.

Latour, Bruno 2005. Reassembling the Social: An Introduction to Actor-Network-Theory. Oxford: Oxford University Press.

Valentine, David 2012. Exit Strategy: Profit, Cosmology, and the Future of Humans in Space. Anthropological Quarterly, Vol. 85, No. 4, pp. 1045-1067. http://dx.doi. org/10.1353/anq.2012.0073.

Valentine, David \& Olson, Valerie A. \& Battaglia, Debbora 2009. Encountering the Future: Anthropology and Outer Space. Anthropology News, Vol. 50, No. 9, pp. 11-15. http://dx.doi.org/10.1111/j.1556-3502.2009.50911.x. 


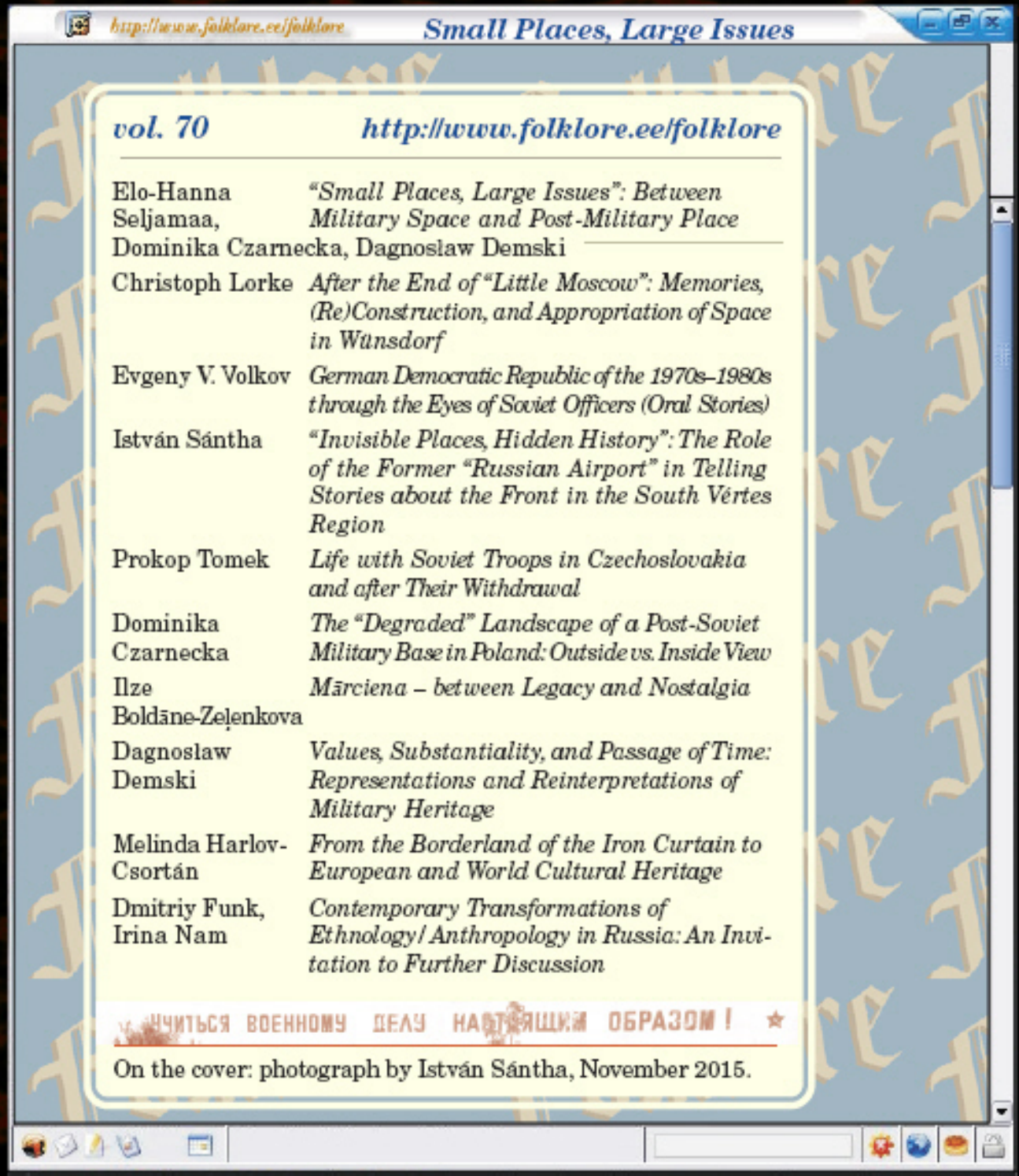

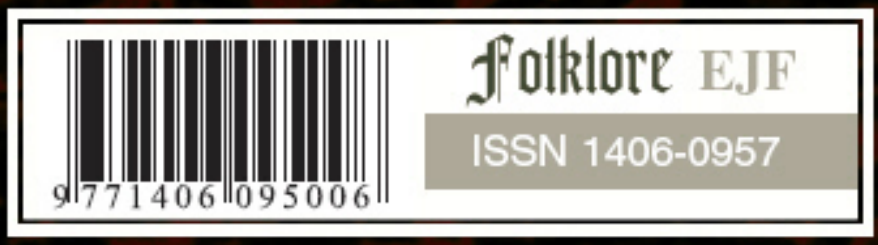

